\title{
Investigation of the Effects of Make-up Air on Atrium Smoke Conditions
}

\author{
by
}

Amir Rafinazari

A thesis submitted to the Faculty of Graduate and Postdoctoral Affairs in partial fulfillment of the requirements for the degree of

Doctor of Philosophy

in

Civil Engineering

Carleton University

Ottawa, Ontario

(C) 2015, Amir Rafinazari 


\begin{abstract}
An atrium creates an attractive environment in luxurious buildings, shopping centers and prestigious hotels. Most atria have a large space, designed to provide a visual and special appeal. One of the main concerns in designing an atrium is related to fire safety and smoke movement thorough the atrium in the event of fire. As the atrium interconnects several floors, the smoke layer may descend to a level that endangers occupants on upper floors.
\end{abstract}

Protecting people from the adverse effects of smoke in the event of fire is a major concern of building codes. There are several guidelines available regarding the design of smoke management systems in atria such as NFPA 92B and the ASHRAE/SFPE publication, Handbook of Smoke Control Engineering. In this study, in addition to running full-scale tests of atrium fires, CFD modelling has been conducted to investigate the effects of make-up air on the smoke layer height including the effects of make-up air velocity, opening arrangement and air flow direction.

A reduction factor correlation is proposed based on the results of full-scale experiments to consider the impact of make-up air velocity, opening arrangement and air flow direction on the smoke layer height in an atrium equipped with mechanical smoke management system. 


\section{Dedication}

I would like to dedicate this dissertation to my grandmother, Mohtaram Oushak Saraei, who always supported and encouraged me throughout my life. 


\section{Acknowledgments}

I would like to express my gratitude to Prof. George V. Hadjisophocleous for his supervision of this research and for his continued support, generous advice and patience throughout this research project.

I would also like to thank Dr. Jim Mehaffey for his valuable advice and guidance.

I would like to sincerely acknowledge Mr. Ba Lamthien for his help and technical advice in conducting the experiments. The NRC staff at the National Fire Laboratory is acknowledged for their kind help during the experiments.

Thanks to the faculty of Civil Engineering Department and Fire Safety Engineering Program for all of their help and advice throughout my study.

Lastly, a warm appreciation is given to my family for their support and encouragement throughout my studies. 


\section{Table of Contents}

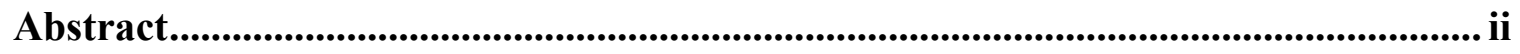

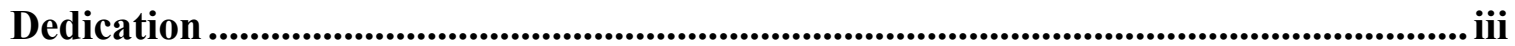

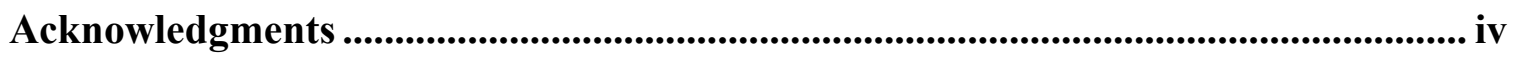

Table of Contents ...................................................................................................................... v v

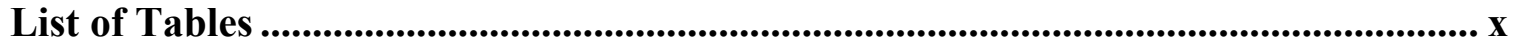

List of Figures.............................................................................................................................. xiv

List of Symbols .......................................................................................................

Chapter 1: Introduction ....................................................................................................... 1

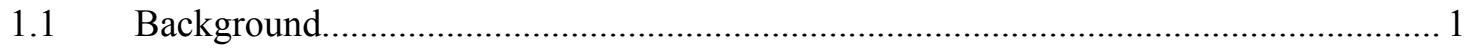

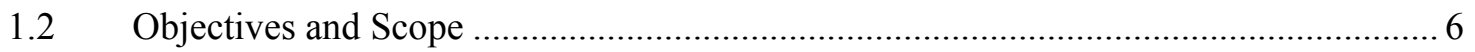

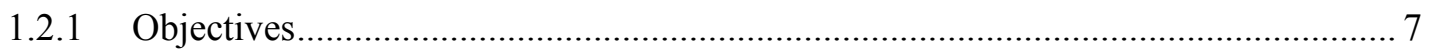

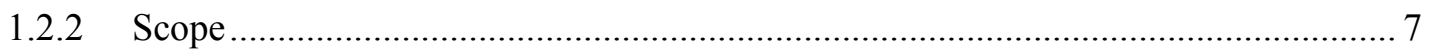

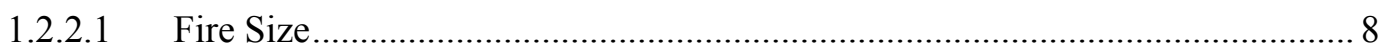

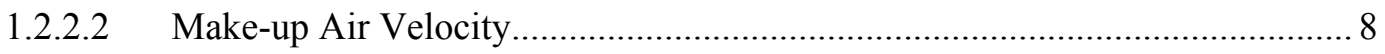

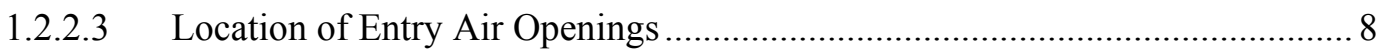

1.2.2.4 Fire Location Relative to Wall Opening.......................................................

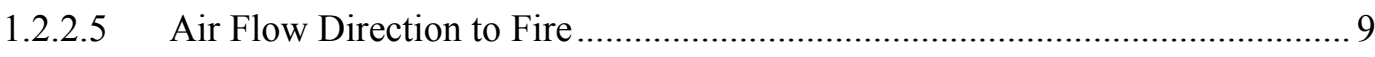

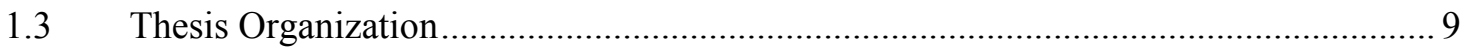

Chapter 2: Literature Review ............................................................................ 11

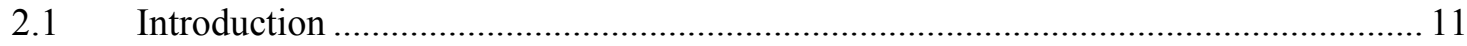

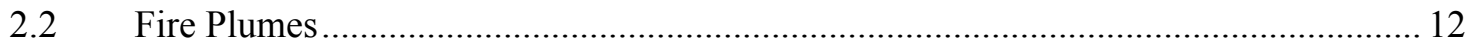

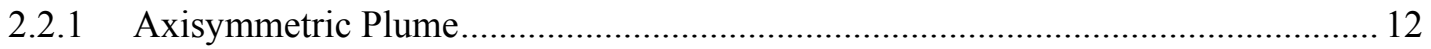

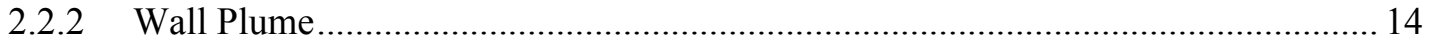




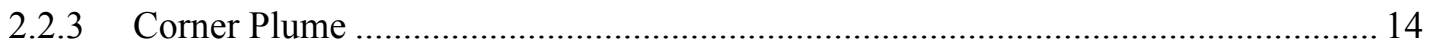

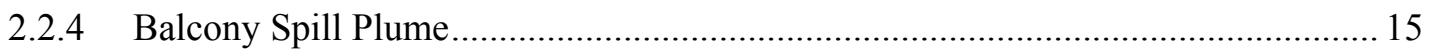

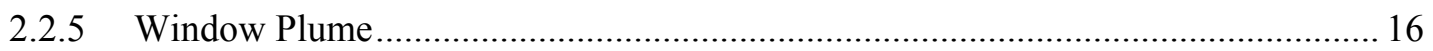

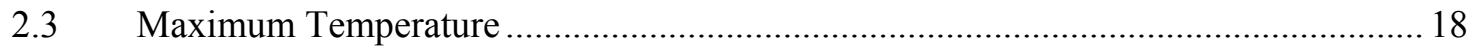

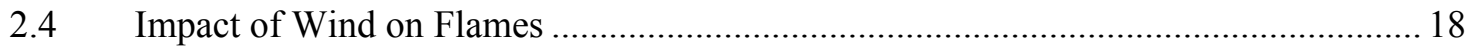

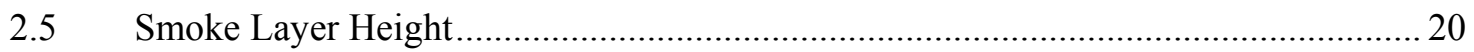

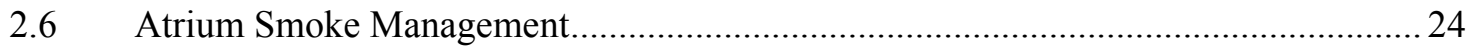

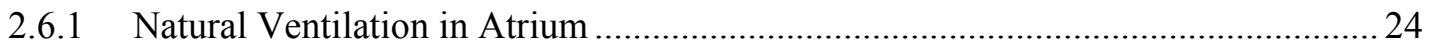

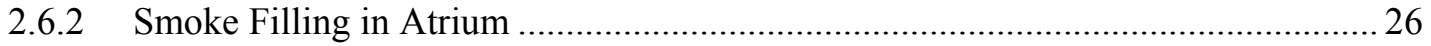

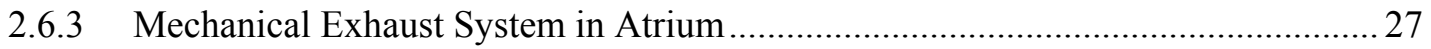

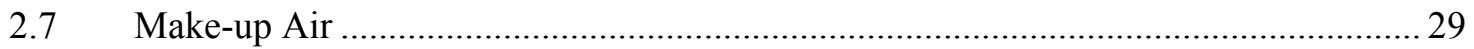

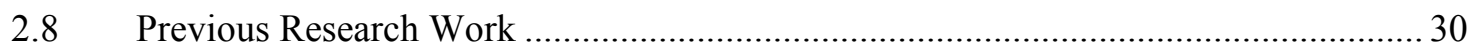

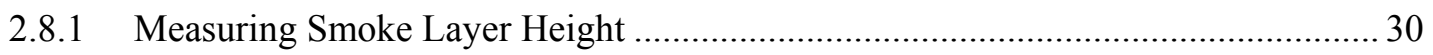

2.8.2 Effects of Make-up Air Velocity and Opening Arrangement ................................. 32

2.8.3 Effects of Make-up Air Velocity and Opening Arrangement ................................. 40

Chapter 3: Full-Scale Experiments ........................................................................................ 42

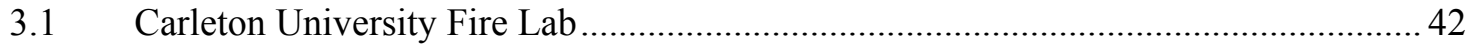

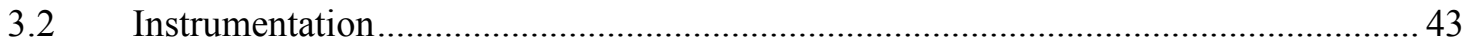

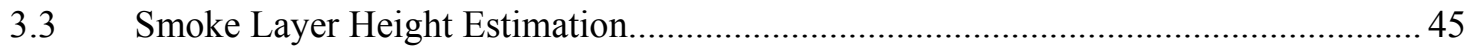

3.3.1 Smoke Layer Height Estimation Using Correlations .......................................... 45

3.3.2 Smoke Height Measuring Method in Experiments ............................................... 46

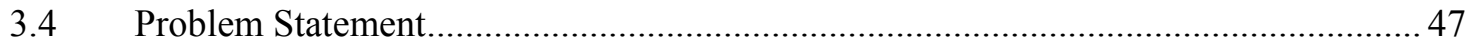

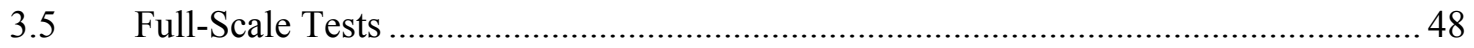

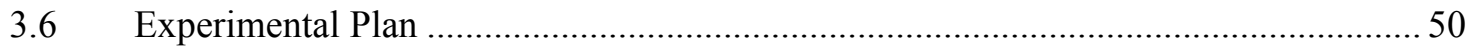

Chapter 4: Modelling.................................................................................................... 55

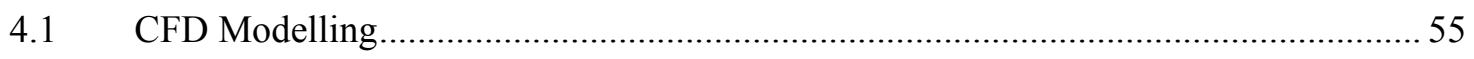




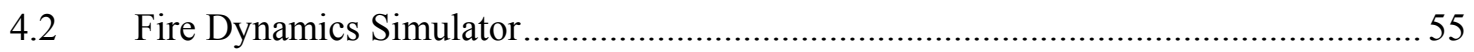

4.3 Numerical Method for Determining Interface Height: .......................................... 58

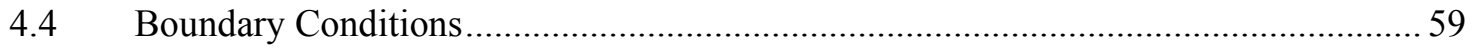

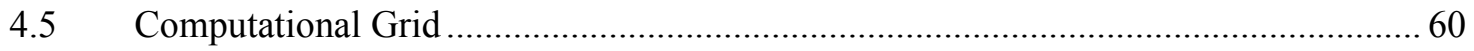

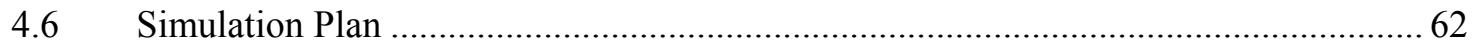

Chapter 5: Effects of Make-up Air Velocity on Atrium Smoke Conditions ............. 63

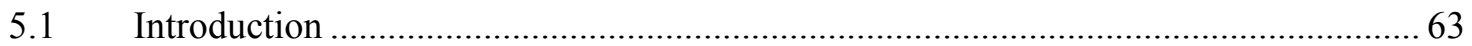

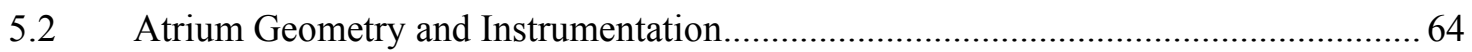

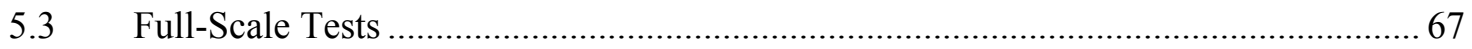

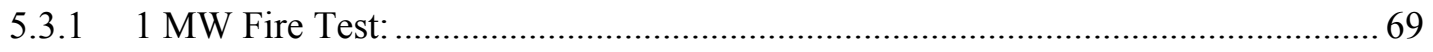

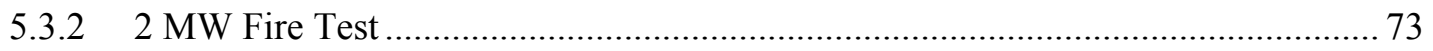

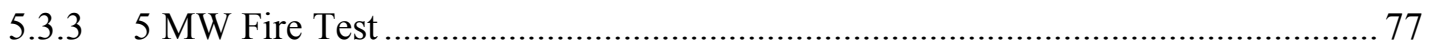

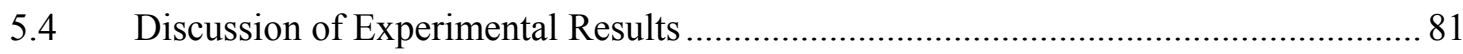

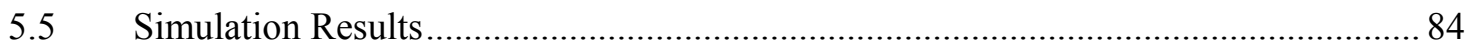

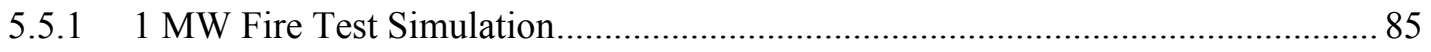

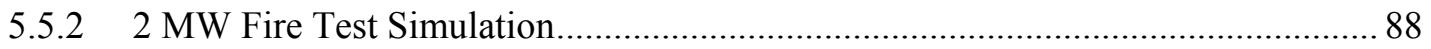

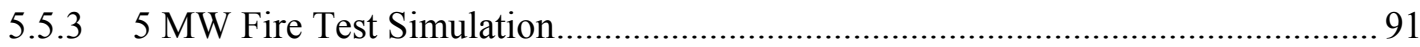

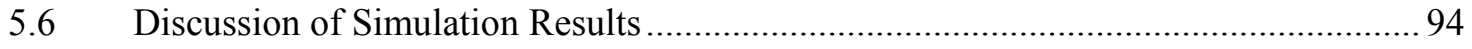

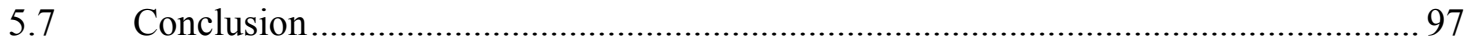

Chapter 6: Effects of Opening Arrangement on Atrium Smoke Conditions............ 99

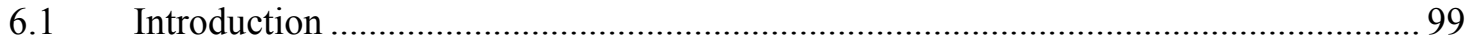

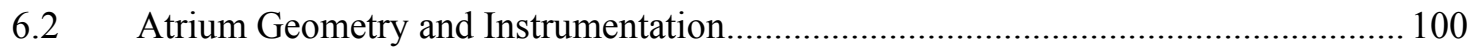

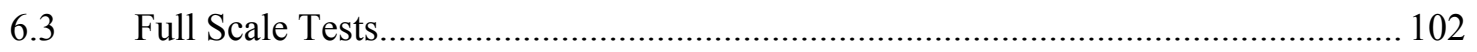

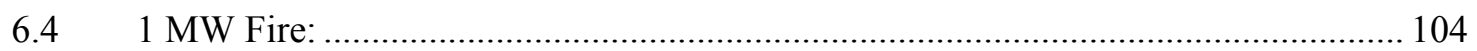

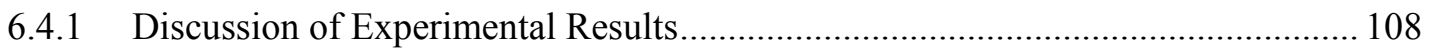

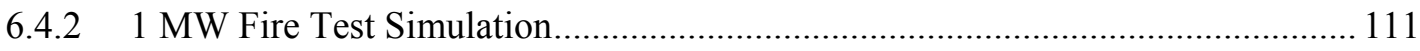




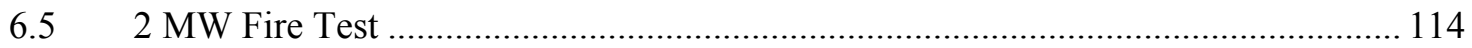

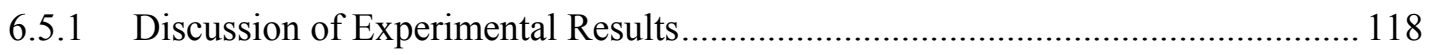

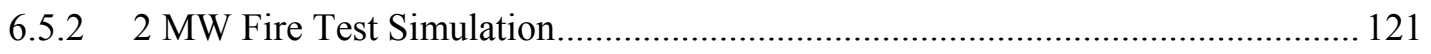

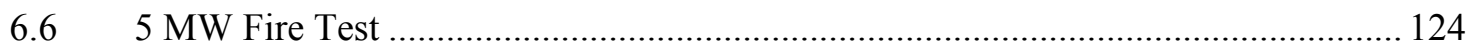

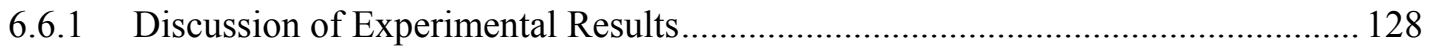

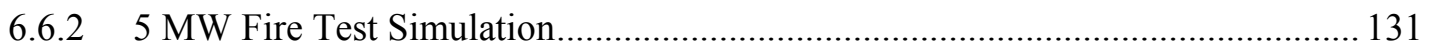

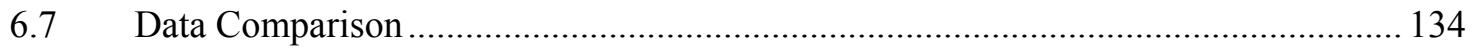

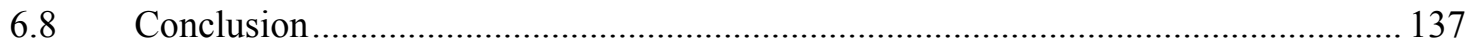

Chapter 7: Effects of Air Flow Direction on Atrium Smoke Conditions ................ 148

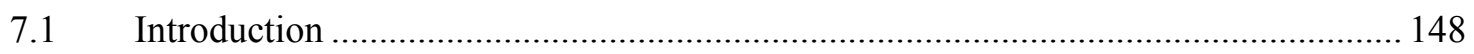

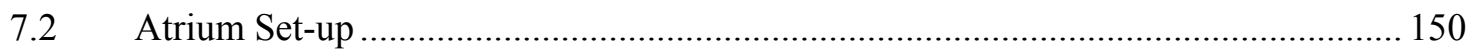

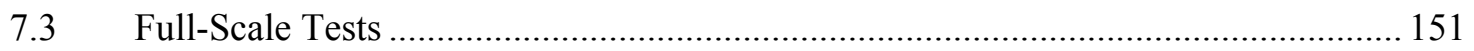

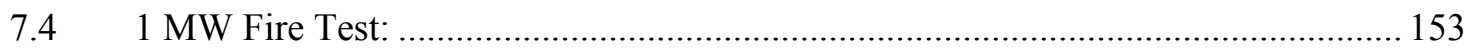

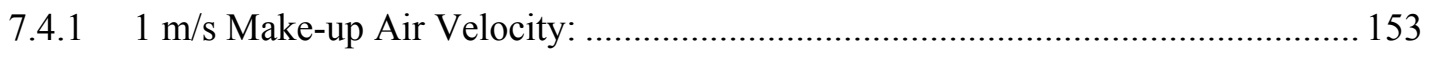

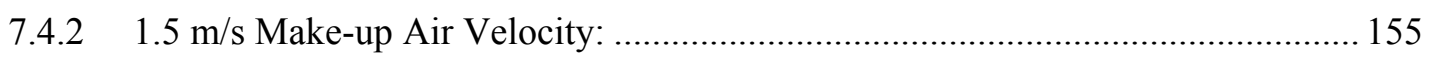

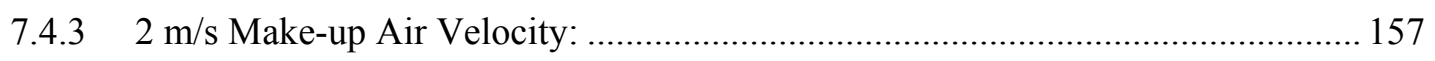

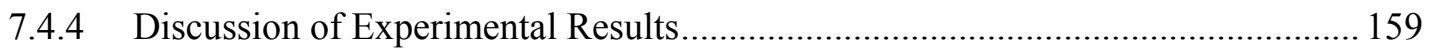

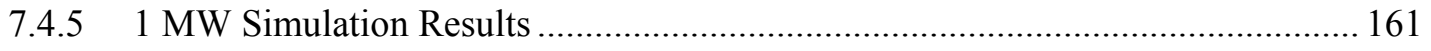

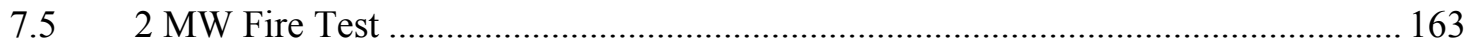

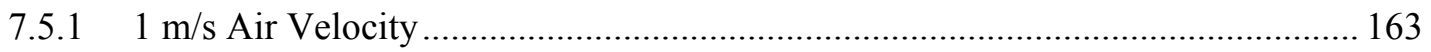

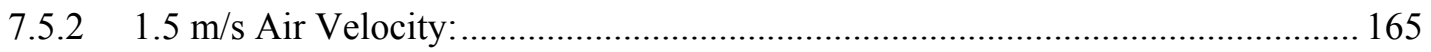

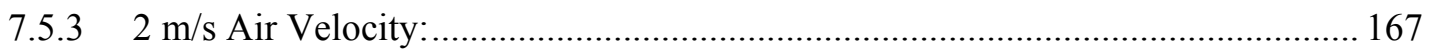

7.5.4 Discussion of 2 MW Fire Experimental Results ................................................... 169

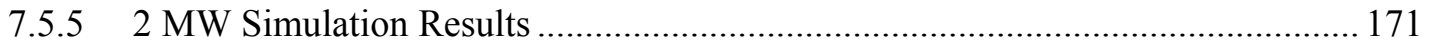

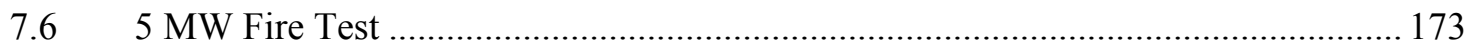

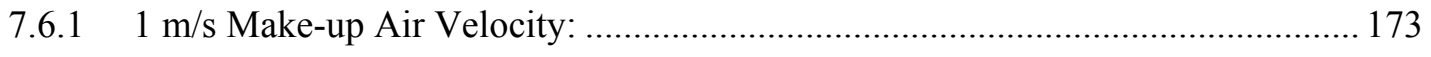




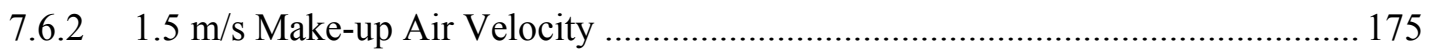

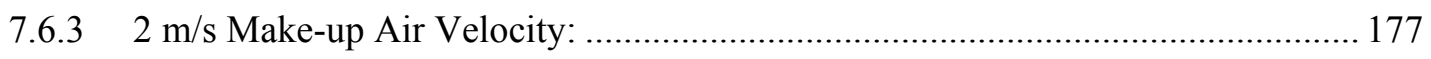

7.6.4 Discussion of 5 MW Fire Test Results.............................................................. 179

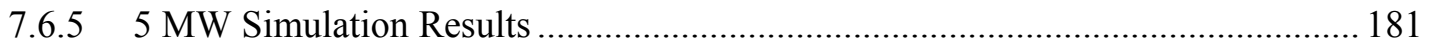

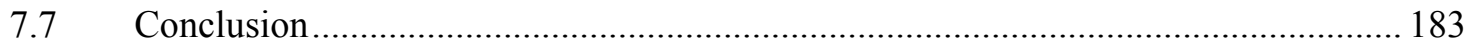

Chapter 8: Design Guidelines ............................................................................................. 190

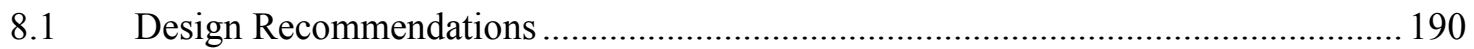

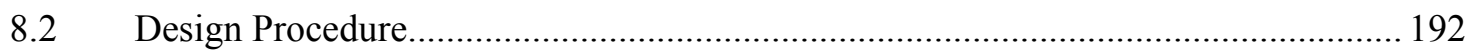

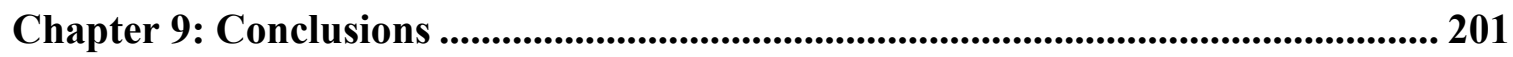

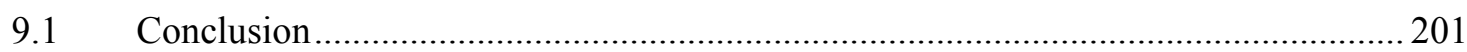

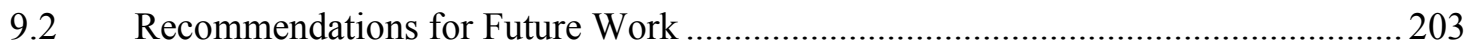

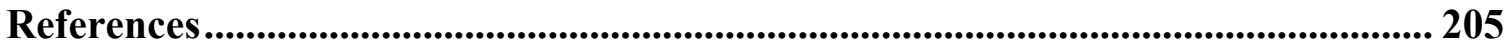




\section{List of Tables}

Table 3-1 Mass flow rates and required areas for a velocity of $1 \mathrm{~m} / \mathrm{s}$ and an opening

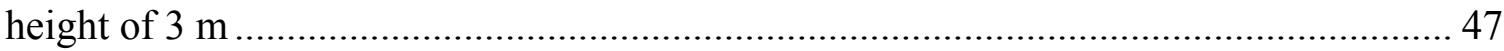

Table 3-2 Variables involved and potential values........................................................ 51

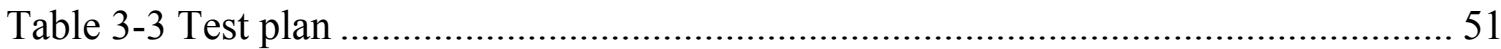

Table 4-1 Effect of computational grid size on the simulation results ............................ 62

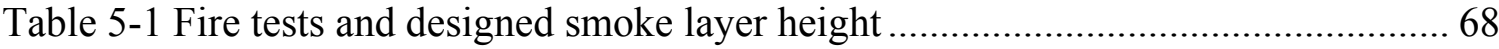

Table 5-2 Smoke layer height at different points in $1 \mathrm{MW}$ fire tests .............................. 72

Table 5-3 Smoke layer height at different points in $2 \mathrm{MW}$ fire tests ............................. 76

Table 5-4 Smoke layer height at different points in $5 \mathrm{MW}$ fire tests .............................. 80

Table 5-5 The effect of make-up air velocity on smoke layer height in 1 MW fire test .. 81

Table 5-6 The effect of make-up air velocity on smoke layer height in 2 MW fire test .. 82

Table 5-7 The effect of make-up air velocity on smoke layer height in 5 MW fire test .. 83

Table 5-8 Smoke layer height at different points in CFD modelling of 1 MW fire tests. 86

Table 5-9 Smoke layer height at different points in CFD modelling of 2 MW fire tests. 89

Table 5-10 Smoke layer height at different points in CFD modelling of 5 MW fire tests 92

Table 5-11 The effect of make-up air velocity on smoke layer height in modelling of 1

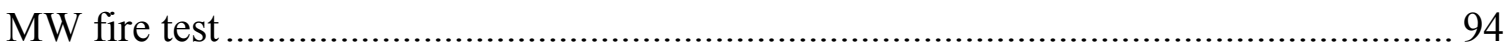

Table 5-12 The effect of make-up air velocity on smoke layer height in modelling of 2

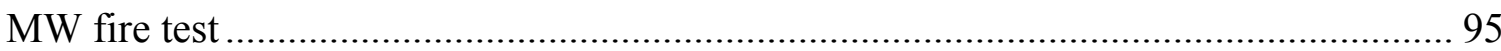

Table 5-13 The effect of make-up air velocity on smoke layer height in modelling of 5

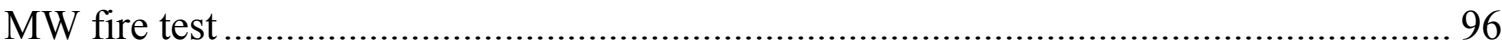


Table 6-1 Test characteristics for the $1 \mathrm{MW}$ fire exposed to different opening arrangement.

Table 6-2 Smoke Layer height in the $1 \mathrm{MW}$ fire test exposed to different opening arrangement.

Table 6-3 Smoke layer height from CFD modelling of the $1 \mathrm{MW}$ fire test exposed to different opening arrangement

Table 6-4 Test characteristics for the $2 \mathrm{MW}$ fire exposed to different opening arrangement.

Table 6-5 Smoke Layer height in the 2 MW fire test exposed to different opening arrangement.

Table 6-6 Smoke layer height from CFD modelling of the $2 \mathrm{MW}$ fire test exposed to different opening arrangement

Table 6-7 Test characteristics for the $5 \mathrm{MW}$ fire exposed to different opening arrangement.

Table 6-8 Smoke Layer height in the 5 MW fire test exposed to different opening arrangement.

Table 6-9 Smoke layer height from CFD modelling of the $5 \mathrm{MW}$ fire test exposed to different opening arrangement Table 6-10 Standard error of the proposed correlation in the case of symmetric opening arrangement 143

Table 6-11 Standard error of the proposed correlation in the case of asymmetric opening arrangement 
Table 7-1 Test characteristics for the $1 \mathrm{MW}$ fire exposed to the $1 \mathrm{~m} / \mathrm{s}$ rotational make-up air velocity 153

Table 7-2 Test characteristics for the $1 \mathrm{MW}$ fire exposed to the $1.5 \mathrm{~m} / \mathrm{s}$ rotational makeup air velocity 155

Table 7-3 Test characteristics for the $1 \mathrm{MW}$ fire exposed to the $2 \mathrm{~m} / \mathrm{s}$ rotational make-up air velocity 157

Table 7-4 Smoke layer height in the $1 \mathrm{MW}$ fire test exposed to different air flow

directions 160

Table 7-5 Smoke layer height from CFD modelling of the $1 \mathrm{MW}$ fire test exposed to different air flow directions 162

Table 7-6 Test characteristics for the $2 \mathrm{MW}$ fire exposed to the $1 \mathrm{~m} / \mathrm{s}$ rotational make-up air velocity 163

Table 7-7 Test characteristics for the $2 \mathrm{MW}$ fire exposed to the $1.5 \mathrm{~m} / \mathrm{s}$ rotational makeup air velocity 165 Table 7-8 Test characteristics for the $2 \mathrm{MW}$ fire exposed to the $2 \mathrm{~m} / \mathrm{s}$ rotational make-up air velocity 167

Table 7-9 Smoke layer height in the 2 MW fire test exposed to different air flow directions 170

Table 7-10 Smoke layer height from CFD modelling of the $2 \mathrm{MW}$ fire test exposed to different air flow directions 172 Table 7-11 Test characteristics for the $5 \mathrm{MW}$ fire exposed to the $1 \mathrm{~m} / \mathrm{s}$ rotational make-up air velocity 173 
Table 7-12 Test characteristics for the $5 \mathrm{MW}$ fire exposed to the $1.5 \mathrm{~m} / \mathrm{s}$ rotational make-

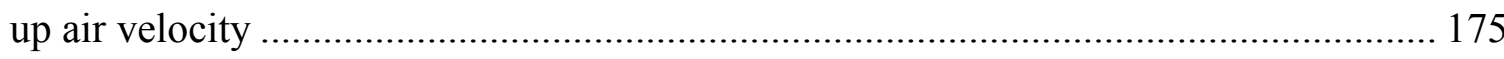

Table 7-13 Test characteristics for the $5 \mathrm{MW}$ fire exposed to the $2 \mathrm{~m} / \mathrm{s}$ rotational make-up

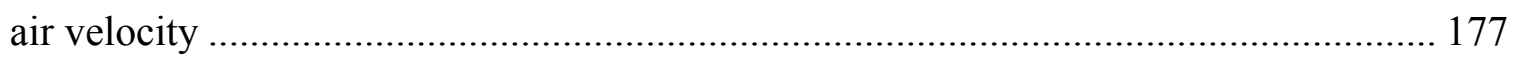

Table 7-14 Smoke layer height in the $5 \mathrm{MW}$ fire test exposed to different air flow

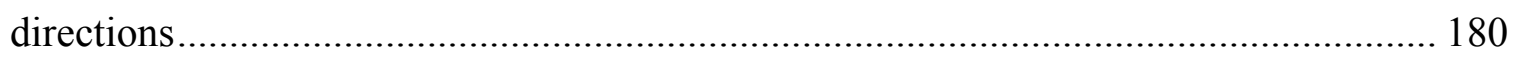

Table 7-15 Smoke layer height from CFD modelling of the $5 \mathrm{MW}$ fire test exposed to different air flow directions .......................................................................... 182

Table 7-16 Standard error of the proposed correlation in the case of rotational air flow189 


\section{List of Figures}

Figure 1-1 Intended operation of smoke management system [modified from Lougheed,

G. D. (2000)]

Figure 1-2 Air stream impact destroys plume and exposes occupants to smoke [modified

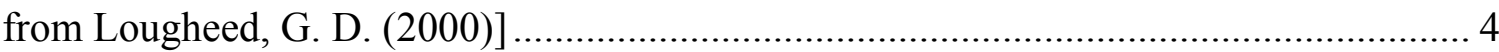

Figure 1-3 Inlet air does not affect plume in the case of low make-up air velocity [Kerber,

S. and Milke, J. A. (2007)]

Figure 1-4 Inlet air spreads products of combustion throughout atrium space in the case of high make-air velocity [Kerber, S. and Milke, J. A. (2007)]....................................... 5

Figure 2-1 Schematic diagram of an axisymmetric plume ……………….................... 17

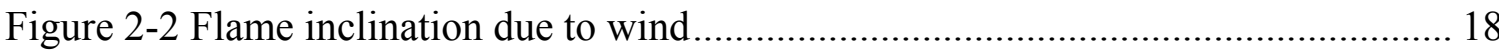

Figure 2-3 Clear height with steady fire [modified from Lougheed, G. D. (2000)] ........ 21

Figure 2-4 Natural venting in an atrium [modified from Lougheed, G. D. (2000)] ......... 25

Figure 2-5 Schematic diagram of two zone model ...................................................... 26

Figure 2-6 Mechanical smoke exhaust [modified from Lougheed, G. D. (2000)] ........... 28

Figure 3-1 Photo of Carleton University facility ............................................................ 43

Figure 3-2 Location of thermocouple trees in the atrium ............................................... 44

Figure 3-3 Data recording equipment in Carleton University Fire Lab............................. 44

Figure 3-4 Carleton University equipped atrium for fire tests........................................ 45

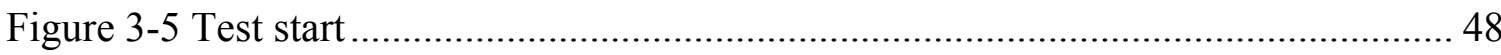

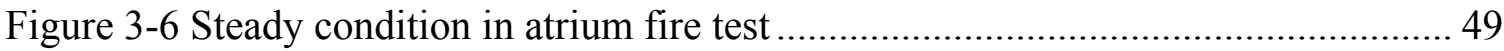

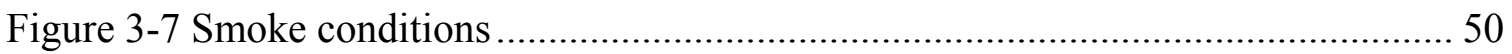

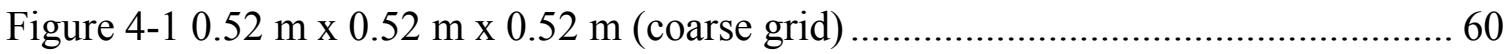




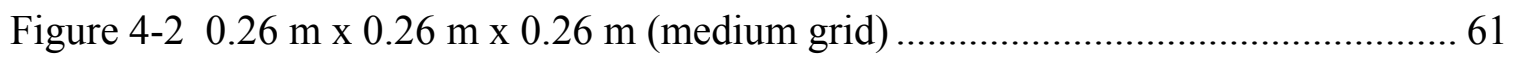

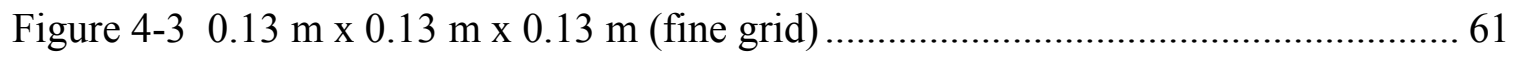

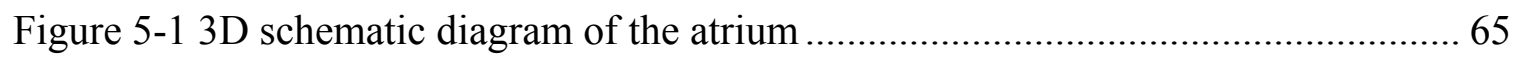

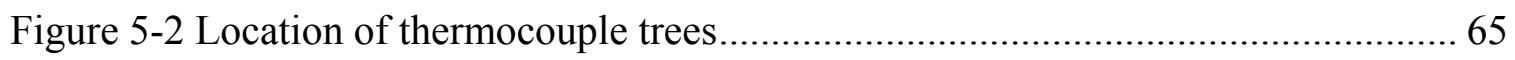

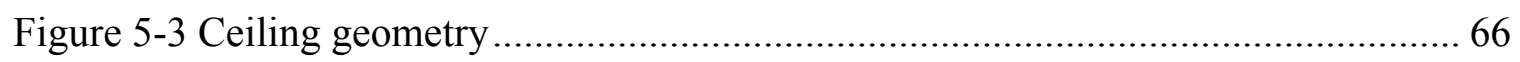

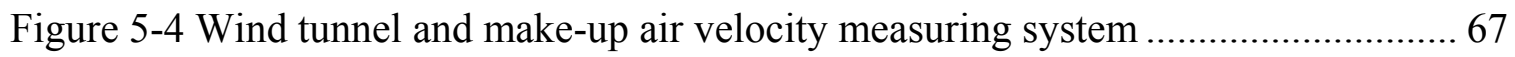

Figure 5-5 Temperature variation for the $1 \mathrm{MW}$ fire test ...................................... 70

Figure 5-6 Vertical temperature profiles for the $1 \mathrm{MW}$ fire test................................ 70

Figure 5-7 Hot layer, cold layer and interface temperature for the $1 \mathrm{MW}$ fire test......... 71

Figure 5-8 Temperature variation for the $2 \mathrm{MW}$ fire test ...................................... 73

Figure 5-9 Vertical temperature profiles for the $2 \mathrm{MW}$ fire test................................. 74

Figure 5-10 Hot layer, cold layer and interface temperature for the $2 \mathrm{MW}$ fire test ....... 75

Figure 5-11 Temperature variation for the $5 \mathrm{MW}$ fire test ...................................... 77

Figure 5-12 Vertical temperature profiles for the $5 \mathrm{MW}$ fire test.............................. 78

Figure 5-13 Hot layer, cold layer and interface temperature for the $5 \mathrm{MW}$ fire test ....... 79

Figure 5-14 Normalized smoke layer height in $1 \mathrm{MW}$ fire test................................ 81

Figure 5-15 Normalized smoke layer height in $2 \mathrm{MW}$ fire test ................................. 82

Figure 5-16 Normalized smoke layer height in $5 \mathrm{MW}$ fire test................................. 83

Figure 5-17 Predicted temperature contours for the $1 \mathrm{MW}$ fire on a vertical plane through

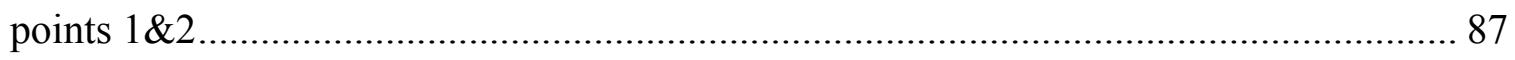

Figure 5-18 Predicted temperature contours for the $2 \mathrm{MW}$ fire on a vertical plane through

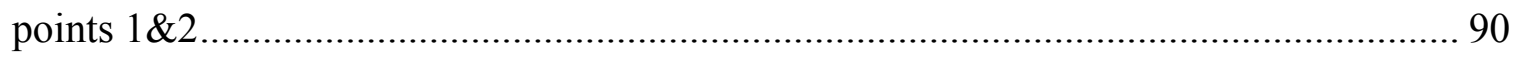


Figure 5-19 Predicted temperature contours for the $5 \mathrm{MW}$ fire on a vertical plane through

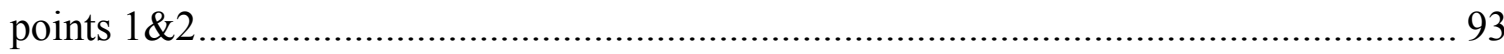

Figure 5-20 Normalized smoke layer height in CFD modelling of 1 MW fire test.......... 94 Figure 5-21 Normalized smoke layer height in CFD modelling of 2 MW fire test......... 95 Figure 5-22 Normalized smoke layer height in CFD modelling of 5 MW fire test......... 96 Figure 5-23 Comparison of smoke layer height prediction methods............................ 98

Figure 6-1 Schematic possible locations of openings ............................................ 99

Figure 6-2 Effect of opening arrangement on smoke layer height in CFD modeling

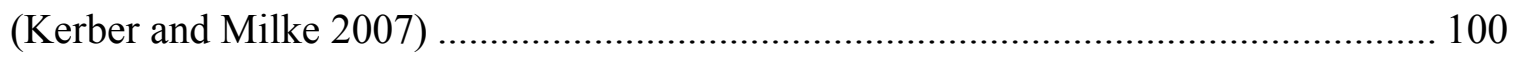

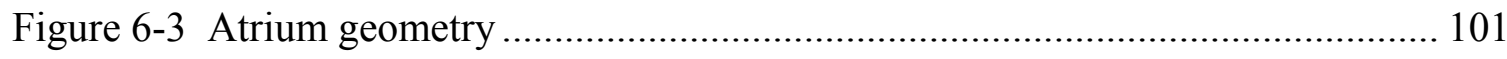

Figure 6-4 Atrium fire test ........................................................................... 102

Figure 6-5 Vertical temperature profile for the $1 \mathrm{MW}$ fire test exposed to $1 \mathrm{~m} / \mathrm{s}$ air

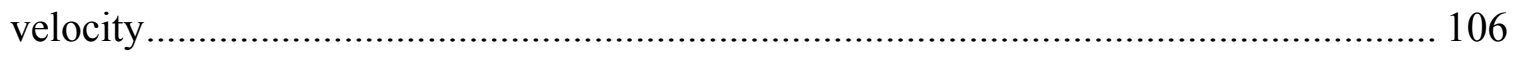
Figure 6-6 Vertical temperature profile for the $1 \mathrm{MW}$ fire test exposed to $1.5 \mathrm{~m} / \mathrm{s}$ air

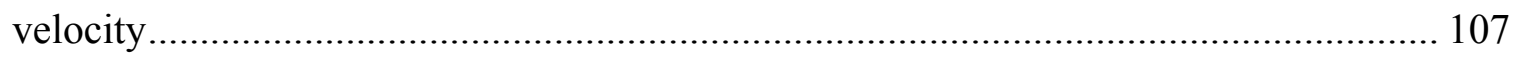
Figure 6-7 Vertical temperature profile for the $1 \mathrm{MW}$ fire test exposed to $2 \mathrm{~m} / \mathrm{s}$ air velocity.

Figure 6-8 Smoke Layer height in the $1 \mathrm{MW}$ fire test exposed to different opening

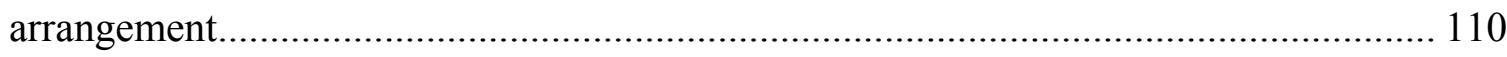
Figure 6-9 Smoke layer height from CFD modelling of the $1 \mathrm{MW}$ fire test exposed to

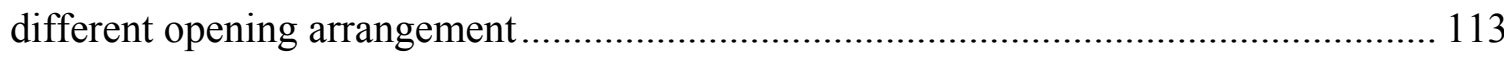

Figure 6-10 Vertical temperature profile for the $2 \mathrm{MW}$ fire test exposed to $1 \mathrm{~m} / \mathrm{s}$ air velocity. 116 
Figure 6-11 Vertical temperature profile for the $2 \mathrm{MW}$ fire test exposed to $1.5 \mathrm{~m} / \mathrm{s}$ air velocity.

Figure 6-12 Vertical temperature profile for the $2 \mathrm{MW}$ fire test exposed to $2 \mathrm{~m} / \mathrm{s}$ air velocity.

Figure 6-13 Smoke Layer height in the $2 \mathrm{MW}$ fire test exposed to different opening arrangement.

Figure 6-14 Smoke layer height from CFD modelling of the $2 \mathrm{MW}$ fire test exposed to different opening arrangement

Figure 6-15 Vertical temperature profile for the $5 \mathrm{MW}$ fire test exposed to $1 \mathrm{~m} / \mathrm{s}$ air velocity.

Figure 6-16 Vertical temperature profile for the $5 \mathrm{MW}$ fire test exposed to $1.5 \mathrm{~m} / \mathrm{s}$ air velocity.

Figure 6-17 Vertical temperature profile for the $5 \mathrm{MW}$ fire test exposed to $2 \mathrm{~m} / \mathrm{s}$ air velocity.

Figure 6-18 Smoke layer height in the $5 \mathrm{MW}$ fire test exposed to different opening arrangement

Figure 6-19 Smoke layer height from CFD modelling of the $5 \mathrm{MW}$ fire test exposed to different opening arrangement 133 Figure 6-20 Comparison of smoke layer height with the correlations estimation for the 1 MW fire. 135 Figure 6-21 Comparison of smoke layer height with the correlations estimation for the 2 MW fire. 136 
Figure 6-22 Comparison of smoke layer height with the correlations estimation for the 5

MW fire 136

Figure 6-23 Comparison of smoke layer height for the $1 \mathrm{MW}$ fire 138

Figure 6-24 Comparison of smoke layer height for the $2 \mathrm{MW}$ fire

Figure 6-25 Comparison of smoke layer height for the $5 \mathrm{MW}$ fire

Figure 6-26 Proposed reduction factor correlation for the $1 \mathrm{MW}$ fire with symmetric opening arrangement

Figure 6-27 Proposed reduction factor correlation for the $2 \mathrm{MW}$ fire with symmetric opening arrangement

Figure 6-28 Proposed reduction factor correlation for the $5 \mathrm{MW}$ fire with symmetric opening arrangement

Figure 6-29 Proposed reduction factor correlation for the $1 \mathrm{MW}$ fire with asymmetric opening arrangement 145

Figure 6-30 Proposed reduction factor correlation for the $2 \mathrm{MW}$ fire with asymmetric opening arrangement.

Figure 6-31 Proposed reduction factor correlation for the $5 \mathrm{MW}$ fire with asymmetric opening arrangement. 146

Figure 7-1 Effect of rotational make-up air on smoke layer height in CFD modeling [Kerber, S. and Milke, J. A. (2007)] 149

Figure 7-2 Atrium geometry for direct air flow test 150

Figure 7-3 Atrium geometry for rotational make-up air test 151

Figure 7-4 Rotational make-up air test in the atrium 152

Figure 7-5 Blocking wall to orient the air flow in the atrium 152 
Figure 7-6 Vertical temperature profile for the $1 \mathrm{MW}$ fire test exposed to the $1 \mathrm{~m} / \mathrm{s}$ rotational make-up air velocity

Figure 7-7 Vertical temperature profile for the $1 \mathrm{MW}$ fire test exposed to the $1.5 \mathrm{~m} / \mathrm{s}$ rotational make-up air velocity

Figure 7-8 Vertical temperature profile for the $1 \mathrm{MW}$ fire test exposed to the $2 \mathrm{~m} / \mathrm{s}$ rotational make-up air velocity 158

Figure 7-9 Smoke Layer height in the $1 \mathrm{MW}$ fire test exposed to different air flow directions 160 Figure 7-10 Smoke layer height from CFD modelling of the $1 \mathrm{MW}$ fire test exposed to different air flow directions 162

Figure 7-11 Vertical temperature profile for the $2 \mathrm{MW}$ fire test exposed to the $1 \mathrm{~m} / \mathrm{s}$ rotational make-up air velocity

Figure 7-12 Vertical temperature profile for the $2 \mathrm{MW}$ fire test exposed to the $1.5 \mathrm{~m} / \mathrm{s}$ rotational make-up air velocity 166

Figure 7-13 Vertical temperature profile for the $2 \mathrm{MW}$ fire test exposed to the $2 \mathrm{~m} / \mathrm{s}$ rotational make-up air velocity 168

Figure 7-14 Smoke Layer height in the $2 \mathrm{MW}$ fire test exposed to different air flow directions 170 Figure 7-15 Smoke layer height from CFD modelling of the $2 \mathrm{MW}$ fire test exposed to different air flow directions 172 Figure 7-16 Vertical temperature profile for the $5 \mathrm{MW}$ fire test exposed to the $1 \mathrm{~m} / \mathrm{s}$ rotational make-up air velocity 174 
Figure 7-17 Vertical temperature profile for the $5 \mathrm{MW}$ fire test exposed to the $1.5 \mathrm{~m} / \mathrm{s}$ rotational make-up air velocity 176

Figure 7-18 Vertical temperature profile for the $5 \mathrm{MW}$ fire test exposed to the $2 \mathrm{~m} / \mathrm{s}$ rotational make-up air velocity 178

Figure 7-19 Smoke layer height in the $5 \mathrm{MW}$ fire test exposed to different air flow directions 180

Figure 7-20 Smoke layer height from CFD modelling of the $5 \mathrm{MW}$ fire test exposed to different air flow directions 182

Figure 7-21 Comparison of smoke layer height for the $1 \mathrm{MW}$ fire 183

Figure 7-22 Comparison of smoke layer height for the $2 \mathrm{MW}$ fire 184 Figure 7-23 Comparison of smoke layer height for the $5 \mathrm{MW}$ fire 184 Figure 7-24 Proposed reduction factor correlation for the $1 \mathrm{MW}$ fire exposed to rotational make-up air 187 Figure 7-25 Proposed reduction factor correlation for the $2 \mathrm{MW}$ fire exposed to rotational make-up air 187

Figure 7-26 Proposed reduction factor correlation for the $5 \mathrm{MW}$ fire exposed to rotational make-up air 188

Figure 8-1 Design flowchart 193 Figure 8-2 Proposed reduction factor graph for different fire sizes in symmetric opening arrangement. 197 Figure 8-3 Proposed reduction factor graph for different fire sizes in asymmetric opening arrangement. 198 
Figure 8-4 Proposed reduction factor graph for different fire sizes exposed to rotational

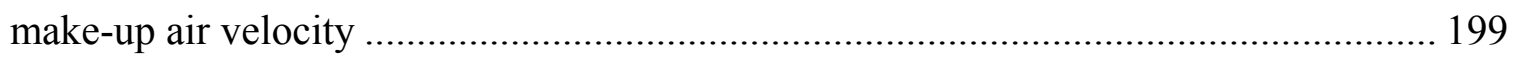




\section{List of Symbols}

\begin{tabular}{|c|c|}
\hline A & Floor area, $\mathrm{m}^{2}$ \\
\hline$A_{v}$ & Area of vent, $\mathrm{m}^{2}$ \\
\hline $\mathrm{A}_{\mathrm{w}}$ & Area of ventilation opening, $\mathrm{m}^{2}$ \\
\hline $\mathrm{C}$ & Vent coefficient \\
\hline $\mathrm{c}_{\mathrm{p}}$ & Specific heat of smoke, $\mathrm{kJ} / \mathrm{kg}^{\circ} \mathrm{C}$ \\
\hline$D$ & Material diffusivity, $\mathrm{m}^{2} / \mathrm{s}$ \\
\hline$D_{i}$ & Diffusion of $i$ th species, $\mathrm{m}^{2} / \mathrm{s}$ \\
\hline $\mathrm{d}$ & Diameter of fuel, $\mathrm{m}$ \\
\hline$f_{a}$ & Opening arrangement factor \\
\hline$f_{b}$ & External force vector (excluding gravity), $\mathrm{N}$ \\
\hline$f_{r}$ & Rotational make-up air factor \\
\hline$g$ & Gravity, $\mathrm{m} / \mathrm{s}^{2}$ \\
\hline $\mathrm{H}$ & Ceiling height above the fuel, $\mathrm{m}$ \\
\hline $\mathrm{H}_{\mathrm{b}}$ & Height of balcony above top of fuel, $\mathrm{m}$ \\
\hline $\mathrm{H}_{\mathrm{exp}}$ & Smoke layer height from the experiment, $\mathrm{m}$ \\
\hline $\mathrm{H}_{\text {pro }}$ & Smoke layer height from the proposed correlation, $\mathrm{m}$ \\
\hline $\mathrm{H}_{\mathrm{v}}$ & Height of flame, $m$ \\
\hline $\mathrm{H}_{\mathrm{w}}$ & Height of the ventilation opening, $\mathrm{m}$ \\
\hline$h$ & Enthalpy, J \\
\hline$M_{F}$ & Fuel molecular weight, g/mol \\
\hline$M_{O}$ & Oxygen molecular weight, g/mol \\
\hline
\end{tabular}




\begin{tabular}{|c|c|}
\hline$\dot{m} "$ & Mass loss rate per area, $\mathrm{g} /\left(\mathrm{sec} \cdot \mathrm{m}^{2}\right)$ \\
\hline$\dot{m}_{e}$ & Mass flow rate of exhaust smoke, $\mathrm{kg} / \mathrm{s}$ \\
\hline$\dot{m}_{i}^{\prime \prime \prime}$ & Production rate of $i$ th species per unit volume, $\mathrm{kg} / \mathrm{m}^{3} . \mathrm{s}$ \\
\hline$\dot{m}_{p}$ & Upward mass flow rate of plume, $\mathrm{kg} / \mathrm{s}$ \\
\hline$\dot{m}_{p, \text { balcony }}$ & Mass flow rate of balcony plume, $\mathrm{kg} / \mathrm{s}$ \\
\hline$\dot{m}_{p, \text { corner(in) }}$ & Mass flow rate of an inside corner plume, $\mathrm{kg} / \mathrm{s}$ \\
\hline$\dot{m}_{p, \text { corner }(\text { out })}$ & Mass flow rate of an exterior corner plume, $\mathrm{kg} / \mathrm{s}$ \\
\hline$\dot{m}_{p, \text { wall }}$ & Mass flow rate of a wall plume, $\mathrm{kg} / \mathrm{s}$ \\
\hline$\dot{m}_{p, \text { window }}$ & Mass flow rate of the window plume, $\mathrm{kg} / \mathrm{s}$ \\
\hline$\dot{m}_{v}$ & Mass flow rate through vent, $\mathrm{kg} / \mathrm{s}$ \\
\hline $\mathrm{N}$ & Interpolation constant \\
\hline $\mathrm{n}$ & Number of data in each series of test \\
\hline$p$ & Pressure, $\mathrm{Pa}$ \\
\hline $\mathrm{P}_{\mathrm{o}}$ & Outside pressure, $\mathrm{kPa}$ \\
\hline $\mathrm{P}_{\mathrm{s}}$ & Pressure of smoke layer at the ceiling, $\mathrm{kPa}$ \\
\hline $\mathrm{P}_{1}$ & Air pressure before probe, $\mathrm{Pa}$ \\
\hline $\mathrm{P}_{2}$ & Air pressure after probe, $\mathrm{Pa}$ \\
\hline$\dot{Q}$ & Heat release rate, $\mathrm{kW}$ \\
\hline$\dot{Q}_{c}$ & Convective heat release rate, $\mathrm{kW}$ \\
\hline$\dot{q}^{\prime \prime}$ & Heat flux vector \\
\hline$\dot{q}^{\prime \prime \prime}$ & Heat release rate per unit volume, $\mathrm{kW} / \mathrm{m}^{3}$ \\
\hline RF & Reduction Factor \\
\hline
\end{tabular}




\begin{tabular}{|c|c|}
\hline $\mathrm{T}_{\mathrm{a}}$ & Ambient temperature, $\mathrm{K}$ \\
\hline $\mathrm{T}_{\mathrm{b}}$ & The temperature near the bottom of the compartment, $\mathrm{K}$ \\
\hline$T_{l}$ & Lower layer temperature, ${ }^{\circ} \mathrm{C}$ \\
\hline $\mathrm{T}_{\max }$ & The maximum temperature in the compartment, $\mathrm{K}$ \\
\hline $\mathrm{T}_{\mathrm{o}}$ & Centerline temperature, $\mathrm{K}$ \\
\hline $\mathrm{T}_{\mathrm{s}}$ & Temperature of the smoke layer, ${ }^{\circ} \mathrm{C}$ \\
\hline $\mathrm{T}_{\mathrm{u}}$ & Upper layer temperature, ${ }^{\circ} \mathrm{C}$ \\
\hline $\mathrm{t}$ & Time from ignition, sec \\
\hline $\mathrm{u}$ & Wind velocity, $\mathrm{m} / \mathrm{s}$ \\
\hline$u=(u, v, w)$ & Velocity Vector \\
\hline $\mathrm{V}$ & Air velocity, $\mathrm{m} / \mathrm{s}$ \\
\hline $\mathrm{V}_{1}$ & Air velocity before the probe, $\mathrm{m} / \mathrm{s}$ \\
\hline $\mathrm{V}_{2}$ & Air velocity after the probe, $\mathrm{m} / \mathrm{s}$ \\
\hline$\dot{V}_{\text {exh }}$ & Volumetric flow rate of the exhaust gases, $\mathrm{m}^{3} / \mathrm{s}$ \\
\hline$v_{F}$ & Fuel stoichiometric coefficient \\
\hline$v_{o}$ & Oxygen stoichiometric coefficient \\
\hline $\mathrm{W}$ & Plume width as it spills under balcony, $\mathrm{m}$ \\
\hline$Y_{f}$ & Mass fraction of fuel, $\mathrm{g} / \mathrm{g}$ \\
\hline$Y_{i}$ & Mass fraction of $i$ th species, $\mathrm{g} / \mathrm{g}$ \\
\hline$Y_{o}$ & Mass fraction of oxygen, $\mathrm{g} / \mathrm{g}$ \\
\hline$Y_{F}^{I}$ & Mass fraction of fuel in the fuel stream, $\mathrm{g} / \mathrm{g}$ \\
\hline$Y_{O}^{\infty}$ & Mass fraction of ambient oxygen, $\mathrm{g} / \mathrm{g}$ \\
\hline Z & Interface height above the fuel, $\mathrm{m}$ \\
\hline
\end{tabular}




$\begin{array}{ll}\mathrm{Z}_{1} & \text { Mean flame height, } \mathrm{m} \\ z & \text { Height, } \mathrm{m} \\ z_{b} & \text { Height above balcony, } \mathrm{m} \\ z_{\text {int }} & \text { Interface height, } \mathrm{m} \\ z_{w} & \text { Height above the top of the compartment window, } \mathrm{m} \\ a & \text { Height adjusted factor, } \mathrm{m} \\ \beta & \text { Tilt angle, rad } \\ \varepsilon & \text { Dissipation rate, } \mathrm{J} / \mathrm{kg} \cdot \mathrm{s} \\ \rho & \text { Gas density, kg/m } \mathrm{m}^{3} \\ \rho_{a} & \text { Density of ambient air, } \mathrm{g} / \mathrm{m}^{3} \\ \rho_{g} & \text { Density of hot gases, } \mathrm{kg} / \mathrm{m}^{3} \\ \rho_{s} & \text { Density of the smoke layer, } \mathrm{kg} / \mathrm{m}^{3} \\ \sigma_{e s t} & \text { Standard error of the estimate } \\ \tau_{i j} & \text { Viscous stress tensor }\end{array}$




\section{Chapter 1: Introduction}

\subsection{Background}

An atrium provides an attractive environment in buildings such as luxurious hotels, shopping centers and prestigious commercial buildings. An atrium has a large undivided space which provides a visual luxury and special appeal. Fire safety is one of the main concerns for designing the atrium. In the event of fire in an atrium, smoke rises and fills the atrium and the inter connected floors quickly, which may endanger occupants on these floors.

An atrium connects two or more floors along the height of a building. Depending on design requirements, the sides of an atrium can be open or closed to some of the floors in the building. In some cases, a single building can contain two or more atria which can be interconnected through some of the floors or at the ground floor.

The concept of floor compartmentation in a building restricts the spread of fire and smoke along the height of the building. The atrium violates the concept of floor compartmentation by providing an open space along the height of the building. Therefore, in the event of fire, the smoke and fire products will not be limited to the floor of fire origin but they are allowed to move to the interconnected floors to the atrium. 
One of the essential objectives of many building codes and regulations is to protect people and property from exposure to smoke and other fire products. Most building codes emphasize some special requirements for atrium design including:

- Designing an automatic sprinkler system for the entire building including the atrium.

- Controlling flammable and combustible materials on the ground floor and the interconnected floors to the atrium.

- Designing appropriate smoke management systems to provide a safe and nonsmoke contaminated height on egress routes.

The National Fire Protection Association (NFPA) publication, Guide for Smoke Management Systems in Malls, Atria, and Other Large Spaces, NFPA 92B (2009) and ASHRAE/SFPE publication, Handbook of Smoke Control Engineering (Klote et al., 2012) provide design requirements for mechanical smoke management systems. The appropriate performance of the mechanical exhaust system is shown in Figure 1-1. The behavior of the plume above the fire depends on the plume boundaries. In order to prevent turbulence in smoke movement, building codes, such as NFPA 92B (2009), restrict the make-up air velocity to less than $1 \mathrm{~m} / \mathrm{s}$. The effect of turbulence on atrium smoke conditions due to the impact of higher make-up air velocities is illustrated in Figure 1-2. 


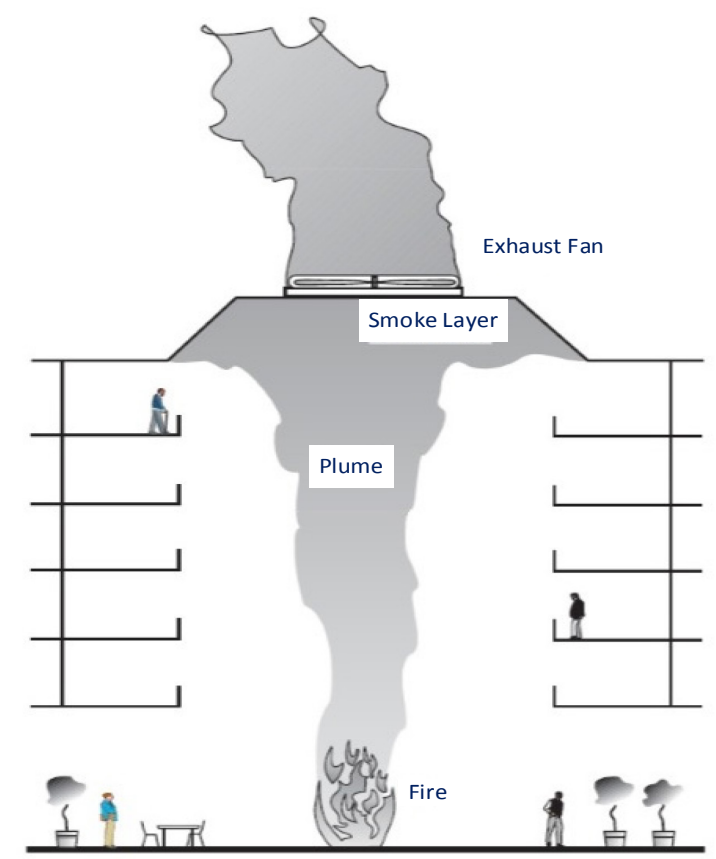

Figure 1-1 Intended operation of smoke management system [modified from Lougheed, G. D. (2000)]

The $1 \mathrm{~m} / \mathrm{s}$ air velocity limitation is based on limited research on the impact of higher air velocity which could cause disruption of the plume dynamic. Providing sufficient opening area to limit the air velocity to $1 \mathrm{~m} / \mathrm{s}$ air velocity is a challenge for architects. Many architects complain that the atrium geometry does not always allow the provision of an appropriate opening arrangement with sufficient opening area (Mudan and Croce 1998, 2002). For instance, for a $25 \mathrm{~m}$ tall atrium with a $2 \mathrm{MW}$ design fire the volumetric flow rate of the smoke exhaust should be $113.52 \mathrm{~m}^{3} / \mathrm{s}$ in order to keep the smoke depth at $2 \mathrm{~m}$ below the ceiling. To ensure the make-up air velocity does not exceed $1 \mathrm{~m} / \mathrm{s}$, the area of the opening should be $114 \mathrm{~m}^{2}$ or more. If this opening is 
located at the ground level and assuming openings are $3 \mathrm{~m}$ high, the length of opening would be $38 \mathrm{~m}$. Having such an opening for many buildings may not be possible.

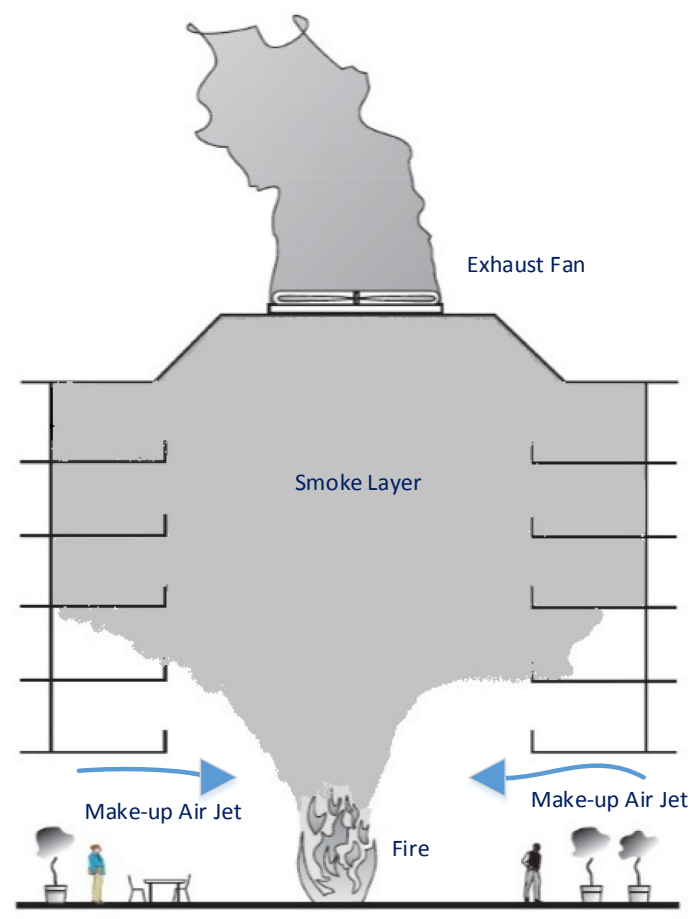

Figure 1-2 Air stream impact destroys plume and exposes occupants to smoke [modified from Lougheed, G. D. (2000)]

Due to the potentially large size of atria, studying the effectiveness of smoke management systems through full-scale experiment is very difficult and expensive. A lot of research has been devoted to the study of these systems using analytical and numerical models (Kerber and Milke, 2007) as well as small-scale experiments. The impact of the velocity of make-up air on a plume is also illustrated in Figures 1-3 and 14, which show the results of CFD simulations.

Figure 1-3 shows that with a 1-m/s make-up air velocity, the smoke management system works appropriately in keeping the smoke moving upward and Figure 1-4 
illustrates how the 3-m/s make-up air velocity causes plume disruption and a decrease of the smoke layer height.

In spite of different studies that have been carried out on smoke management in atria, more research is still needed to investigate the existing correlations and validate the computer models used for the design of smoke management systems.

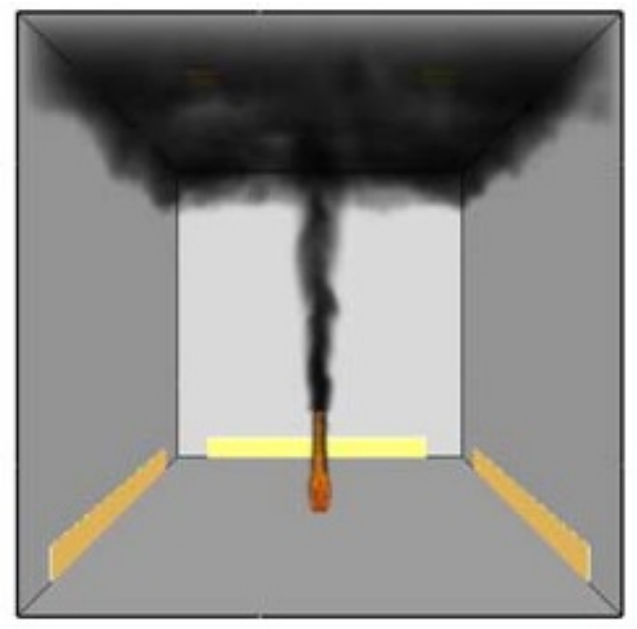

Figure 1-3 Inlet air does not affect plume in the case of low make-up air velocity [Kerber, S. and Milke, J. A. (2007)]

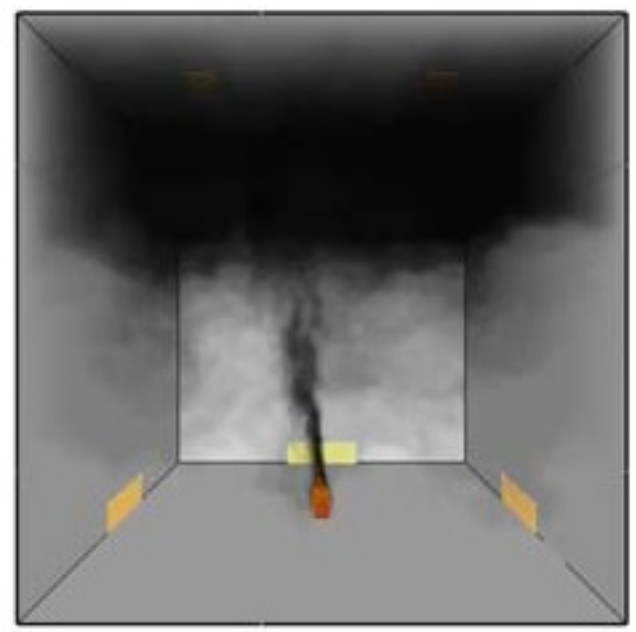

Figure 1-4 Inlet air spreads products of combustion throughout atrium space in the case of high make-air velocity [Kerber, S. and Milke, J. A. (2007)] 


\subsection{Objectives and Scope}

The building code approach to atrium smoke management is based on maintaining the smoke layer interface at a specific level above the highest occupied floor in an atrium. Selecting an appropriate exhaust rate for the smoke management system is pivotal. Providing sufficient make-up air to the atrium and maintain the air velocity below the 1 $\mathrm{m} / \mathrm{s}$ simultaneously is a design challenge for smoke management systems.

Increasing the air entrainment into the plume increases plume dilution and decreases the smoke hazard. Although the diluted smoke causes relatively little threat to the occupants in the atrium, a more powerful exhaust system will be required to remove the diluted smoke from the atrium.

Existing obstructions in the path of a smoke plume can deflect the smoke and plume movement in the atrium (Hansell and Morgan, 1994), and the presence of a pre-existing stratification layer in the atrium may affect the effectiveness of an atrium smoke management system (Hinckley, 1995). Also smoke can mix with the air and move through the interconnected floors and adjacent spaces and endanger occupants on egress routes. Moreover, the smoke management system may not remove the smoke from the atrium if the smoke cannot reach the ceiling. In this case, smoke may accumulate in other zones where it can move into the interconnected spaces. 
Plugholing is another phenomenon that may occur when the exhaust system removes the air from the cold lower layer simultaneously with the smoke from the upper layer. Plugholing impacts the performance of the mechanical exhaust system, decrease the clear height in the atrium and causes people and property to be exposed to the smoke and fire gases (Lougheed, 2000).

\subsubsection{Objectives}

In this research, full-scale tests of atrium fires have been conducted together with CFD modelling to investigate the effect of make-up air velocity on the conditions in an atrium including smoke layer height and temperature. Also the effect of opening locations and air flow direction are studied. Comparison of results of different full-scale fire tests and CFD modelling is presented in order to explain the mechanisms of smoke flow in atrium when an air stream impacts the smoke plume.

\subsubsection{Scope}

The project involves several full-scale tests in the Carleton University Fire Lab as well as computer modelling using the Fire Dynamics Simulator (FDS) (McGrattan et al., 2010). Simulations have been conducted using the same conditions as in the full-scale tests in order to compare the predictions with the experimental results (Hadjisophocleous and McCartney, 2005). The following parameters are considered:

- $\quad$ Fire size

- Make-up air velocity

- Opening locations 
- Location of fire

- Air flow direction

\subsubsection{Fire Size}

Fire size is varied from 1-5 MW, which covers most of the expected fires in an atrium. More attention is given to the smaller size fires because these fires generate a plume with less buoyancy forces that is more susceptible to disruption by the flow of make-up air.

\subsubsection{Make-up Air Velocity}

One of the main parameters that may have effects on the smoke layer height is the velocity of the make-up air. Existing building regulations emphasize the make-up air velocity should be less than $1 \mathrm{~m} / \mathrm{s}$. The full-scale experiments consider velocities ranging from 1 to $2 \mathrm{~m} / \mathrm{s}$ and CFD simulations consider air velocity ranging from 1 to 3 $\mathrm{m} / \mathrm{s}$ in order to achieve a solid conclusion. In the experiments the selected velocity values are controlled using a wind tunnel.

\subsubsection{Location of Entry Air Openings}

The make-up air entry can be located at any side of the atrium depending on the architectural design restrictions. The most severe case of opening arrangement is when a one side opening arrangement is used (Souza and Milke, 2004). In this opening arrangement the make-up air enters the atrium from one side of the opening and may deflect the fire plume and smoke movement. 


\subsubsection{Fire Location Relative to Wall Opening}

If the fire occurs close to the opening, the probability of plume and smoke deflection increases. However, the location of the fire is one of the parameters that it is mostly unpredictable.

\subsubsection{Air Flow Direction to Fire}

The direction of the air flow can create turbulence in the smoke plume depending on whether air is blown directly or indirectly towards the plume. Also locating the opening in the corners of the atrium may result in rotating make-up air that may cause more disruption of smoke movement (Kerber and Milke, 2007).

\subsection{Thesis Organization}

The organization of the remaining chapters is outlined as follows:

- Chapter 2

Includes a comprehensive review of fire plumes, smoke management and previous research related to make-up air effect on atrium smoke conditions.

- Chapter 3

Provides a description of Carleton University's atrium, instrumentation, smoke layer height estimation method and experimental plan.

- $\quad$ Chapter 4

Contains a description of the computational model used in this study, including the numerical method for determining interface height, boundary conditions, computational grid, air flow and simulation plan. 
- Chapter 5

Presents the experimental results of different make-up air velocities on the smoke layer height considering atrium fires ranging from $1 \mathrm{MW}$ to $5 \mathrm{MW}$. Moreover, this chapter includes the comparison of CFD modelling and experimental data.

- $\quad$ Chapter 6

Presents the experimental results of different opening configurations on smoke layer height with atrium fires ranging from $1 \mathrm{MW}$ to $5 \mathrm{MW}$ and make-up air velocities ranging from $1 \mathrm{~m} / \mathrm{s}$ to $2 \mathrm{~m} / \mathrm{s}$. A comparison of CFD modeling predictions and experimental data is also presented in this chapter.

- $\quad$ Chapter 7

Presents the experimental results of different air flow directions, including direct air flow and rotational make-up air, on the smoke layer height with considering atrium fire ranging from $1 \mathrm{MW}$ to $5 \mathrm{MW}$ and make-up air velocities ranging from $1 \mathrm{~m} / \mathrm{s}$ to $2 \mathrm{~m} / \mathrm{s}$. In addition, this chapter provides a comparison of CFD modeling predictions and experimental data.

- $\quad$ Chapter 8

Provides design guidelines for the atrium smoke management system, presents examples of using the proposed guidelines and compares the proposed guidelines for different fire sizes.

- $\quad$ Chapter 9

Provides a brief summary of this dissertation and presents the main conclusions and recommendations for future work. 


\section{Chapter 2: Literature Review}

\subsection{Introduction}

Smoke management problems in atria have been studied by several researchers. Smoke management issues include the problems in natural ventilation, smoke filling and mechanical smoke exhaust system. This chapter contains a brief review of the basis of smoke management in atria, existing design methods and previous research on atrium smoke movement.

According to NFPA 92B (2009), "smoke consists of the airborne solid and liquid particulates and gases evolved when a material undergoes pyrolysis or combustion, together with the quantity of air that is entrained or mixed into the mass". The smoke is allowed to move through the atrium and mixes with the air in the open space in the atrium. The smoke temperature and the concentration of the toxic gases decrease when air mixes with the smoke.

Smoke is one of the main threats in the event of a fire, as it can move quickly through a building, reduce visibility, spread toxic gases and expose occupants to convective heat (Klote et al., 2012). The reduction in visibility will affect people in the atrium and in the other interconnected zones to the atrium. Therefore it will affect the evacuation time. 


\subsection{Fire Plumes}

The fire plume is a mixture of buoyant gases which rise towards the ceiling from the combustion process in the area of fire. The fire plume begins from the ignition stage and continues during the smoldering and flaming stages and usually ends with the occurrence of flashover. The fire plume is defined as the buoyant flow which includes the fire flames.

Diffusion flames are formed from a mixture of volatiles which are produced during the combustion process and the surrounding air (Heskestad 1984). The buoyant flow of the combustion products and the surrounding air can be confined by limiting the side's boundaries of surrounding air in a compartment. The difference in the density of the hot gasses and the cold air causes the air with lower density rise and pushes the hot gases

upward. Since the hot gases move upward, the cold air with less density entrains into the fire plume due to the buoyant air circulation. Klote et al. (2012) listed five different types of plumes described in the following sections.

\subsubsection{Axisymmetric Plume}

One of the most common types of fire plume is the buoyant axisymmetric plume. Since the fresh air entrains from all directions to the fire plume, there is an axis of symmetry along the vertical centerline of the plume. The mass flow rate of the axisymmetric plume is described in Eq. 2-1. The axisymmetric plume is assumed to be the most intense fire plume, as the fresh air is allowed to mix with the fire plume from all directions. 


$$
\dot{m}_{p}=0.071 \dot{Q}_{c}{ }^{1 / 3} Z^{5 / 3}+0.0018 \dot{Q}_{c} \text { for } \mathrm{Z}_{1} \leq \mathrm{Z}
$$

Eq. 2-1

Where:

$\dot{m}_{p}=$ Upward mass flow rate of plume, $\mathrm{kg} / \mathrm{s}$

$\dot{Q}_{c}=$ Convective heat release rate, $\mathrm{kW}(0.65 \sim 0.7 \dot{Q})$

$\dot{Q}=$ Heat release rate, $\mathrm{kW}$

$\mathrm{Z}=$ Interface height above the fuel, $\mathrm{m}$

$\mathrm{Z}_{1}=$ Mean flame height, $\mathrm{m}$

Flame Height: The mean flame height, $Z_{1}$, depends on the fire conditions such as heat release rate of fire, ambient conditions and fire geometry. The mean flame height is commonly calculated from:

$$
Z_{1}=0.166 \dot{Q}_{c}^{2 / 5}
$$

For $\mathrm{Z}$ values lower than the mean flame height, the plume mass flow rate is described by:

$$
\dot{m}_{p}=0.032 \dot{Q}_{c}^{3 / 5} Z \text { for } \mathrm{Z}<\mathrm{Z}_{1}
$$




\subsubsection{Wall Plume}

The fire location closed to the wall reduces air entrainment to the fire plume. As the air is allowed to entrain into the fire plume from one side of the plume, the mass flow rate from the axisymmetric plume can be cut in half with twice the heat release rate (Zukoski, 1995). The wall plume flow rate proposed by Zukoski is:

$$
\dot{m}_{p}=\frac{1}{2} 0.07\left(2 \dot{Q}_{c}\right)^{1 / 3} Z^{5 / 3}
$$

Where:

$\dot{m}_{p, \text { wall }}=$ Mass flow rate of a wall plume, $\mathrm{kg} / \mathrm{s}$

\subsubsection{Corner Plume}

The fire location near to the inside corner of the walls allows the air to be entrained into the plume from one quarter side of the axisymmetric plume. In order to calculate the mass flow rate of the corner plume, Zukoski (1995) proposed to decrease the axisymmetric plume by a quarter with respect to four times the heat release rate.

$$
\dot{m}_{p, \text { corner }(i n)}=\frac{1}{4} 0.07\left(4 \dot{Q}_{c}\right)^{1 / 3} Z^{5 / 3}
$$

Where:

$\dot{m}_{p, \text { corner(in) }}=$ Mass flow rate of an inside corner plume, $\mathrm{kg} / \mathrm{s}$

The fire location closed to the outside corner also causes the plume flow rate of the axisymmetric plume to decrease to three quarters of the plume flow with four-thirds 
times the heat release rate. Eq. 2-6 shows the plume flow rate of a fire located in the outside corner of walls.

$$
\dot{m}_{p, \text { corner }(\text { out })}=\frac{3}{4} 0.07\left(\frac{4}{3} \dot{Q}_{c}\right)^{1 / 3} Z^{5 / 3}
$$

Where:

$\dot{m}_{p, \text { corner }(\text { out })}=$ Mass flow rate of an exterior corner plume, $\mathrm{kg} / \mathrm{s}$

\subsubsection{Balcony Spill Plume}

A balcony spill plume occurs when the fire origin is located under a balcony. In the case of balcony spill plume, the fire plume moves horizontally under the balcony and vertically spills into the atrium when it reaches the end of balcony (Klote et al., 2012). The mass flow rate in balcony spill plume is approximated as (Law, 1986; CIBSE, 1995):

$$
\dot{m}_{p, \text { balcony }}=0.36\left(\dot{Q} W^{2}\right)^{1 / 3}\left(z_{b}+0.25 H_{b}\right)
$$

Where:

$\dot{m}_{p, \text { balcony }}=$ Mass flow rate of balcony plume at height $z_{b}, \mathrm{~kg} / \mathrm{s}$

$\mathrm{W}=$ Plume width as it spills under balcony, $\mathrm{m}$

$z_{b}=$ Height above balcony, $\mathrm{m}$

$\mathrm{H}_{\mathrm{b}}=$ Height of balcony above top of fuel, $\mathrm{m}$ 


\subsubsection{Window Plume}

A window plume occurs when the fire origin is located inside a compartment in an atrium, and the fire plume is allowed to escape through an opening. Since the window plume is caused by a fire inside a compartment, NFPA 92B (2009) states that the window plume occurs after the flashover in a ventilation controlled conditions. Therefore the heat release rate based on a ventilation controlled fire is (Klote et al., 2012):

$$
\dot{Q}=1260 A_{w} H_{w}^{1 / 2}
$$

Where:

$$
\begin{aligned}
& A_{w}=\text { Area of ventilation opening, } m^{2} \\
& H_{w}=\text { Height of the ventilation opening, } m
\end{aligned}
$$

The mass flow for window plume is calculated from:

$$
\dot{m}_{p, \text { window }}=0.071 \dot{Q}_{c}^{1 / 3}\left(z_{w}+a\right)^{5 / 3}+0.0018 \dot{Q}_{c}
$$

Where:

$\dot{m}_{p, \text { window }}=$ Mass flow rate of the window plume, $\mathrm{kg} / \mathrm{s}$

$z_{w}=$ Height above the top of the compartment window, $\mathrm{m}$

$a=$ Height adjusted factor, $\mathrm{m}$

Which is:

$$
a=2.40 A_{w}{ }^{2 / 5} H_{w}{ }^{1 / 5}-2.1 H_{w}
$$


Substituting $\dot{Q}_{c}$ in Eq. $2-9$ results in:

$$
\dot{m}_{p, \text { window }}=0.68\left(A_{w} H_{w}{ }^{1 / 2}\right)^{1 / 3}\left(z_{w}+a\right)^{5 / 3}+1.59 A_{w} H_{w}{ }^{1 / 2}
$$

Although several correlations have been proposed to calculate the mass flow rate, flame height and maximum temperature of fire plumes, Heskestad's (1986) research on fire plumes is commonly used as a basis for building codes. In this study, the Heskestad's equations has been used to characterize the fire plume. Since the interface height is considerably greater than the virtual origin height, the virtual origin effect on the fire plume is neglected for the atrium correlations. Figure 2-1 illustrates the virtual origin of fire as Zo.

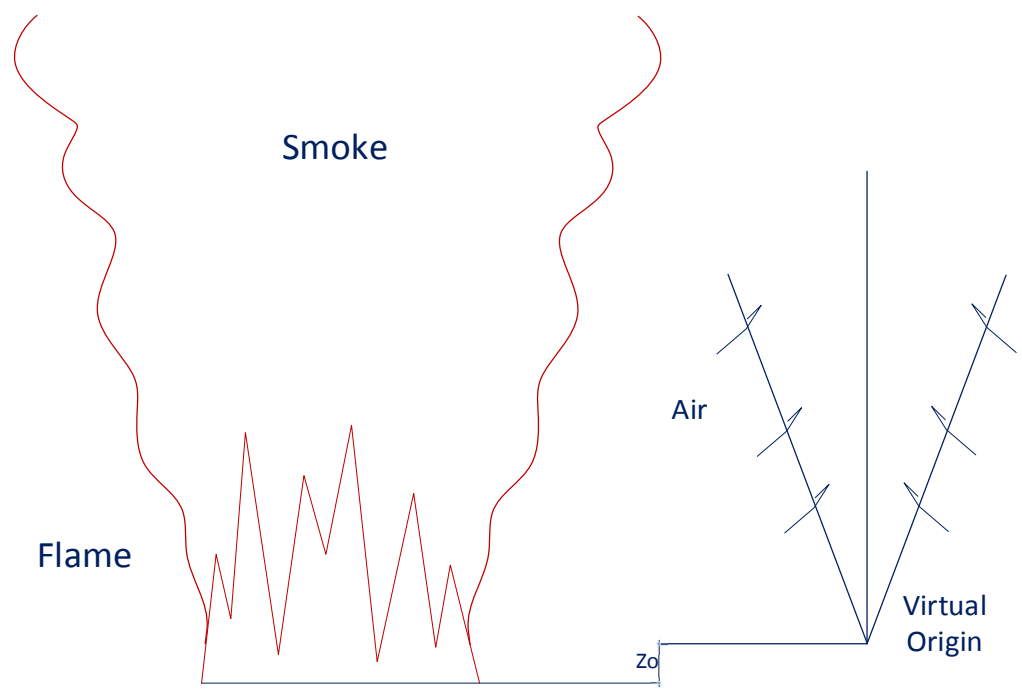

Figure 2-1 Schematic diagram of an axisymmetric plume 


\subsection{Maximum Temperature}

Heskestad (1986) states that the centerline temperature is the largest plume temperature at any height. The plume temperature changes along the height of plume. The maximum centerline temperature of a plume at any height is calculated from:

$$
T_{o}=25 \frac{\dot{Q}_{c}^{2 / 3}}{Z^{5 / 3}}+T_{a}
$$

Where:

$\mathrm{T}_{\mathrm{o}}=$ Centerline temperature, $\mathrm{K}$

$\mathrm{T}_{\mathrm{a}}=$ Ambient temperature, $\mathrm{K}$

\subsection{Impact of Wind on Flames}

Figure 2-2 shows the effect of wind on flames. Several researchers investigated the effect of wind on flames. Thomas (1962) conducted several experiments on wood cribs and proposed a correlation to determine the flame tilt angle:

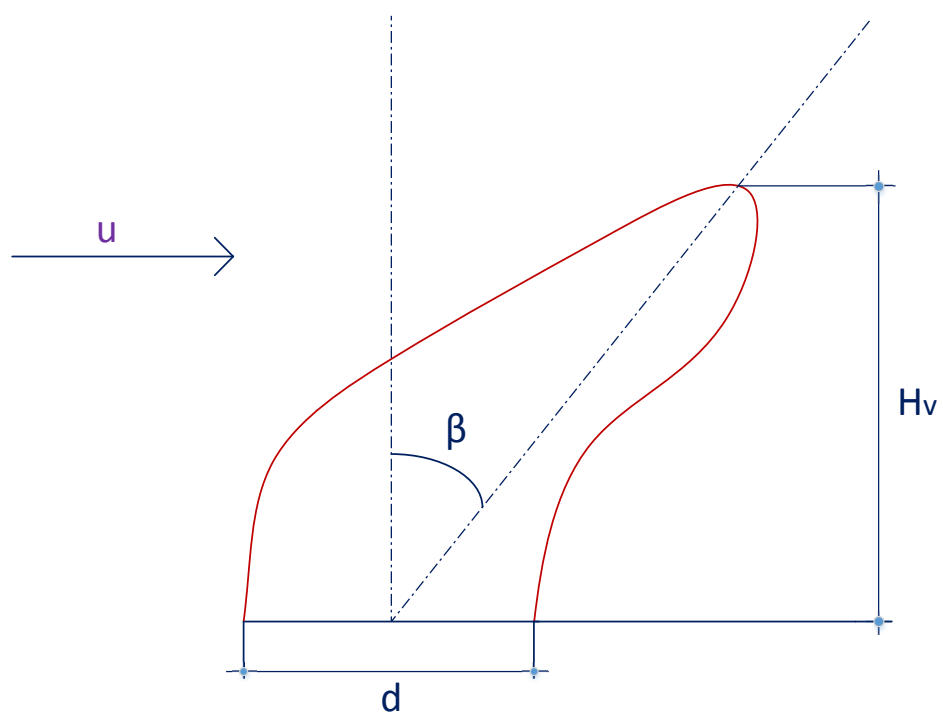

Figure 2-2 Flame inclination due to wind 


$$
\cos \beta=0.7\left[\frac{u}{\left(g \dot{m}^{\prime \prime} d / \rho_{a}\right)^{1 / 3}}\right]^{-0.49}
$$

Where:

$\beta=$ Tilt angle, rad

$\mathrm{u}=$ Wind velocity, $\mathrm{m} / \mathrm{s}$

$\dot{m}^{\prime \prime}=$ Mass loss rate per area, $\mathrm{g} /\left(\mathrm{sec} . \mathrm{m}^{2}\right)$

$\mathrm{d}=$ Diameter of fuel, $\mathrm{m}$

$\rho_{\mathrm{a}}=$ Density of ambient air, $\mathrm{g} / \mathrm{m}^{3}$

$\mathrm{g}=$ Acceleration due to gravity $\left(9.8 \mathrm{~m} / \mathrm{s}^{2}\right)$

$\mathrm{H}_{\mathrm{v}}=$ Height of flame, $\mathrm{m}$

Also, the American Gas Association (AGA, 1974) proposed a correlation to calculate the tilt angle of flames from experimental data:

$$
\cos \beta= \begin{cases}=1 & \text { for } U^{*} \leq 1 \\ & \\ =\left(\frac{1}{U^{*}}\right)^{1 / 2} & \text { for } U^{*} \geq 1\end{cases}
$$

Where:

$$
U^{*}=\frac{u}{\left(g \dot{m}^{\prime \prime} d / \rho_{a}\right)^{1 / 3}}
$$

Zhou (2006) studied the effect of the air flow on the fire plume by conducting CFD modelling. She considered a $30 \mathrm{~m} \times 10 \mathrm{~m}$ x $6 \mathrm{~m}$ compartment when the two ends of compartment were open, one end was assigned to a flow with constant velocity and the 
other end was passive opening. The effects of $0.5 \mathrm{~m} / \mathrm{s}, 1 \mathrm{~m} / \mathrm{s}, 1.5 \mathrm{~m} / \mathrm{s}$ and $2 \mathrm{~m} / \mathrm{s}$ air velocities were investigated on $0.5 \mathrm{MW}, 1 \mathrm{MW}$ and $5 \mathrm{MW}$ fire. The FDS results were compared with calculations using Thomas (1962) and American Gas Association method (AGA, 1974).

For the $0.5 \mathrm{MW}$ fire, the results of CFD modelling, AGA and Thomas were very close. For the $1 \mathrm{MW}$ fire, the simulation results were different from the AGA results but were close to the results of Thomas. For the $5 \mathrm{MW}$ fire, she found a good agreement between the simulation results and the results of Thomas.

Based on the simulation results, she concluded that FDS is capable to model the effect of airflow on the flames. In addition, the modelling results showed that the effect of air velocity on the flames of small fires is more pronounced than the effect of air velocity on the flames of large fires. Moreover, the results indicated that even $1 \mathrm{~m} / \mathrm{s}$ air velocity causes the flames to tilt. Higher air velocities increase the flame tilts considerably with tilt angle larger than $45^{\circ}$.

\subsection{Smoke Layer Height}

The smoke management system is designed to maintain a specific clear height. The intended operation of a smoke management system is shown in Figure 2-3. This figure shows how an appropriate smoke management system maintains the smoke above the clear height level and prevents occupants from being exposed to the smoke. 


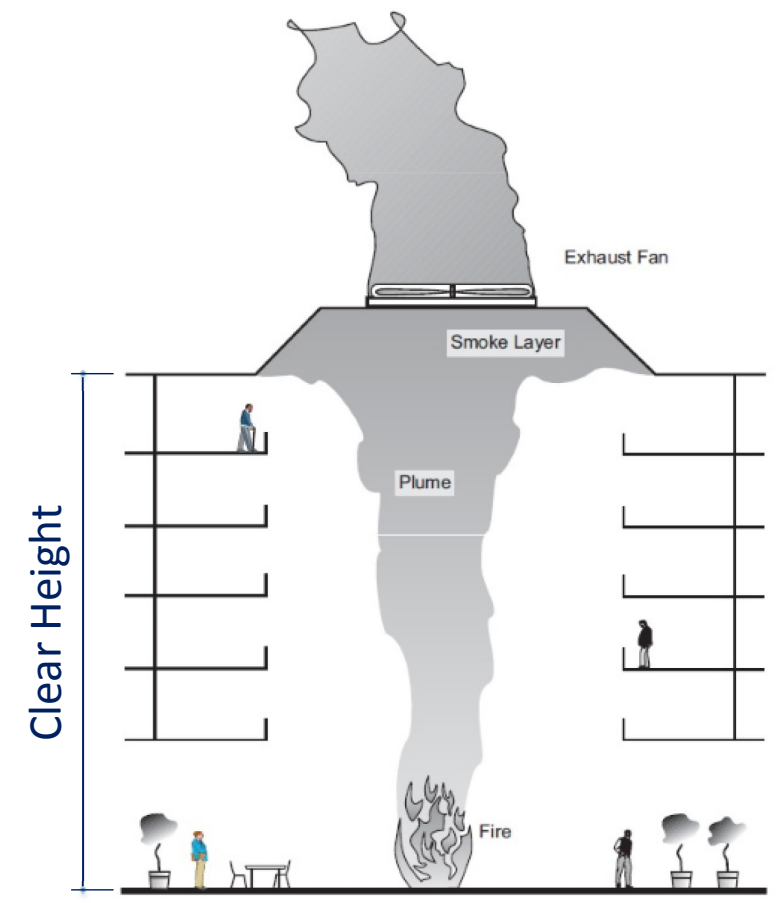

Figure 2-3 Clear height with steady fire [modified from Lougheed, G. D. (2000)]

Natural filling in an atrium occurs when the atrium is not equipped with a smoke exhaust system. W. K. Chow (1993) proposed an equation for calculating the mass flow rate of natural filling.

$$
\frac{d}{d t}\left[\rho_{a} A(H-Z)\right]=\dot{m}_{p}
$$

Where:

$\mathrm{A}=$ Floor area, $\mathrm{m}^{2}$

$\mathrm{H}=$ Ceiling height above the fuel, $\mathrm{m}$

$\mathrm{t}=$ Time from ignition, $\mathrm{sec}$ 
The axisymmetric plume mass flow rate at the smoke layer height is given by Eq. 2-1. This equation considers the fire as a point fire which is located at the floor of the atrium and far from the walls. The smoke layer interface height is the distance between the top of the fuel and the first indication of smoke in the atrium. In all of the plume correlations heat transfer between the atrium walls and the ceiling to the outside of the atrium is assumed to be negligible.

Wong (2001) also proposed an equation to determine the smoke layer height in atrium:

$$
\frac{Z}{H}=\left(0.0018 \dot{Q}^{1 / 3} t+1\right)^{-(3 / 2)}
$$

Heskestad also proposed a correlation to calculate the height of the smoke layer as a function of time. This correlation is based on the experimental results and has been used by NFPA 92B (2009). The Heskestad correlation provides a conservative estimate of the smoke interface height:

$$
\frac{Z}{H}=1.11-0.28 \ln \left[\frac{t \dot{Q}^{1 / 3} H^{-(4 / 3)}}{\left(\frac{A}{H^{2}}\right)}\right]
$$

Cooper et al. (1982) proposed the N-Percentage method in order to determine the interface height between the hot upper layer and the cold lower layer based on a limited 
measured temperature along the height of an atrium. They suggested that the interface is at the elevation where the temperature, $T_{n}$ is equal to:

$$
T_{n}=N\left(T_{\max }-T_{b}\right)+T_{b}
$$

Where:

$\mathrm{T}_{\max }=$ The maximum temperature in the compartment, $\mathrm{K}$

$T_{b}=$ The temperature near the bottom of the compartment, $\mathrm{K}$

$\mathrm{N}=$ Interpolation constant typically in the range of 0.1 to 0.2

A similar equation can also be used to determine the interface height based on $\mathrm{CO}_{2}$ concentrations. Zhou (2006) observed that both temperature and $\mathrm{CO}_{2}$ concentration yield the same height for the smoke layer by simulating a large number of atrium fires and measuring the temperature and $\mathrm{CO}_{2}$ concentration along the atrium height.

Lougheed et al. (1999) stated that a value of $\mathrm{N}$ between 0.1-0.2 gives a smoke interface height near the bottom of the transition zone. In this study, a clear height is defined using Eq. 2-19 with $\mathrm{N}$ set to 0.2 to determine the smoke layer height from the experimental data. 


\subsection{Atrium Smoke Management}

The objective of a smoke management is to maintain the smoke layer above the highest floor, in order to limit smoke movement to the interconnected floors to the atrium. The smoke management system is designed in an atrium to limit the exposure of occupants during the evacuation. Designing the smoke management system in atria is essential, as the sprinkler system is not always effective in fire suppression in large spaces.

Different approaches have been used for fire safety design of atrium (Klote et al., 2012):

1) Natural ventilation

2) Smoke filling

3) Mechanical exhaust

\subsubsection{Natural Ventilation in Atrium}

One of the most popular methods for smoke management in many building codes is natural ventilation. Natural ventilation is shown in Figure 2-5. 


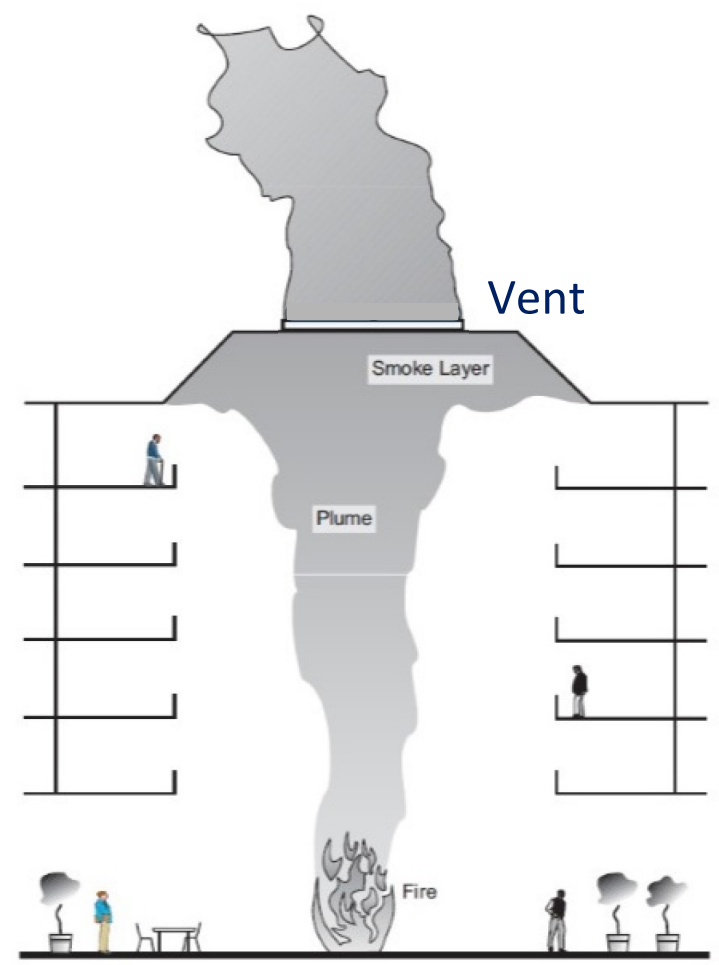

Figure 2-4 Natural venting in an atrium [modified from Lougheed, G. D. (2000)]

In the case of natural ventilation the buoyancy of smoke pushes the smoke to escape from an opening at the top of the atrium Klote et al. (2012). Klote proposed an equation for natural ventilation by equalizing the rate of mass flow of the smoke entering the smoke layer to the rate of smoke escaping from the top of the atrium:

$$
\dot{m}_{v}=C A_{v}\left[2 \rho_{g}\left(P_{s}-P_{o}\right)\right]^{1 / 2}
$$

Where:

$\dot{m}_{v}=$ Mass flow rate through vent, $\mathrm{kg} / \mathrm{s}$

$\mathrm{C}=$ Vent coefficient 0.6

$\rho_{\mathrm{g}}=$ Density of hot gases, $\mathrm{kg} / \mathrm{m}^{3}$ 
$\mathrm{A}_{\mathrm{v}}=$ Area of vent, $\mathrm{m}^{2}$

$\mathrm{P}_{\mathrm{S}}=$ Pressure of smoke layer at the ceiling, $\mathrm{kPa}$

$\mathrm{P}_{\mathrm{o}}=$ Outside pressure, $\mathrm{kPa}$

\subsubsection{Smoke Filling in Atrium}

In very large spaces where the evacuation time may be shorter than the filling time, the smoke filling approach is useful. The evacuation time includes the alarm time and the time required by occupants to become aware of the fire and get ready to evacuate, as well as and the time for moving to the exits. The smoke filling time can be calculated from the correlations or by running a zone model.

Zone models consider two layers with uniform properties: the hot upper layer, and the cold lower layer (Bukowski, 1991; Jones 1983). The bottom of the hot layer is considered as the smoke interface height in the two zone model. Figure 2-4 illustrates the two zone model assumptions.

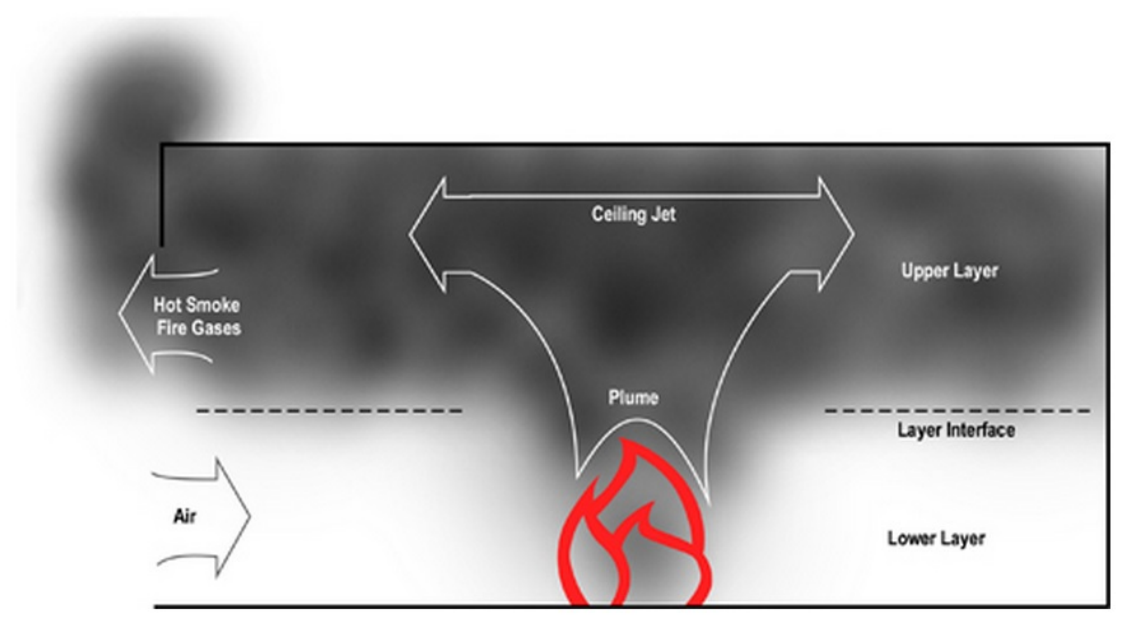

Figure 2-5 Schematic diagram of two zone model 
Several researchers carried out experimental studies on atrium smoke management. These experimental studies including Nowler (1987), Mulholland et al. (1981), Cooper et al. (1982) and Hagglund et al. (1985) are the basis of the atrium correlations. Although the two zone model is a good assumption for smoke management studies, the experimental research shows that there is a transition line between the cold lower layer and hot upper layer in real fires. The bottom of the transition line has been assumed as the first indication of smoke by several researchers.

For instance, Eq. 2-18 for smoke filling is developed from the experimental studies for a specific cross-sectional area with respect to height and fire size. It is also assumed that the fire plume has no contact with the walls. This causes the worst case scenario because wall contact decreases the air entrainment into the plume.

\subsubsection{Mechanical Exhaust System in Atrium}

Mechanical smoke management system is the most effective method to exhaust the smoke out of the atrium. The HVAC system can be used as the mechanical exhaust system for the purpose of smoke management. Figure 2-6 shows the operation of the mechanical smoke exhaust system in an atrium. 


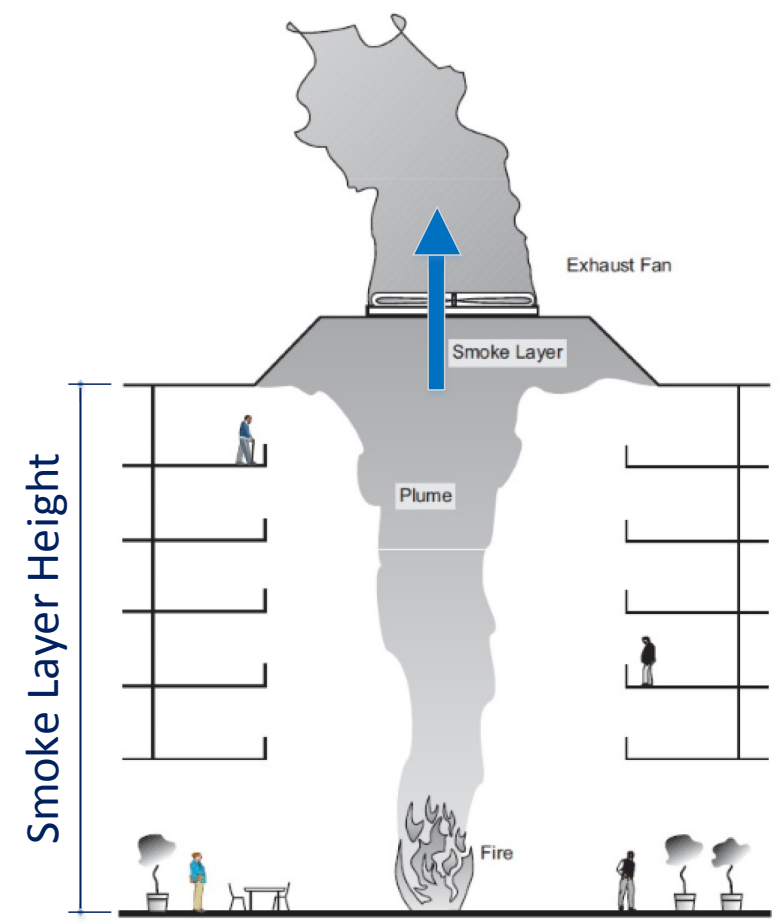

Figure 2-6 Mechanical smoke exhaust [modified from Lougheed, G. D. (2000)]

Pressurizing the non-smoke zones may provide sufficient pressure difference in order keep the smoke away from these zones. A considerable decrease in pressure difference may occur, due to window breakage or other existing large openings, which may render the pressurization system ineffective, allowing smoke to enter to the non-smoke zones.

Klote et al. (2012) proposed a method for analysis of the exhaust system. They assumed that:

1. The smoke management system only exhausts the smoke from the smoke layer.

2. The smoke exhaust is the only mass flow from the smoke layer.

3. The fire plume is the only mass flow that enters the smoke layer. 
4. The heat transfer between the hot upper layer and the cold lower layer has been achieved to the steady state condition.

5. The smoke layer height remains constant during the steady state condition.

6. The mass flow entering the smoke layer and the mass flow exhausting from the smoke layer is in steady state condition.

Then, Klote et al. (2012) proposed the equalization of mass flow rate entering plume and the mass flow rate of the exhaust system.

$$
\dot{m}_{p}=\dot{m}_{e}
$$

Where:

$\dot{m}_{e}=$ Mass flow rate of exhaust smoke, $\mathrm{kg} / \mathrm{s}$

The plume mass flow rate is given by Eq. 2-1.

\subsection{Make-up Air}

Make-up air enters the atrium from the openings to replace the smoke which is exhausting from the atrium. Sufficient opening area must be provided in the atrium to prevent pressure decrease in the atrium.

NFPA 92B and the SFPE guidelines for atrium design recommend that the make-up air velocity must be limited to $1 \mathrm{~m} / \mathrm{s}$. Also, it is recommended to locate the make-up air 
entries below the smoke layer height. The make-up air impacts on the smoke conditions in the atrium have been studied by several researchers.

\subsection{Previous Research Work}

\subsubsection{Measuring Smoke Layer Height}

Lougheed and Hadjisophocleous (1997) studied the effectiveness of smoke management systems by performing small-scale atrium experiments and conducting CFD modelling with considering 15, 25, 50, 150, 250, 300, 400, 500, 600 and $800 \mathrm{~kW}$ fire in a small atrium.

The results reflected a good agreement between the experimental data and the estimation of correlations in NFPA 92B. The results also indicated that the smoke management system is effective to exhaust the gasses from the lower layer when it operates near or just below the required capacity. When the exhaust system operates above the design flow rate, the fresh air from the cold lower layer enters the exhaust system. This does not disturb the performance of the smoke management system if the elevation of the smoke layer remains at an acceptable height.

Although the comparison of the CFD modelling results with the experimental data showed that the $\mathrm{CO}_{2}$ concentration and temperature do not exactly agree with the experimental data, the CFD modelling can roughly estimate the smoke layer height and average condition in the hot layer. 
From the temperature profiles measured at various heights in the test facility they realized that the hot layer temperature quickly reach to a steady state condition in the case of small fire. For the big fires with heat release rate greater than $200 \mathrm{~kW}$, the hot layer temperature did not reach a steady state condition due to the radiation from the fire, which produces some heating of the wall and the air in the lower level of the compartment. However, the upper layer reached a relatively steady condition when the temperature increase was minimal in the later stage of the test.

Hadjisophocleous et al. (2002) investigated the smoke layer height in small atrium fires. They conducted full-scale experiments of $15 \mathrm{~kW}$ to $600 \mathrm{~kW}$ fire in a $9 \mathrm{~m} \times 6 \mathrm{~m} \times 5 \mathrm{~m}$ atrium. The exhaust rate varied from 1.94 to $5.13 \mathrm{~kg} / \mathrm{s}$.

They compared the smoke interface height from the experimental results with the estimation of a two-zone model. The experimental results of the small to medium fires showed good agreement between the smoke layer height from the temperature profiles and $\mathrm{CO}_{2}$ concentrations. They also realized that the temperature profiles of larger fires yield lower smoke layer height than the smoke layer height deduced from the $\mathrm{CO}_{2}$ concentrations. In addition, the $\mathrm{CO}_{2}$ concentrations from experimental data were significantly lower than the simulation results. However, a good agreement was found between the recorded temperature from experiments and the predicted temperature from simulation results. 
Chow (2009) studied the effectiveness of N-percentage method in determining the smoke layer height. He considered several fire tests in five atriums with maximum height of $33 \mathrm{~m}$ and $2 \mathrm{MW}$ methane pool fire. A thermocouple tree with thermocouples at the interval of $2 \mathrm{~m}$ was employed to determine the smoke interface height. The smoke condition was visually observed to compare with the estimated height from the N-percentage method. Three values of $0.1,0.15$ and 0.2 were considered by Chow for the $\mathrm{N}$ value in this method.

He concluded that the N-percentage method is very suitable in deducing the smoke interface height, as it is very difficult to determine the smoke layer height in tall atria with irregular shape by visual observation. The higher $\mathrm{N}$ values calculate higher elevation for the smoke layer.

The uncertainty of the Chow's test was relatively high, as the thermocouples had an interval of $2 \mathrm{~m}$ in the thermocouple tree. Therefore, a shorter interval by more thermocouples in the thermocouple tree yields more accurate results.

\subsubsection{Effects of Make-up Air Velocity and Opening Arrangement}

Heskestad (1986) and Mudan and Croce (1995) recommended a $1 \mathrm{~m} / \mathrm{s}$ limitation for make-up air velocity. They stated that air velocities higher than $1 \mathrm{~m} / \mathrm{s}$ disturb the smoke plume and cause the interface height to decrease. 
As stated earlier, the NFPA 92B (2009) restricts the supply air velocity to $1 \mathrm{~m} / \mathrm{s}$. The mass flow rate of the air entering the atrium should be equal to the mass flow rate of the smoke exhausting from the atrium. The supply air, which enters the atrium below the smoke layer, may be provided naturally through the openings in the atrium or by using supply fans.

One of the approaches to provide make-up air to the atrium is the natural supply which allows the atrium to draw in air through the openings as soon as the smoke management system operates. The exterior opening may automatically open when the exhaust system activates.

In some cases where the atrium does not have enough access to the outside of the building, a mechanical system may be needed to provide fresh air. Although this method is a good replacement for the natural supply in specific cases, it is difficult to maintain a constant air velocity.

The mechanical smoke management system with natural supply has been considered by several designers in recent years. Klote et al. (2012) recommended that the supply fresh air meet the following requirement:

- The make-up air must not be polluted with smoke.

- The make-up air must enter the atrium below the smoke layer.

- The make-up air must enter the atrium with low velocity. 
- The make-up air flow rate must be less than the exhaust rate of the smoke management system.

The effect of the make-up air entry elevation on the performance of smoke management systems was studied by Yi et al. (2004) by conducting experiments and using a zone model. The opening location was considered to be below, above and within the smoke interface height.

They realized that make-up air entry below the smoke layer height causes minimal turbulence on the smoke conditions in the atrium and results in minimal decrease of the smoke layer height. The make-up air entry located above the smoke layer causes the fresh air to be mixed with the smoke right after entering the atrium. In this situation the smoke layer height decreases significantly. In addition, the smoke layer temperature reduces due to the mixing of smoke and fresh air. Locating openings at the interface height reduces the smoke layer temperature and decreases the smoke layer height compared to the case of locating openings below the interface height. They also found good agreement between the prediction of the zone model and the experimental results.

The impact of higher make-up air velocities on the smoke layer height was investigated by Souza and Milke (2004). They simulated a 30-m atrium with a 3 MW fire using FDS 3.0. They considered symmetric and asymmetric opening arrangements with $0.5,1,1.5$ and $3 \mathrm{~m} / \mathrm{s}$ air velocity. They realized that make-up air velocities up to $1.5 \mathrm{~m} / \mathrm{s}$ in 
symmetric opening arrangements do not cause a big change in the smoke interface height.

They also noticed that an asymmetric opening arrangement in the atrium with air velocity below $1.5 \mathrm{~m} / \mathrm{s}$ causes a small change in the smoke layer height. However, air velocities higher than $1.5 \mathrm{~m} / \mathrm{s}$ disturb the smoke movement and cause a big decrease in the smoke layer height.

Zhou (2006) also evaluated the effect of make-up air velocity on smoke layer height by simulating 1, 2.5 and $5 \mathrm{MW}$ fires exposed to $0.5,1.0,1.25,1.5 \mathrm{~m} / \mathrm{s}$ make-up air velocities in a large number of atrium heights from 10 to $60 \mathrm{~m}$. The computer model Fire Dynamics Simulator (FDS) was used to model the fire, the exhaust system and to predict the smoke conditions in the atrium.

In the region around the fire, the CFD modeling results showed that FDS is sensitive to the grid size. However, the results of medium grid size around $0.25 \mathrm{~m}$ were similar to a finer grid size of around $0.125 \mathrm{~m}$ in the regions away from the fire.

In addition to this, she used FDS to investigate the effect of air velocity on flames. The results indicated that FDS is capable of modeling the effect of air velocity on the plume. Moreover, the velocity of $1 \mathrm{~m} / \mathrm{s}$ caused minimal flame tilt in all simulated fire sizes. She concluded that the effects of air velocity on the plume of small fires are more 
pronounced than the effects on the plume of big fires. However, higher velocities disturb the fire plume significantly.

She also evaluated the effect of opening height on the plume of fire in an atrium. The results showed the minimal plume disturbance occurred by locating the opening at the bottom and top of the atrium. Locating opening at the mid-height of the atrium caused the largest plume disruption.

The following conclusions were drawn from the evaluation of the make-up air velocity on the smoke condition for different fire sizes and fire location in an atrium:

- The effect of make-up air velocity on the smoke conditions is more pronounced in short atria with the heights less than $20 \mathrm{~m}$.

- The $1 \mathrm{~m} / \mathrm{s}$ make-up air velocity does not make turbulence in smoke condition and is too restrictive in most cases.

- The $1.25 \mathrm{~m} / \mathrm{s}$ air velocity might be considered to increase the make-up air velocity limit, as it produces similar results to the $1.0 \mathrm{~m} / \mathrm{s}$ air velocity.

Zhou's research did not evaluate the impact of make-up air for the cases where the fire is located at the center of the atrium.

The CFD modeling was used by Kerber and Milke (2007) to investigate the effect of make-up air velocity and opening arrangement on the smoke conditions in an atrium. 
The air velocities of $0.5,1.0,2.0$ and $3.0 \mathrm{~m} / \mathrm{s}$ were considered for this research. They also considered a symmetric opening arrangement, asymmetric opening arrangement and an array of the opening distributed over the height of the atrium. In total, they simulated ten scenarios in a $30.5-\mathrm{m}$ high atrium with a stack of pallets as a fire source with maximum $5 \mathrm{MW}$ heat release rate.

The results indicated that the make-up air velocity of 0.5 and $1 \mathrm{~m} / \mathrm{s}$ in the case of symmetric opening arrangement and $1 \mathrm{~m} / \mathrm{s}$ air velocity in the case of one opening per floor are able to meet the design smoke layer height which is predicted by correlations. They also observed that the $2 \mathrm{~m} / \mathrm{s}$ air velocity in symmetric opening arrangement causes disruption in smoke condition and decrease the smoke layer height.

They concluded that the symmetric opening arrangement is the best way to provide air to the atrium, if the fire is considered to be at the center of the atrium. Moreover, the openings should be configured to prevent the fire plume to rotate, as the rotational make-up air causes a significant disturbance in the smoke conditions and results in big decrease in smoke layer height. The rotational airflow was the worst case in the simulated scenarios.

NFPA 92B prevents locating the opening at the expected smoke layer height, as the air may introduce directly to the smoke layer and decrease the smoke layer to a height below the design level. Kerber and Milke also studied the impact of locating the opening at the expected height of the smoke layer by simulating an arrangement of one opening per floor. The simulation results showed that the arrangement of one opening 
per floor yields the similar results as the results of symmetric opening below the smoke layer.

Gutierrez-Montes C., Sanmiguel-Rojas E. et al. (2009) conducted three full-scale experiment to evaluate the impact of make-up air velocity, opening area and the location of opening on the smoke condition in a $20 \mathrm{~m}^{3}$ atrium. They also simulated the experiments with FDS4 in order to compare with experimental data.

They also simulated the experiments with FDS4 in order to compare with experimental data. These tests were conducted in an atrium with four-exhaust fans on the ceiling and a heptane pool fire of $0.92 \mathrm{~m}$ diameter, which was located at the center of the atrium. The first test was carried out with a non-symmetric opening arrangement with $97.5 \mathrm{~m}^{2}$ opening area. The second test was conducted with symmetric opening arrangement and half of the opening area of the first test $\left(48.75 \mathrm{~m}^{2}\right)$. The third test considered the same opening arrangement as the second test, which the openings were partially open to $22 \%$ of the area in the second test $\left(10.83 \mathrm{~m}^{2}\right)$.

In test \#1 and \#2 the make-up air velocity was much lower than $1 \mathrm{~m} / \mathrm{s}$ (average value around 0.2 to $0.5 \mathrm{~m} / \mathrm{s}$ ) due to the large opening area. Although the velocity of make-up air was within the recommended values, the large opening area cussed that the flames and fire plume to be more sensitive to the outer effects. Moreover, the lack of symmetry in the opening arrangement increased the turbulence of flames and fire plume. 
In tests $\# 3$, higher velocities of $1 \mathrm{~m} / \mathrm{s}$ were measured, as the opening area was smaller than the opening area in test \#1 and \#2. It was observed that the fire plume and smoke conditions in the far field did not get affected by the higher make-up air velocity in test \#3. They concluded that the higher make-up air velocity than $1 \mathrm{~m} / \mathrm{s}$ does not always cause a significant disturbance in the atrium smoke conditions.

They also realized that the FDS well-predicts the air velocity at the wall opening. Although in the case of air velocity lower than $1 \mathrm{~m} / \mathrm{s}$, FDS well-predicts the smoke condition at the upper part of the far field, it under estimates the temperature in the lower layer and thus, slightly over estimates the final smoke interface height. In addition, a poor agreement was found between the experimental data and the simulation results in the case of make-up air velocity higher than $1 \mathrm{~m} / \mathrm{s}$. Also, FDS over predicts the effect of make-up air on the plume turbulence. They reported that the numerical perturbation within the model enhances the mixing of smoke layer with the fresh air in the lower layer, homogenizes the smoke layer and decreases the smoke interface height. This causes a relative error larger than $20 \%$ compared to the experimental results.

Gutierrez-Montes et al. concluded that the additional fire test and CFD modelling should be conducted varying make-up air conditions and heat release rate of fire in order to evaluate the FDS predictions in simulating the atrium smoke conditions and its performance for the design of smoke management systems in atria. 


\subsubsection{Effects of Make-up Air Velocity and Opening Arrangement}

Dohim R. M., Yohanis Y. G. et al. (2014) investigated the effect of atrium shape on the smoke ventilation performance in naturally ventilated atria. They considered three different configurations including square, rectangular and triangular shape with a same height, area and hence volume. CFD modeling was used to investigate the performance of smoke ventilation in terms of smoke filling time. They used FDS to simulate the natural smoke filling resulting from an atrium fire in those three configurations. The smoke layer interface height, soot mass fraction and temperature as a function of height were recorded during the simulations. All other parameters including fire size, fire location and inlet and outlet area were designed to be similar throughout the modelling in order to test sensitivity of the atrium shape.

They realized that better contribution in smoke ventilation design is provided by the rectangular atrium configuration than square and triangular configurations, as it is able to maintain a clear height for a longer time, with the least amount of soot mass fraction. In addition, they figured out that the triangular shape is the worst case due to the highest temperature in the smoke layer, the highest soot mass fraction and therefore lower smoke layer height.

Ayala P., Cantizano A. et al. (2013) studied the effect of ceiling geometry on the smoke layer in naturally ventilated atrium by conducting numerical modelling. They used FDS $\mathrm{v} 4$ and v5 to simulate atrium fires with maximum size of 1.36 MW and 2.34 MW inside

a $20 \mathrm{~m}^{3}$ atrium with four different ceiling geometries. In addition, they studied the 
effect of atrium aspect ratio $\left(\mathrm{A} / \mathrm{H}^{2}\right)$ on the smoke interface height in naturally ventilated atrium.

They found no significant difference in smoke layer heights and temperature estimations for different ceiling geometries. Also, the results showed that the atrium aspect ratio $\left(\mathrm{A} / \mathrm{H}^{2}\right)$ does not have significant effect on the simulation results. Moreover, a difference of $14 \%$ in predicting temperature was observed between the results of FDS v4 and FDS v5, as the FDS v4 estimate higher temperature within the model. They concluded that the ceiling geometry and the atrium shape do not have any significant impact on the far field temperature in the atrium. Therefore, an atrium with a simple geometry is suitable for design purposes. 


\section{Chapter 3: Full-Scale Experiments}

\subsection{Carleton University Fire Lab}

Carleton University has a large fire research laboratory in Almonte, Ontario, Canada. It has a $25 \mathrm{~m}$ high atrium, a burn hall and a $37.5 \mathrm{~m}$ long tunnel for carrying out full-scale experiments. This fire lab is adjacent to the fire research facilities of the National Research Council of Canada. This facility is equipped with three fans located on top of the tunnel which can exhaust gases at a maximum rate of $95000 \mathrm{cfm}(44 \mathrm{~m} / \mathrm{s})$ each. Two fans are on the fan chamber level and one fan is on the attic level. The smoke management system is capable of exhausting smoke from both the atrium and the tunnel via a large duct chamber which is connected to each facility.

The atrium is approximately $20 \mathrm{~m}$ long by $20 \mathrm{~m}$ wide by $25 \mathrm{~m}$ high. The ceiling has six $3.5-\mathrm{m}^{2}$ openings in order to exhaust the smoke to the duct. The tunnel measures 37.5 long by $10 \mathrm{~m}$ wide and $5.6 \mathrm{~m}$ high and the burn hall is $20 \mathrm{~m}$ long by $20 \mathrm{~m}$ wide by 12.5 m high. Figure 3-1 shows a photo of Carleton University Fire Lab and the NRC Fire Lab. 


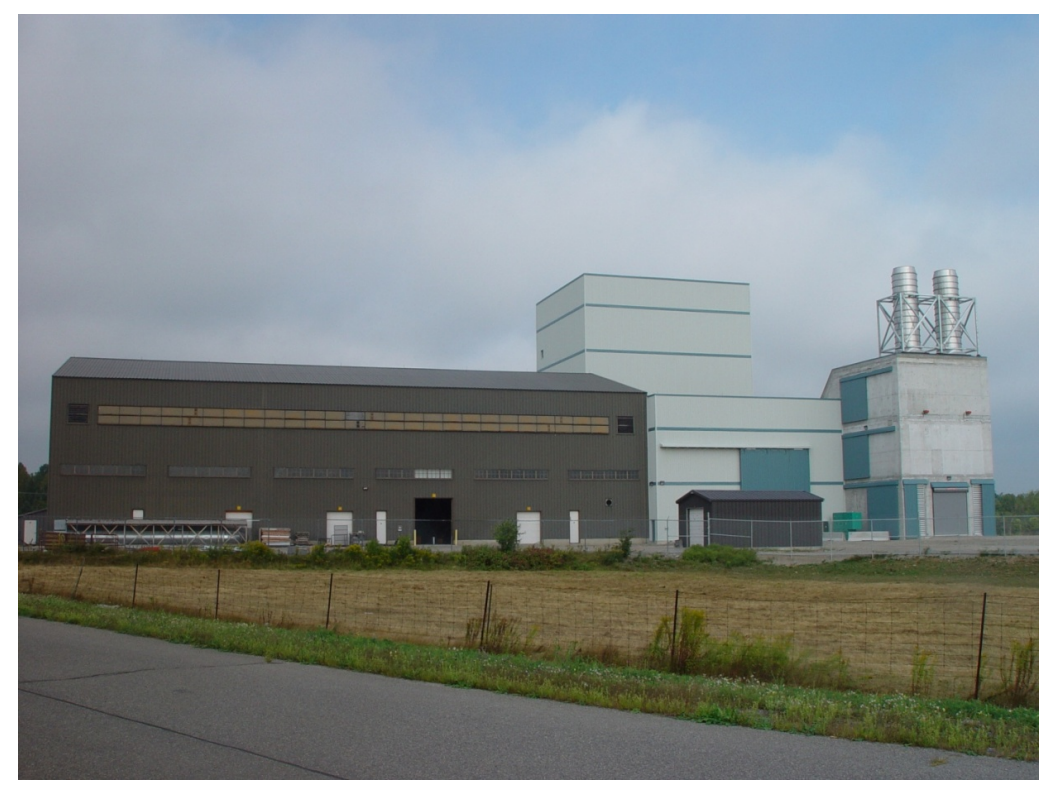

Figure 3-1 Photo of Carleton University facility

Atrium height is one of the most important parameters affecting smoke exhaust flow rate. This can be seen in correlations of entrainment rates, Eq. 2-1, in which the height of the smoke layer is raised to the power of $5 / 3$, while the fire size is raised to the power of $1 / 3$. The higher the smoke layer the larger the amount of makeup air required. In this research, Carleton University Fire Lab's atrium is used for full-scale experiments as a simple, rectangular atrium with a 25-m height.

\subsection{Instrumentation}

Carleton University's atrium is equipped to perform full-scale tests to investigate the impact of make-up air velocities on the fire plume and the interface height. To provide visual observations of the development of the smoke layer, a $25 \mathrm{~m}$ long measuring tape has been installed in the atrium from floor to ceiling and three different video cameras have been employed to record the smoke height. Also four thermocouple trees have 
been installed with 25 thermocouples each. The thermocouple trees have been placed at different locations around the fire. Propane is used for the atrium fire tests and the propane flow rate was recorded during the experiments. Figure 3-2 illustrates the location of thermocouples in the atrium and Figure 3-3 and 3-4 show photos of the equipped atrium.

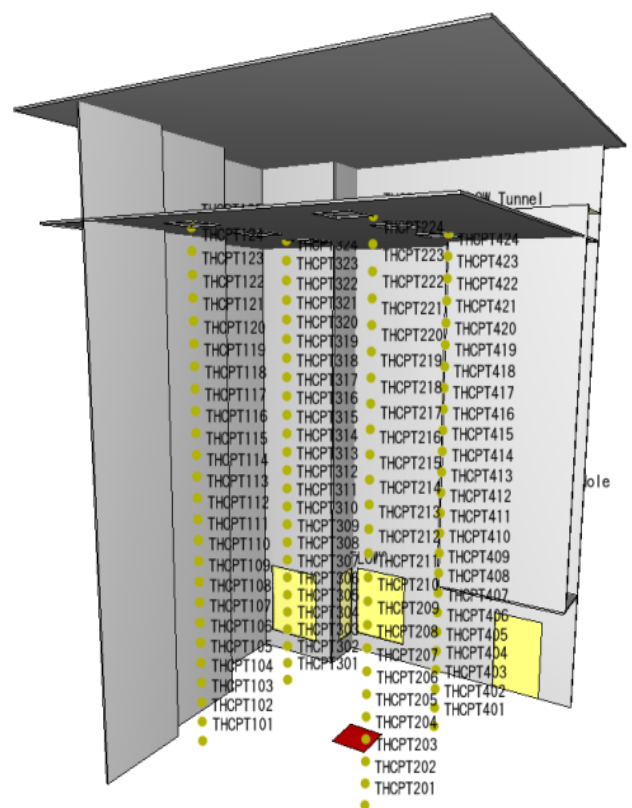

Figure 3-2 Location of thermocouple trees in the atrium

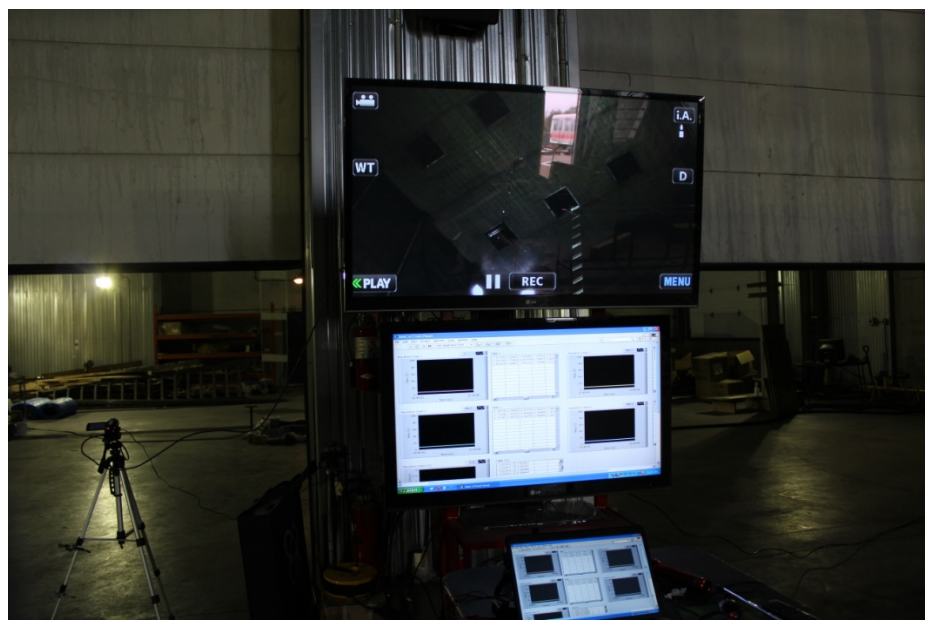

Figure 3-3 Data recording equipment in Carleton University Fire Lab 


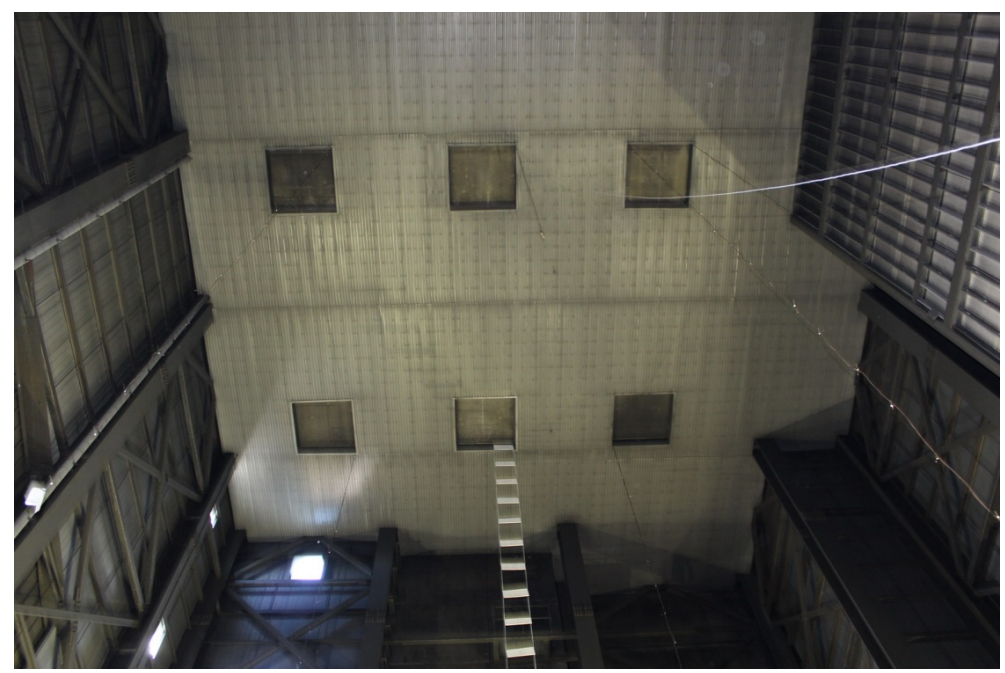

Figure 3-4 Carleton University equipped atrium for fire tests

\subsection{Smoke Layer Height Estimation}

\subsubsection{Smoke Layer Height Estimation Using Correlations}

One of the methods used to estimate the average temperature and smoke layer interface height for a specific heat release rate and smoke exhaust rate is based on a mass balance in the hot layer, where the mass flow rate of the plume into the hot layer is set equal to the mass flow rate of the exhaust system (Klote et al., 2012).

$$
\begin{gathered}
\dot{m}_{p}=\dot{m}_{\text {exh }} \\
\dot{m}_{p}=0.071 \dot{Q}_{c}{ }^{1 / 3} z^{5 / 3}+0.0018 \dot{Q}_{c}
\end{gathered}
$$

The average smoke layer temperature is given by:

$$
T_{s}=T_{a}+\frac{\dot{Q}_{c}}{\dot{m}_{p} C_{p}}
$$


Where:

$\mathrm{T}_{\mathrm{s}}=$ Temperature of the smoke layer, ${ }^{\circ} \mathrm{C}$

$\mathrm{c}_{\mathrm{p}}=$ Specific heat of smoke, $\mathrm{kJ} / \mathrm{kg}^{\circ} \mathrm{C}$

The volumetric smoke flow into the upper layer is calculated by:

$$
\dot{V}_{e x h}=\frac{\dot{m}_{p}}{\rho_{s}}
$$

Where:

$\dot{V}_{\text {exh }}=$ Volumetric flow rate of the exhaust gases, $\mathrm{m}^{3} / \mathrm{s}$

$\rho_{s}=$ Density of the smoke layer, $\mathrm{kg} / \mathrm{m}^{3}$

Which is:

$$
\rho_{s}=\frac{353}{T_{s}}
$$

\subsubsection{Smoke Height Measuring Method in Experiments}

The N-Percentage method has been applied to determine the smoke layer height when the boundary between the smoke layer and the lower layer was not clear. The NPercentage method uses recorded temperatures at different heights during the test and Eq. 2-19 to determine the smoke layer height with an $\mathrm{N}$ value of 0.2 . As stated earlier, each thermocouple tree contains 25 thermocouples which are located at every meter along the height of atrium. Due to the interval of $1 \mathrm{~m}$, the results of smoke layer height from the N-percentage method have an uncertainty of $\pm 1 \mathrm{~m}$ in the 25 -m high atrium. In other words, the uncertainty of the experimental smoke layer height is $\pm 4 \%$ of the atrium height. 


\subsection{Problem Statement}

To provide an appreciation of the problem, Table 3-1 shows mass flow rates and opening areas required for three different fire heat release rates and 5 smoke layer heights for a $25-\mathrm{m}$ tall atrium with a fire $1 \mathrm{~m}$ above the ground. The area of the opening was computed using an inlet velocity of $1 \mathrm{~m} / \mathrm{s}$, and the length of the opening was calculated assuming an opening height of $3 \mathrm{~m}$. As Table 3-1 shows, even for the small fire, the tall atrium requires very large openings to keep the smoke at a safe level and supply air at $1 \mathrm{~m} / \mathrm{s}$.

Table 3-1 Mass flow rates and required areas for a velocity of $1 \mathrm{~m} / \mathrm{s}$ and an opening height of $3 \mathrm{~m}$

\begin{tabular}{lcccc}
\hline HRR & $\begin{array}{c}\text { Smoke layer } \\
(\mathbf{M W})\end{array}$ & $\begin{array}{c}\text { Mass flow } \\
\text { Height }(\mathbf{m})\end{array}$ & $\begin{array}{c}\text { Area of opening } \\
\text { rate } \mathbf{k g} / \mathbf{s})\end{array}$ & $\begin{array}{c}\text { Length of } \\
\left(\mathbf{m}^{\mathbf{2}}\right)\end{array}$ \\
\hline 5 & 25.00 & 215.48 & 180 & 60 \\
5 & 20.00 & 148.07 & 123 & 41 \\
5 & 15.00 & 91.24 & 76 & 25.33 \\
5 & 10.00 & 47.35 & 40 & 13.33 \\
5 & 5.00 & 16.57 & 14 & 4.66 \\
\hline 2 & 25.00 & 157.39 & 130 & 43.33 \\
2 & 20.00 & 107.35 & 90 & 30 \\
2 & 15.00 & 65.51 & 55 & 18.33 \\
2 & 10.00 & 32.36 & 27 & 9 \\
2 & 5.00 & 10.26 & 9 & 3 \\
\hline 1 & 25.00 & 123.13 & 102 & 34 \\
1 & 20.00 & 84.45 & 71 & 23.67 \\
1 & 15.00 & 51 & 43 & 14.3 \\
1 & 10.00 & 25.25 & 21 & 7 \\
1 & 5.00 & 7.57 & 6 & 2 \\
\hline
\end{tabular}


Because of the uncertainty in using correlations for determining the smoke layer height, several full-scale tests have been carried out in parallel with conducting CFD modelling to gain an understanding of the mechanisms of smoke flow in atrium when an air flow impacts the smoke plume.

\subsection{Full-Scale Tests}

Seventy-two full-scale fire tests have been performed to investigate the effect of makeup air on the smoke conditions in the atrium for 1, 2 and $5 \mathrm{MW}$ fire heat release rates. For each test the atrium conditions were allowed to reach steady state and remain at steady state for a short period of time. Following that, the make-up air velocity was increased as required by the next test and allowed to stabilise until steady state again. Figure 3-5 and 3-6 show photos of the atrium during the test.

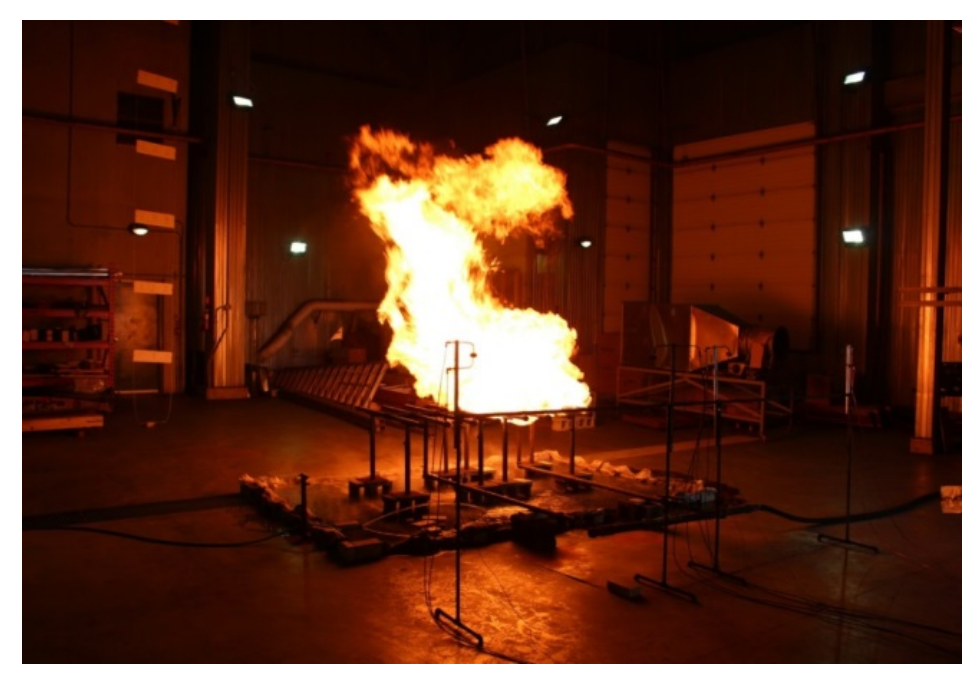

Figure 3-5 Test start 


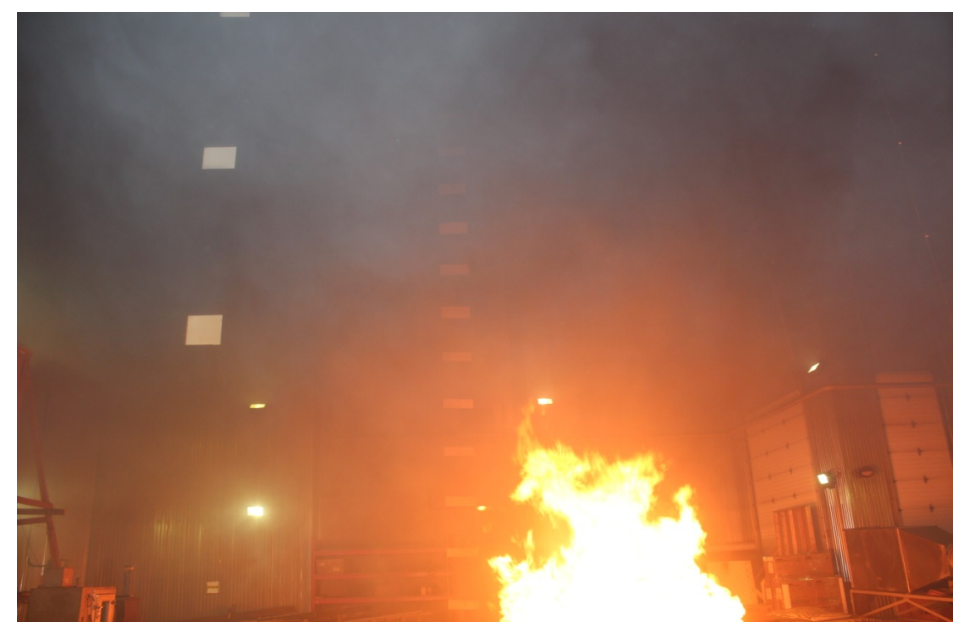

Figure 3-6 Steady condition in atrium fire test

Due to the unclear boundary between the smoke layer and the lower layer, the NPercentage method (Cooper et al., 1982) has been used to determine the smoke layer height using the experimental temperature profiles. During the experiments the smoke and plume movement have been observed and recorded by three video cameras in order to compare the visually observed hot layer height to the one computed using the $\mathrm{N}$ Percentage method. Figure 3-7 shows a photo of the atrium during a test, which demonstrates that the interface between the lower and the upper smoke layer is not well defined. 


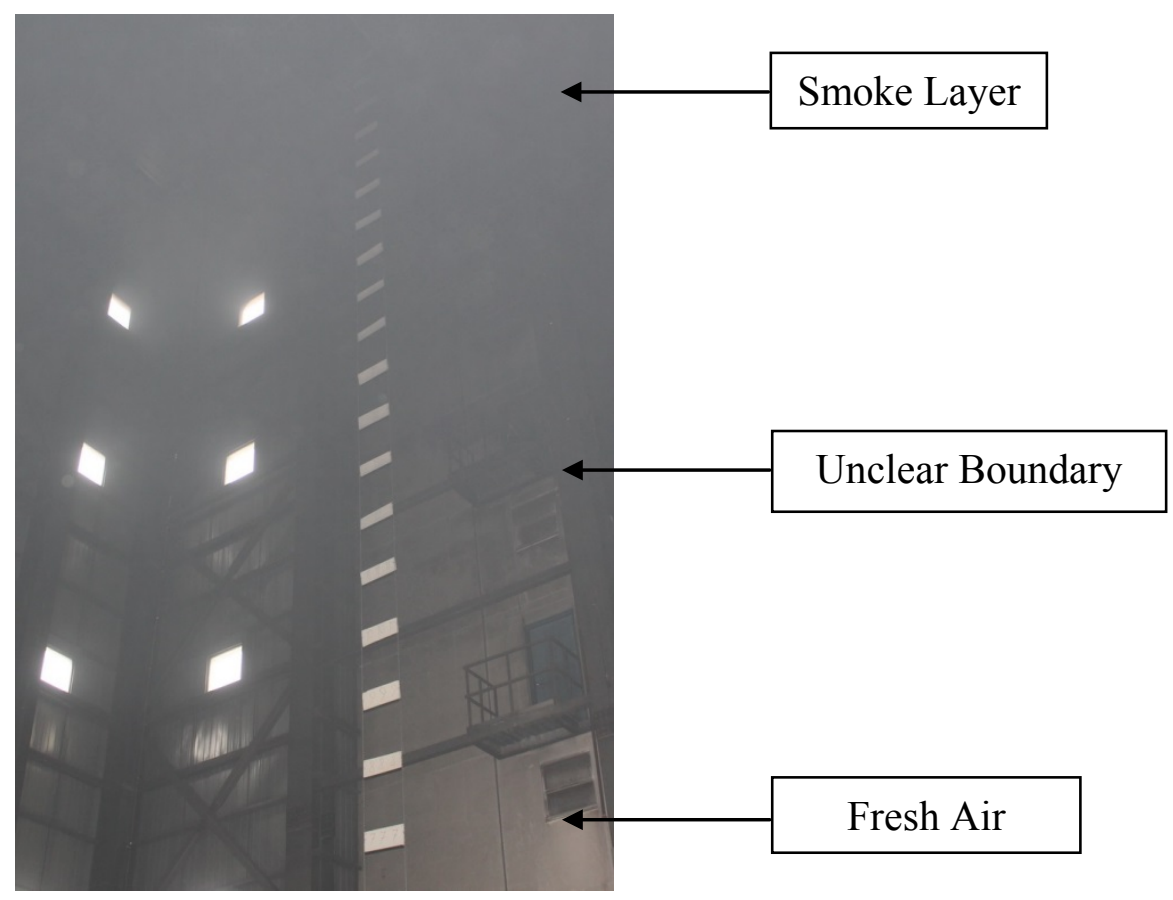

Figure 3-7 Smoke conditions

\subsection{Experimental Plan}

Table 3-2 shows the main parameters that have an impact on fire plume behavior and potential values that may be used. As discussed above, air velocities and opening conditions are the most important parameters that govern the entrainment rates, followed by the fire size. Therefore fire sizes are considered from 1-5 MW and air velocities vary from 1.00 to $2.00 \mathrm{~m} / \mathrm{s}$. Sixty-three full-scale experiments have to be conducted to consider all potential values shown in Table 3-2. Table 3-3 shows the proposed experiment plan. 
Table 3-2 Variables involved and potential values

\begin{tabular}{cccccc}
\hline Variable & Value 1 & Value 2 & Value 3 & Value 4 & Value 5 \\
\hline Fire Size (MW) & $\mathbf{1}$ & $\mathbf{2}$ & $\mathbf{5}$ & - & - \\
\hline $\begin{array}{c}\text { Make-up air } \\
\text { velocity (m/s) }\end{array}$ & $\mathbf{1 . 0}$ & $\mathbf{1 . 5}$ & $\mathbf{2}$ & - & - \\
\hline $\begin{array}{c}\text { Opening } \\
\text { arrangement }\end{array}$ & 4-sides & $\begin{array}{c}\text { 2-opposite } \\
\text { sides }\end{array}$ & 3-sides & 2-adjacent & 1-side \\
\hline $\begin{array}{c}\text { Air flow } \\
\text { direction }\end{array}$ & Direct air & Rotational air & - & sides & \\
\hline
\end{tabular}

Table 3-3 Test plan

\begin{tabular}{|c|c|c|c|c|}
\hline $\begin{array}{c}\text { Experiment } \\
\text { Number }\end{array}$ & $\begin{array}{c}\text { Fire Size } \\
(\mathrm{MW})\end{array}$ & $\begin{array}{c}\text { Air Velocity } \\
(\mathrm{m} / \mathrm{s})\end{array}$ & $\begin{array}{c}\text { Opening } \\
\text { arrangement }\end{array}$ & $\begin{array}{l}\text { Air flow } \\
\text { direction }\end{array}$ \\
\hline 1 & 1 & 1 & - & - \\
\hline 2 & 1 & 1.5 & - & - \\
\hline 3 & 1 & 2 & - & - \\
\hline 4 & 2 & 1 & - & - \\
\hline 5 & 2 & 1.5 & - & - \\
\hline 6 & 2 & 2 & - & - \\
\hline 7 & 5 & 1 & - & - \\
\hline 8 & 5 & 1.5 & - & - \\
\hline 9 & 5 & 2 & - & - \\
\hline 10 & 1 & 1 & 4-sides & - \\
\hline 11 & 1 & 1 & $\begin{array}{c}\text { 2-opposite } \\
\text { sides }\end{array}$ & - \\
\hline 12 & 1 & 1 & 3-sides & - \\
\hline 13 & 1 & 1 & $\begin{array}{l}\text { 2-adjacent } \\
\text { sides }\end{array}$ & - \\
\hline
\end{tabular}




\begin{tabular}{|c|c|c|c|c|}
\hline 14 & 1 & 1 & 1 -side & \\
\hline 15 & 1 & 1.5 & 4-sides & \\
\hline 16 & 1 & 1.5 & $\begin{array}{l}\text { 2-opposite } \\
\text { sides }\end{array}$ & \\
\hline 17 & 1 & 1.5 & 3-sides & \\
\hline 18 & 1 & 1.5 & $\begin{array}{l}\text { 2-adjacent } \\
\text { sides }\end{array}$ & \\
\hline 19 & 1 & 1.5 & 1-side & \\
\hline 20 & 1 & 2 & 4-sides & \\
\hline 21 & 1 & 2 & $\begin{array}{l}\text { 2-opposite } \\
\text { sides }\end{array}$ & \\
\hline 22 & 1 & 2 & 3-sides & \\
\hline 23 & 1 & 2 & $\begin{array}{l}\text { 2-adjacent } \\
\text { sides }\end{array}$ & \\
\hline 24 & 1 & 2 & 1-side & \\
\hline 25 & 2 & 1 & 4-sides & - \\
\hline 26 & 2 & 1 & $\begin{array}{l}\text { 2-opposite } \\
\text { sides }\end{array}$ & - \\
\hline 27 & 2 & 1 & 3-sides & - \\
\hline 28 & 2 & 1 & $\begin{array}{l}\text { 2-adjacent } \\
\quad \text { sides }\end{array}$ & - \\
\hline 29 & 2 & 1 & 1 -side & - \\
\hline 30 & 2 & 1.5 & 4-sides & \\
\hline 31 & 2 & 1.5 & $\begin{array}{c}\text { 2-opposite } \\
\text { sides }\end{array}$ & \\
\hline 32 & 2 & 1.5 & 3-sides & \\
\hline 33 & 2 & 1.5 & $\begin{array}{l}\text { 2-adjacent } \\
\quad \text { sides }\end{array}$ & \\
\hline 34 & 2 & 1.5 & 1 -side & \\
\hline 35 & 2 & 2 & 4-sides & \\
\hline 36 & 2 & 2 & $\begin{array}{l}\text { 2-opposite } \\
\text { sides }\end{array}$ & \\
\hline
\end{tabular}




\begin{tabular}{|c|c|c|c|c|}
\hline 37 & 2 & 2 & 3-sides & \\
\hline 38 & 2 & 2 & $\begin{array}{l}\text { 2-adjacent } \\
\text { sides }\end{array}$ & \\
\hline 39 & 2 & 2 & 1 -side & \\
\hline 40 & 5 & 1 & 4-sides & - \\
\hline 41 & 5 & 1 & $\begin{array}{c}\text { 2-opposite } \\
\text { sides }\end{array}$ & - \\
\hline 42 & 5 & 1 & 3-sides & - \\
\hline 43 & 5 & 1 & $\begin{array}{c}\text { 2-adjacent } \\
\text { sides }\end{array}$ & - \\
\hline 44 & 5 & 1 & 1 -side & - \\
\hline 45 & 5 & 1.5 & 4-sides & \\
\hline 46 & 5 & 1.5 & $\begin{array}{c}\text { 2-opposite } \\
\text { sides }\end{array}$ & \\
\hline 47 & 5 & 1.5 & 3-sides & \\
\hline 48 & 5 & 1.5 & $\begin{array}{l}\text { 2-adjacent } \\
\text { sides }\end{array}$ & \\
\hline 49 & 5 & 1.5 & 1 -side & \\
\hline 50 & 5 & 2 & 4-sides & \\
\hline 51 & 5 & 2 & $\begin{array}{c}\text { 2-opposite } \\
\text { sides }\end{array}$ & \\
\hline 52 & 5 & 2 & 3-sides & \\
\hline 53 & 5 & 2 & $\begin{array}{l}\text { 2-adjacent } \\
\text { sides }\end{array}$ & \\
\hline 54 & 5 & 2 & 1 -side & \\
\hline 55 & 1 & 1 & - & $\begin{array}{c}\text { rotational } \\
\text { make-up air }\end{array}$ \\
\hline 56 & 1 & 1.5 & - & $\begin{array}{l}\text { rotational } \\
\text { make-up air }\end{array}$ \\
\hline 57 & 1 & 2 & - & $\begin{array}{c}\text { rotational } \\
\text { make-up air }\end{array}$ \\
\hline 58 & 2 & 1 & - & $\begin{array}{c}\text { rotational } \\
\text { make-up air }\end{array}$ \\
\hline
\end{tabular}




\begin{tabular}{|c|c|c|c|c|}
\hline 59 & 2 & 1.5 & - & $\begin{array}{c}\text { rotational } \\
\text { make-up air }\end{array}$ \\
\hline 60 & 2 & 2 & - & $\begin{array}{c}\text { rotational } \\
\text { make-up air }\end{array}$ \\
\hline 61 & 5 & 1 & - & $\begin{array}{c}\text { rotational } \\
\text { make-up air }\end{array}$ \\
\hline 62 & 5 & 1.5 & - & $\begin{array}{c}\text { rotational } \\
\text { make-up air }\end{array}$ \\
\hline 63 & 5 & 2 & - & $\begin{array}{c}\text { rotational } \\
\text { make-up air }\end{array}$ \\
\hline
\end{tabular}




\section{Chapter 4: Modelling}

\subsection{CFD Modelling}

Computational Fluid Dynamics (CFD) is one of the most popular numerical methods in Fire Safety Engineering to simulate smoke movement. The concept of CFD modeling is based on dividing the computational domain to a finite number of control volumes in order to solve the equations for each control volume and combine the results of all control volume for the entire computational domain. The mass, momentum and energy conservation equations are solved by the CFD model.

\subsection{Fire Dynamics Simulator}

Fire Dynamics Simulator (FDS) (McGrattan et al., 2010) is one of the most common CFD models which is used extensively by several researchers, as it is able to model fires in any type of buildings including compartments, atria and tunnels.

FDS uses the Large Eddy Simulation (LES) approach as the default method of modeling. This method does not need a very fine grid size to capture the mixing and chemical reactions in the model. FDS is also able to use the Direct Numerical Simulation (DNS) approach; however it requires a sufficiently fine grid size.

The LES concepts are based on the turbulent mixing of the fuel and combustion gasses with the air which surrounds the fire. The fluid dynamics equations are able to reasonably calculate the large eddies which drive the mixing chemical reactions. 
The transport of mass, momentum and energy conservation equations are as follows (McGrattan et al., 2007):

Conservation of mass (species):

$$
\frac{\partial}{\partial t}\left(\rho Y_{i}\right)+\nabla \cdot \rho Y_{i} \boldsymbol{u}=\nabla \cdot \rho D_{i} \nabla Y_{i}+\dot{m}_{i}^{\prime \prime \prime}+\dot{m}_{b, i}^{\prime \prime \prime}
$$

Conservation of momentum:

$$
\frac{\partial}{\partial t}(\rho \boldsymbol{u})+\nabla \cdot \rho \boldsymbol{u u}+\nabla p=\rho g+f_{b}+\nabla \cdot \tau_{i j}
$$

Conservation of Energy:

$$
\frac{\partial}{\partial t}(\rho h)+\nabla \cdot \rho h \boldsymbol{u}=\frac{D_{p}}{D_{t}}+\dot{q}^{\prime \prime \prime}-\dot{q}_{b}^{\prime \prime \prime}-\nabla \cdot \dot{q}^{\prime \prime}+\varepsilon
$$

Where,

$$
\begin{array}{ll}
\boldsymbol{u}=(u, v, w) & =\text { Velocity Vector, } \mathrm{m} / \mathrm{s} \\
\rho & =\text { Gas density, } \mathrm{kg} / \mathrm{m}^{3} \\
p & =\text { Pressure, } \mathrm{Pa} \\
f_{b} & =\text { External force vector (excluding gravity), } \mathrm{N} \\
\tau_{i j} & =\text { Viscous stress tensor, Pa } \\
h & =\text { Enthalpy, } \mathrm{J} \\
Y_{i} & =\text { Mass fraction of } i \text { th species, } \mathrm{g} / \mathrm{g} \\
D_{i} & =\text { Diffusion of } i \text { th } \mathrm{species}, \mathrm{m}^{2} / \mathrm{s} \\
\dot{m}_{i}^{\prime \prime \prime} & =\text { Production rate of } i \text { th species per unit volume, } \mathrm{kg} / \mathrm{m}^{3} . \mathrm{s}
\end{array}
$$




$$
\begin{array}{ll}
\dot{q}^{\prime \prime \prime} & =\text { Heat release rate per unit volume, } \mathrm{kW} / \mathrm{m}^{3} \\
\dot{q}^{\prime \prime} & =\text { Heat flux vector } \\
\varepsilon & =\text { Dissipation rate, } \mathrm{J} / \mathrm{kg} . \mathrm{s}
\end{array}
$$

The mixture fraction combustion model calculates the fuel and oxygen diffusion throughout the domain. The mixture fraction model is based on the assumption that the mixing of fuel and oxygen controls the combustion process. It assumes that the fuel and oxygen cannot co-exist at the same time in a control volume. Therefore, only one parameter represents the combustion species in a control volume. The mixture fraction parameter is represented by $\mathrm{Z}(\mathrm{x}, \mathrm{t})$ within the model, which depends on the space $\mathrm{x}$ and time $t$. All of the species will be described as a function of $Z$ within the model. The fuel and oxygen concentration are described by the mixture fraction $\mathrm{Z}$. The following equation defines the mixture fraction (McGrattan et al., 2007):

$$
Z=\frac{s Y_{F}-\left(Y_{O}-Y_{O}^{\infty}\right)}{s Y_{F}^{I}+Y_{O}^{\infty}} \quad ; \quad s=\frac{v_{O} M_{O}}{v_{F} M_{F}}
$$

Where,

$Y_{f}=$ Mass fraction of fuel, $\mathrm{g} / \mathrm{g}$

$Y_{o}=$ Mass fraction of oxygen, $\mathrm{g} / \mathrm{g}$

$Y_{O}^{\infty}=$ Mass fraction of ambient oxygen, $\mathrm{g} / \mathrm{g}$

$Y_{F}^{I}=$ Mass fraction of fuel in the fuel stream, $\mathrm{g} / \mathrm{g}$

$M_{O}=$ Oxygen molecular weight, $\mathrm{g} / \mathrm{mol}$

$M_{F}=$ Fuel molecular weight, $\mathrm{g} / \mathrm{mol}$ 
$v_{o}=$ Oxygen stoichiometric coefficient

$v_{F}=$ Fuel stoichiometric coefficient

The conservation law is satisfied by the mixture fraction Z (McGrattan et al., 2010):

$$
\frac{\partial \rho Z}{\partial t}+\nabla \cdot \rho \boldsymbol{u} Z=\nabla \cdot \rho D \nabla Z
$$

$D=$ Material diffusivity, $\mathrm{m}^{2} / \mathrm{s}$

Eq. 4-5 represents the fuel and oxygen mass conservation equation by a linear combination. The chemical reaction that consumes fuel and oxygen is assumed to occur rapidly so that fuel and oxygen cannot exist at the same time in a control volume.

\subsection{Numerical Method for Determining Interface Height:}

There are different methods that can be used to estimate the interface location between the hot, smoke-laden layer and the cool lower layer in a burning compartment. In two zone models the interface height is well defined, in reality, however, and also in the predictions of CFD models, there are no two distinct zones, therefore some methods have been developed to estimate the average zone temperature and interface height. Janssens and Tran (1992) proposed a method in which the interface height $z_{\text {int }}$ is computed based on $\mathrm{T}(\mathrm{z})$, which defines the temperature as a function of height:

$$
\begin{aligned}
& \left(H-z_{\text {int }}\right) T_{u}+z_{\text {int }} T_{l}=\int_{0}^{H} T(z) d_{z}=I_{1} \\
& \left(H-z_{\text {int }}\right) \frac{1}{T_{u}}+z_{\text {int }} \frac{1}{T_{l}}=\int_{0}^{H} \frac{1}{T(z)} d_{z}=I_{2}
\end{aligned}
$$




$$
Z_{\text {int }}=\frac{T_{l}\left(I_{1} I_{2}-H^{2}\right)}{I_{1}+I_{2} T_{l}^{2}-2 T_{l} H}
$$

Where:

$z_{\text {int }}=$ interface height, $\mathrm{m}$

$T_{u}=$ Upper layer temperature, ${ }^{\circ} \mathrm{C}$

$T_{l}=$ Lower layer temperature, ${ }^{\circ} \mathrm{C}$

$z$ = Height, $\mathrm{m}$

By using numerical integration for $I_{1}$ and $I_{2}$ and assuming $T_{1}$ is the lowest mesh temperature in a CFD model, the average upper layer temperature is defined using:

$$
\mathrm{T}_{\mathrm{u}}=\frac{\int_{\mathrm{z}_{\text {int }}}^{\mathrm{H}} \mathrm{T}(\mathrm{z}) d z}{\left(\mathrm{H}-\mathrm{z}_{\text {int }}\right)}
$$

\subsection{Boundary Conditions}

The boundary conditions which have been used in the simulation are as follows:

- Solid wall: The atrium walls have been modeled as solid concrete walls with $200 \mathrm{~mm}$ thickness.

- Wall opening: The make-up air openings on the wall have been assumed to be passive openings.

- Floor: The floor of the atrium has been modeled as $200 \mathrm{~mm}$ thick concrete.

- Ceiling vent: A constant volumetric flow rate has been defined throughout the ceiling area based on the volumetric flow rate required to maintain the interface height at specific level. 


\subsection{Computational Grid}

Several preliminarily runs were conducted in order to determine the optimum grid size, which would yield acceptable results. The Carleton University atrium was considered for these simulations. The preliminary runs simulated the test in the atrium with a 1MW heat release rate and $1 \mathrm{~m} / \mathrm{s}$ make-up air velocity. Three different grid sizes of 0.13 $\mathrm{m} \times 0.13 \mathrm{~m} \times 0.13 \mathrm{~m} ; 0.26 \mathrm{~m} \times 0.26 \mathrm{~m} \times 0.26 \mathrm{~m}$; and $0.52 \mathrm{~m} \times 0.52 \mathrm{~m} \times 0.52 \mathrm{~m}$ were employed for the entire space of the atrium. The simulations were performed using a computer with eight core $i 7$ processors. In order to get the best performance of the computer system, parallel processing is used by equally dividing the computational domain by eight meshes along the height of the atrium. Figures 4-1 to 4-3 show the computational domain with the different mesh sizes.

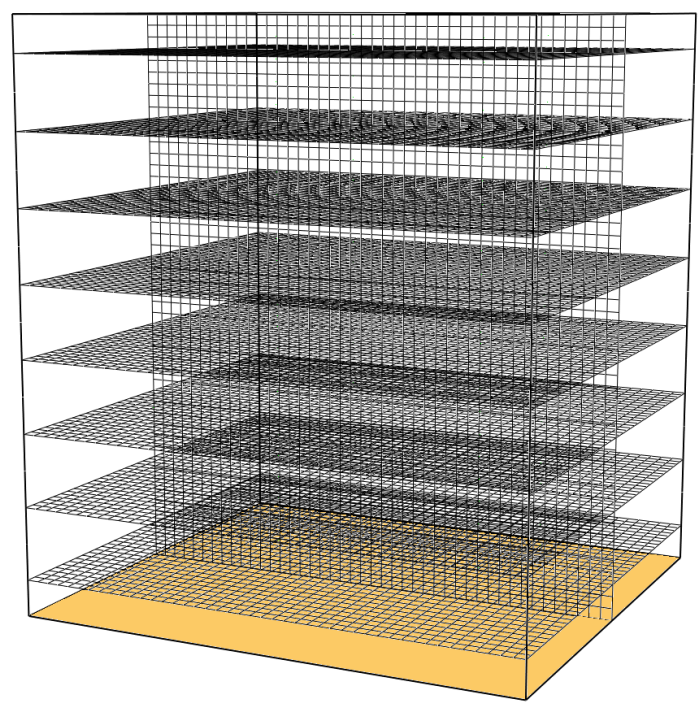

Figure 4-1 0.52 m x 0.52 m x $0.52 \mathrm{~m}$ (coarse grid) 


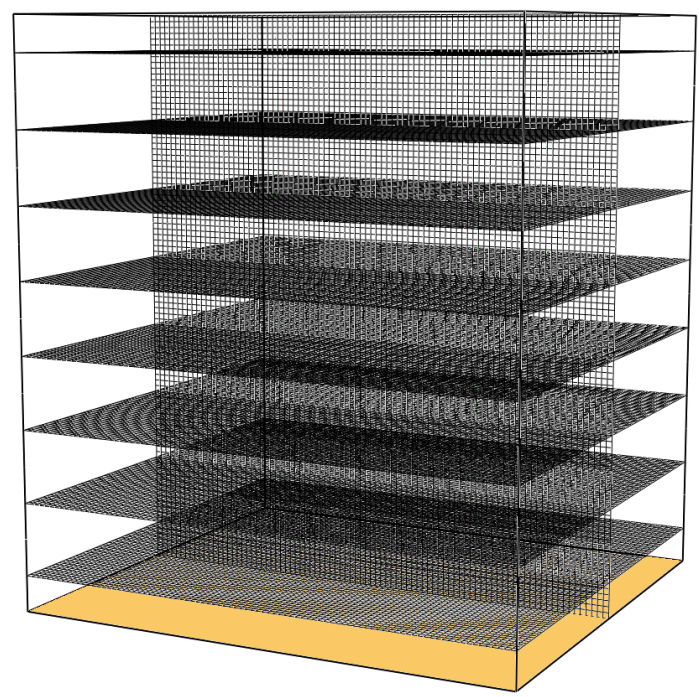

Figure 4-2 $0.26 \mathrm{~m}$ x $0.26 \mathrm{~m}$ x $0.26 \mathrm{~m}$ (medium grid)

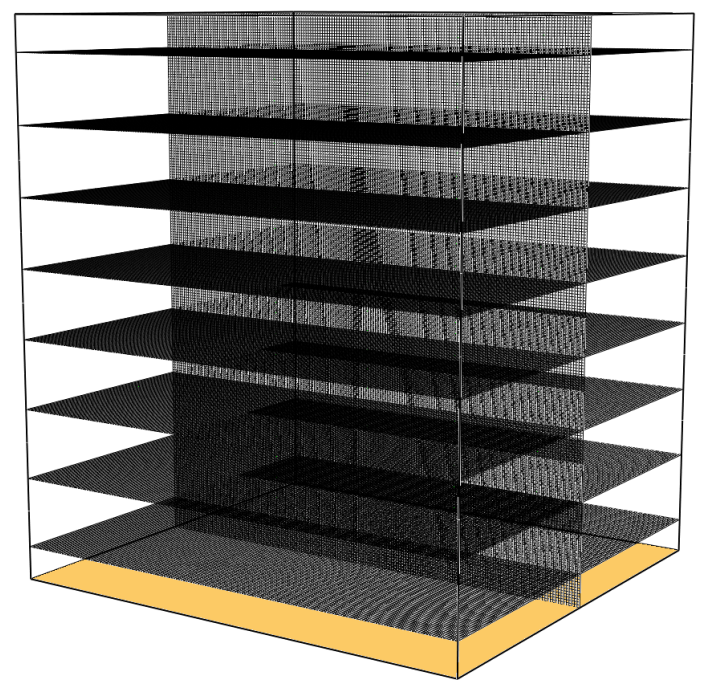

Figure 4-3 0.13 m x 0.13 m x 0.13 m (fine grid)

The Layer Height feature of FDS was used to determine the smoke layer height in the atrium. This feature uses the Janssens and Tran (1992) method. Table 4-1 shows the simulation results for the smoke layer height for the three different computational grid sizes. 
Table 4-1 Effect of computational grid size on the simulation results

\begin{tabular}{|c|c|c|c|c|c|}
\hline $\begin{array}{l}\text { Fire } \\
\text { Size } \\
(\mathrm{MW})\end{array}$ & $\begin{array}{l}\text { Make-up } \\
\text { air } \\
\text { velocity } \\
(\mathrm{m} / \mathrm{s})\end{array}$ & $\begin{array}{l}\text { Opening } \\
\text { arrangeme } \\
\text { nt }\end{array}$ & Grid size & $\begin{array}{l}\text { Smoke layer } \\
\text { height } \\
\text { (m) }\end{array}$ & $\begin{array}{l}\text { Simulation } \\
\text { time } \\
\text { (hour) }\end{array}$ \\
\hline \multirow{3}{*}{1} & \multirow{3}{*}{1} & \multirow{3}{*}{1 side } & $\begin{array}{l}0.13 \times 0.13 \times 0.13 \\
\text { (Fine) }\end{array}$ & 8.92 & 47 \\
\hline & & & $\begin{array}{l}0.26 \times 0.26 \times 0.26 \\
\text { (Medium) }\end{array}$ & 8.96 & 14 \\
\hline & & & $\begin{array}{l}0.52 \times 0.52 \times 0.52 \\
\text { (Coarse) }\end{array}$ & 9.51 & 6 \\
\hline
\end{tabular}

It can be seen from Table 4- 1 that the $0.26 \mathrm{~m} \times 0.26 \mathrm{~m} \times 0.26 \mathrm{~m}$ grid size is the optimal grid size, as the results are very close to the results of the $0.13 \mathrm{~m} \times 0.13 \mathrm{~m} \times 0.13 \mathrm{~m}$ grid size, but with a shorter simulation time. Although the $0.52 \mathrm{~m} \times 0.52 \mathrm{~m} \times 0.52 \mathrm{~m}$ grid had the shortest running time, the results of the smoke layer height are about $7 \%$ different from the results of the fine and medium grid sizes. The selected grid size is similar to the grid sizes used in Zhou's research (2006).

\subsection{Simulation Plan}

The experimental data were used for comparison with the numerical predictions. Therefore model geometry, ambient conditions and exhaust rates were matched with the experimental conditions. Simulations were conducted with the same conditions as the experiments in order to compare with experimental data and correlation predictions. The simulation plan was the same as the experimental plan, which investigated the effect of make-up air velocity, opening arrangement and air jet direction on the smoke condition in atrium fires. 


\section{Chapter 5: Effects of Make-up Air Velocity on Atrium Smoke}

\section{Conditions}

\subsection{Introduction}

This chapter presents the results of full-scale experiments and CFD modelling of fire in an atrium equipped with a smoke exhaust system. The tests considered the effects of different make-up air velocities on the conditions in the atrium for three fire tests. The fire tests have been simulated with FDS in order to compare the predictions with fullscale test results. Atrium correlations have also been employed to estimate the smoke conditions in the atrium, including the hot layer temperature and the interface height. The N-Percentage method (Cooper et al., 1982) has been used to determine the smoke layer interface height from the experimental temperature profiles along the atrium height. Make-up air velocities of $1,1.5$ and $2 \mathrm{~m} / \mathrm{s}$ have been considered and their impact on the conditions in the atrium is discussed in this chapter. A $2 \mathrm{~m} / \mathrm{s}$ make-up air velocity was the maximum that could be obtained in the test facility.

Carleton University's full-scale atrium facility has been used to investigate the effectiveness of atrium smoke management systems. Several full-scale fire tests have been conducted in this facility to investigate the impact of make-up air velocity on the smoke layer interface height and plume characteristics. The experiments have also been modeled using FDS 5.0 (McGrattan et al., 2010) and the model predictions are compared with the experimental results. Correlations have also been employed to calculate the smoke conditions in the atrium, including hot layer temperature and interface height. 
The opening being investigated is located in close proximity to the fire, so that the velocity impacting the plume would be nearly equal to the velocity at the opening. The specific configuration involves locating the opening near the fire and locating the fire far from the walls. Therefore an arrangement of ductwork has been used. While this does not reflect real world conditions, it represents a worst case. Real world conditions are expected to be better because either the fire is close to an opening in the wall, but there is less entrainment when the plume contacts the wall, or the fire is far from the opening, so the make-up air has less impact on the plume than if it is closer to the fire.

\subsection{Atrium Geometry and Instrumentation}

To provide visual observations of the development of the smoke layer, a $25-\mathrm{m}$ long measuring tape has been installed in the atrium from the floor to the ceiling and three video cameras have been employed to record smoke movement during tests. For measuring the atrium temperatures four thermocouple trees with 25 thermocouples each along the height of the atrium have been installed. Figures 5-1 to 5-3 illustrate the geometry of the atrium and location of the thermocouple trees used for these tests. All thermocouples have been protected to minimize the effect of radiation from the flames.

Propane burners located one meter above the floor in the middle of the atrium have been used for the fire. The propane mass flow rate was adjusted to provide the required heat release rate of the fire. The heat release rate was calculated by multiplying the measured mass flow rate by the heat of combustion of propane. National Instruments data acquisition system and LabVIEW (National Instruments, 2012) have been used to record the data during tests. 


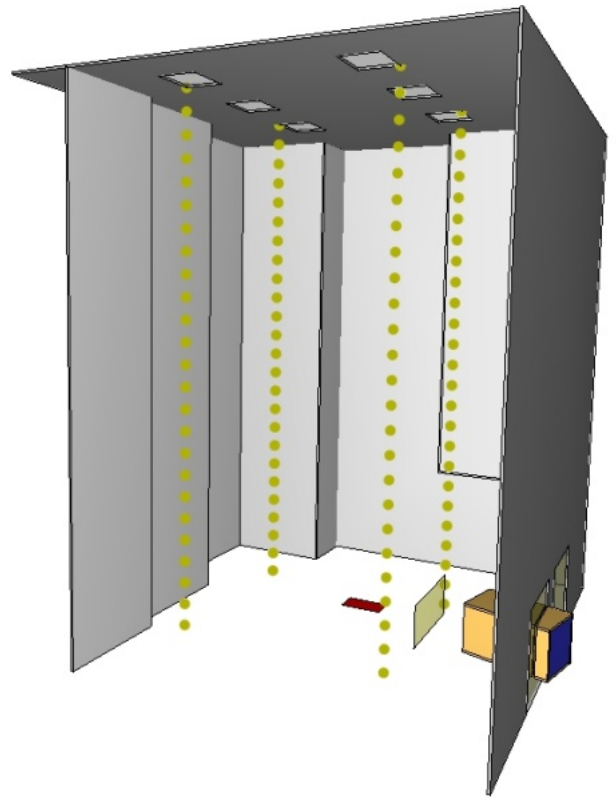

Figure 5-1 3D schematic diagram of the atrium

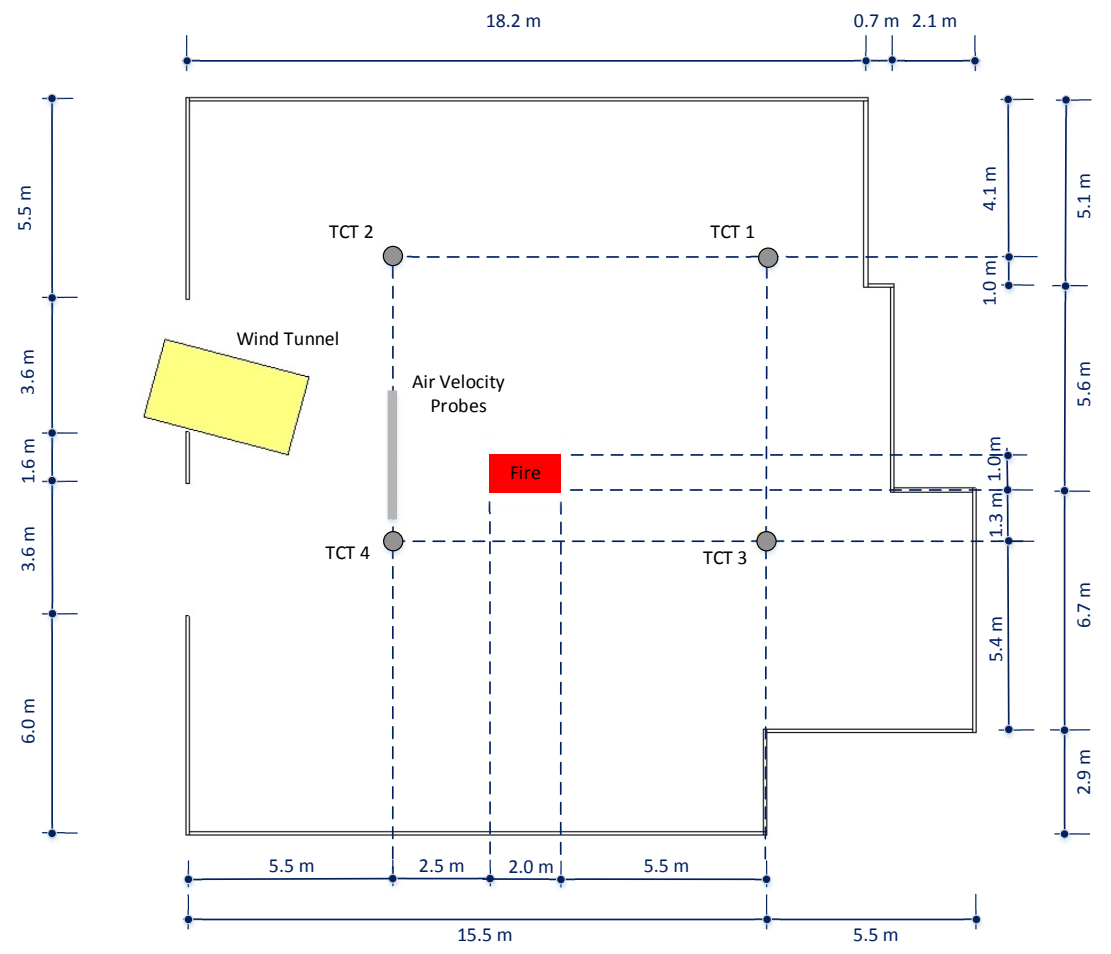

Figure 5-2 Location of thermocouple trees 


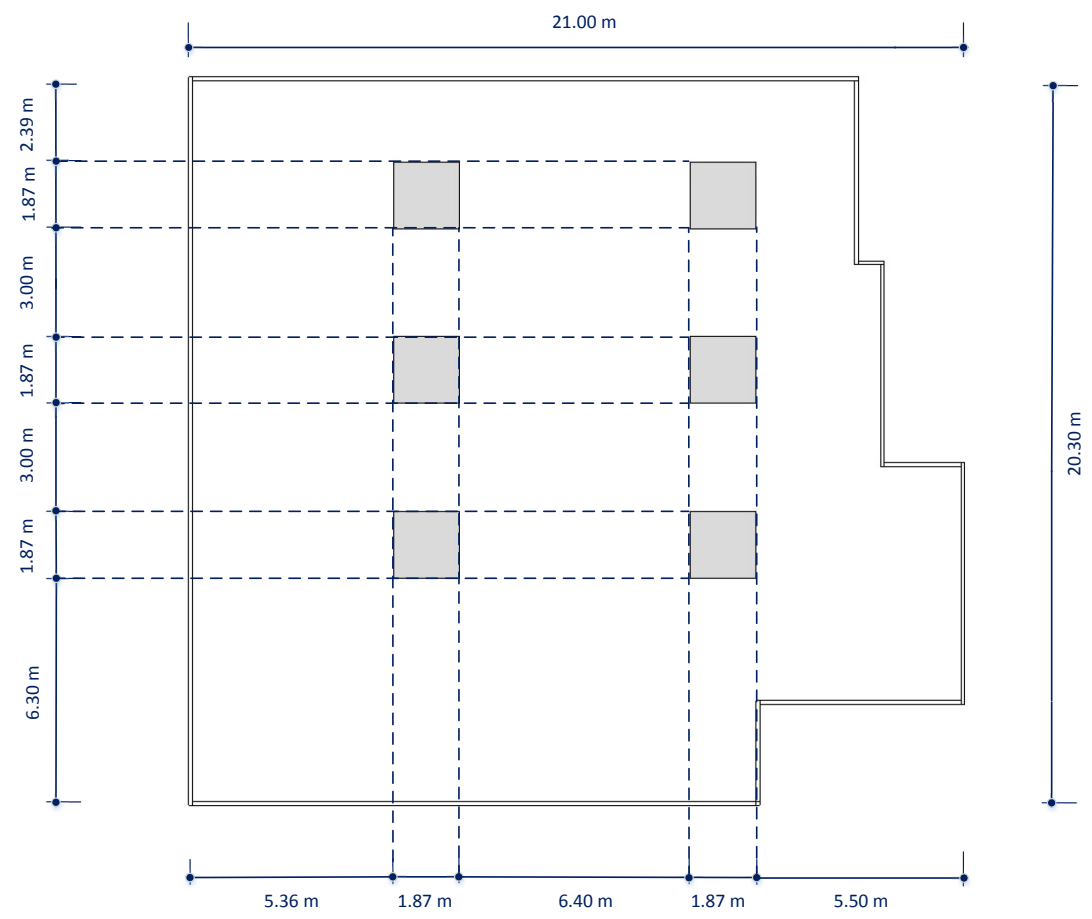

Figure 5-3 Ceiling geometry

A wind tunnel with the size of $2 \mathrm{~m} \times 2 \mathrm{~m}$ and $4 \mathrm{~m}$ length was constructed $1 \mathrm{~m}$ above the floor and used to generate an air flow of different velocities directed to the fire. The duct was place at a distance of $5 \mathrm{~m}$ from the burners. Four bi-directional velocity probes have been installed halfway between the duct and the burner to measure the static and dynamic pressure in order to obtain the air velocity using Bernoulli's equation, Eq. 5-1. The wind tunnel and bi-directional probes are shown in Figure 5-4.

$$
P_{1}-P_{2}=\frac{1}{2} \rho_{a}\left(V_{2}^{2}-V_{1}^{2}\right)
$$


Where:

$\mathrm{P}_{1}=$ Air pressure before the probe, $\mathrm{Pa}$

$\mathrm{P}_{2}=$ Air pressure after the probe, $\mathrm{Pa}$

$\mathrm{V}_{1}=$ Air velocity before the probe, $\mathrm{m} / \mathrm{s}$

$\mathrm{V}_{2}=$ Air velocity after the probe, $\mathrm{m} / \mathrm{s}$

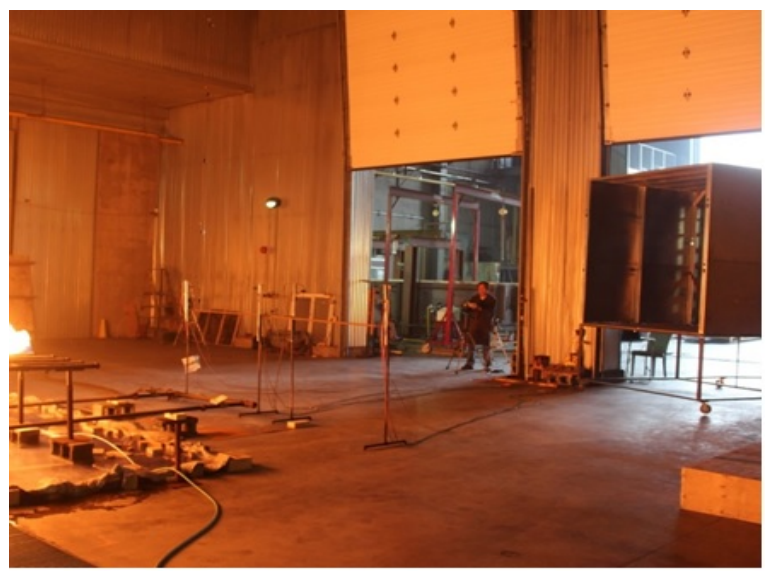

Figure 5-4 Wind tunnel and make-up air velocity measuring system

\subsection{Full-Scale Tests}

Nine full-scale fire tests have been performed to investigate the effect of $1,1.5$ and 2 $\mathrm{m} / \mathrm{s}$ make-up air velocity on the conditions in the atrium for 1,2 and $5 \mathrm{MW}$ fire heat release rates. Similar fire sizes were also used for the atrium studies described in Zhou (2006) and Kerber and Milke (2007). For each test the atrium conditions were allowed to reach steady state and remain at steady state for a short period of time. Following that, the make-up air velocity was increased as required by the next test and waited until steady state again. The fire test characteristics and the smoke layer heights obtained from the correlations are shown in Table 5-1. 
Table 5-1 Fire tests and designed smoke layer height

\begin{tabular}{|c|c|c|c|c|c|c|}
\hline $\begin{array}{l}\text { Fire } \\
\text { Test }\end{array}$ & $\begin{array}{c}\text { Make-Up } \\
\text { Air Velocity } \\
(\mathrm{m} / \mathrm{s})\end{array}$ & $\begin{array}{c}\text { Ambient } \\
\text { Temperature } \\
\left({ }^{\circ} \mathrm{C}\right)\end{array}$ & $\begin{array}{c}\text { Exhaust } \\
\text { Rate } \\
\left(\mathrm{m}^{3} / \mathrm{s}\right)\end{array}$ & $\begin{array}{c}\text { Opening } \\
\text { Area } \\
\left(\mathrm{m}^{2}\right)\end{array}$ & $\begin{array}{l}\text { Duration } \\
\text { (Sec) }\end{array}$ & $\begin{array}{l}\text { Smoke Layer Height } \\
\text { from Correlation } \\
(\mathrm{m})\end{array}$ \\
\hline \multirow{3}{*}{$1 \mathrm{MW}$} & 1 & -1 & 33 & 32.06 & $600-1050$ & 12.93 \\
\hline & 1.5 & -1 & 33 & 32.06 & $1150-1550$ & 12.93 \\
\hline & 2 & -1 & 33 & 32.06 & $1650-2100$ & 12.93 \\
\hline \multirow{3}{*}{$2 \mathrm{MW}$} & 1 & -1 & 33 & 32.06 & $1300-2050$ & 11.2 \\
\hline & 1.5 & -1 & 33 & 32.06 & $2150-2850$ & 11.2 \\
\hline & 2 & -1 & 33 & 32.06 & $2950-3700$ & 11.2 \\
\hline \multirow{3}{*}{$5 \mathrm{MW}$} & 1 & 3.5 & 33 & 32.06 & $800-1250$ & 9 \\
\hline & 1.5 & 3.5 & 33 & 32.06 & $1350-1750$ & 9 \\
\hline & 2 & 3.5 & 33 & 32.06 & $1850-2300$ & 9 \\
\hline
\end{tabular}




\subsubsection{MW Fire Test:}

At the beginning of the test, the smoke management system was turned on and allowed to work for $10 \mathrm{~min}$ before starting the fire. The conditions in the atrium reached steady state at $600 \mathrm{sec}$ for the $1 \mathrm{~m} / \mathrm{s}$ fresh air velocity and the test continued for another 450 sec. The make-up air velocity was raised to $1.5 \mathrm{~m} / \mathrm{s}$ and conditions became steady at $1150 \mathrm{sec}$. After $400 \mathrm{sec}$ the make-up air velocity was raised to $2 \mathrm{~m} / \mathrm{s}$ and steady conditions occurred at $1650 \mathrm{sec}$. Figure 5-5 shows the variation of average temperature of all four thermocouple trees during the steady state condition and Figure 5-6 illustrates the average temperature over the $200 \mathrm{sec}$ of each steady condition versus atrium height in the $1 \mathrm{MW}$ fire test exposed to different fresh air velocities. As Figure 5-6 shows the increase of the velocity causes a decrease of the hot layer height and also an increase of the hot layer temperature. The increase of the temperature however may not be due to the increased velocity, but due to the fact that the higher velocity tests followed the lower velocity tests. This causes an increase of the temperature in the atrium from bottom to the top. 


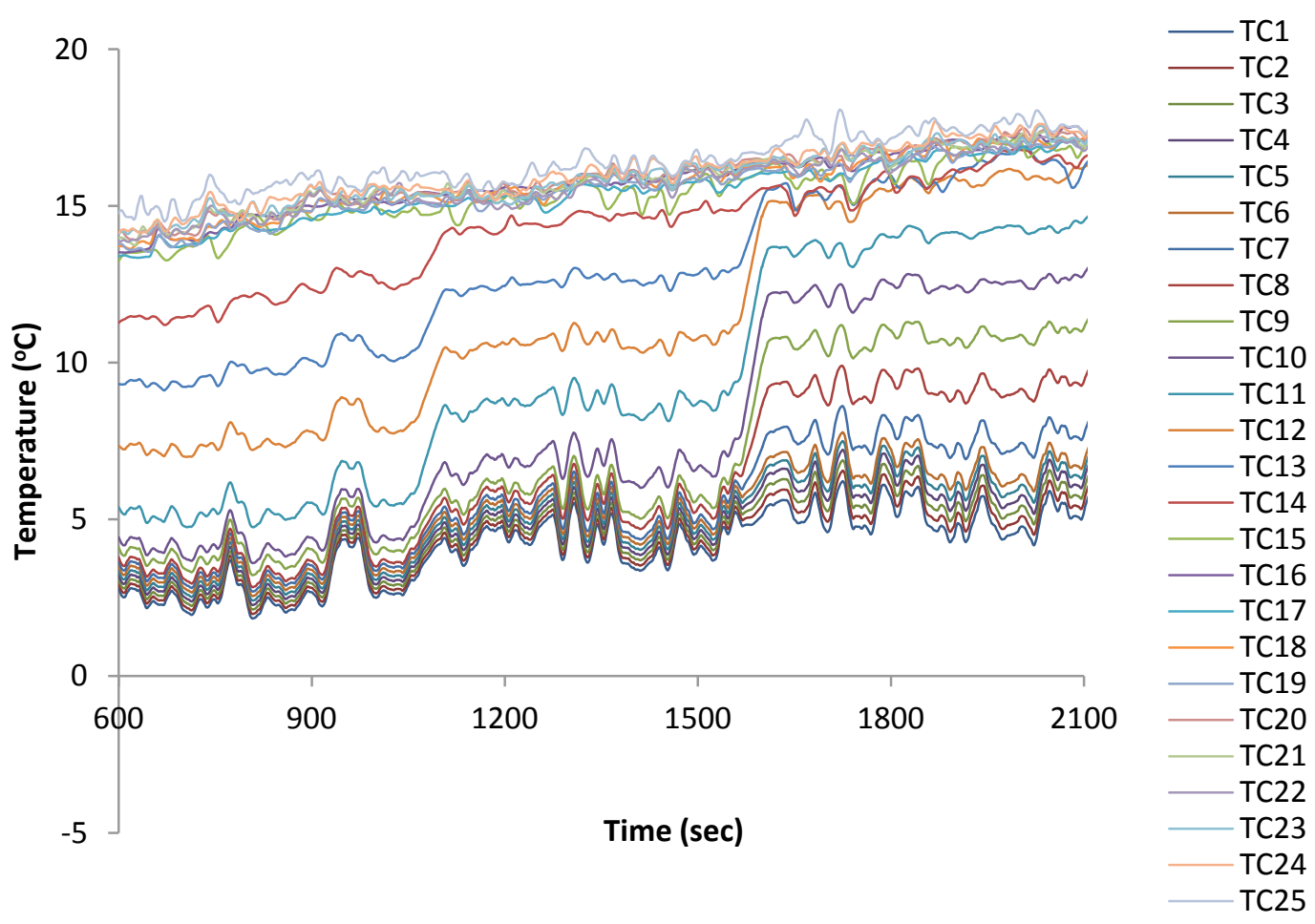

Figure 5-5 Temperature variation for the 1 MW fire test

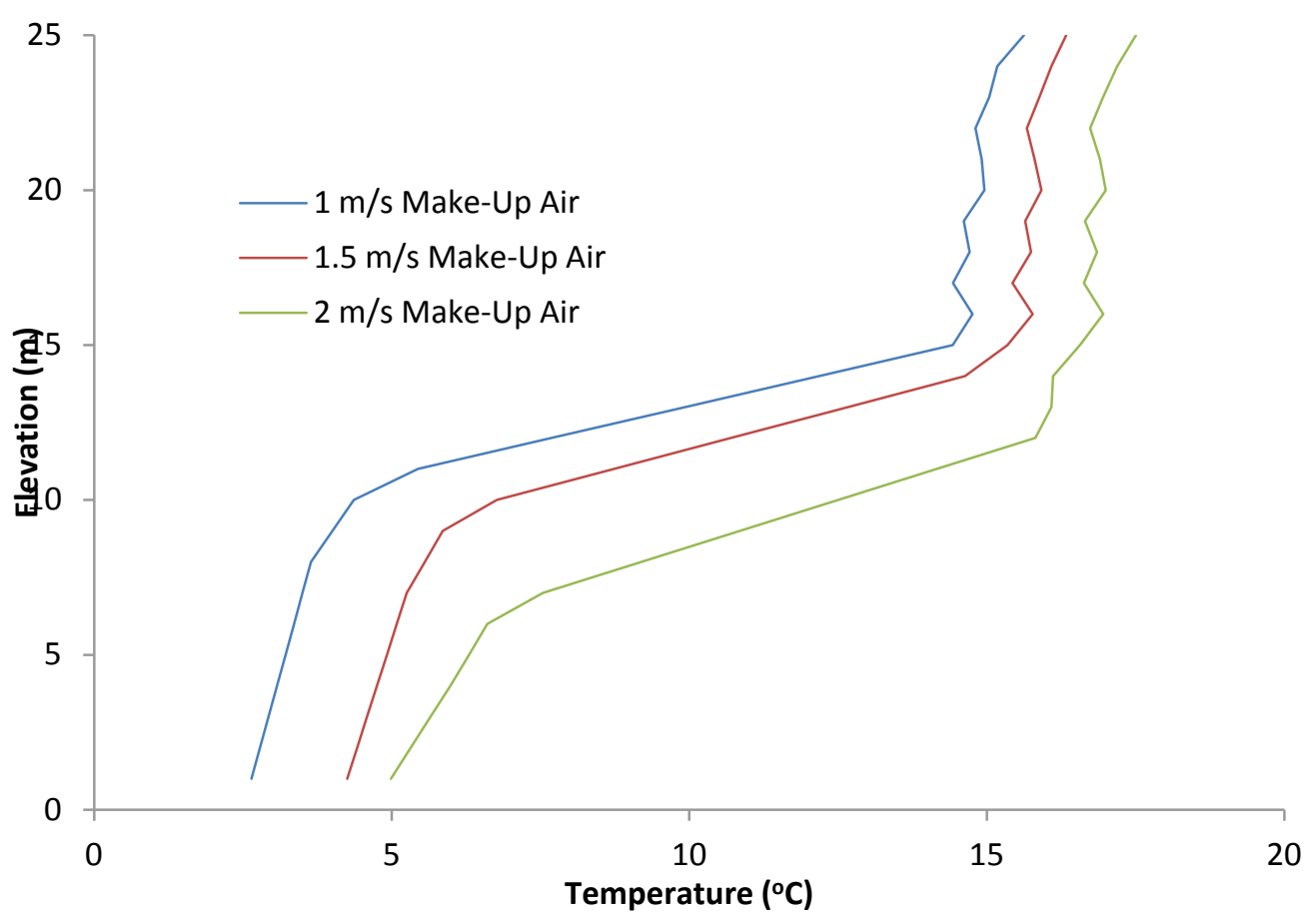

Figure 5-6 Vertical temperature profiles for the $1 \mathrm{MW}$ fire test 
The first indication of hot layer temperature and smoke layer depth has been calculated based on the N-Percentage method with $\mathrm{N}=0.2$. Figure 5-7 shows the average hot layer temperature, cold layer temperature and the first indication of hot layer temperature during the steady state condition.

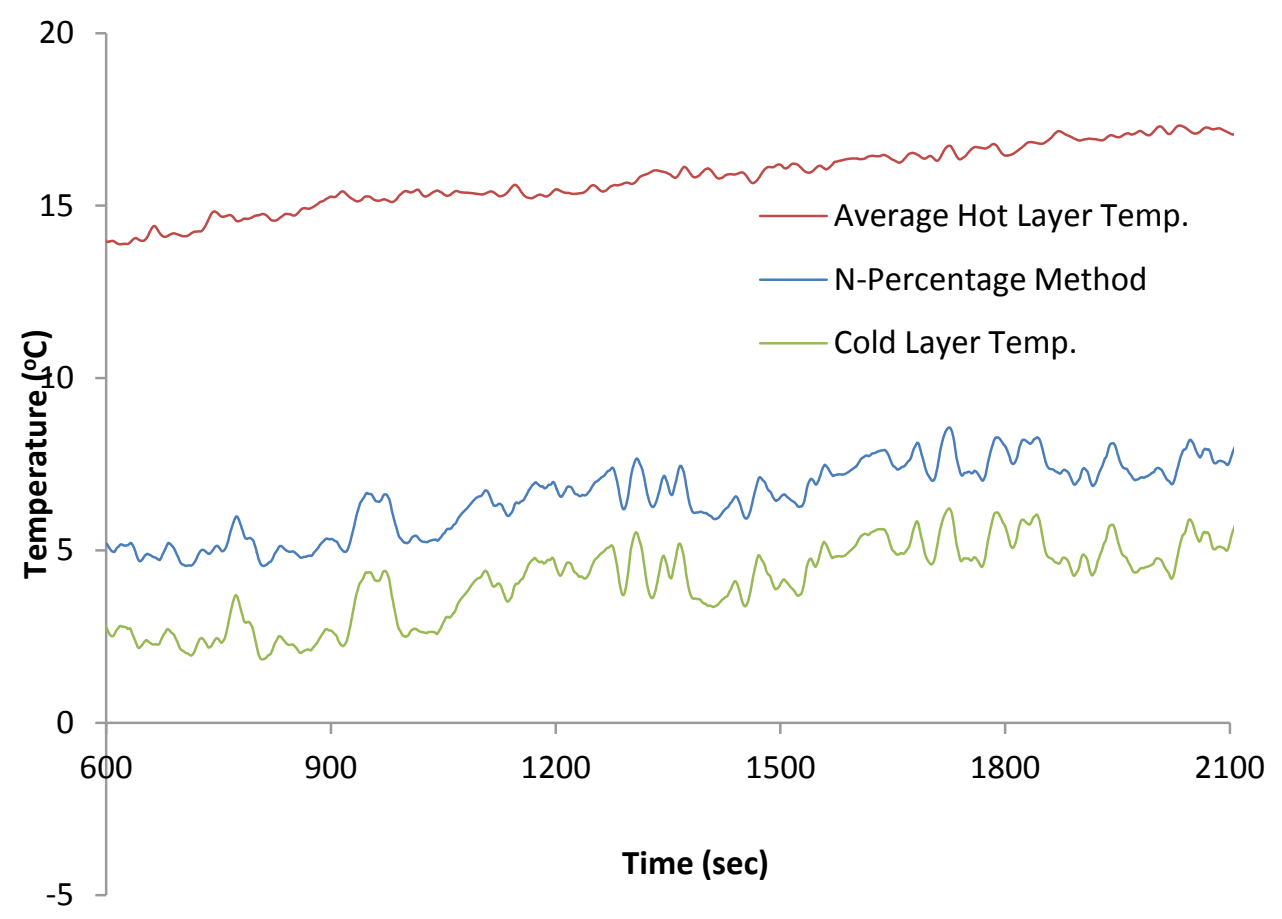

Figure 5-7 Hot layer, cold layer and interface temperature for the $1 \mathrm{MW}$ fire test

Table 5-2 shows the average smoke layer height during the $200 \mathrm{sec}$ of each steady state condition at different points of the atrium. The mean deviation may represent the turbulence at the smoke layer height. As shown in the table, the mean deviation increases more when the make-up air velocity increases from 1.5 to $2.0 \mathrm{~m} / \mathrm{s}$ than from 1.0 to $1.5 \mathrm{~m} / \mathrm{s}$. The location of points is the atrium is same as the thermocouple tree locations. 
Table 5-2 Smoke layer height at different points in 1 MW fire tests

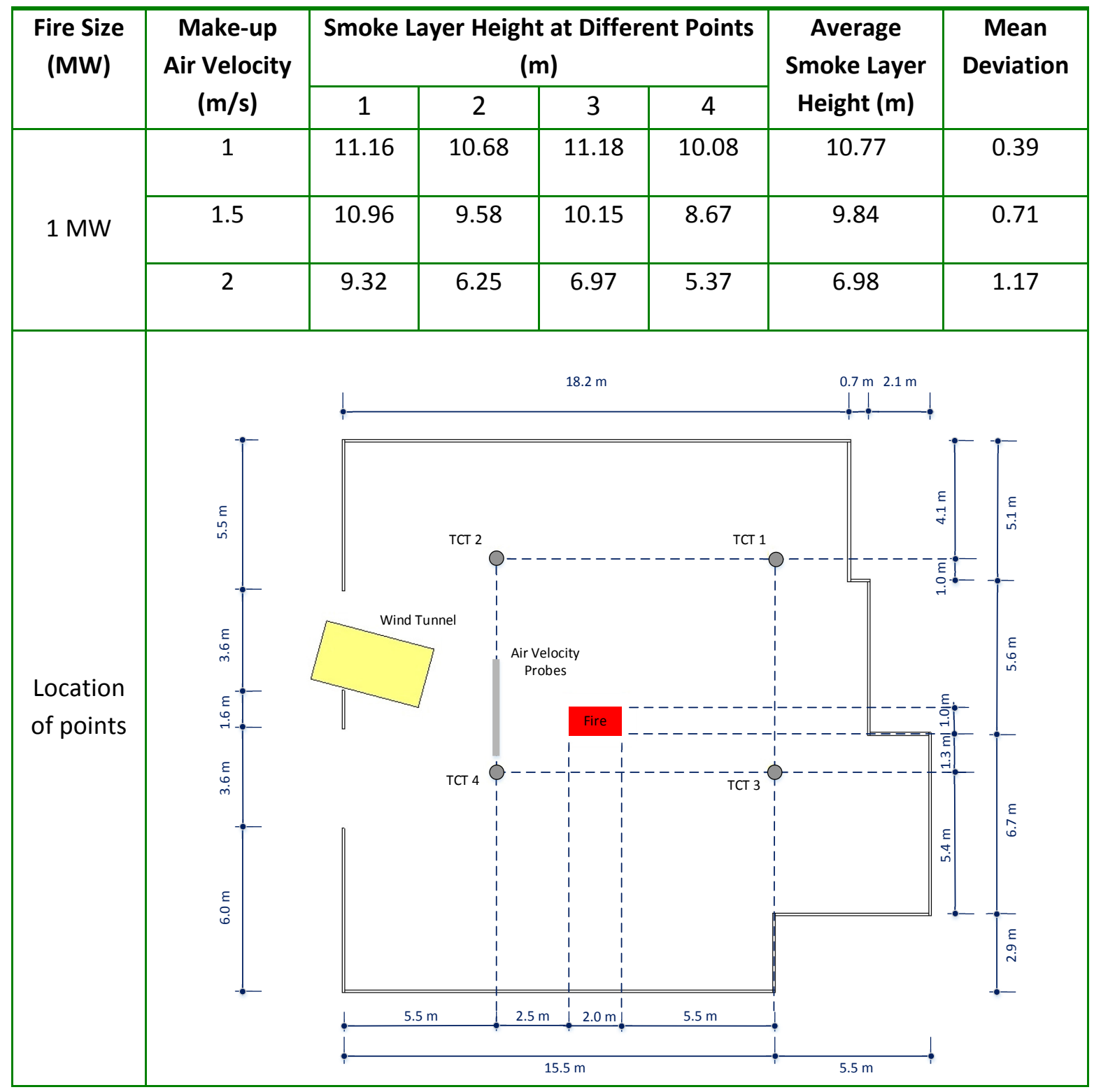




\subsubsection{MW Fire Test}

The $2 \mathrm{MW}$ fire test continued after the $1 \mathrm{MW}$ fire test. The smoke level reached steady conditions after $1300 \mathrm{sec}$ for the $1 \mathrm{~m} / \mathrm{s}$ make-up air velocity. The velocity was increased to $1.5 \mathrm{~m} / \mathrm{s}$ at $2050 \mathrm{sec}$ and steady smoke layer conditions occurred at $2150 \mathrm{sec}$. The velocity was then raised to $2 \mathrm{~m} / \mathrm{s}$ at $2850 \mathrm{sec}$ and steady conditions were achieved at $2950 \mathrm{sec}$. The test was terminated at $3700 \mathrm{sec}$. Figure 5-8 illustrates the average temperature recorded by all four thermocouple trees during the steady state conditions and the vertical temperature profile over the $200 \mathrm{sec}$ of each steady condition along the atrium height is shown in Figure 5-9.

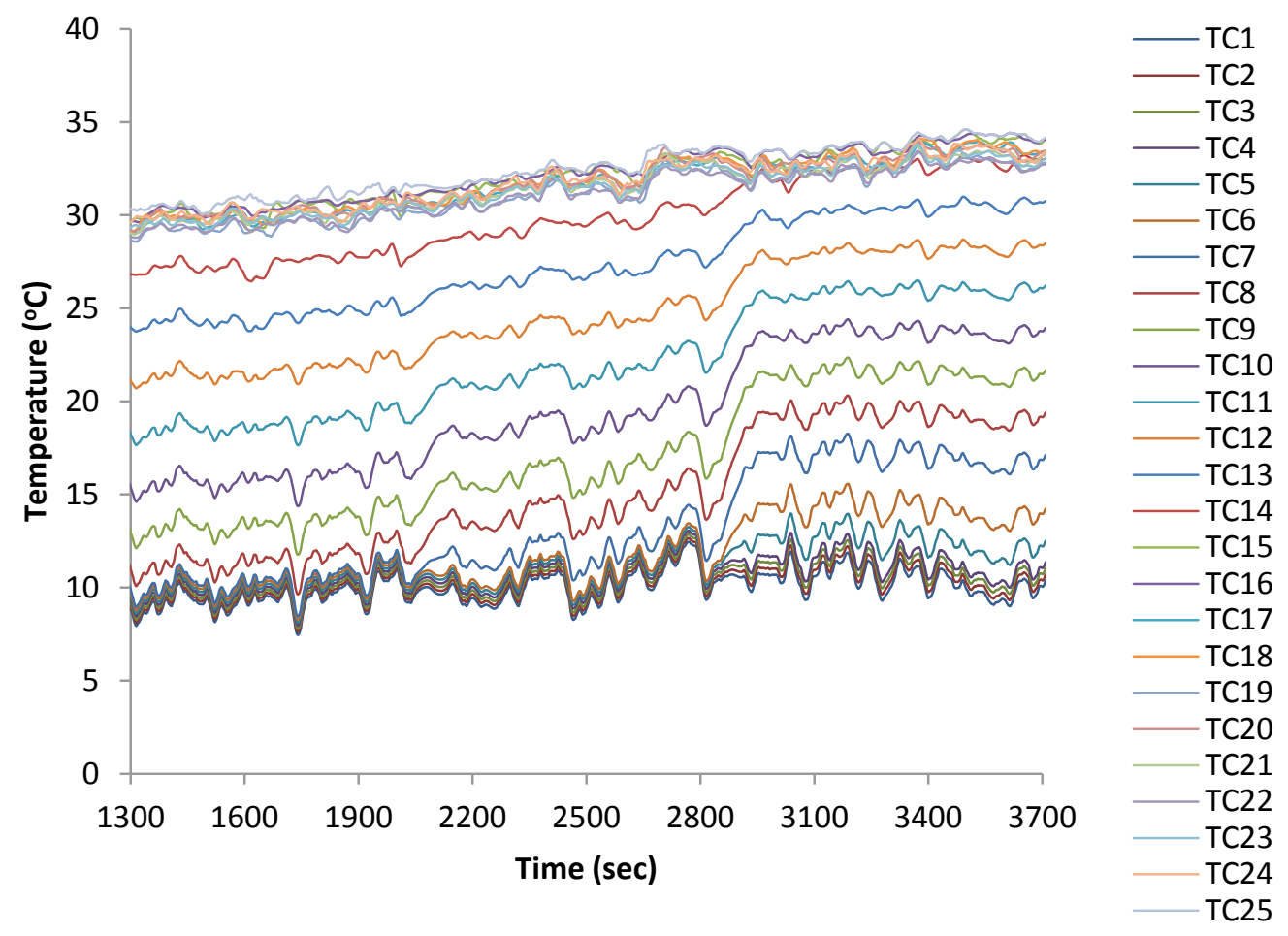

Figure 5-8 Temperature variation for the 2 MW fire test 


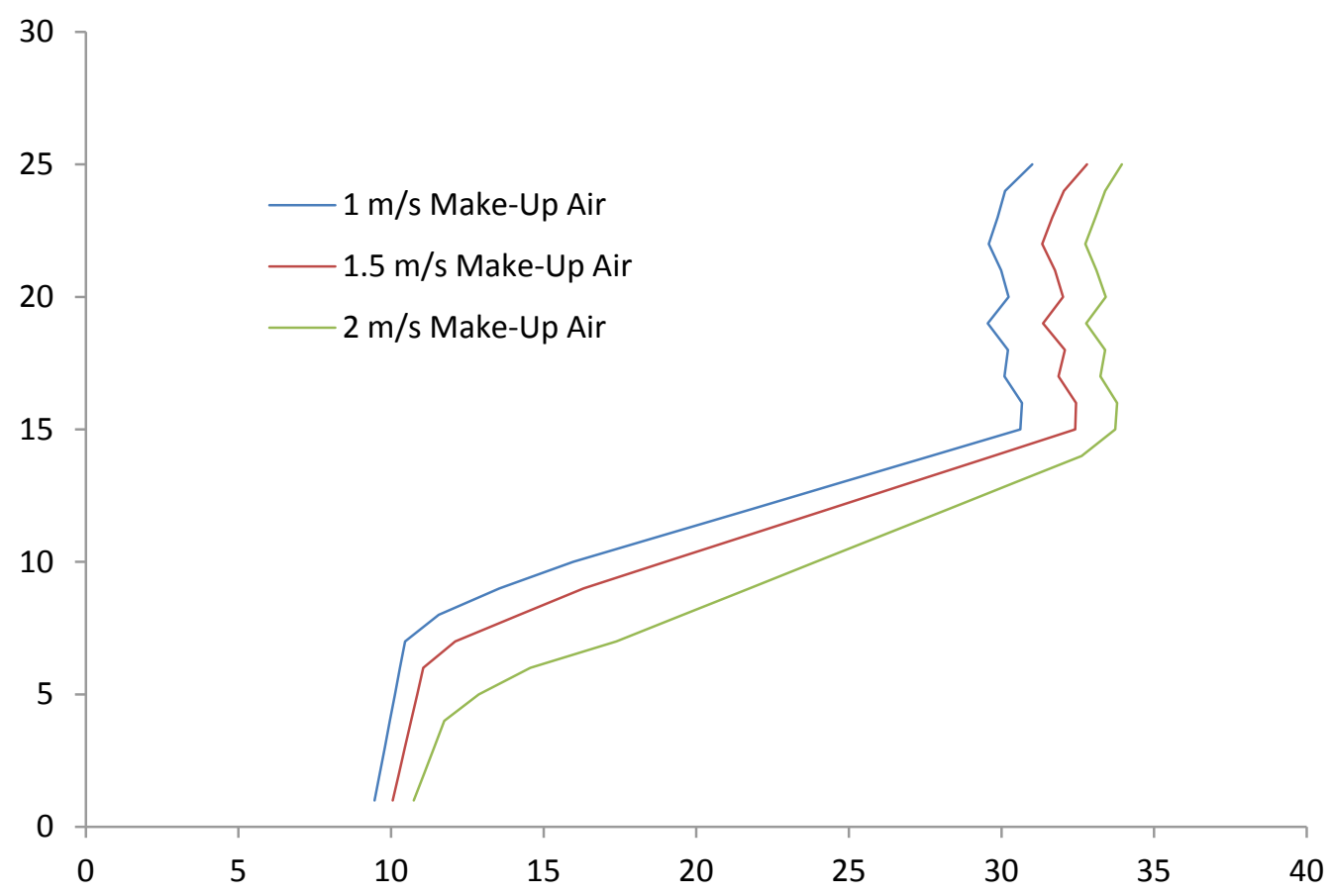

Figure 5-9 Vertical temperature profiles for the $2 \mathrm{MW}$ fire test

The average hot layer temperature increased from $15^{\circ} \mathrm{C}$ to almost $31^{\circ} \mathrm{C}$ when the fire was increased to $2 \mathrm{MW}$. The average hot layer temperature, cold layer temperature and the first indication of smoke layer temperature are illustrated in Figure 5-10. 


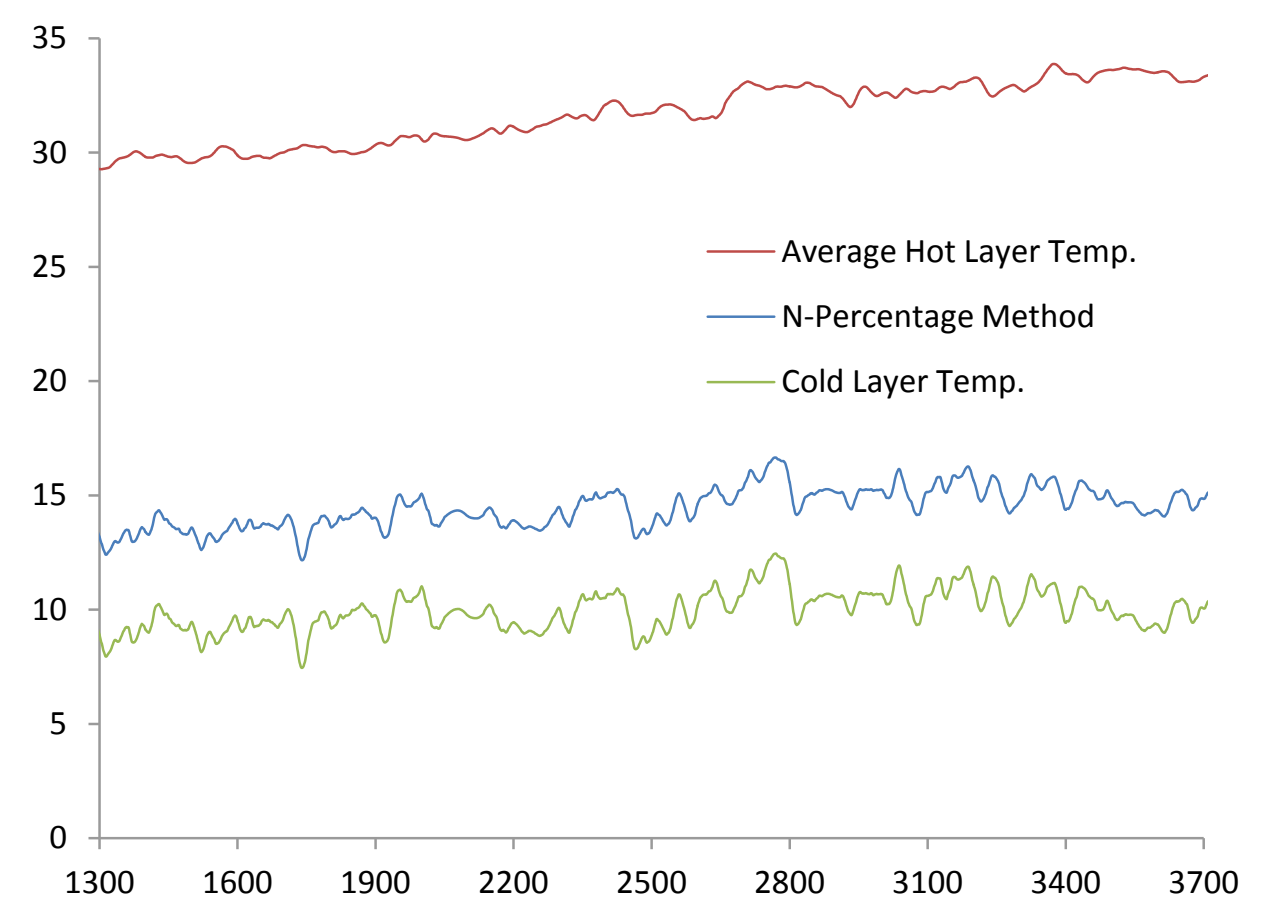

Figure 5-10 Hot layer, cold layer and interface temperature for the $2 \mathrm{MW}$ fire test

The smoke layer temperatures at different points in the atrium are shown in Table 5-3. The average smoke layer of all four points shows that the effect of increasing the makeup air velocity from 1.5 to $2 \mathrm{~m} / \mathrm{s}$ on smoke layer height is more than when rising from 1 to $1.5 \mathrm{~m} / \mathrm{s}$. In addition, the mean deviation shows that the disturbance in smoke layer increases considerably with increasing the make-up air velocity to $2 \mathrm{~m} / \mathrm{s}$. 
Table 5-3 Smoke layer height at different points in 2 MW fire tests

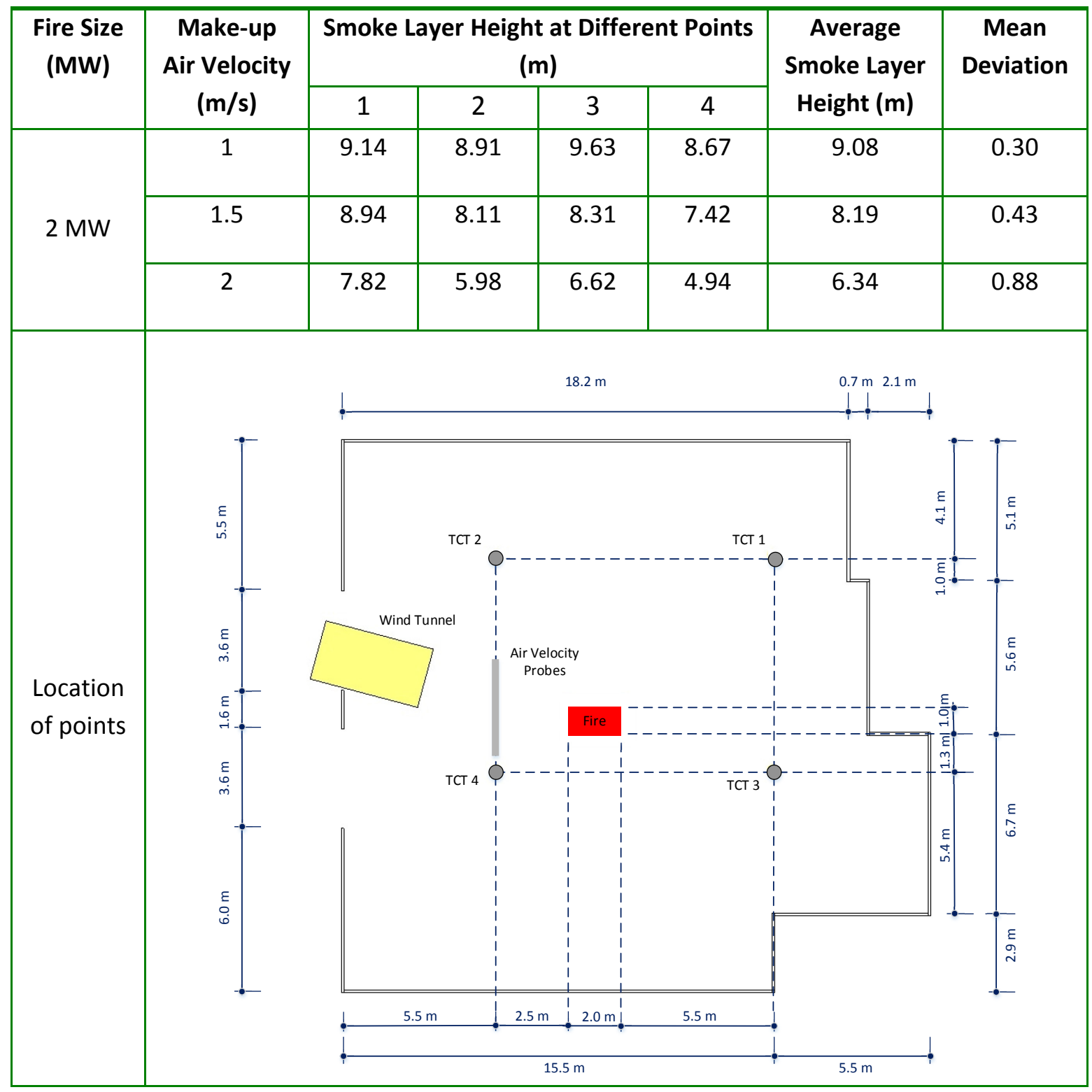




\subsubsection{MW Fire Test}

The $5 \mathrm{MW}$ fire test started 10 minutes after the exhaust system was turned-on. Steady conditions for the $1 \mathrm{~m} / \mathrm{s}$ air velocity started at $800 \mathrm{sec}$. The air velocity was increased to $1.5 \mathrm{~m} / \mathrm{s}$ at $1250 \mathrm{sec}$ and reached steady conditions at $1350 \mathrm{sec}$, then it was raised to 2 $\mathrm{m} / \mathrm{s}$ at $1750 \mathrm{sec}$ and steady conditions were achieved at $1850 \mathrm{sec}$. The $5 \mathrm{MW}$ fire test ended at $2300 \mathrm{sec}$. Figure 5-11 shows the average temperature variation of all four thermocouple trees during the steady state condition in the atrium and Figure 5-12 illustrates the average temperature over the $200 \mathrm{sec}$ of each test versus atrium height when the smoke layer was in steady conditions for the $1,1.5$ and $2 \mathrm{~m} / \mathrm{s}$ air velocities.

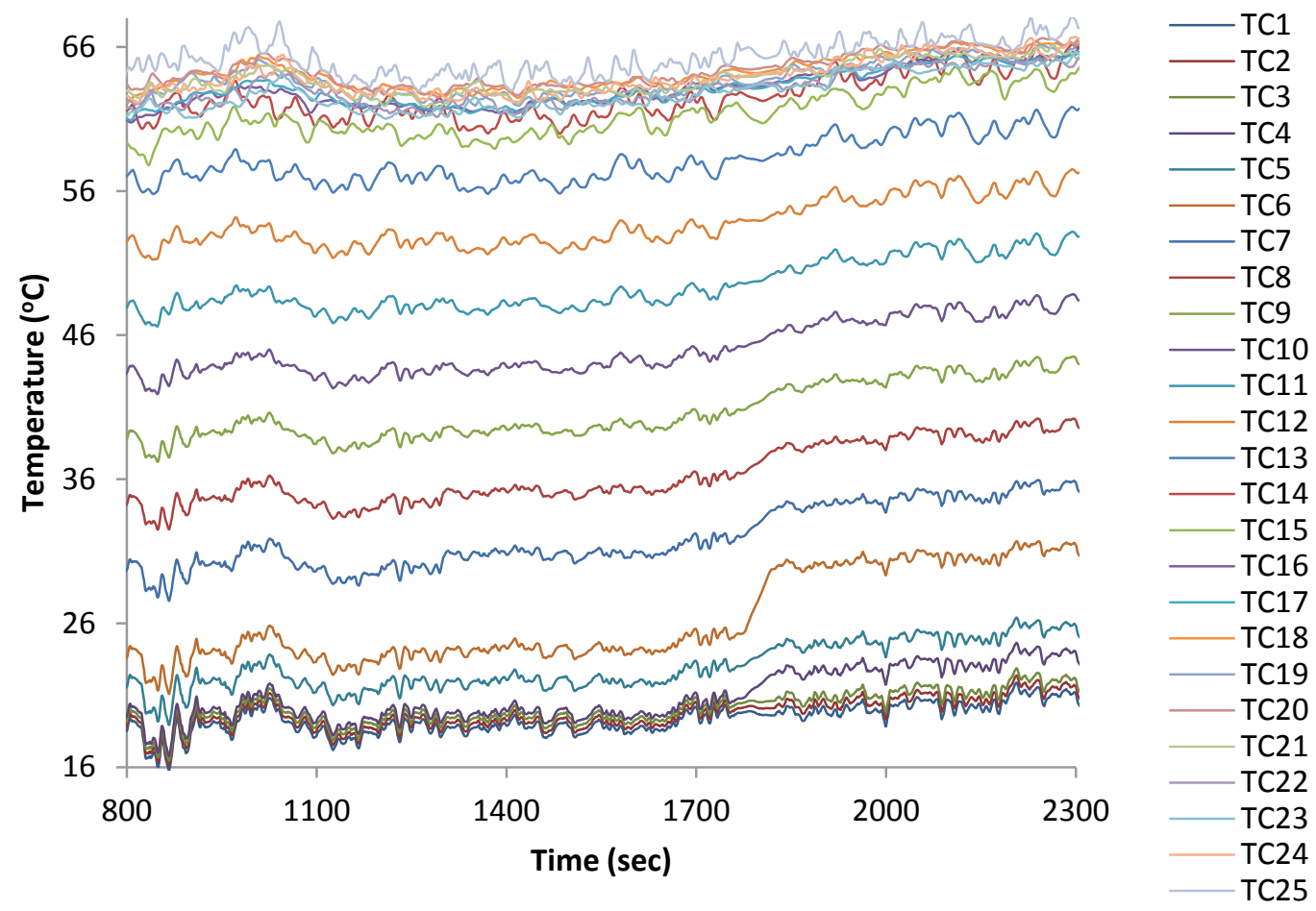

Figure 5-11 Temperature variation for the 5 MW fire test 


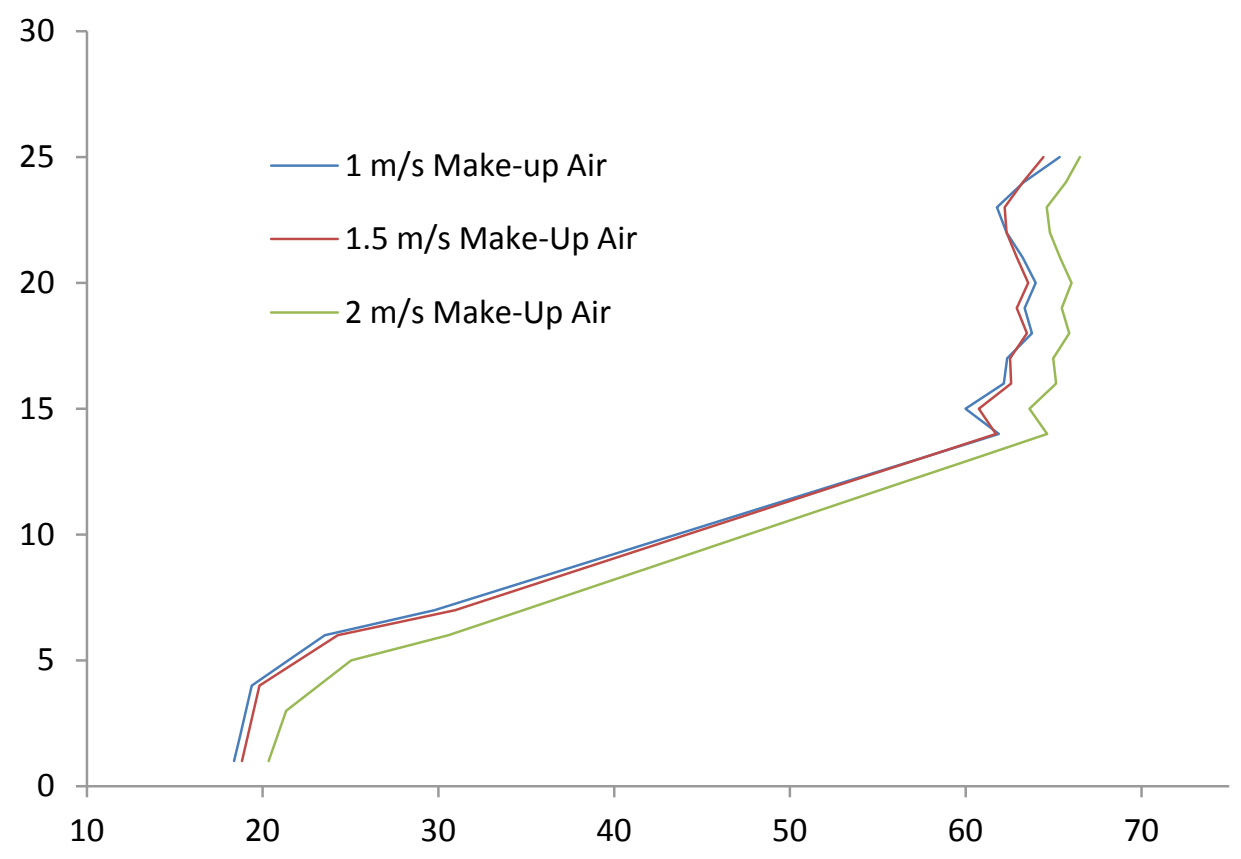

Figure 5-12 Vertical temperature profiles for the $5 \mathrm{MW}$ fire test

Figure 5-13 shows the average hot layer temperature, cold layer temperature and the first indication of hot layer temperature during the steady state condition in the atrium. 


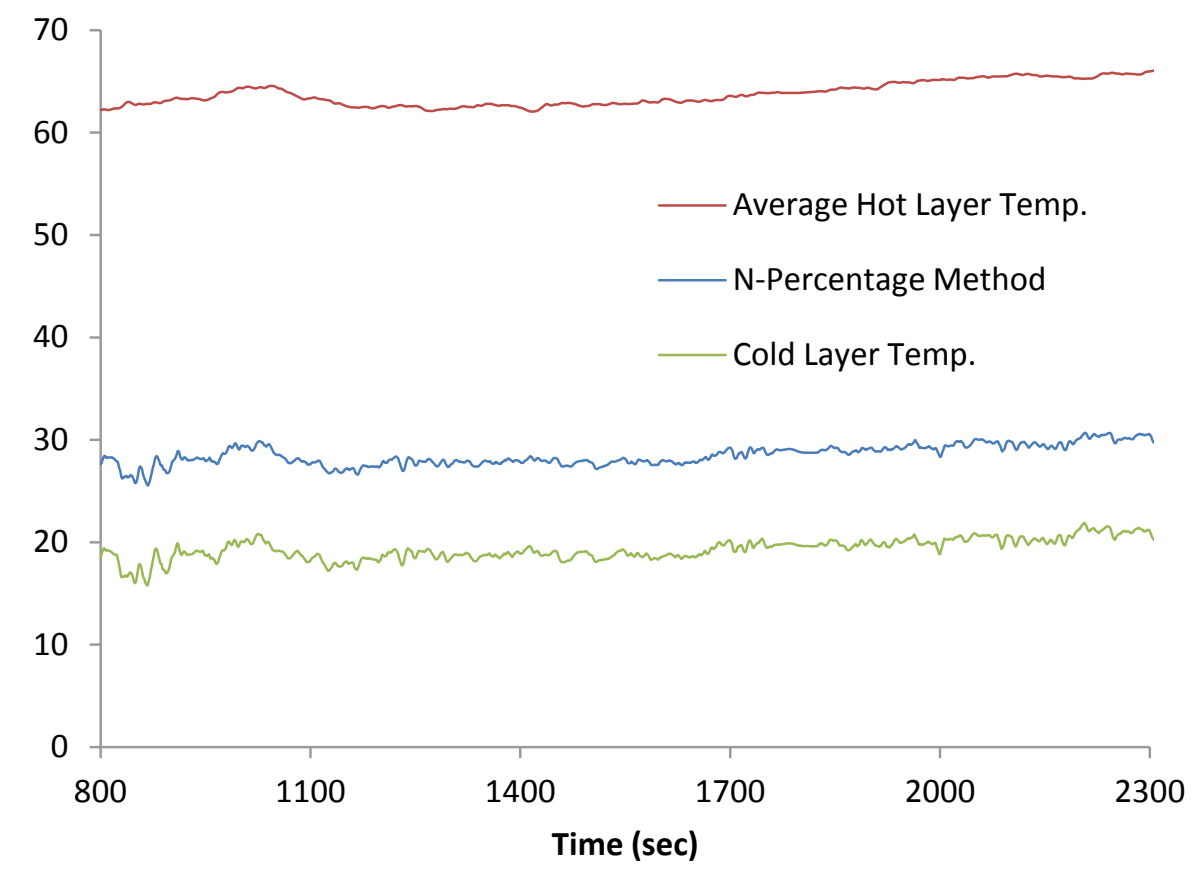

Figure 5-13 Hot layer, cold layer and interface temperature for the 5 MW fire test

The average smoke layer height over the $200 \mathrm{sec}$ of each steady condition at different points is shown in Table 5-4. The average of all four points shows that the smoke layer descents with increasing make-up air velocity. Also, the mean deviation indicates that with increasing air velocity, the turbulence of the smoke movement increases. However, the effect of increasing the make-up air velocity on the smoke layer height is not significant for the $5 \mathrm{MW}$ fire test. 
Table 5-4 Smoke layer height at different points in 5 MW fire tests

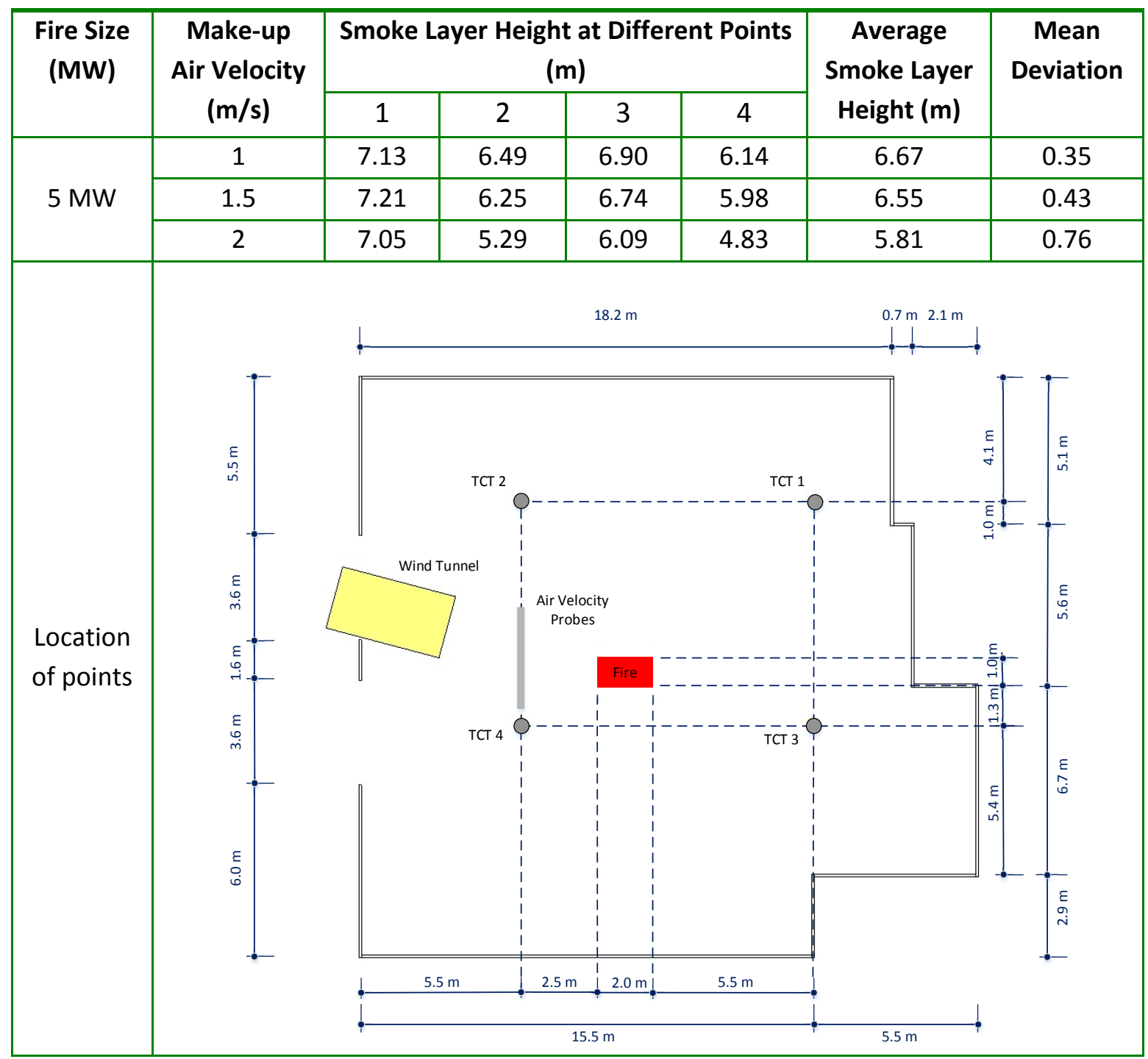




\subsection{Discussion of Experimental Results}

A comparison between the effect of $1,1.5$ and $2 \mathrm{~m} / \mathrm{s}$ make-up air velocity on the smoke layer height for the $1 \mathrm{MW}$ fire test is shown in Table 5-5 and plotted in Figure 5-14. The figure shows that the effect of the $2 \mathrm{~m} / \mathrm{s}$ air velocity is more pronounced than the $1.5 \mathrm{~m} / \mathrm{s}$. The smoke layer height is $10.77 \mathrm{~m}$ for the $1 \mathrm{~m} / \mathrm{s}$ make-up air velocity. It drops to $9.84 \mathrm{~m}$ when the velocity increases to $1.5 \mathrm{~m} / \mathrm{s}$ and to $6.98 \mathrm{~m}$ when the velocity rises to $2 \mathrm{~m} / \mathrm{s}$.

Table 5-5 The effect of make-up air velocity on smoke layer height in $1 \mathrm{MW}$ fire test

\begin{tabular}{|c|c|c|c|c|c|}
\hline \multicolumn{6}{|c|}{ Smoke Layer height } \\
\hline & & Correlations & & Experiments & \\
\hline \multirow[t]{2}{*}{ Fire Test } & $\begin{array}{c}\text { Make-up } \\
\text { Air Velocity }\end{array}$ & $\begin{array}{l}\text { Design } \\
\text { (m) }\end{array}$ & $\begin{array}{c}\text { Visual } \\
\text { Observation } \\
\text { (m) }\end{array}$ & $\begin{array}{c}\text { N-Percentage } \\
\text { Method } \\
\text { (m) }\end{array}$ & Normalized \\
\hline & $1 \mathrm{~m} / \mathrm{s}$ & 12.93 & 11 & 10.77 & 1.00 \\
\hline \multirow[t]{2}{*}{$1 \mathrm{MW}$} & $1.5 \mathrm{~m} / \mathrm{s}$ & 12.93 & 10 & 9.84 & 0.91 \\
\hline & $2 \mathrm{~m} / \mathrm{s}$ & 12.93 & 7 & 6.98 & 0.65 \\
\hline
\end{tabular}

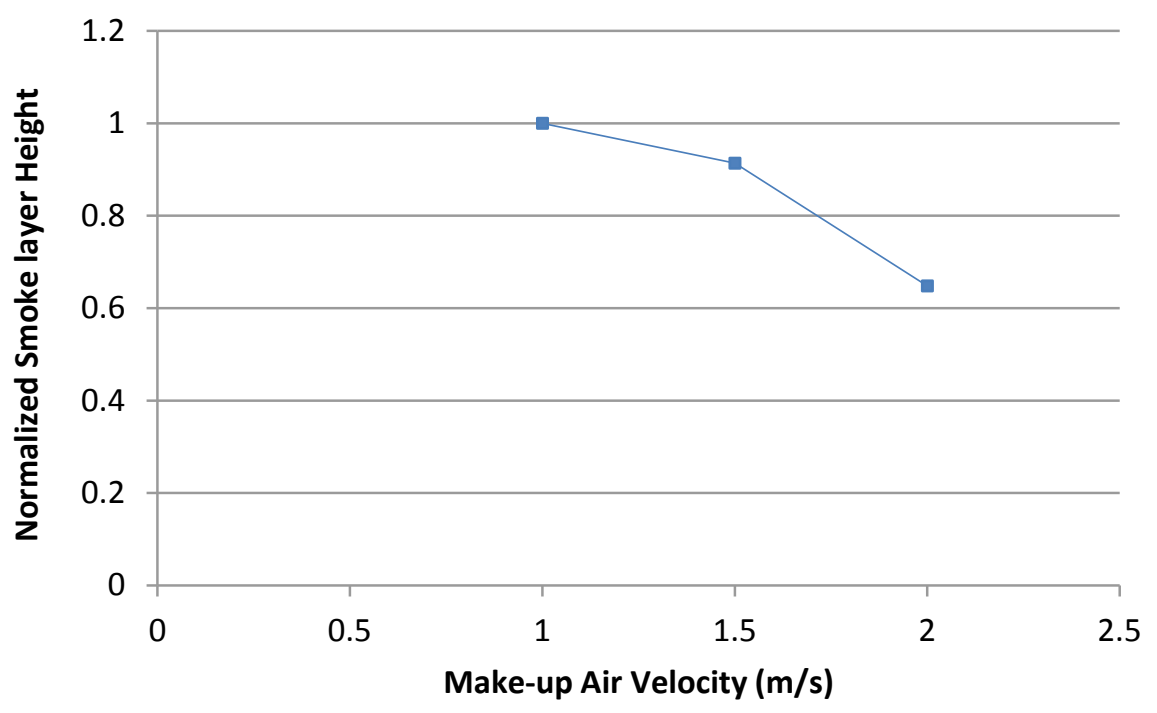

Figure 5-14 Normalized smoke layer height in 1 MW fire test 
The average smoke layer height of 2 MW fire test is shown in Table 5-6 and the normalized smoke layer height is plotted in Figure 5-15. The table indicates that the smoke layer height for the $2 \mathrm{MW}$ fire decreases with increasing make up air velocity. It drops from $9.08 \mathrm{~m}$ to $8.19 \mathrm{~m}$ when the velocity increases from 1 to $1.5 \mathrm{~m} / \mathrm{s}$ and decreases from $8.19 \mathrm{~m}$ to $6.34 \mathrm{~m}$ when the make-up air velocity increases to $2 \mathrm{~m} / \mathrm{s}$. The effect of the $2 \mathrm{~m} / \mathrm{s}$ air velocity is more pronounced than the $1.5 \mathrm{~m} / \mathrm{s}$ as shown in Figure 5-15.

Table 5-6 The effect of make-up air velocity on smoke layer height in 2 MW fire test

\begin{tabular}{|c|c|c|c|c|c|}
\hline \multicolumn{6}{|c|}{ Smoke Layer height } \\
\hline & & Correlations & & Experiments & \\
\hline \multirow[t]{2}{*}{ Fire Test } & $\begin{array}{c}\text { Make-up } \\
\text { Air Velocity }\end{array}$ & $\begin{array}{l}\text { Design } \\
\text { (m) }\end{array}$ & $\begin{array}{c}\text { Visual } \\
\text { Observation } \\
\text { (m) }\end{array}$ & $\begin{array}{c}\text { N-Percentage } \\
\text { Method } \\
\text { (m) }\end{array}$ & Normalized \\
\hline & $1 \mathrm{~m} / \mathrm{s}$ & 11.2 & 9.5 & 9.08 & 1.00 \\
\hline \multirow[t]{2}{*}{$2 \mathrm{MW}$} & $1.5 \mathrm{~m} / \mathrm{s}$ & 11.2 & 8 & 8.19 & 0.90 \\
\hline & $2 \mathrm{~m} / \mathrm{s}$ & 11.2 & 7 & 6.34 & 0.70 \\
\hline
\end{tabular}

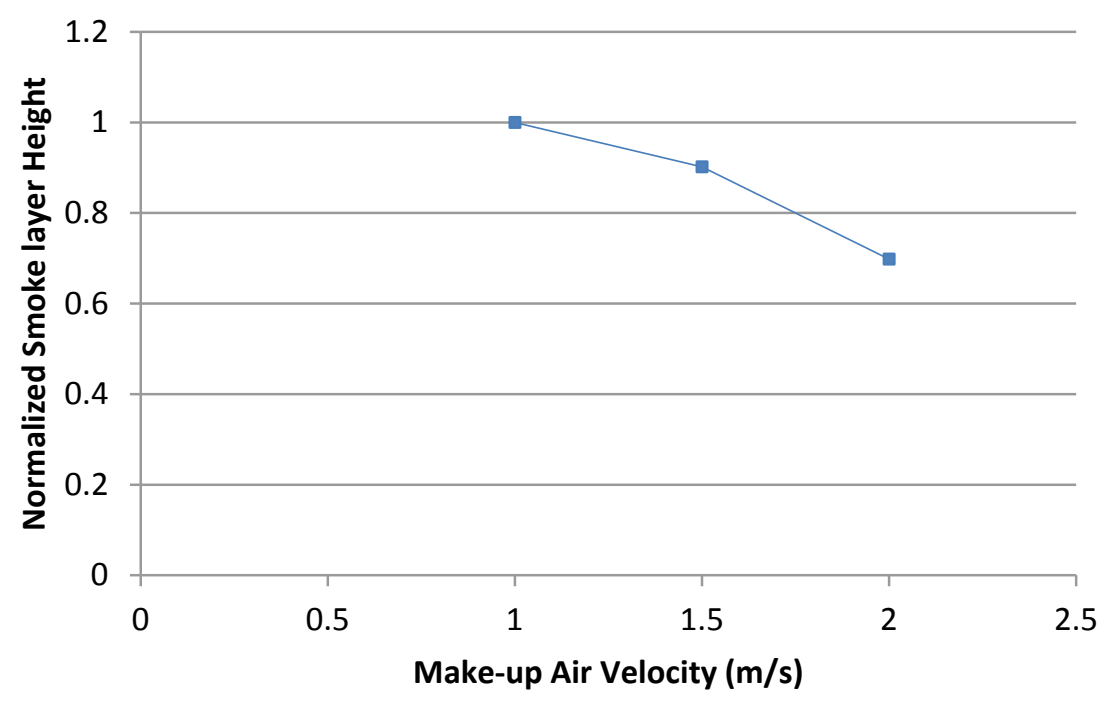

Figure 5-15 Normalized smoke layer height in 2 MW fire test 
A comparison between the effects of make-up air velocity on smoke layer height for the $5 \mathrm{MW}$ fire test is shown in Table 5-7. It is interesting to see that increasing the make-up air velocity from $1 \mathrm{~m} / \mathrm{s}$ to $1.5 \mathrm{~m} / \mathrm{s}$ does not have a big effect on smoke layer height for this test. Also the reduction rate of the normalized values is less than the reduction rate for the 1 and 2 MW fires as shown in Figure 5-16.

Table 5-7 The effect of make-up air velocity on smoke layer height in 5 MW fire test

\begin{tabular}{|c|c|c|c|c|c|}
\hline \multicolumn{6}{|c|}{ Smoke Layer height } \\
\hline & & Correlations & & Experiments & \\
\hline \multirow[t]{2}{*}{ Fire Test } & $\begin{array}{c}\text { Make-up } \\
\text { Air Velocity }\end{array}$ & $\begin{array}{l}\text { Design } \\
\text { (m) }\end{array}$ & $\begin{array}{c}\text { Visual } \\
\text { Observation } \\
\text { (m) }\end{array}$ & $\begin{array}{c}\text { N-Percentage } \\
\text { Method } \\
\text { (m) }\end{array}$ & Normalized \\
\hline & $1 \mathrm{~m} / \mathrm{s}$ & 9 & 6.5 & 6.67 & 1.00 \\
\hline \multirow[t]{2}{*}{$5 \mathrm{MW}$} & $1.5 \mathrm{~m} / \mathrm{s}$ & 9 & 6.5 & 6.55 & 0.98 \\
\hline & $2 \mathrm{~m} / \mathrm{s}$ & 9 & 6 & 5.81 & 0.87 \\
\hline
\end{tabular}

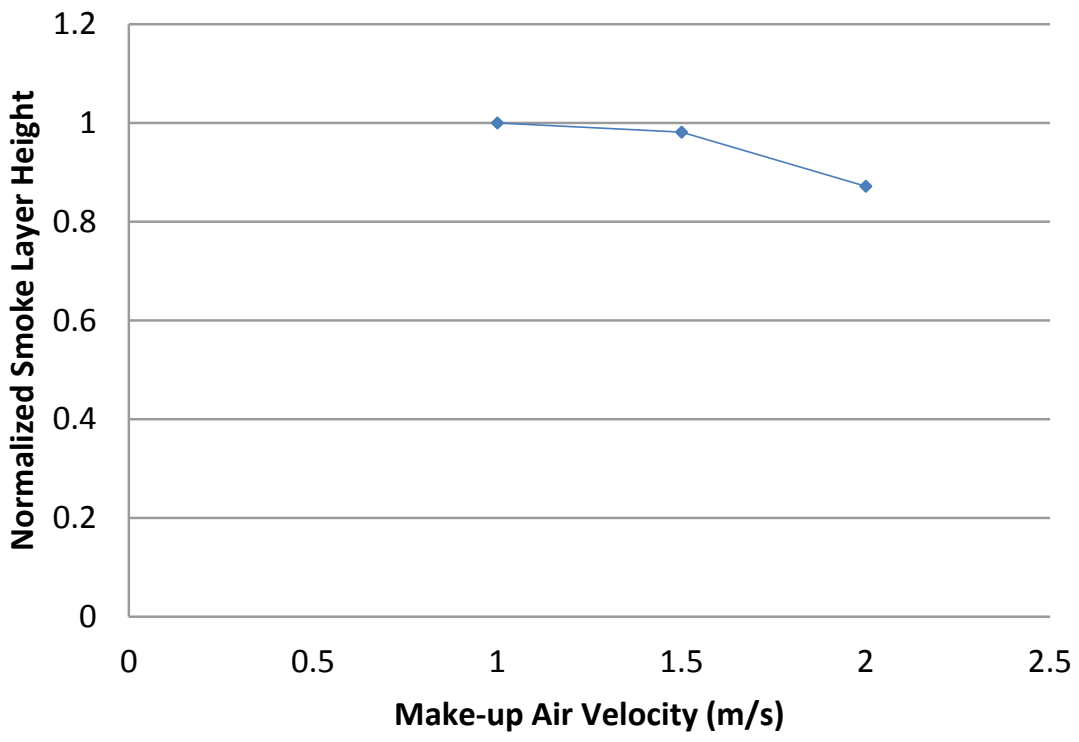

Figure 5-16 Normalized smoke layer height in 5 MW fire test 


\subsection{Simulation Results}

FDS 5.0 (McGrattan et al., 2010) and Smokeview (Forney, 2010) have been used for modelling of atrium fire tests. In order to establish a grid that ensured a grid independent solution, simulations using different grid sizes were conducted to find the most efficient grid size. The geometry of the model was the same as the facility and the smoke height measuring device has been modeled at the same locations as the thermocouple trees in the experiments to take the smoke layer interface height exactly at the same place as N-Percentage method prediction.

A total of nine FDS simulations were carried out with 1,2 and $5 \mathrm{MW}$ fires at the middle of the atrium exposed to 1, 1.5, 2 and $3 \mathrm{~m} / \mathrm{s}$ make-up air velocities. A grid with dimensions of $0.26 \mathrm{~m} \times 0.26 \mathrm{~m} \times 0.26 \mathrm{~m}$ was applied to the entire computational domain. The fans were modeled as vents with constant volumetric flow rates. The fan system was simulated to run at $33 \mathrm{~m}^{3} / \mathrm{s}$. The smoke layer interface height has been measured with Janssens and Tran method (1992). 


\subsubsection{MW Fire Test Simulation}

The average of smoke layer height over the last $200 \mathrm{sec}$ for each test at different points from the modelling results is shown in Table 5-8. The average smoke layer height of all four points indicates that the effect of changing the make-up air velocity from 1.5 to 2 $\mathrm{m} / \mathrm{s}$ and from 2 to $3 \mathrm{~m} / \mathrm{s}$ on smoke layer height is considerably more than changing from 1 to $1.5 \mathrm{~m} / \mathrm{s}$. Moreover, the mean deviation shows the disturbance in smoke layer height increases with increasing the air velocity. These observations were also made from the experimental data. Figure 5-17 shows the temperature distribution of CFD modelling of the $1 \mathrm{MW}$ fire test on a plane passing through the points 1 and 2 . 
Table 5-8 Smoke layer height at different points in CFD modelling of $1 \mathrm{MW}$ fire tests

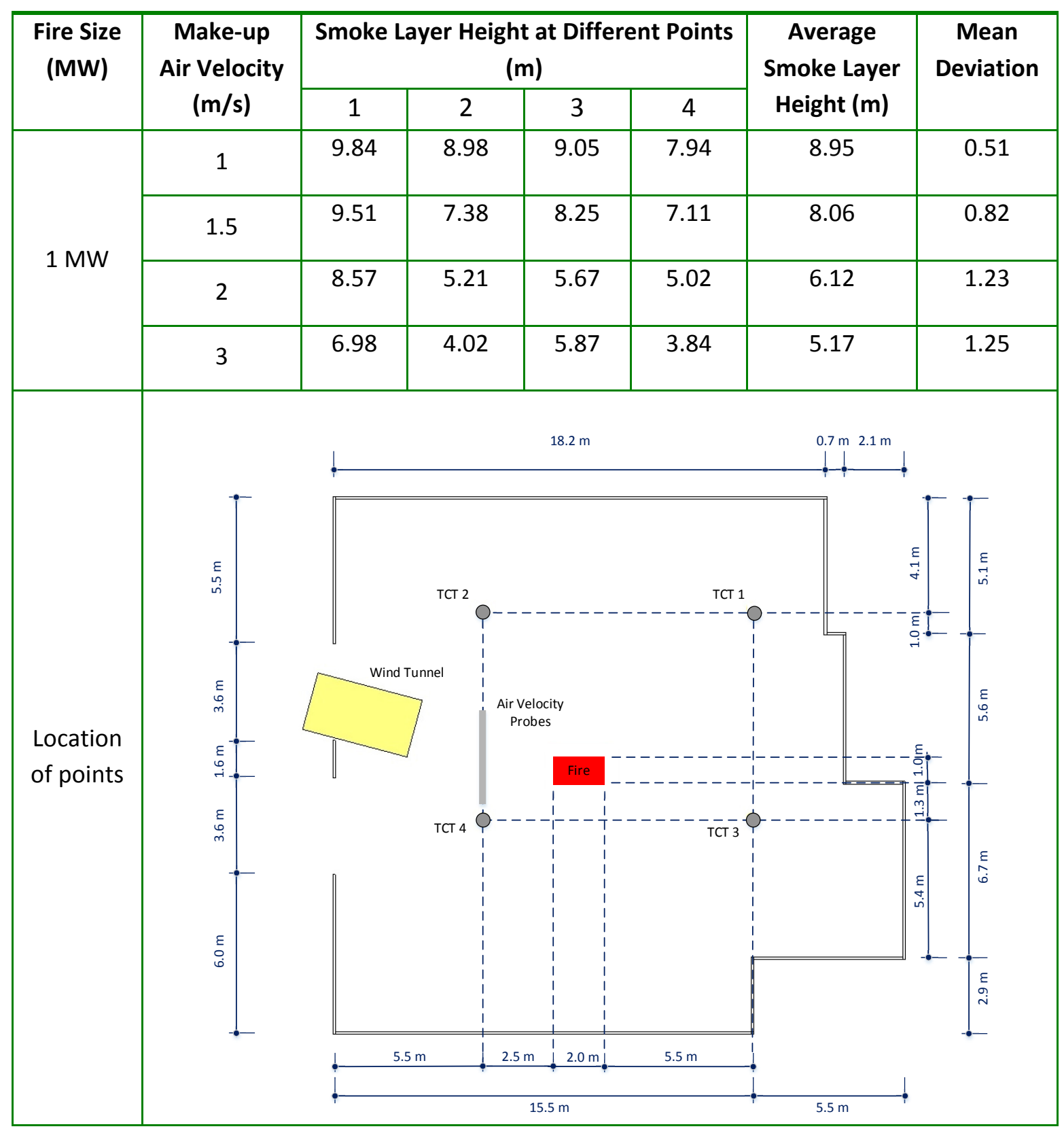




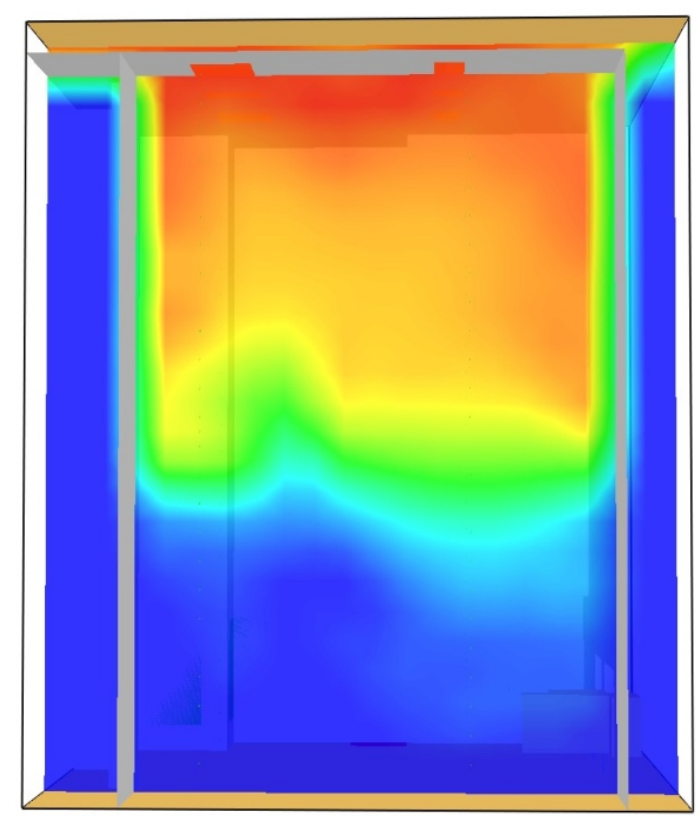

a. $1 \mathrm{~m} / \mathrm{s}$ make-up air test

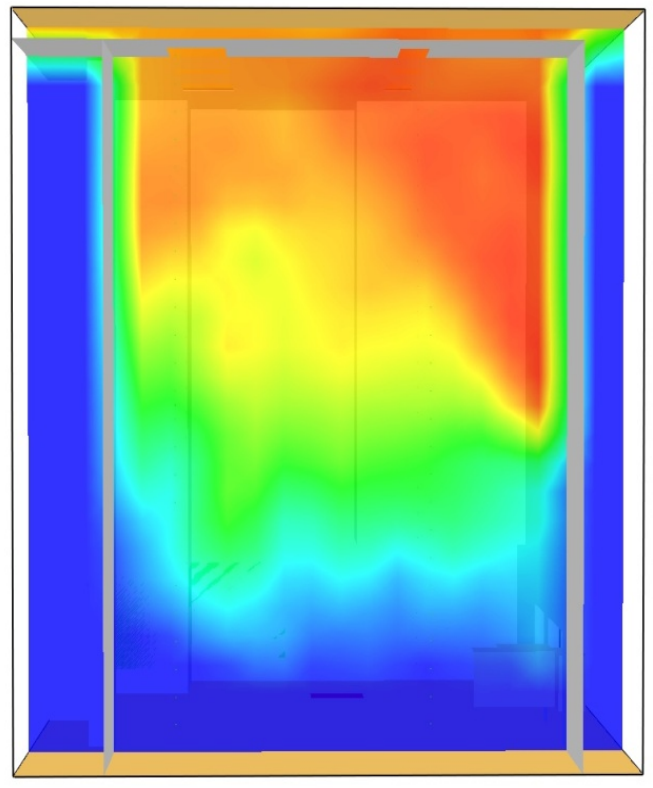

c. $2 \mathrm{~m} / \mathrm{s}$ make-up air test

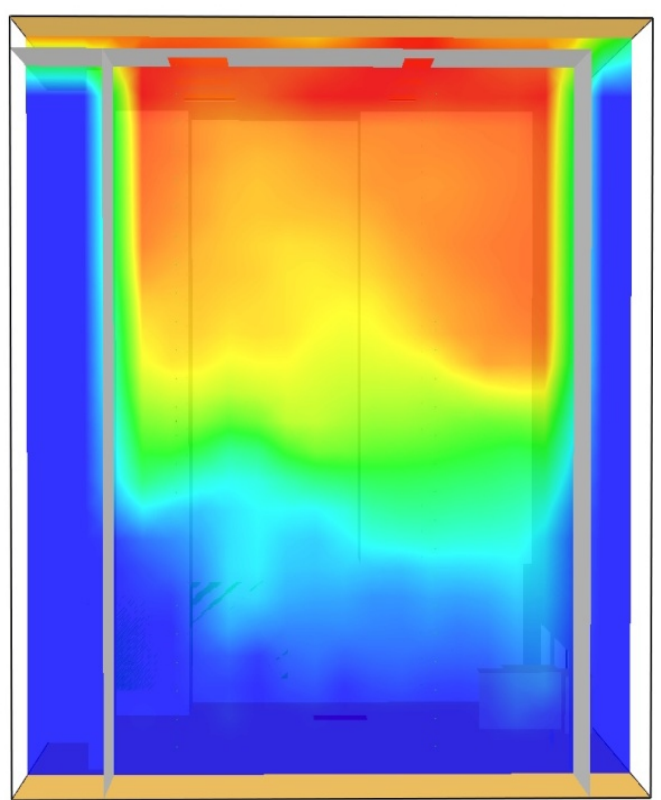

b. $1.5 \mathrm{~m} / \mathrm{s}$ make-up air test

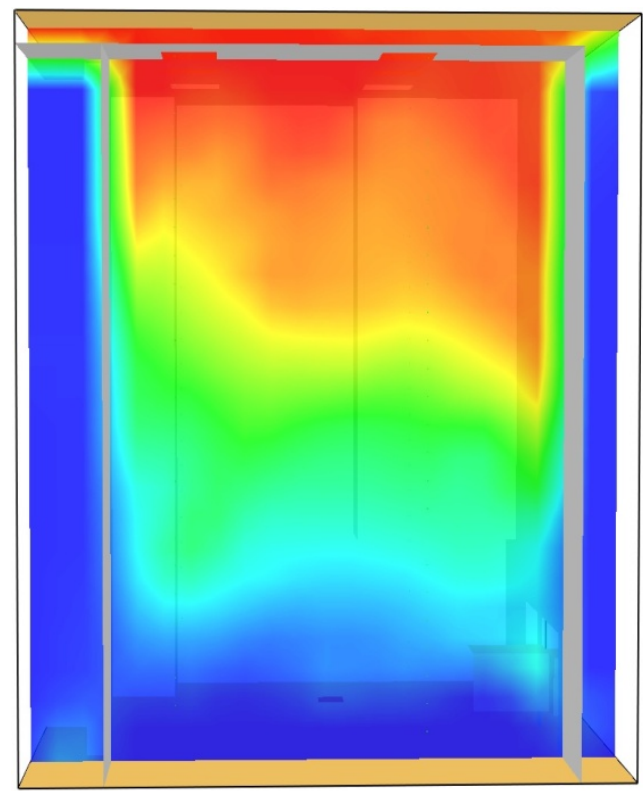

d. $3 \mathrm{~m} / \mathrm{s}$ make-up air test

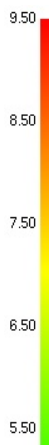

4.50

Figure 5-17 Predicted temperature contours for the 1 MW fire on a vertical plane through points 


\subsubsection{MW Fire Test Simulation}

Table 5-9 shows the average smoke layer height over the last $200 \mathrm{sec}$ for each test at different points for CFD modelling of the $2 \mathrm{MW}$ fire test. The average of all four points indicates that the decrease in smoke layer height is more when the air velocity increases to $2 \mathrm{~m} / \mathrm{s}$ and $3 \mathrm{~m} / \mathrm{s}$ than $1.5 \mathrm{~m} / \mathrm{s}$. In addition, the mean deviation shows that the turbulence in smoke movement rises with increasing the make-up air velocity. Figure 518 shows the CFD predicted temperature distribution of the $2 \mathrm{MW}$ fire test on a plane passing through the points 1 and 2 . 
Table 5-9 Smoke layer height at different points in CFD modelling of 2 MW fire tests

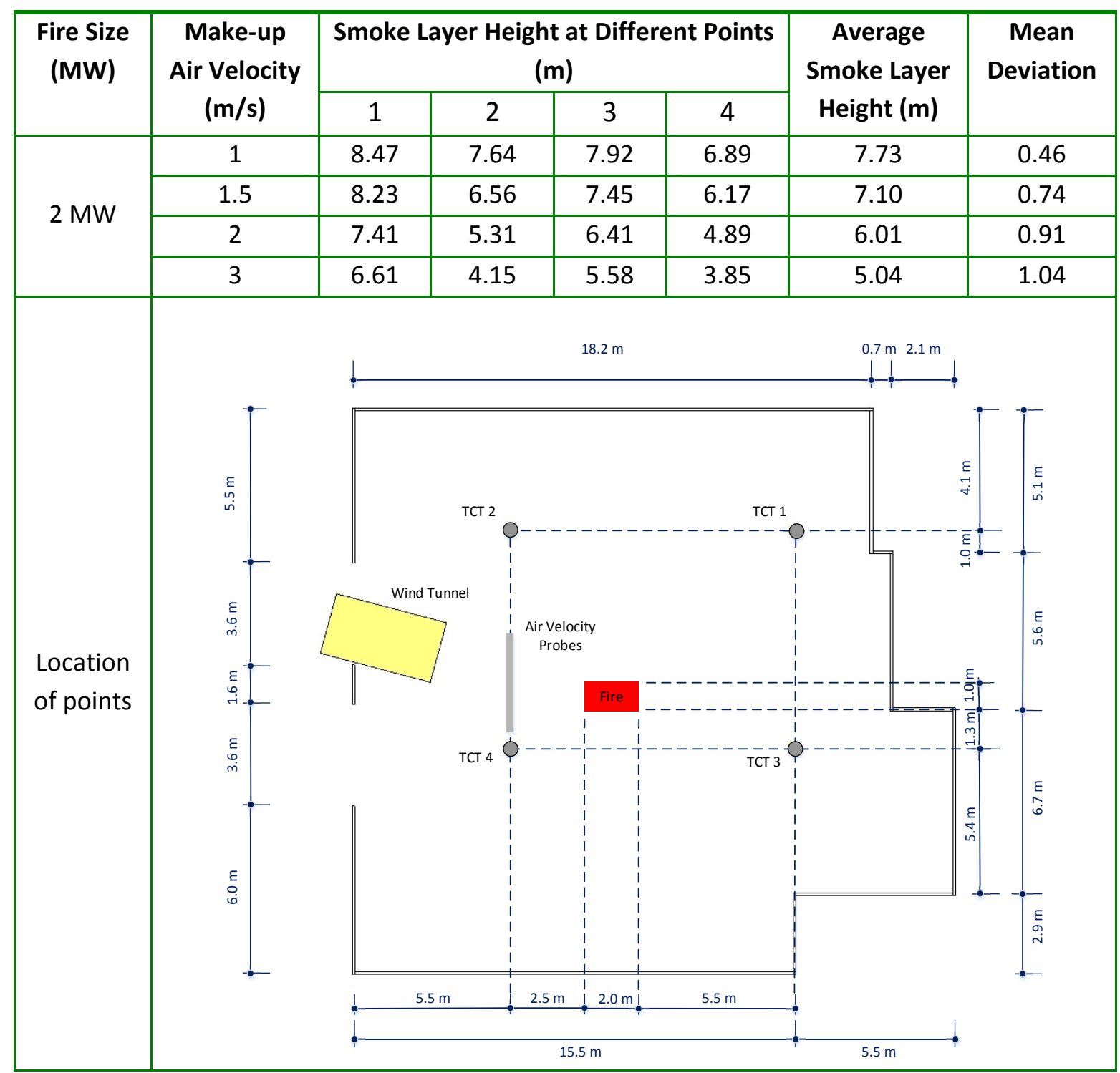




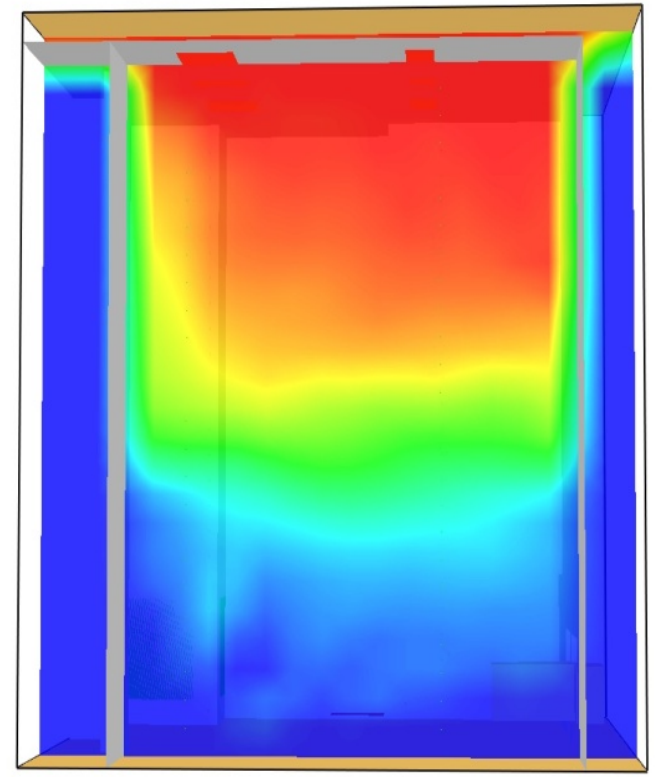

a. $1 \mathrm{~m} / \mathrm{s}$ make-up air test

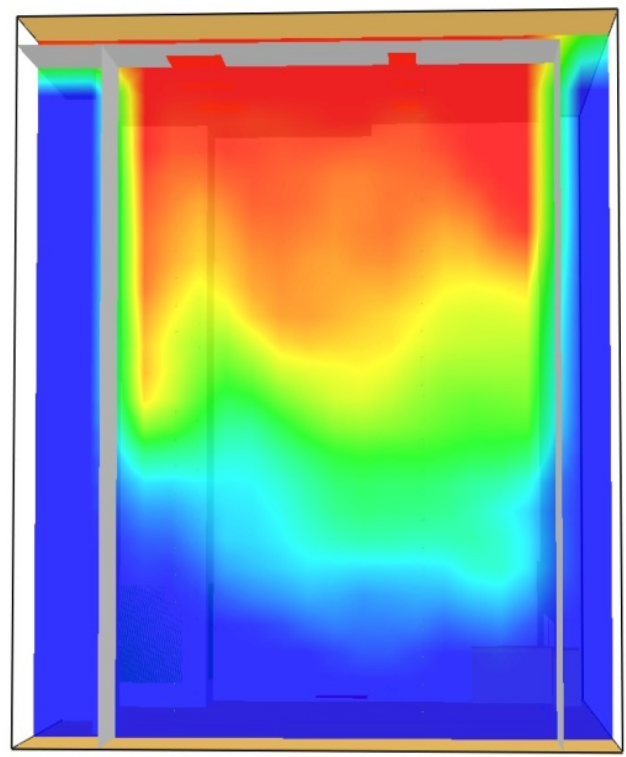

c. $2 \mathrm{~m} / \mathrm{s}$ make-up air test

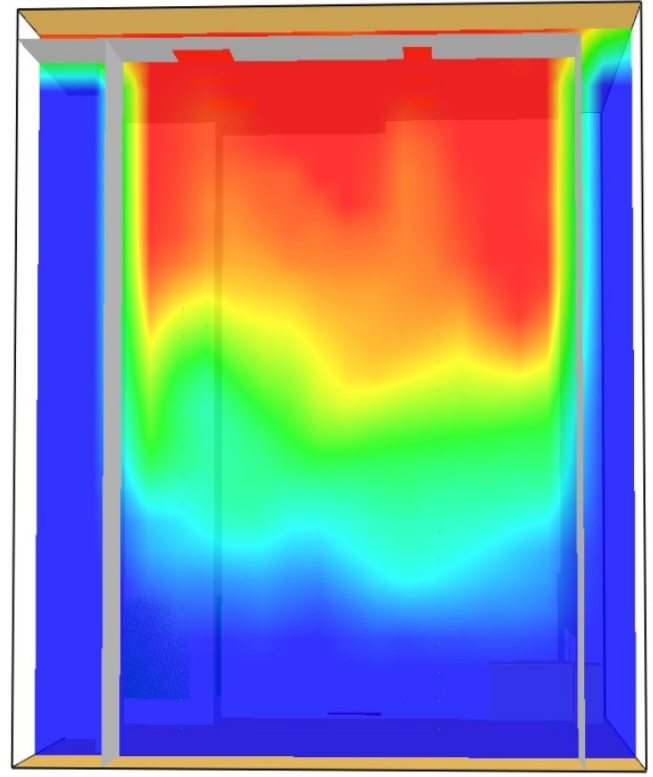

b. $1.5 \mathrm{~m} / \mathrm{s}$ make-up air test

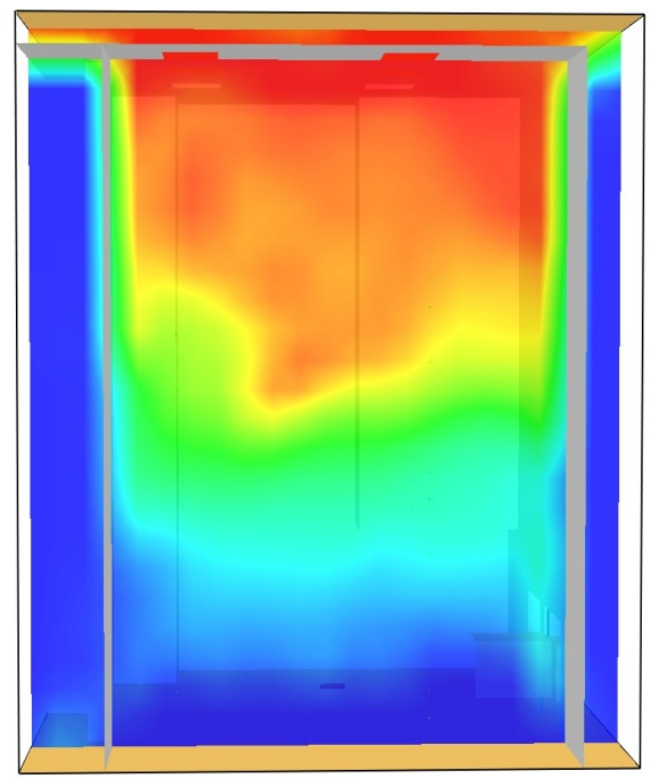

d. $3 \mathrm{~m} / \mathrm{s}$ make-up air test
19.5
17.5
15.5
13.5

11.5

9.50

7.50

5.50

3.50

1.50

Figure 5-18 Predicted temperature contours for the 2 MW fire on a vertical plane through points 


\subsubsection{MW Fire Test Simulation}

The average of smoke layer height over the last $200 \mathrm{sec}$ for each steady condition in CFD modelling of $5 \mathrm{MW}$ fire is shown in Table 5-10. The average smoke layer height indicates that the change in smoke interface is not considerable for increasing the air velocity to 1.5 and $2 \mathrm{~m} / \mathrm{s}$, however the smoke layer descends with raising the air velocity to $3 \mathrm{~m} / \mathrm{s}$ in the $5 \mathrm{MW}$ fire test. Also the mean deviation shows increasing the make-up air velocity does not cause a significant turbulence in smoke conditions in the

atrium. Figure 5-19 shows the predicted temperature distribution for the $5 \mathrm{MW}$ fire test on a plane passing through points 1 and 2 . 
Table 5-10 Smoke layer height at different points in CFD modelling of $5 \mathrm{MW}$ fire tests

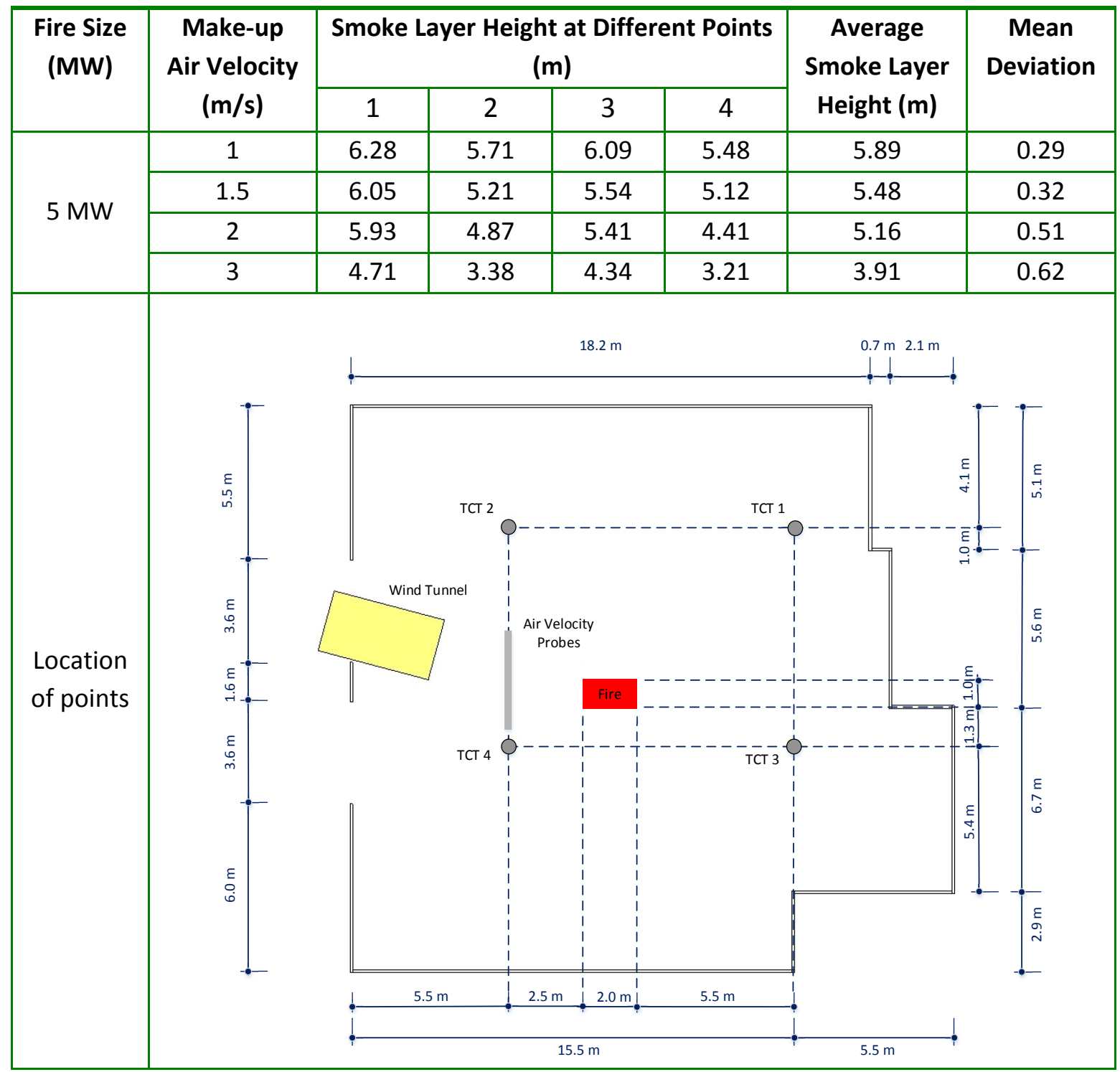




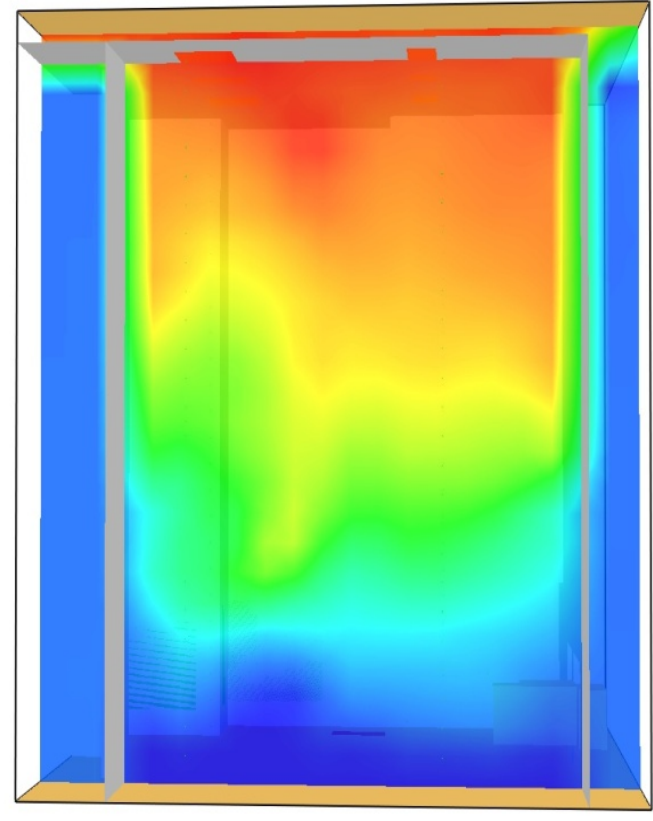

a. $1 \mathrm{~m} / \mathrm{s}$ make-up air test

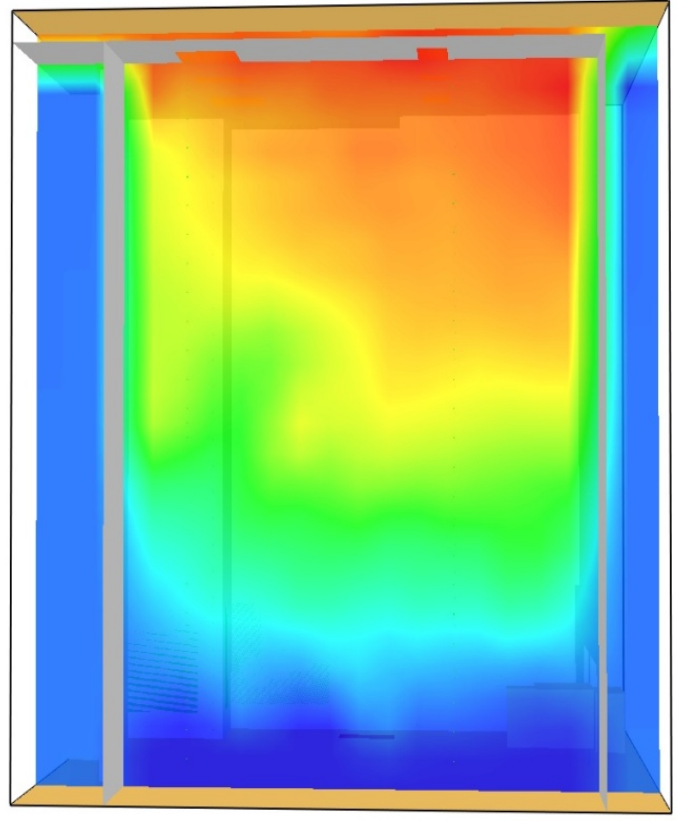

c. $2 \mathrm{~m} / \mathrm{s}$ make-up air test

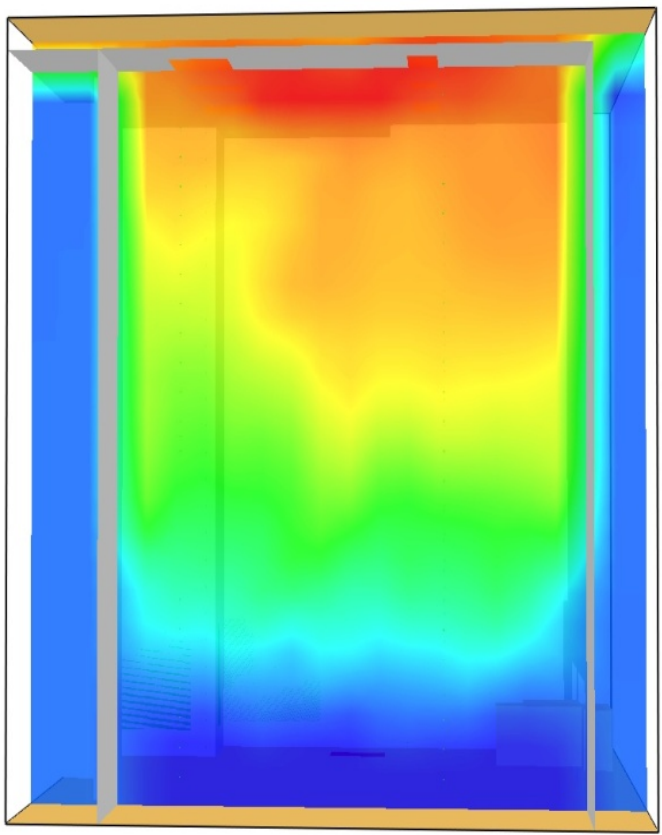

b. $1.5 \mathrm{~m} / \mathrm{s}$ make-up air test

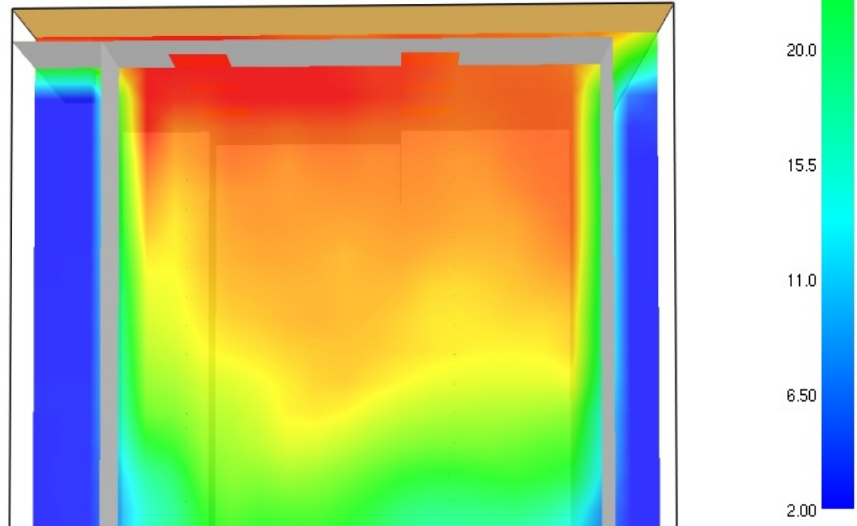

d. $3 \mathrm{~m} / \mathrm{s}$ make-up air test

Figure 5-19 Predicted temperature contours for the $5 \mathrm{MW}$ fire on a vertical plane through points 


\subsection{Discussion of Simulation Results}

Table 5-11 shows the average smoke layer height obtained from CFD modelling for the $1 \mathrm{MW}$ fire tests. The smoke layer height drops from $8.95 \mathrm{~m}$ to $8.06 \mathrm{~m}$ when the makeup air velocity increases from 1.0 to $1.5 \mathrm{~m} / \mathrm{s}$, from $8.06 \mathrm{~m}$ to $6.12 \mathrm{~m}$ when the air velocity increases to $2.0 \mathrm{~m} / \mathrm{s}$ and from $6.12 \mathrm{~m}$ to 5.17 when the air velocity increase to 3 $\mathrm{m} / \mathrm{s}$. In addition, the reduction rate in smoke layer height decreases with increasing the air velocity to $3 \mathrm{~m} / \mathrm{s}$. Figure $5-20$ depicts the normalized smoke layer height. It is interesting to see the reduction rate of the normalized value from the CFD modelling compares well with the normalized values from the full-scale experiments. The CFD modelling, however predicts lower smoke layer heights.

Table 5-11 The effect of make-up air velocity on smoke layer height in modelling of 1 MW fire test

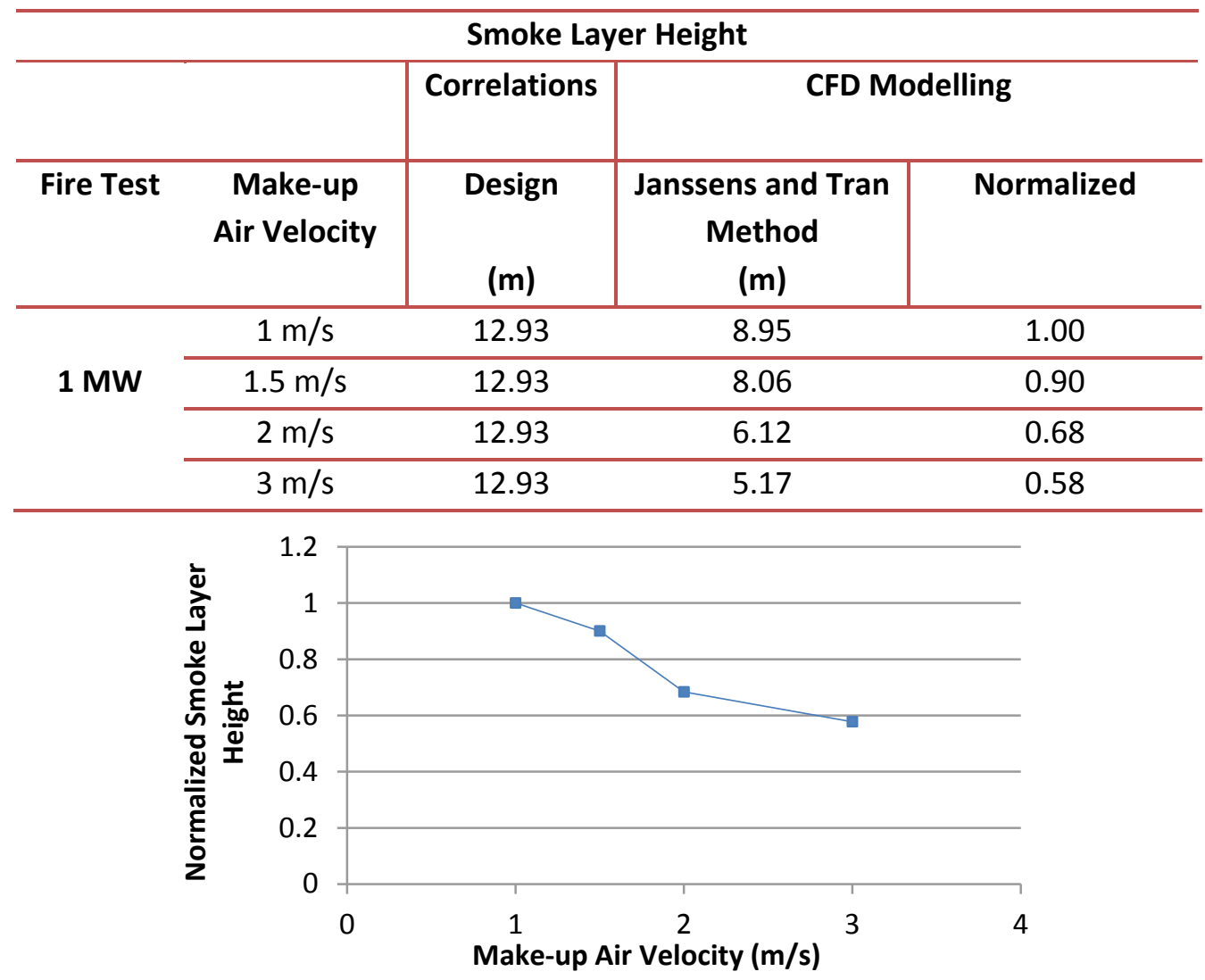

Figure 5-20 Normalized smoke layer height in CFD modelling of 1 MW fire test 
The average smoke layer height from the CFD modelling of the $2 \mathrm{MW}$ fire is shown in Table 5-12 and the normalized value is plotted in Figure 5-21. The table indicates that the smoke layer height decreases from $7.73 \mathrm{~m}$ to $7.10 \mathrm{~m}$ when the air velocity increases from 1 to $1.5 \mathrm{~m} / \mathrm{s}$, from $7.10 \mathrm{~m}$ to $6.01 \mathrm{~m}$ with raising the air velocity to $2 \mathrm{~m} / \mathrm{s}$ and from $6.01 \mathrm{~m}$ to $5.04 \mathrm{~m}$ when the air velocity increases to $3 \mathrm{~m} / \mathrm{s}$. The smoke layer heights obtained from the simulation are lower than the values from experiments; however comparing the normalized value shows the reduction rate is quite similar.

Table 5-12 The effect of make-up air velocity on smoke layer height in modelling of 2 MW fire test

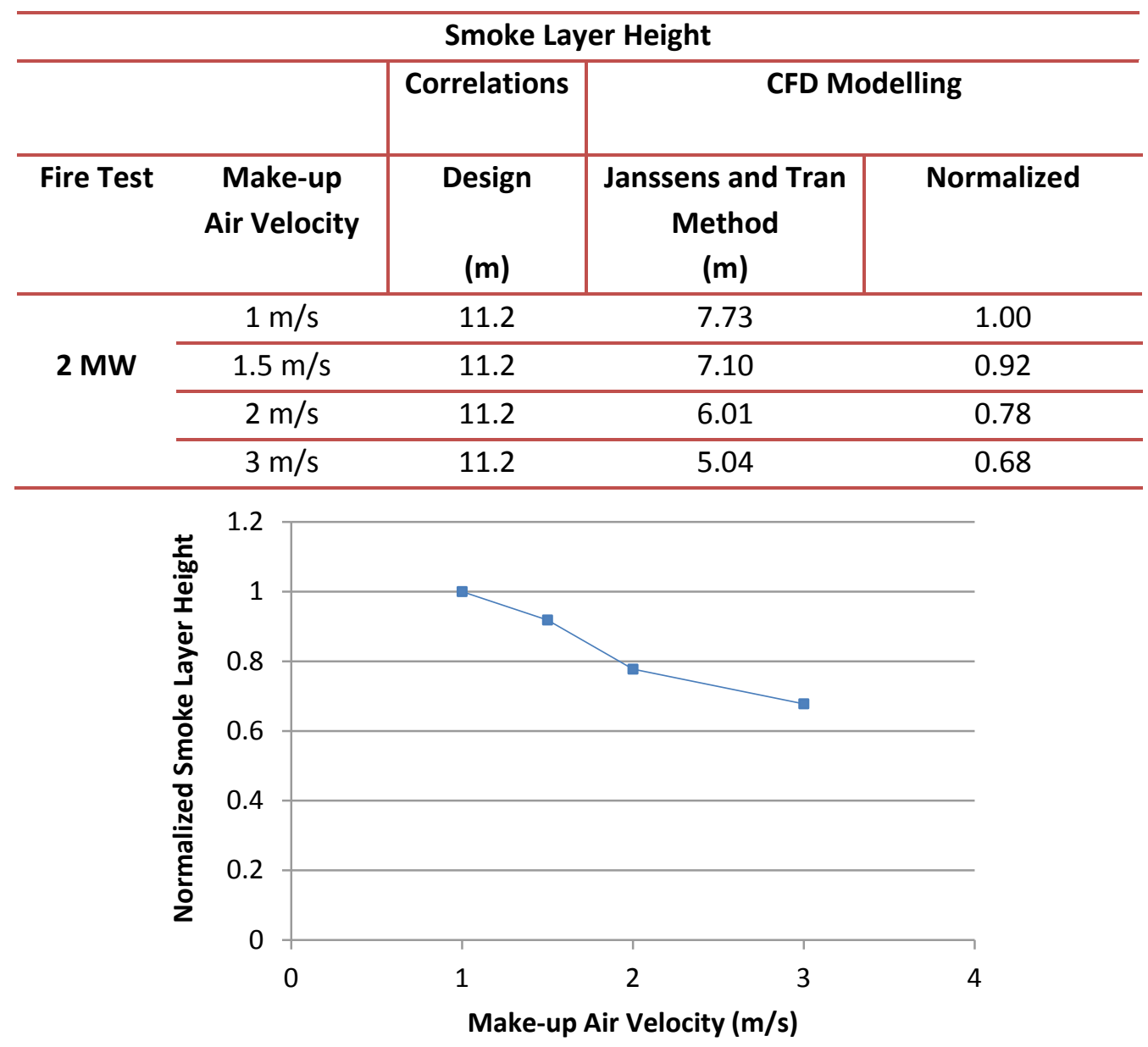

Figure 5-21 Normalized smoke layer height in CFD modelling of 2 MW fire test 
The smoke layer height decreases from $5.89 \mathrm{~m}$ to $5.48 \mathrm{~m}$ when the air velocity increases to $1.5 \mathrm{~m} / \mathrm{s}$, from $5.48 \mathrm{~m}$ to $5.16 \mathrm{~m}$ when the air velocity increases to $2.0 \mathrm{~m} / \mathrm{s}$ and from $5.16 \mathrm{~m}$ to $3.91 \mathrm{~m}$ when it increases to $3 \mathrm{~m} / \mathrm{s}$. Therefore, the effect of increasing the make-up air velocity on the smoke layer height for the $5 \mathrm{MW}$ fire is less pronounced for the 1.5 and $2 \mathrm{~m} / \mathrm{s}$ air velocity than the effect for the 1 and $2 \mathrm{MW}$ fire tests. The model results compare well with the experimental data for the $5 \mathrm{MW}$ fire test. The reduction rate in smoke layer height when the make-up air increases from 1 to 1.5 $\mathrm{m} / \mathrm{s}$ is more than the experiment, however the smoke layer height is still closed to the value from the experiment. Table 5-13 shows the average smoke layer height and Figure 5-22 illustrates the normalized values for CFD modelling of $5 \mathrm{MW}$ fire test.

Table 5-13 The effect of make-up air velocity on smoke layer height in modelling of 5 MW fire test

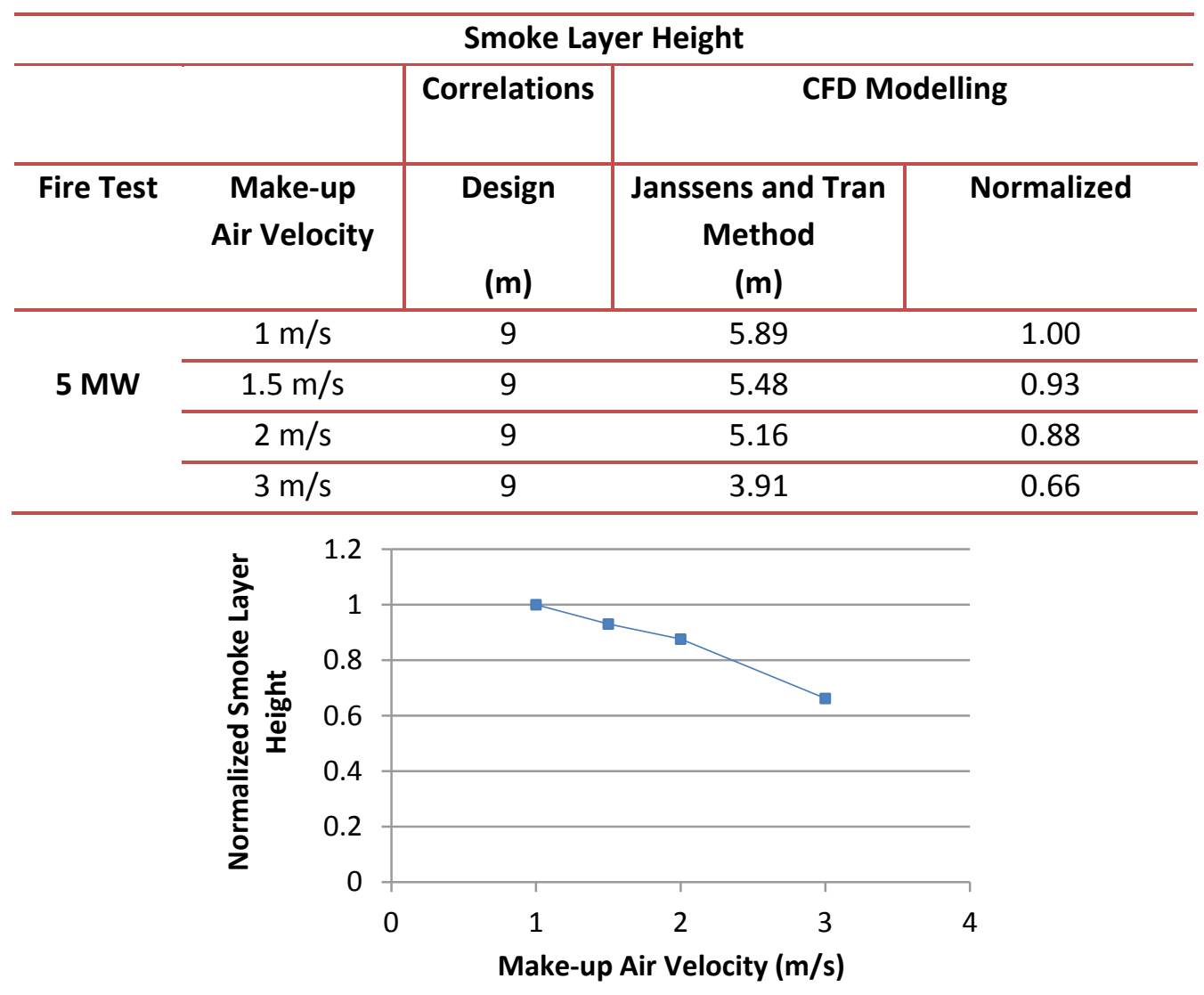

Figure 5-22 Normalized smoke layer height in CFD modelling of 5 MW fire test 


\subsection{Conclusion}

A comparison of the smoke layer heights from the experiments and simulations is shown in Figure 5-23. The N-percentage data represents the smoke layer height when $\mathrm{N}=0.2$. The inlet air velocity has been controlled using a wind tunnel and air velocity has been measured between the fire and the wind tunnel. The experimental results and simulations show a drop of the smoke layer height when the make-up air velocity is 2 $\mathrm{m} / \mathrm{s}$. The $1.5 \mathrm{~m} / \mathrm{s}$ air velocity does not always have a significant impact on the smoke layer interface height. In addition, the smoke layer drops more when the make-up air velocity is $2 \mathrm{~m} / \mathrm{s}$ for the small fire tests and when the make-up air velocity is $3 \mathrm{~m} / \mathrm{s}$ in the big fire test. This occurs because the combustion products can be easily spread out by the air in the small fires due to low buoyancy. The smoke layer heights from the experiments and simulations are lower than the correlation predictions. This may be because the opening location is near the fire and it is only on one side of the atrium.

The estimated smoke layer height from the N-percentage method compares well with the observations but CFD modelling overestimates the smoke depth for the 1 and $2 \mathrm{MW}$ fires. This may be due to higher entrainment rates in the smoke plume which cools the hot gases and increases the depth of the hot layer. 


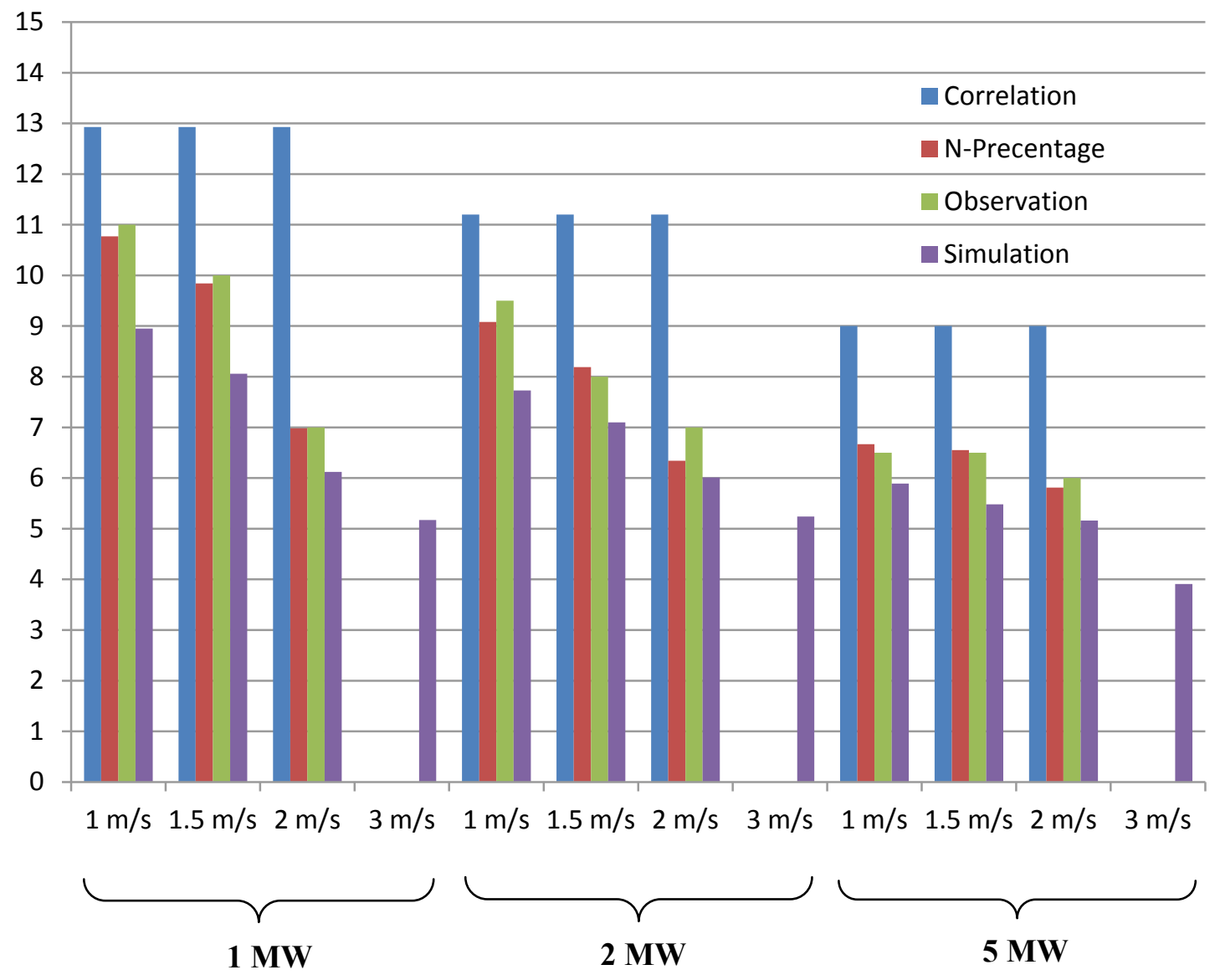

Fire Tests

Figure 5-23 Comparison of smoke layer height prediction methods 


\section{Chapter 6: Effects of Opening Arrangement on Atrium Smoke Conditions}

\subsection{Introduction}

This chapter presents the results of full-scale experiments and CFD modelling of atrium fires exposed to different opening arrangements. The tests considered the effect of different ventilation opening arrangements on the smoke conditions in the atrium for three fire sizes. FDS5 was used to simulate the atrium fires, and correlations have been employed to predict the smoke layer height. Five different configurations of openings in the atrium have been considered in this research including locating openings on four sides, three sides, two-opposite sides, two-adjacent sides and one side of the atrium, Figure 6-1. It was expected that the most severe case would be the case with the openings located on one side of the atrium as the flow of air towards the fire comes from one direction. It was expected that the least severe case would be the atrium with openings on all of its four sides.
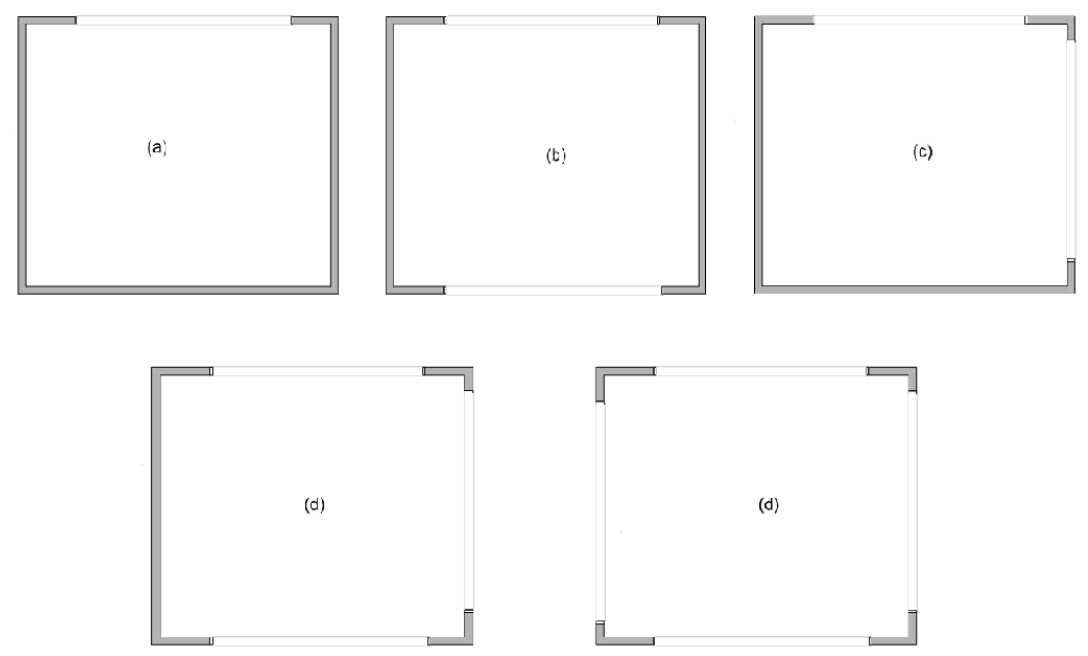

Figure 6-1 Schematic possible locations of openings 
Kerber and Milke (2007) investigated the impact of vent locations in the atrium by running several simulations with the numerical model Fire Dynamics Simulator (FDS) (McGrattan et al., 2010), including four sides and two-adjacent side openings with 1 and $2 \mathrm{~m} / \mathrm{s}$ make-up air velocity. Results showed that symmetrical arrangement of openings results in less turbulence in the smoke conditions in the atrium. Turbulence in smoke and plume conditions causes the height of the smoke layer to decrease. Figure 62 shows the effect of opening arrangement on the smoke layer height. This effect however has not been studied under different conditions and especially considering the effect of make-up air entry locations.

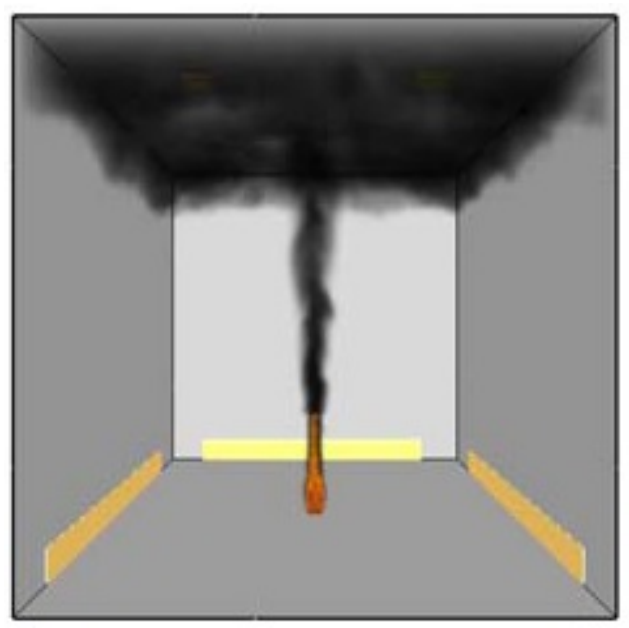

a. four sides openings

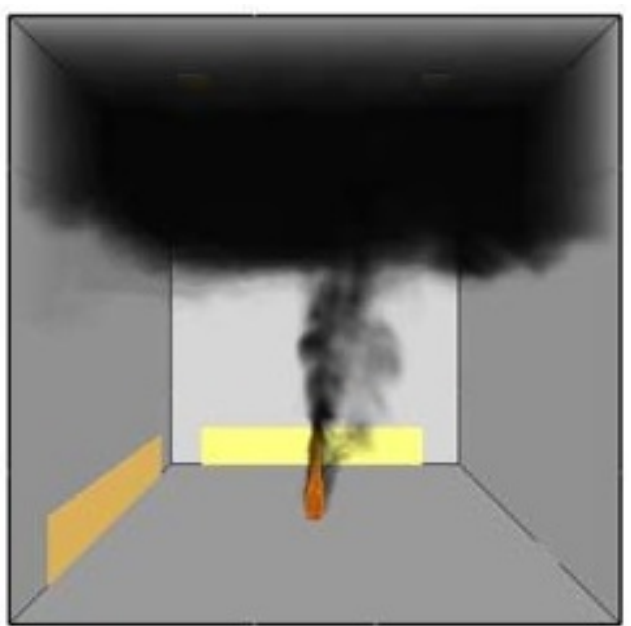

b. two-adjacent sides openings

Figure 6-2 Effect of opening arrangement on smoke layer height in CFD modeling (Kerber and Milke 2007)

\subsection{Atrium Geometry and Instrumentation}

In order to visually monitor the smoke development in the atrium, a $25 \mathrm{~m}$ long measuring tape was constructed and installed from the floor to the ceiling and three video cameras were used to record the smoke conditions in the atrium. Moreover, four 
thermocouple trees were installed in the atrium to record the temperature during the tests. Each thermocouple tree contained 25 thermocouples placed at every one meter along the atrium height. The thermocouples have been protected to minimize the effect of direct radiation from the flames. Figure 6-3 illustrates the atrium geometry and the location of thermocouple trees in the atrium. The openings have been labeled with numbers in this figure.

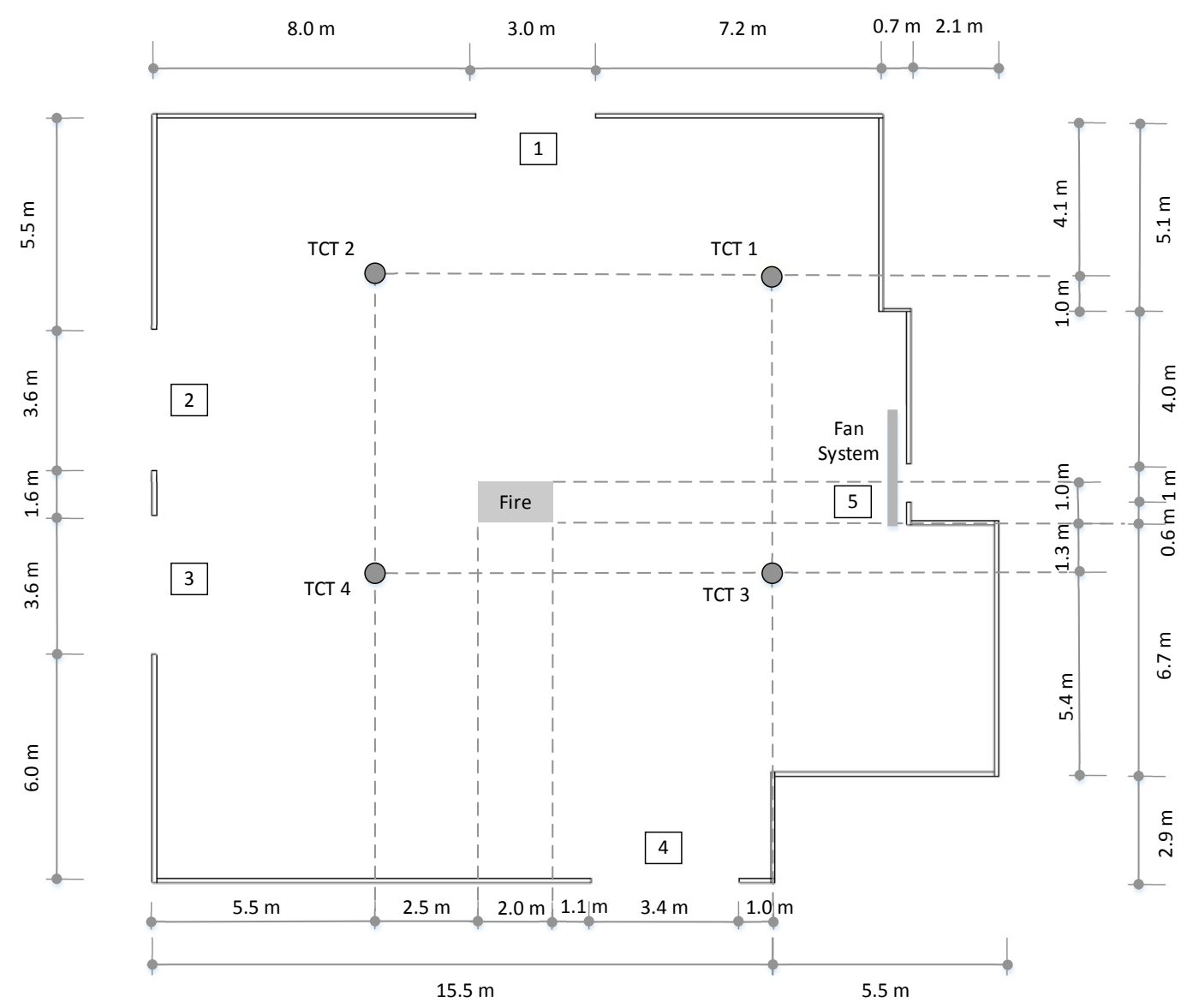

Figure 6-3 Atrium geometry 


\subsection{Full Scale Tests}

Forty-five full-scale atrium fire tests were conducted in Carleton University's full-scale atrium facility to investigate the impact of opening arrangements on the smoke conditions. The make-up air velocity was monitored by the air velocity measuring devices during the test. National Instruments data acquisition system and LabVIEW (National Instruments, 2012) software were used to record the test data. Figure 6-4 shows a photo of a fire test in the atrium.

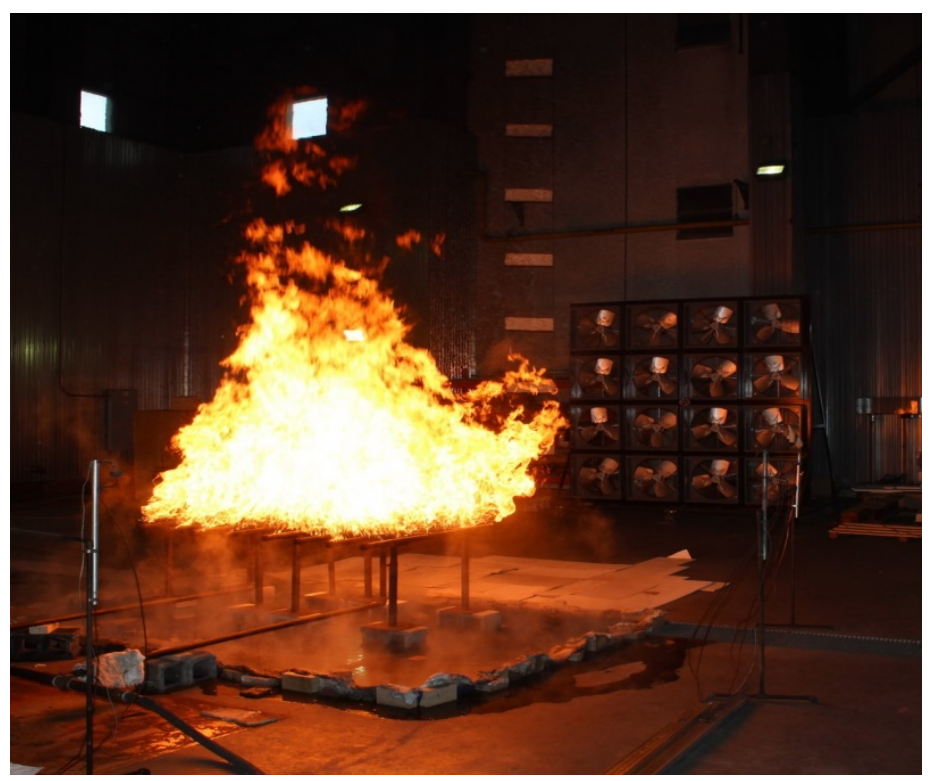

Figure 6-4 Atrium fire test

The fire tests were run as a series of tests, where each new test commenced right after the steady conditions of the previous test. The transition period continued about $100 \mathrm{sec}$ between the tests. For the first and second tests in which the openings were located on 
four sides and two-opposite sides a duct/fan system was used to simulate one of the openings on one side of the atrium. The duct/fan system was constructed using sixteen fans which were assembled in groups of four. To control the air velocity, different number of fans was activated.

The air velocity was monitored at several locations in the atrium to ensure that the fresh air velocity was at the required velocity before starting the fire. Propane was used as the fuel for the tests and the mass flow rate was adjusted to provide the heat release rate which was planned for the test.

The ambient temperature was updated during the calculations for each step, as it increased during the test due to the effect of the fire and radiation from the hot layer to the cold lower layer.

The average temperature profile along the atrium height was plotted for the $200 \mathrm{sec}$ of each steady state condition and the smoke layer height was deduced based on the NPercentage method with $\mathrm{N}$ value corresponding to 0.2 . In order to increase the accuracy of this method, linear interpolation was used to calculate the smoke layer height to two decimal places for the values between the recorded temperatures from the experiment.

For instance, if the thermocouple at $6 \mathrm{~m}$ recorded a temperature of $4^{\circ} \mathrm{C}$ and the thermocouple at $7 \mathrm{~m}$ recorded a temperature of $6^{\circ} \mathrm{C}$, the estimated temperature by the N-Percentage method corresponding to the height of the first indication of smoke would 
be $5^{\circ} \mathrm{C}$. By linear interpolation of these numbers, the smoke layer height corresponding to $5^{\circ} \mathrm{C}$ is $6.50 \mathrm{~m}$.

Tests were conducted for fire sizes of 1, 2.5 and $5 \mathrm{MW}$. For each fire size the effect of opening arrangement on the smoke condition in the atrium was investigated for $1,1.5$ and $2 \mathrm{~m} / \mathrm{s}$ air velocity.

\subsection{MW Fire:}

The fire tests were conducted by first turning on the smoke management system for 10 minutes before starting the fire in order to reach stable airflow conditions in the atrium. The exhaust system was set at $33 \mathrm{~m}^{3} / \mathrm{s}$. With this exhaust flow rate the correlations estimation for the smoke interface height was $12.93 \mathrm{~m}$ from the atrium floor.

Ambient temperature was recorded at $0^{\circ} \mathrm{C}$ before starting the tests for the $1 \mathrm{~m} / \mathrm{s}$ air velocity test and recorded at $1{ }^{\circ} \mathrm{C}$ for the 1.5 and $2 \mathrm{~m} / \mathrm{s}$ air velocity tests. The smoke conditions in the atrium reached steady state $500 \mathrm{sec}$ after starting the fire in the atrium. Table 6-1 shows the time duration and opening conditions for the $1 \mathrm{MW}$ atrium fire tests. 
Table 6-1 Test characteristics for the $1 \mathrm{MW}$ fire exposed to different opening arrangement

\begin{tabular}{|c|c|c|c|c|c|c|c|}
\hline \multirow{3}{*}{$\begin{array}{l}\text { Make-up air } \\
\text { velocity } \\
(\mathrm{m} / \mathrm{s})\end{array}$} & \multirow[t]{3}{*}{$\begin{array}{l}\text { Opening } \\
\text { arrangement }\end{array}$} & \multirow{3}{*}{$\begin{array}{l}\text { Time } \\
\text { duration } \\
\text { (Sec) }\end{array}$} & \multicolumn{3}{|c|}{ Opening conditions } & \multicolumn{2}{|c|}{$\begin{array}{l}\text { Width }(m) \\
\text { Height }(m)\end{array}$} \\
\hline & & & \multirow[t]{2}{*}{1} & \multirow[t]{2}{*}{2} & \multirow[t]{2}{*}{3} & \multirow[t]{2}{*}{4} & 5 \\
\hline & & & & & & & Fan \\
\hline \multirow{10}{*}{1} & \multirow{2}{*}{4 sides } & \multirow{2}{*}{$500-1250$} & 3.00 & 3.60 & 3.60 & 3.40 & \multirow{2}{*}{ on } \\
\hline & & & 2.75 & 1.14 & 1.14 & 2.43 & \\
\hline & \multirow{2}{*}{$\begin{array}{l}\text { 2-opposite } \\
\text { sides }\end{array}$} & \multirow{2}{*}{$1350-2050$} & \multirow{2}{*}{ - } & 3.60 & 3.60 & \multirow{2}{*}{ - } & \multirow{2}{*}{ on } \\
\hline & & & & 2.30 & 2.30 & & \\
\hline & \multirow{2}{*}{$\begin{array}{l}\text { 2-adjacent } \\
\text { sides }\end{array}$} & \multirow{2}{*}{$2150-2800$} & \multirow{2}{*}{-} & 3.60 & 3.60 & 3.40 & \multirow{2}{*}{ off } \\
\hline & & & & 2.30 & 2.30 & 4.85 & \\
\hline & \multirow{2}{*}{3 sides } & \multirow{2}{*}{$2900-3650$} & 3.00 & 3.60 & 3.60 & 3.40 & \multirow{2}{*}{ off } \\
\hline & & & 3.67 & 1.53 & 1.53 & 3.23 & \\
\hline & \multirow{2}{*}{1 side } & \multirow{2}{*}{$3750-4500$} & \multirow{2}{*}{-} & 3.60 & 3.60 & & \multirow{2}{*}{ off } \\
\hline & & & & 4.58 & 4.58 & 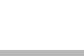 & \\
\hline & 4 sides & $500-1250$ & 3.00 & 3.60 & 3.60 & 3.40 & $0 n$ \\
\hline & 4 sines & 500 & 1.83 & 0.76 & 0.76 & 1.62 & Uiा \\
\hline & 2-opposite & $1350-2050$ & - & 3.60 & 3.60 & - & $0 n$ \\
\hline & sides & טos & 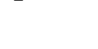 & 1.53 & 1.53 & 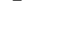 & Uiा \\
\hline 1.5 & 2-adjacent & $2150-2850$ & - & 3.60 & 3.60 & 3.40 & fff \\
\hline 1.0 & sides & $2+30=2000$ & - & 1.53 & 1.53 & 3.23 & 011 \\
\hline & 3 sides & $2950-3650$ & 3.00 & 3.60 & 3.60 & 3.40 & off \\
\hline & & $2950-5050$ & 2.45 & 1.02 & 1.02 & 2.15 & 011 \\
\hline & 1 side & $3750-4500$ & - & 3.60 & 3.60 & - & off \\
\hline & & $3 / 50-4500$ & - & 3.05 & 3.05 & - & 011 \\
\hline & 4 sides & $500-1200$ & 3.00 & 3.60 & 3.60 & 3.40 & on \\
\hline & 4 siaes & $300-1200$ & 1.37 & 0.57 & 0.57 & 1.21 & on \\
\hline & 2-opposite & $1400-2050$ & - & 3.60 & 3.60 & & $n$ \\
\hline & sides & $1400-\angle 050$ & 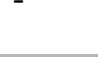 & 1.15 & 1.15 & - & Uiा \\
\hline 2 & 2-adjacent & $2150-2850$ & - & 3.60 & 3.60 & 3.40 & off \\
\hline & sides & & - & 1.15 & 1.15 & 2.42 & 011 \\
\hline & 3 sides & $3000-3650$ & 3.00 & 3.60 & 3.60 & 3.40 & off \\
\hline & & & 1.83 & 0.76 & 0.76 & 1.61 & $0 \pi$ \\
\hline & 1 side & $3800-4500$ & - & 3.60 & 3.60 & - & off \\
\hline & & & & 2.29 & 2.29 & & \\
\hline
\end{tabular}


The temperature profiles along the height of the atrium are shown in Figures 6-5 to 6-7. As the beginning of the transition part of the temperature profile represents the first indication of smoke layer, the decrease in smoke layer height by changing the opening arrangement from 2-opposite side opening to 2-adjacent side opening is larger than the decrease in changing to the other opening arrangements. Moreover, in the temperature profile of $2 \mathrm{~m} / \mathrm{s}$ air velocity test, the growing thickness of the transition zone from the cold layer temperature to the hot layer shows the effect of increased turbulence due to the higher make-up air velocity and opening arrangement.

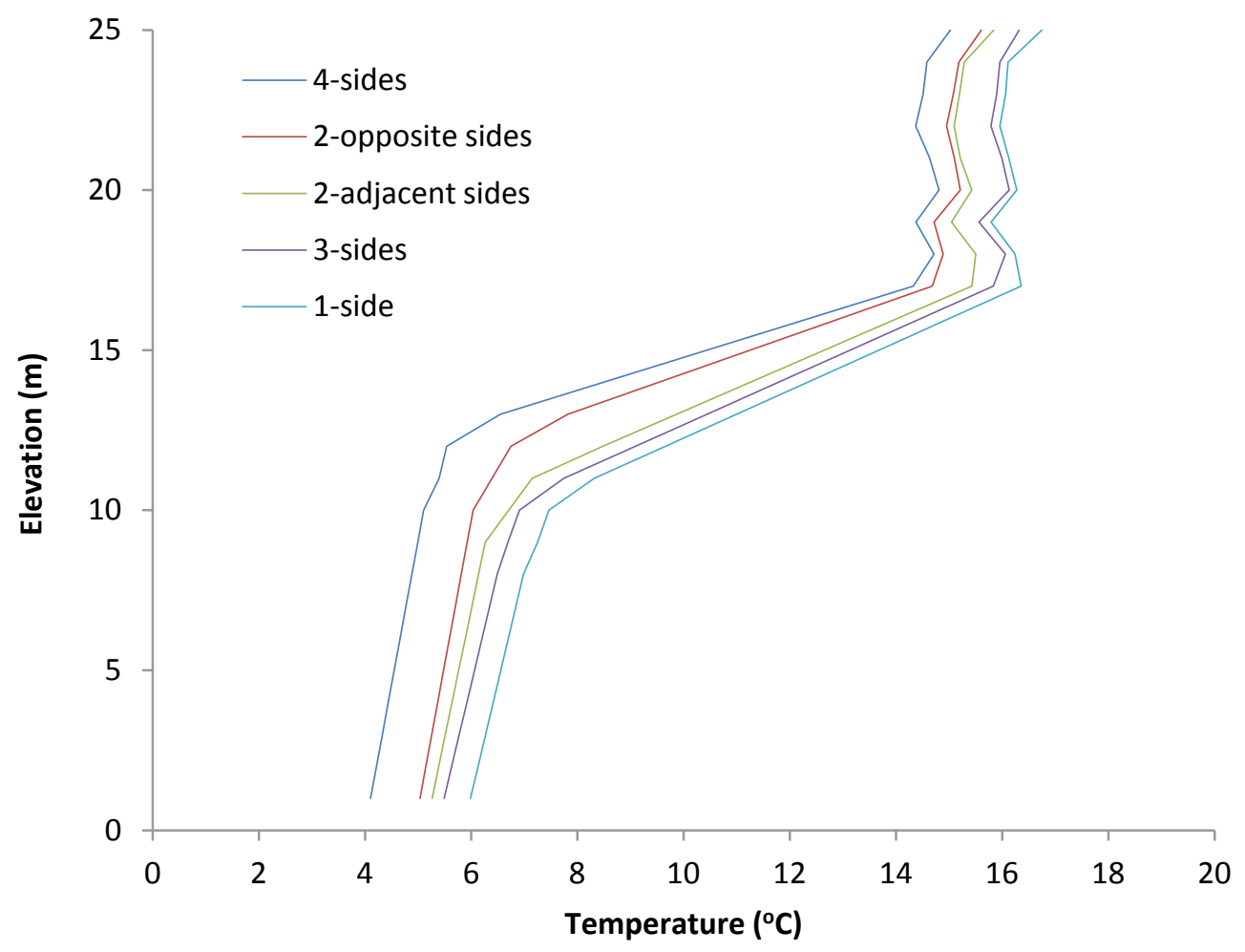

Figure 6-5 Vertical temperature profile for the $1 \mathrm{MW}$ fire test exposed to $1 \mathrm{~m} / \mathrm{s}$ air velocity 


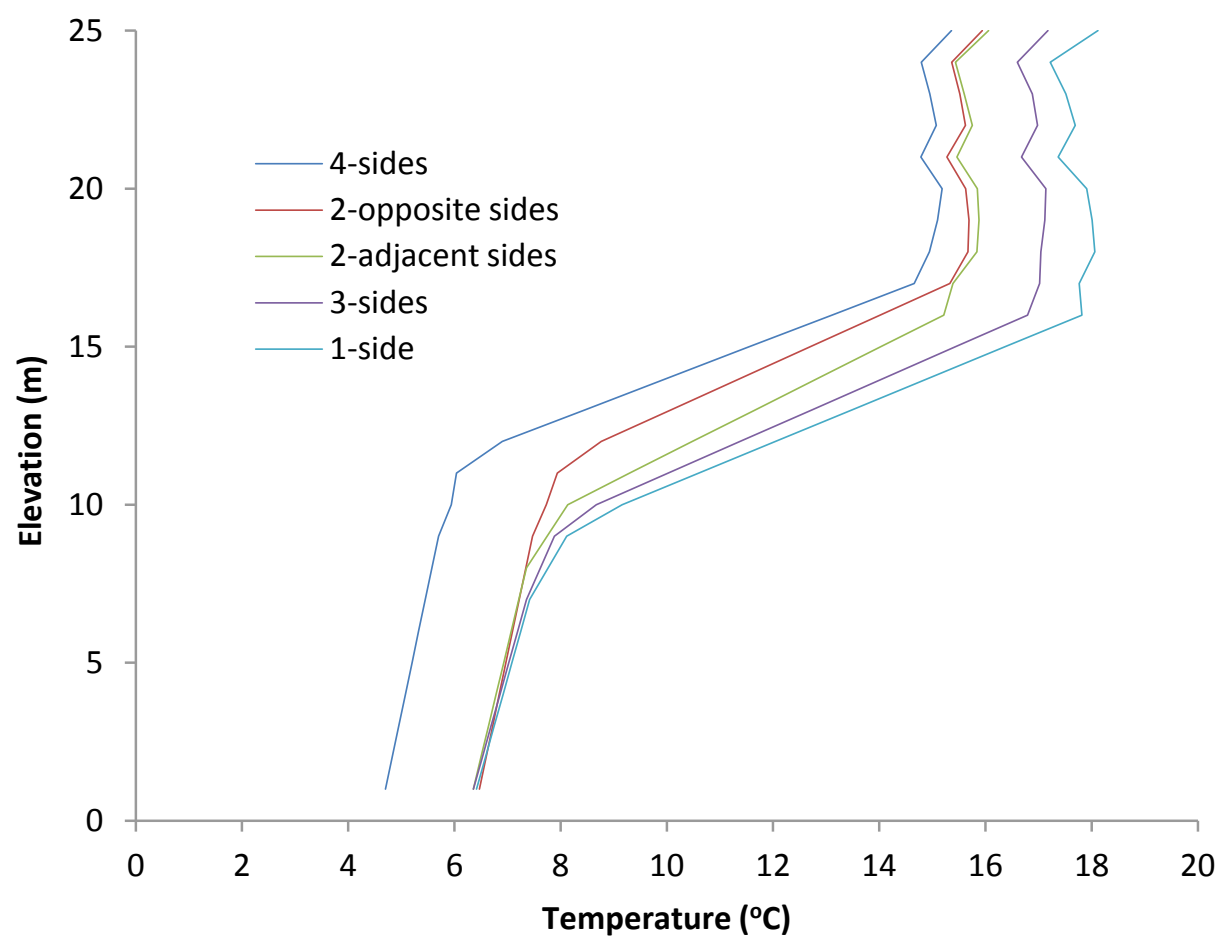

Figure 6-6 Vertical temperature profile for the $1 \mathrm{MW}$ fire test exposed to $1.5 \mathrm{~m} / \mathrm{s}$ air velocity

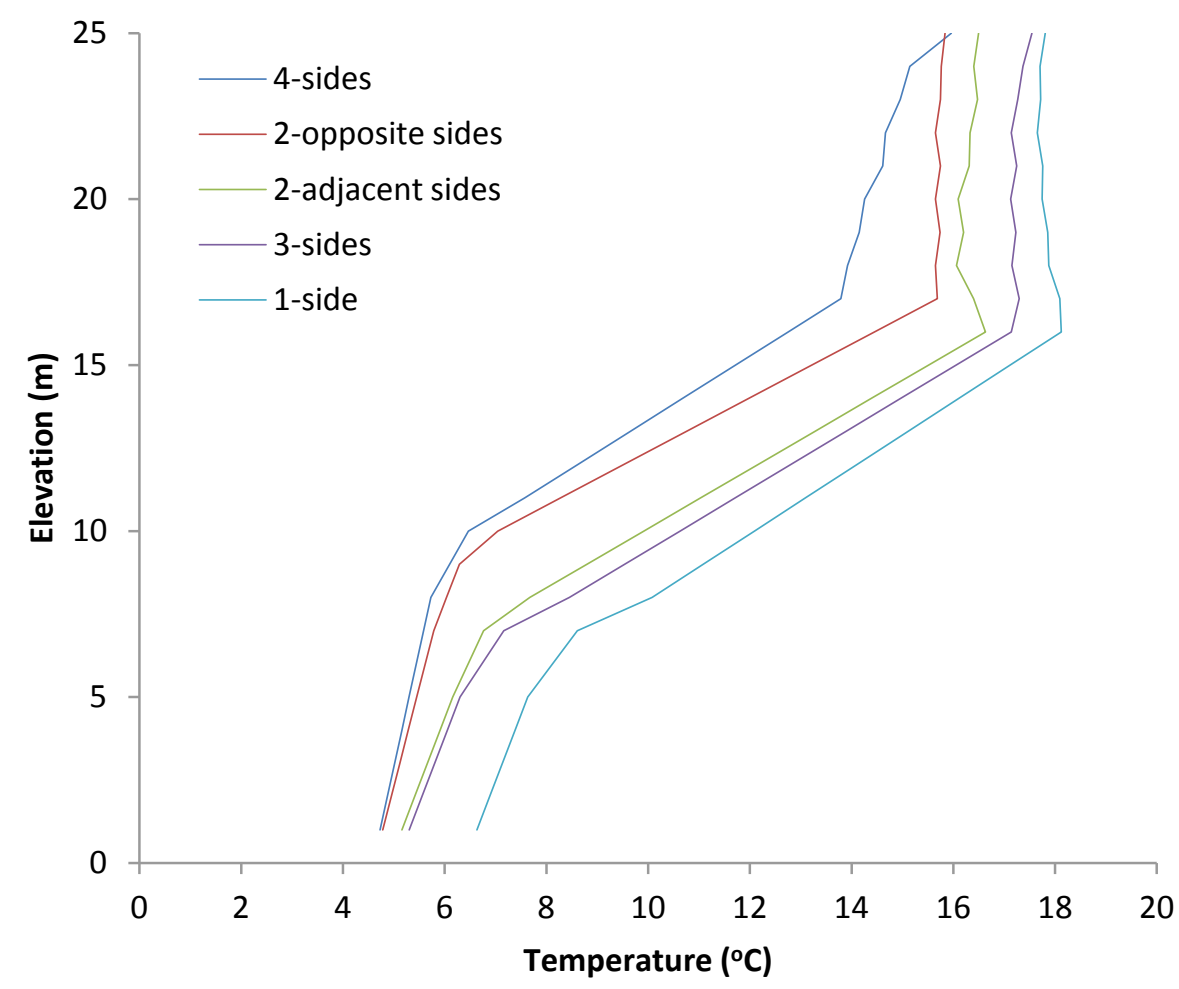

Figure 6-7 Vertical temperature profile for the $1 \mathrm{MW}$ fire test exposed to $2 \mathrm{~m} / \mathrm{s}$ air velocity 


\subsubsection{Discussion of Experimental Results}

The smoke layer height from the experimental data is listed in Table 6-2 and plotted in Figure 6-8. As the normalized values show, the smoke layer height decreases with changing the opening arrangement from 4-sides to 1-side opening and the smoke layer height decreases increases with increasing the make-up air velocity. The normalized value decreases to 0.68 for the 1 -side opening in $2 \mathrm{~m} / \mathrm{s}$ air velocity test while it is 0.84 for the same test in the $1 \mathrm{~m} / \mathrm{s}$ air velocity. In addition, the graph shows that the decrease in smoke layer height is larger when the opening arrangement changes from 2-opposite side openings to 2 -adjacent side openings. 
Table 6-2 Smoke Layer height in the $1 \mathrm{MW}$ fire test exposed to different opening arrangement

\begin{tabular}{|c|c|c|c|c|}
\hline \multicolumn{5}{|c|}{ Smoke layer height from Experiment } \\
\hline $\begin{array}{l}\text { Make-up air } \\
\text { velocity }\end{array}$ & $\begin{array}{l}\text { Opening } \\
\text { arrangement }\end{array}$ & $\begin{array}{l}\text { Visual } \\
\text { observation } \\
\text { (m) }\end{array}$ & $\begin{array}{l}\text { N-Percentage } \\
\text { Method } \\
\text { (m) }\end{array}$ & Normalized Value \\
\hline \multirow{5}{*}{$1 \mathrm{~m} / \mathrm{s}$} & Four sides & 13 & 12.75 & 1 \\
\hline & $\begin{array}{l}\text { Two-opposite } \\
\text { sides }\end{array}$ & 12.5 & 12.37 & 0.97 \\
\hline & $\begin{array}{l}\text { Two-adjacent } \\
\text { sides }\end{array}$ & 11 & 11.17 & 0.87 \\
\hline & Three sides & 11 & 10.89 & 0.85 \\
\hline & One side & 10.5 & 10.78 & 0.84 \\
\hline \multirow{5}{*}{$1.5 \mathrm{~m} / \mathrm{s}$} & Four sides & 12 & 11.91 & 1 \\
\hline & $\begin{array}{l}\text { Two-opposite } \\
\text { sides }\end{array}$ & 11.5 & 11.51 & 0.96 \\
\hline & $\begin{array}{l}\text { Two-adjacent } \\
\text { sides }\end{array}$ & 10 & 10.14 & 0.85 \\
\hline & Three sides & 10 & 9.80 & 0.82 \\
\hline & One side & 9.5 & 9.61 & 0.80 \\
\hline \multirow{5}{*}{$2 \mathrm{~m} / \mathrm{s}$} & Four sides & 10.5 & 10.45 & 1 \\
\hline & $\begin{array}{l}\text { Two-opposite } \\
\text { sides }\end{array}$ & 10 & 9.93 & 0.95 \\
\hline & $\begin{array}{l}\text { Two-adjacent } \\
\text { sides }\end{array}$ & 7.5 & 7.72 & 0.73 \\
\hline & Three sides & 7.5 & 7.45 & 0.71 \\
\hline & One side & 7 & 7.17 & 0.68 \\
\hline
\end{tabular}




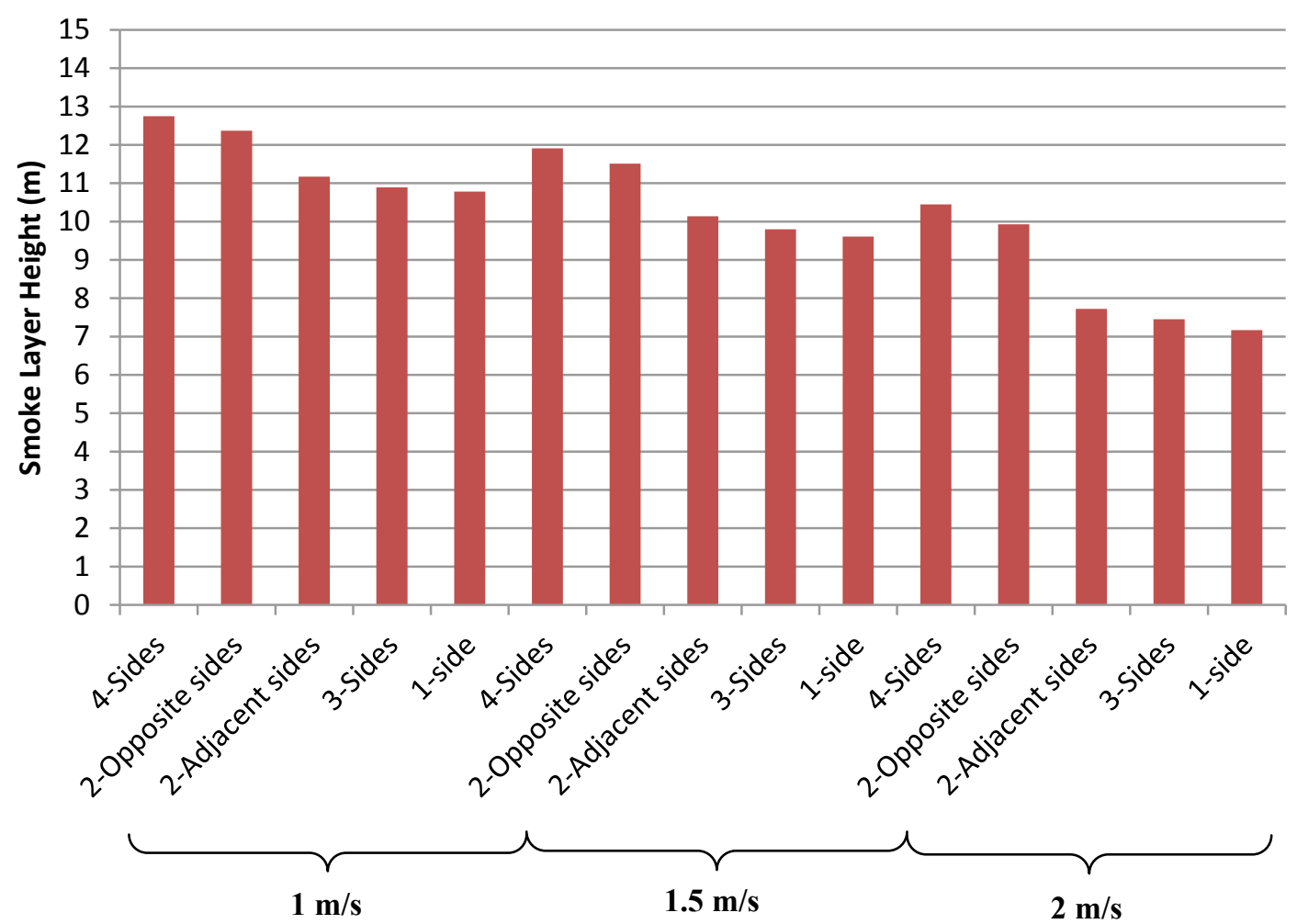

Figure 6-8 Smoke Layer height in the $1 \mathrm{MW}$ fire test exposed to different opening arrangement 


\subsubsection{MW Fire Test Simulation}

The tests discussed in the previous section have been simulated using FDS5. The simulations considered the effect of the five different opening arrangements in the atrium. Instead of the fan system which was used in the atrium tests, an appropriate opening has been located on each side as required. The openings have been located at the center of the atrium sides. All other conditions such as exhaust rate and ambient temperature have been modeled to be the same as the test conditions. A mesh size of $0.26 \times 0.26 \times 0.26 \mathrm{~m}$ was applied to the entire computational domain. The model was run for $600 \mathrm{sec}$ for each test separately to ensure steady state conditions were reached.

Table 6-3 shows the average smoke layer height from the simulation predictions at different points of the last $200 \mathrm{sec}$ of each atrium fire test. The normalized values of the smoke layer height are also listed in this table. Figure 6-9 shows the smoke layer height from the simulation results. Based on this figure, locating openings on two-adjacent sides, three-sides and one-side of the atrium cause a drop in the smoke interface height. The difference between the smoke layer height for the 4-side and two-opposite side tests is very small, demonstrating that symmetrical opening arrangements are the most effective. 
Table 6-3 Smoke layer height from CFD modelling of the $1 \mathrm{MW}$ fire test exposed to different opening arrangement

\begin{tabular}{|c|c|c|c|c|}
\hline \multicolumn{5}{|c|}{ Smoke layer height from CFD Modelling } \\
\hline $\begin{array}{l}\text { Make-up air } \\
\text { velocity }\end{array}$ & $\begin{array}{l}\text { Opening } \\
\text { arrangement }\end{array}$ & $\begin{array}{l}\text { Design } \\
\text { (m) }\end{array}$ & $\begin{array}{l}\text { CFD Modeling } \\
\text { (m) }\end{array}$ & $\begin{array}{l}\text { Normalized } \\
\text { Value }\end{array}$ \\
\hline \multirow{5}{*}{$1 \mathrm{~m} / \mathrm{s}$} & Four sides & 12.93 & 10.91 & 1 \\
\hline & $\begin{array}{l}\text { Two-opposite } \\
\text { sides }\end{array}$ & 12.93 & 10.43 & 0.95 \\
\hline & $\begin{array}{l}\text { Two-adjacent } \\
\text { sides }\end{array}$ & 12.93 & 9.47 & 0.86 \\
\hline & Three sides & 12.93 & 9.12 & 0.83 \\
\hline & One side & 12.93 & 9.24 & 0.84 \\
\hline \multirow{5}{*}{$1.5 \mathrm{~m} / \mathrm{s}$} & Four sides & 12.93 & 10.41 & 1 \\
\hline & $\begin{array}{l}\text { Two-opposite } \\
\text { sides }\end{array}$ & 12.93 & 9.81 & 0.94 \\
\hline & $\begin{array}{l}\text { Two-adjacent } \\
\text { sides }\end{array}$ & 12.93 & 8.61 & 0.82 \\
\hline & Three sides & 12.93 & 8.24 & 0.79 \\
\hline & One side & 12.93 & 8.41 & 0.80 \\
\hline \multirow{5}{*}{$2 \mathrm{~m} / \mathrm{s}$} & Four sides & 12.93 & 9.21 & 1 \\
\hline & $\begin{array}{l}\text { Two-opposite } \\
\text { sides }\end{array}$ & 12.93 & 8.56 & 0.93 \\
\hline & $\begin{array}{l}\text { Two-adjacent } \\
\text { sides }\end{array}$ & 12.93 & 6.88 & 0.74 \\
\hline & Three sides & 12.93 & 6.35 & 0.68 \\
\hline & One side & 12.93 & 6.48 & 0.70 \\
\hline
\end{tabular}




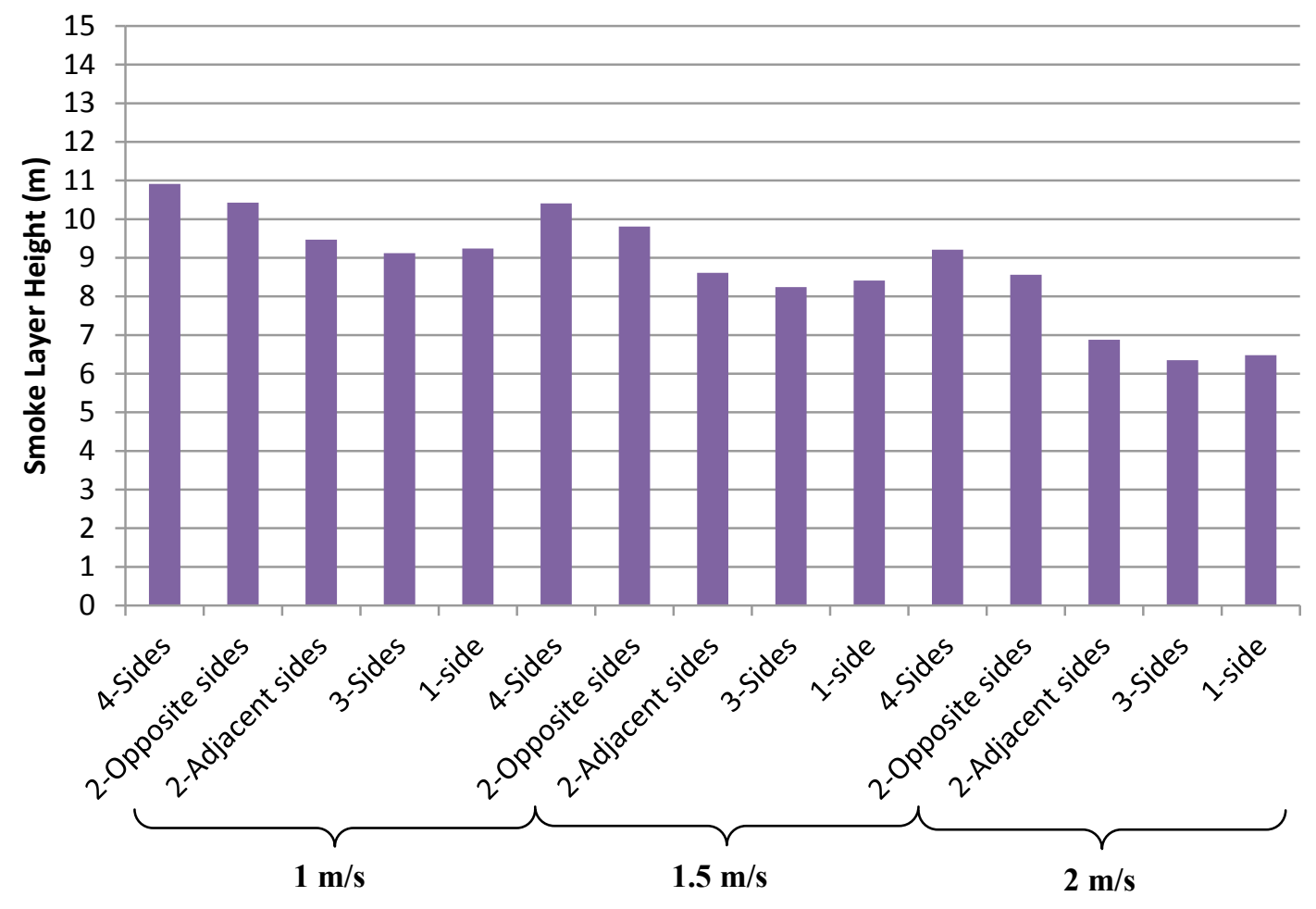

Figure 6-9 Smoke layer height from CFD modelling of the $1 \mathrm{MW}$ fire test exposed to different opening arrangement 


\subsection{MW Fire Test}

In this series of tests, the effect of opening arrangement on the smoke layer height with 1, 1.5 and $2 \mathrm{~m} / \mathrm{s}$ make-up air velocities and a $2 \mathrm{MW}$ fire has been investigated. At the beginning of each series of tests, the smoke management system has been allowed to run at $33 \mathrm{~m}^{3} / \mathrm{sec}$ for $10 \mathrm{~min}$ to reach the steady state conditions in the air circulation in the atrium before starting the fire. The atrium correlations estimate the smoke layer height to decrease to $11.2 \mathrm{~m}$ from the floor. The ambient temperature was measured at $2^{\circ} \mathrm{C}$ before starting the fire for $1 \mathrm{~m} / \mathrm{s}$ air velocity test and was measured at $1^{\circ} \mathrm{C}$ for 1.5 and $2 \mathrm{~m} / \mathrm{s}$ air velocity tests. The smoke conditions in the atrium reached steady state after $500 \mathrm{sec}$ after starting the fire in each case. Table 6-4 shows the time duration and opening arrangements for the $2 \mathrm{MW}$ fire tests. 
Table 6-4 Test characteristics for the 2 MW fire exposed to different opening arrangement

\begin{tabular}{|c|c|c|c|c|c|c|c|}
\hline \multirow{3}{*}{$\begin{array}{l}\text { Make-up air } \\
\text { velocity } \\
(\mathrm{m} / \mathrm{s})\end{array}$} & \multirow[t]{3}{*}{$\begin{array}{l}\text { Opening } \\
\text { arrangement }\end{array}$} & \multirow{3}{*}{$\begin{array}{l}\text { Time } \\
\text { duration } \\
\text { (Sec) }\end{array}$} & \multicolumn{3}{|c|}{ Opening conditions } & \multicolumn{2}{|c|}{$\begin{array}{l}\text { Width (m) } \\
\text { Height (m) }\end{array}$} \\
\hline & & & \multirow[t]{2}{*}{1} & \multirow[t]{2}{*}{2} & \multirow[t]{2}{*}{3} & \multirow[t]{2}{*}{4} & 5 \\
\hline & & & & & & & Fan \\
\hline \multirow{10}{*}{1} & \multirow{2}{*}{4 sides } & \multirow{2}{*}{$500-1350$} & 3.00 & 3.60 & 3.60 & 3.40 & \multirow{2}{*}{ on } \\
\hline & & & 2.75 & 1.14 & 1.14 & 2.43 & \\
\hline & \multirow{2}{*}{$\begin{array}{l}\text { 2-opposite } \\
\text { sides }\end{array}$} & \multirow{2}{*}{$1450-2150$} & \multirow{2}{*}{-} & 3.60 & 3.60 & \multirow{2}{*}{-} & \multirow{2}{*}{ on } \\
\hline & & & & 2.30 & 2.30 & & \\
\hline & \multirow{2}{*}{$\begin{array}{l}\text { 2-adjacent } \\
\text { sides }\end{array}$} & \multirow{2}{*}{$2250-2950$} & \multirow{2}{*}{ - } & 3.60 & 3.60 & 3.40 & \multirow{2}{*}{ off } \\
\hline & & & & 2.30 & 2.30 & 4.85 & \\
\hline & \multirow{2}{*}{3 sides } & \multirow{2}{*}{$3050-3750$} & 3.00 & 3.60 & 3.60 & 3.40 & \multirow{2}{*}{ off } \\
\hline & & & 3.67 & 1.53 & 1.53 & 3.23 & \\
\hline & \multirow{2}{*}{1 side } & \multirow{2}{*}{$3850-4500$} & \multirow{2}{*}{-} & 3.60 & 3.60 & \multirow{2}{*}{-} & off \\
\hline & & & & 4.58 & 4.58 & & Uiा \\
\hline & A cidec & $500-1350$ & 3.00 & 3.60 & 3.60 & 3.40 & $a n$ \\
\hline & 4 sines & טכנד & 1.83 & 0.76 & 0.76 & 1.62 & OII \\
\hline & 2-opposite & $1450-2050$ & - & 3.60 & 3.60 & 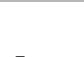 & 0 s \\
\hline & sides & $1450-2030$ & - & 1.53 & 1.53 & - & OII \\
\hline 15 & 2-adjacent & $2150-2850$ & - & 3.60 & 3.60 & 3.40 & off \\
\hline 1.0 & sides & $2130-2030$ & - & 1.53 & 1.53 & 3.23 & 011 \\
\hline & 3 sides & $2950-3650$ & 3.00 & 3.60 & 3.60 & 3.40 & off \\
\hline & & $2950-3050$ & 2.45 & 1.02 & 1.02 & 2.15 & \\
\hline & 1 side & $3750-4400$ & - & 3.60 & 3.60 & - & off \\
\hline & & $3 / 30-4400$ & & 3.05 & 3.05 & - & \\
\hline & 4 sides & $500-1150$ & 3.00 & 3.60 & 3.60 & 3.40 & on \\
\hline & 4 sides & $500-1150$ & 1.37 & 0.57 & 0.57 & 1.21 & on \\
\hline & 2-opposite & $1300-1850$ & - & 3.60 & 3.60 & - & $a n$ \\
\hline & sides & $1300-1030$ & - & 1.15 & 1.15 & - & $0 \pi$ \\
\hline 2 & 2-adjacent & $1950-2550$ & - & 3.60 & 3.60 & 3.40 & off \\
\hline & sides & & - & 1.15 & 1.15 & 2.42 & $0 \pi 11$ \\
\hline & 3 sides & $2650-3250$ & 3.00 & 3.60 & 3.60 & 3.40 & off \\
\hline & & & 1.83 & 0.76 & 0.76 & 1.61 & 011 \\
\hline & 1 side & $3350-4200$ & - & 3.60 & 3.60 & - & off \\
\hline & & & & 2.29 & 2.29 & - & \\
\hline
\end{tabular}


The average temperature profiles over a $200 \mathrm{sec}$ period of each steady condition along the atrium height are shown in Figures 6-10 to 6-12. As this figure shows, the temperature profiles change with changing the opening arrangements. A comparison of the temperature profiles for the $1 \mathrm{~m} / \mathrm{s}$ and $1.5 \mathrm{~m} / \mathrm{s}$ air velocity tests show that the changes in temperature profiles of the $2 \mathrm{~m} / \mathrm{s}$ air velocity tests are larger than the changes between the 1 and $1.5 \mathrm{~m} / \mathrm{s}$ air velocity tests.

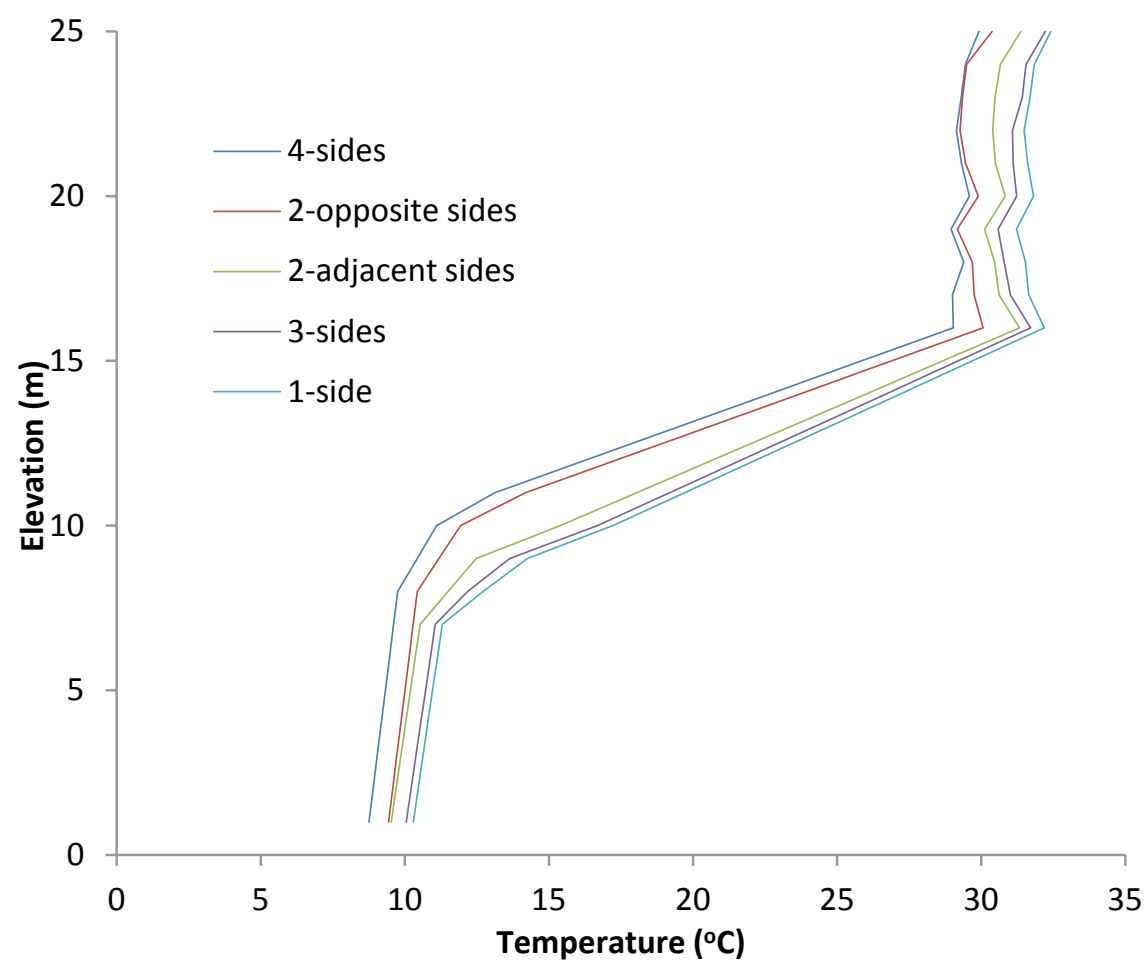

Figure 6-10 Vertical temperature profile for the $2 \mathrm{MW}$ fire test exposed to $1 \mathrm{~m} / \mathrm{s}$ air velocity 


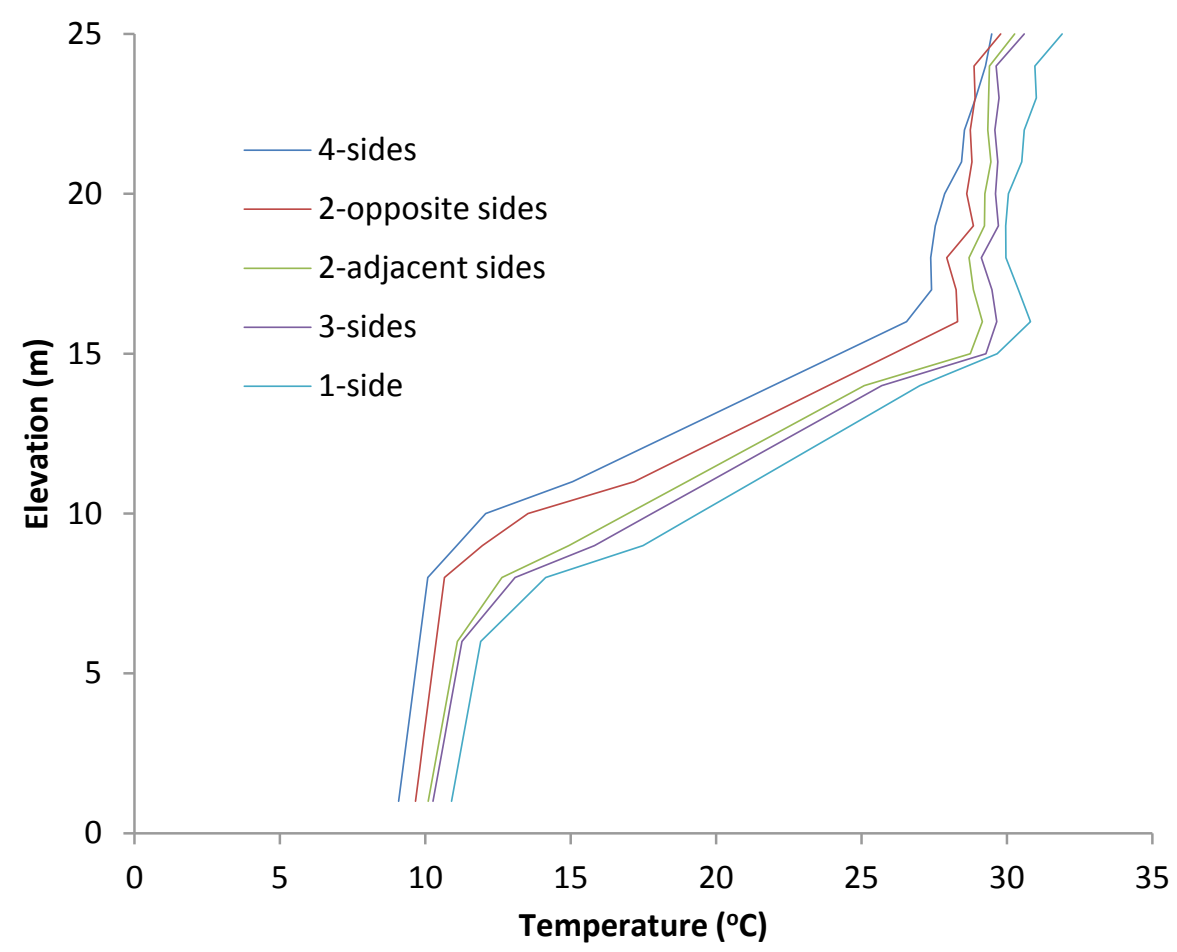

Figure 6-11 Vertical temperature profile for the $2 \mathrm{MW}$ fire test exposed to $1.5 \mathrm{~m} / \mathrm{s}$ air velocity

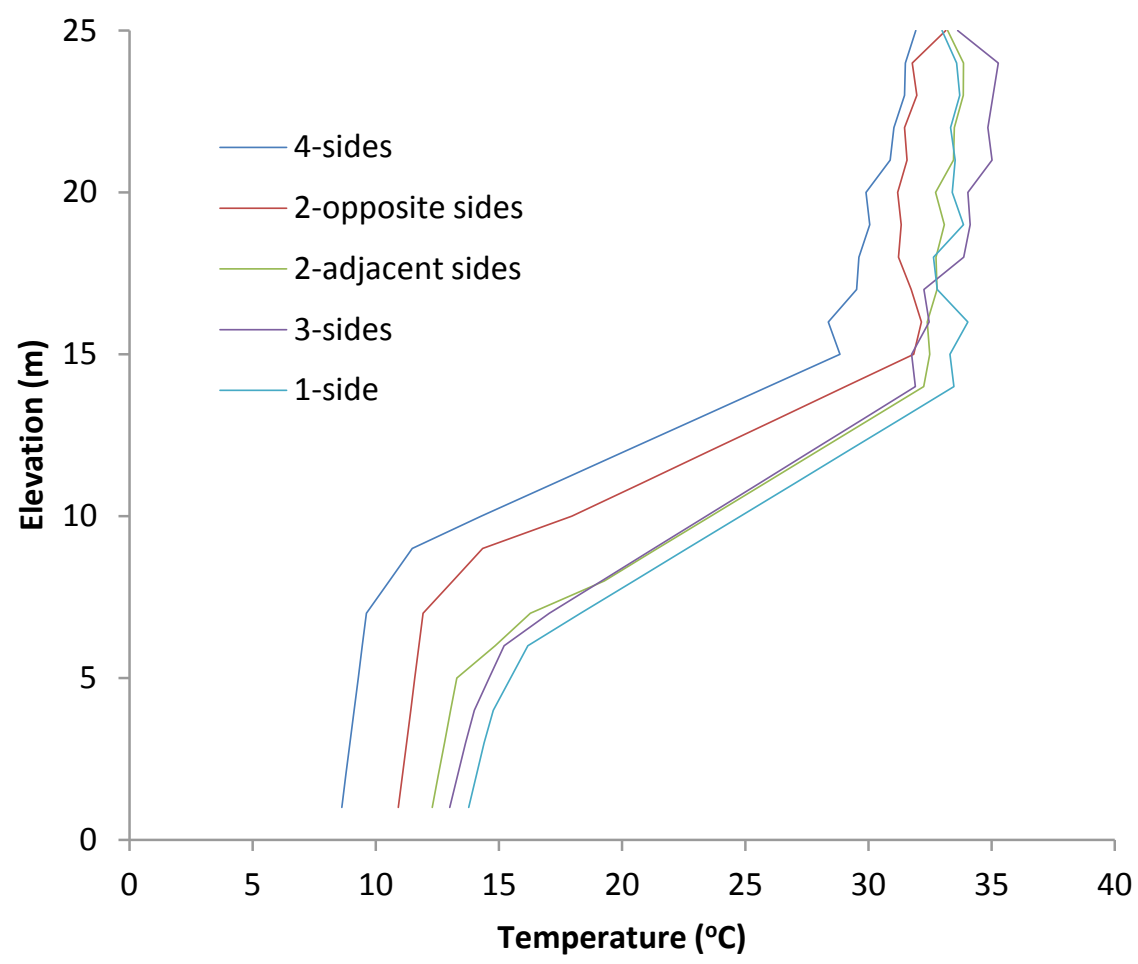

Figure 6-12 Vertical temperature profile for the $2 \mathrm{MW}$ fire test exposed to $2 \mathrm{~m} / \mathrm{s}$ air velocity 


\subsubsection{Discussion of Experimental Results}

Table 6-5 lists the smoke layer height and the normalized values for the $2 \mathrm{MW}$ fire with different opening arrangements and exposed to $1,1.5$ and $2 \mathrm{~m} / \mathrm{s}$ air velocities. This table shows that the normalized values of the smoke layer height decrease from 0.83 for the 1 $\mathrm{m} / \mathrm{s}$ air velocity test to 0.80 for the $1.5 \mathrm{~m} / \mathrm{s}$ air velocity test and to 0.69 for the $2 \mathrm{~m} / \mathrm{s}$ air velocity test. The normalized values were used to find a correlation to calculate the effect of opening arrangement on the smoke layer height in 2 MW fire. Figure 6-13 shows the changes in smoke layer height with changing opening arrangements and air velocities. Based on this figure, increasing the make-up air velocity causes a decrease of the smoke layer height. 
Table 6-5 Smoke Layer height in the $2 \mathrm{MW}$ fire test exposed to different opening arrangement

\begin{tabular}{|c|c|c|c|c|}
\hline \multicolumn{5}{|c|}{ Smoke layer height from Experiment } \\
\hline $\begin{array}{l}\text { Make-up air } \\
\text { velocity }\end{array}$ & $\begin{array}{l}\text { Opening } \\
\text { arrangement }\end{array}$ & $\begin{array}{l}\text { Visual } \\
\text { observation } \\
\text { (m) }\end{array}$ & $\begin{array}{l}\text { N-Percentage } \\
\text { Method } \\
\text { (m) }\end{array}$ & $\begin{array}{l}\text { Normalized } \\
\text { Value }\end{array}$ \\
\hline \multirow{5}{*}{$1 \mathrm{~m} / \mathrm{s}$} & Four sides & 11 & 10.93 & 1 \\
\hline & $\begin{array}{l}\text { Two-opposite } \\
\text { sides }\end{array}$ & 10.5 & 10.74 & 0.98 \\
\hline & $\begin{array}{l}\text { Two-adjacent } \\
\text { sides }\end{array}$ & 9.5 & 9.48 & 0.86 \\
\hline & Three sides & 9.5 & 9.27 & 0.84 \\
\hline & One side & 9 & 9.15 & 0.83 \\
\hline \multirow{5}{*}{$1.5 \mathrm{~m} / \mathrm{s}$} & Four sides & 10.5 & 10.36 & 1 \\
\hline & $\begin{array}{l}\text { Two-opposite } \\
\text { sides }\end{array}$ & 10 & 10.04 & 0.97 \\
\hline & $\begin{array}{l}\text { Two-adjacent } \\
\text { sides }\end{array}$ & 8.5 & 8.65 & 0.83 \\
\hline & Three sides & 8.5 & 8.45 & 0.81 \\
\hline & One side & 8.5 & 8.28 & 0.80 \\
\hline \multirow{5}{*}{$2 \mathrm{~m} / \mathrm{s}$} & Four sides & 9.5 & 9.64 & 1 \\
\hline & $\begin{array}{l}\text { Two-opposite } \\
\text { sides }\end{array}$ & 9 & 9.28 & 0.96 \\
\hline & $\begin{array}{l}\text { Two-adjacent } \\
\text { sides }\end{array}$ & 7 & 7.06 & 0.73 \\
\hline & Three sides & 7 & 6.83 & 0.70 \\
\hline & One side & 6.5 & 6.67 & 0.69 \\
\hline
\end{tabular}




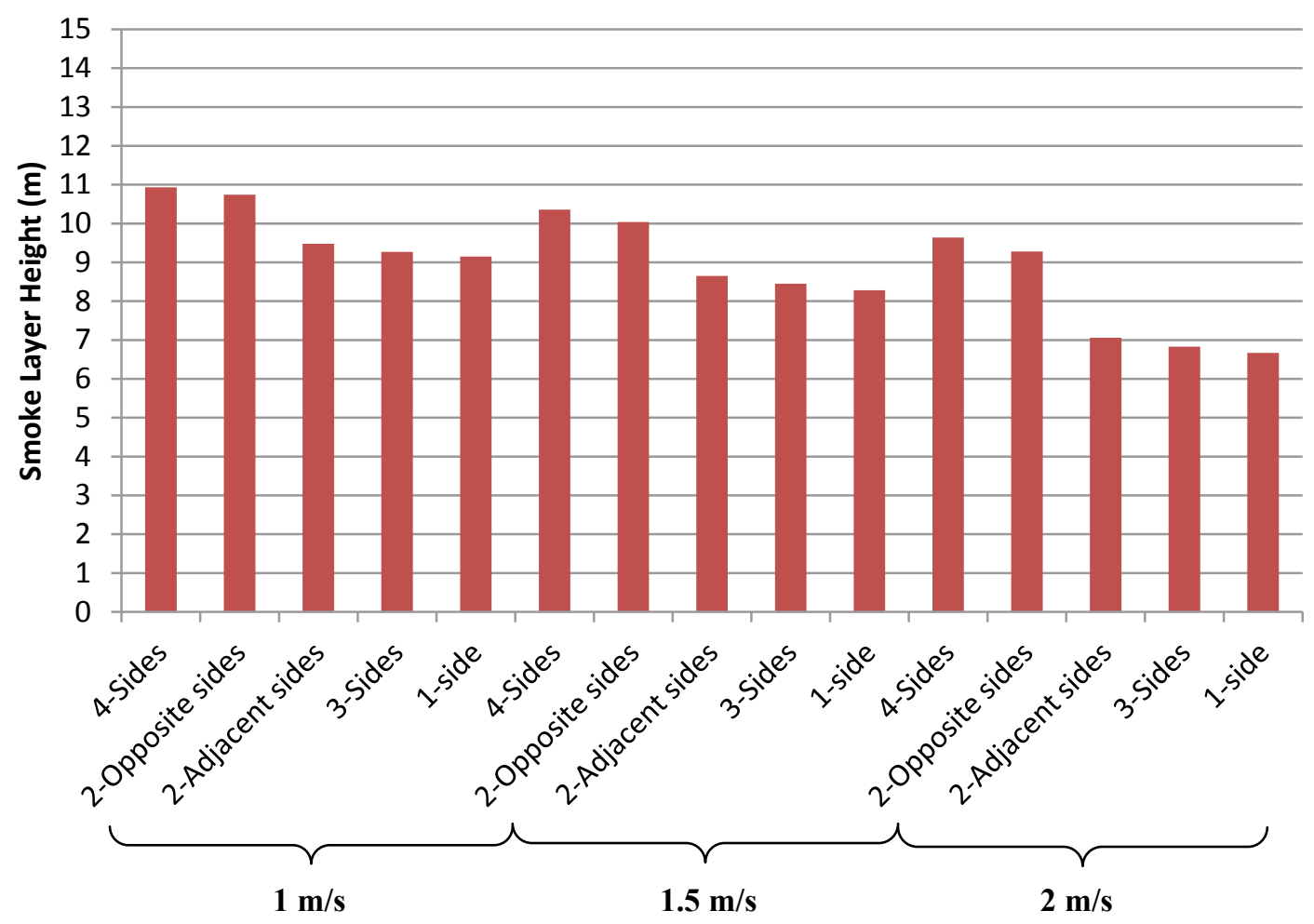

Figure 6-13 Smoke Layer height in the $2 \mathrm{MW}$ fire test exposed to different opening arrangement 


\subsubsection{MW Fire Test Simulation}

The model has been run for $600 \mathrm{sec}$ for each opening arrangement. The last $200 \mathrm{sec}$ of the simulations were used to calculate the smoke layer height. The openings were modeled at the center of atrium walls. The average of the smoke layer heights at different points of the atrium are listed in Table 6-6. Also the smoke layer height is shown in Figure 6-14. This figure shows that the smoke layer decrease is larger when the opening condition changes from 2-opposite side to 2-adjacent side. The difference between 2 -adjacent sides, 3 sides and 1-side opening is very small. Also, the simulation predictions agree that the smoke layer height decreases with increasing the make-up air velocity. 
Table 6-6 Smoke layer height from CFD modelling of the 2 MW fire test exposed to different opening arrangement

\begin{tabular}{|c|c|c|c|c|}
\hline \multicolumn{5}{|c|}{ Smoke layer height from CFD Modelling } \\
\hline $\begin{array}{l}\text { Make-up air } \\
\text { velocity }\end{array}$ & $\begin{array}{l}\text { Opening } \\
\text { arrangement }\end{array}$ & $\begin{array}{l}\text { Design } \\
\text { (m) }\end{array}$ & $\begin{array}{l}\text { CFD Modeling } \\
\text { (m) }\end{array}$ & Normalized Value \\
\hline \multirow{5}{*}{$1 \mathrm{~m} / \mathrm{s}$} & Four sides & 11.2 & 9.51 & 1 \\
\hline & $\begin{array}{l}\text { Two-opposite } \\
\text { sides }\end{array}$ & 11.2 & 9.25 & 0.97 \\
\hline & $\begin{array}{l}\text { Two-adjacent } \\
\text { sides }\end{array}$ & 11.2 & 8.16 & 0.85 \\
\hline & Three sides & 11.2 & 7.84 & 0.82 \\
\hline & One side & 11.2 & 7.91 & 0.83 \\
\hline \multirow{5}{*}{$1.5 \mathrm{~m} / \mathrm{s}$} & Four sides & 11.2 & 9.24 & 1 \\
\hline & $\begin{array}{l}\text { Two-opposite } \\
\text { sides }\end{array}$ & 11.2 & 8.91 & 0.96 \\
\hline & $\begin{array}{l}\text { Two-adjacent } \\
\text { sides }\end{array}$ & 11.2 & 7.51 & 0.81 \\
\hline & Three sides & 11.2 & 7.21 & 0.78 \\
\hline & One side & 11.2 & 7.31 & 0.79 \\
\hline \multirow{5}{*}{$2 \mathrm{~m} / \mathrm{s}$} & Four sides & 11.2 & 8.61 & 1 \\
\hline & $\begin{array}{l}\text { Two-opposite } \\
\text { sides }\end{array}$ & 11.2 & 8.12 & 0.94 \\
\hline & $\begin{array}{l}\text { Two-adjacent } \\
\text { sides }\end{array}$ & 11.2 & 6.61 & 0.76 \\
\hline & Three sides & 11.2 & 6.18 & 0.71 \\
\hline & One side & 11.2 & 6.29 & 0.73 \\
\hline
\end{tabular}




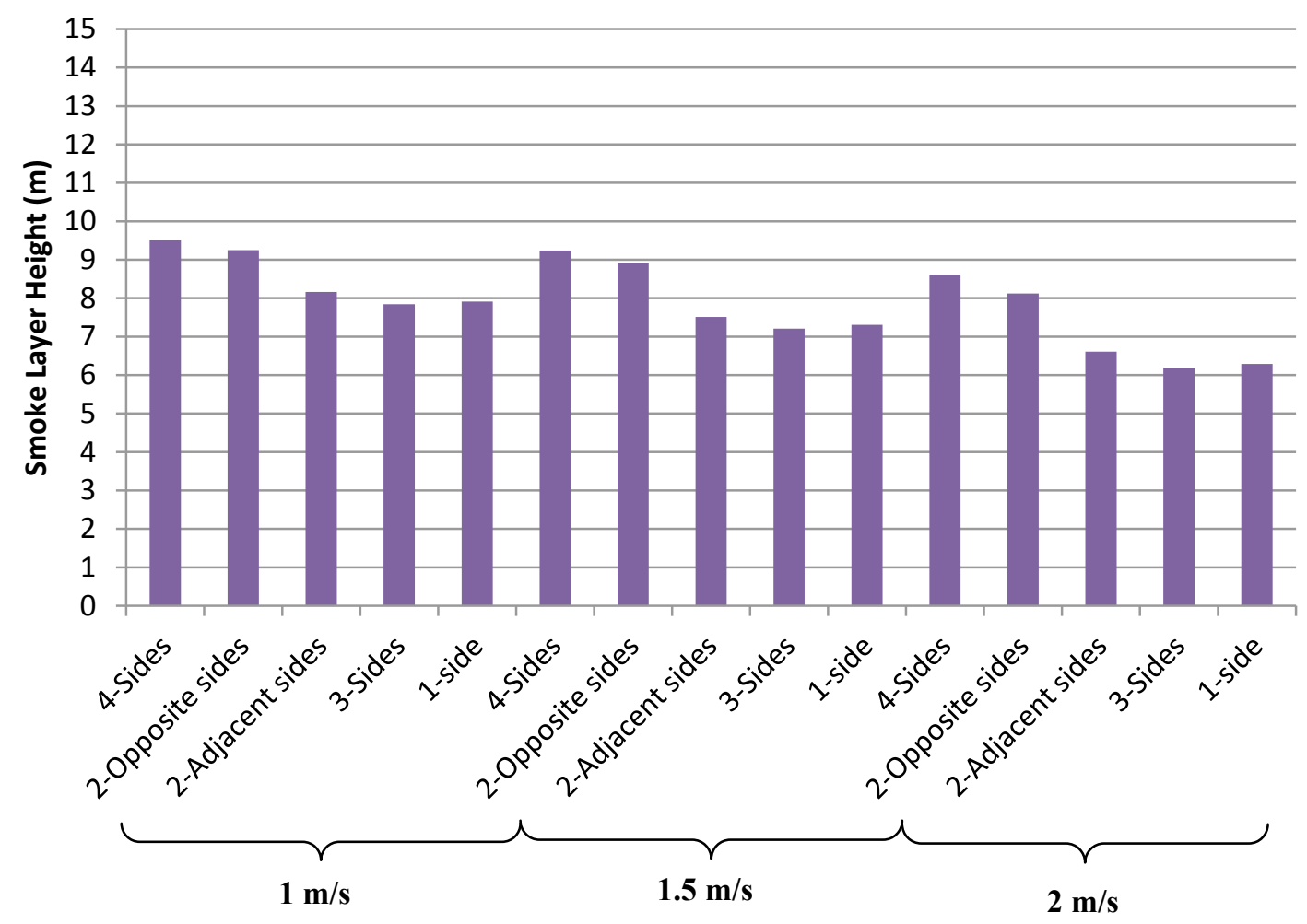

Figure 6-14 Smoke layer height from CFD modelling of the $2 \mathrm{MW}$ fire test exposed to different opening arrangement 


\subsection{MW Fire Test}

Same as for the $1 \mathrm{MW}$ and the $2 \mathrm{MW}$ fire tests, the exhaust system was turned on and allowed to run for $10 \mathrm{~min}$ before starting the $5 \mathrm{MW}$ fire. The exhaust system was set to $33 \mathrm{~m} / \mathrm{s}$ and the make-up air velocity was controlled by changing the opening sizes. Atrium correlations predict the smoke layer height at $9 \mathrm{~m}$ from the floor for this fire size. The ambient temperature was recorded at $-6^{\circ} \mathrm{C}$ before starting the fire for the $1 \mathrm{~m} / \mathrm{s}$ air velocity test, $-8^{\circ} \mathrm{C}$ for the for the $1.5 \mathrm{~m} / \mathrm{s}$ air velocity test and $-5^{\circ} \mathrm{C}$ for the $2 \mathrm{~m} / \mathrm{s}$ air velocity test. The smoke conditions reached the steady state $500 \mathrm{sec}$ after starting the fire for the $1 \mathrm{~m} / \mathrm{s}$ air velocity test, $700 \mathrm{sec}$ after starting the fire for the $1.5 \mathrm{~m} / \mathrm{s}$ air velocity test and $1000 \mathrm{sec}$ after starting the fire for the $2 \mathrm{~m} / \mathrm{s}$ air velocity test. Table 6-7 shows the time duration and opening condition for the $5 \mathrm{MW}$ fire tests. 
Table 6-7 Test characteristics for the $5 \mathrm{MW}$ fire exposed to different opening arrangement

\begin{tabular}{|c|c|c|c|c|c|c|c|}
\hline \multirow{3}{*}{$\begin{array}{l}\text { Make-up air } \\
\text { velocity } \\
(\mathrm{m} / \mathrm{s})\end{array}$} & \multirow[t]{3}{*}{$\begin{array}{l}\text { Opening } \\
\text { arrangement }\end{array}$} & \multirow{3}{*}{$\begin{array}{l}\text { Time } \\
\text { duration } \\
\text { (Sec) }\end{array}$} & \multicolumn{3}{|c|}{ Opening conditions } & \multicolumn{2}{|c|}{$\begin{array}{l}\text { Width }(m) \\
\text { Height }(m)\end{array}$} \\
\hline & & & \multirow[t]{2}{*}{1} & \multirow[t]{2}{*}{2} & \multirow[t]{2}{*}{3} & \multirow[t]{2}{*}{4} & 5 \\
\hline & & & & & & & Fan \\
\hline \multirow{10}{*}{1} & \multirow{2}{*}{4 sides } & \multirow{2}{*}{$500-1250$} & 3.00 & 3.60 & 3.60 & 3.40 & \multirow{2}{*}{ on } \\
\hline & & & 2.75 & 1.14 & 1.14 & 2.43 & \\
\hline & \multirow{2}{*}{$\begin{array}{l}\text { 2-opposite } \\
\text { sides }\end{array}$} & \multirow{2}{*}{$1350-2050$} & \multirow{2}{*}{-} & 3.60 & 3.60 & \multirow{2}{*}{ - } & \multirow{2}{*}{ on } \\
\hline & & & & 2.30 & 2.30 & & \\
\hline & \multirow{2}{*}{$\begin{array}{l}\text { 2-adjacent } \\
\text { sides }\end{array}$} & \multirow{2}{*}{$2150-2850$} & \multirow{2}{*}{-} & 3.60 & 3.60 & 3.40 & \multirow{2}{*}{ off } \\
\hline & & & & 2.30 & 2.30 & 4.85 & \\
\hline & \multirow{2}{*}{3 sides } & \multirow{2}{*}{$3000-3650$} & 3.00 & 3.60 & 3.60 & 3.40 & \multirow{2}{*}{ off } \\
\hline & & & 3.67 & 1.53 & 1.53 & 3.23 & \\
\hline & \multirow{2}{*}{1 side } & \multirow{2}{*}{$3800-4500$} & \multirow{2}{*}{-} & 3.60 & 3.60 & & \multirow{2}{*}{ off } \\
\hline & & & & 4.58 & 4.58 & 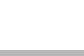 & \\
\hline & 4 sides & $700-1350$ & 3.00 & 3.60 & 3.60 & 3.40 & $0 n$ \\
\hline & 4 sines & סכנבי - & 1.83 & 0.76 & 0.76 & 1.62 & Uiा \\
\hline & 2-opposite & $1450-2050$ & - & 3.60 & 3.60 & - & $0 n$ \\
\hline & sides & $1400-2050$ & 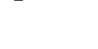 & 1.53 & 1.53 & 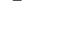 & Uiा \\
\hline 1.5 & 2-adjacent & $2150-2750$ & - & 3.60 & 3.60 & 3.40 & fff \\
\hline 1.0 & sides & $2+00-800$ & - & 1.53 & 1.53 & 3.23 & 011 \\
\hline & 3 sides & $2850-3450$ & 3.00 & 3.60 & 3.60 & 3.40 & off \\
\hline & & $2050-54 J 0$ & 2.45 & 1.02 & 1.02 & 2.15 & 011 \\
\hline & 1 side & $3550-4200$ & - & 3.60 & 3.60 & - & off \\
\hline & & $35 J U-4 \angle U O$ & & 3.05 & 3.05 & - & 011 \\
\hline & 4 sides & $1000-1550$ & 3.00 & 3.60 & 3.60 & 3.40 & on \\
\hline & 4 siaes & $1000-1530$ & 1.37 & 0.57 & 0.57 & 1.21 & on \\
\hline & 2-opposite & $1650-2150$ & - & 3.60 & 3.60 & & $n$ \\
\hline & sides & $1050-2130$ & 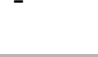 & 1.15 & 1.15 & - & Uiा \\
\hline 2 & 2-adjacent & $2250-2750$ & - & 3.60 & 3.60 & 3.40 & off \\
\hline & sides & & - & 1.15 & 1.15 & 2.42 & 011 \\
\hline & 3 sides & $2850-3350$ & 3.00 & 3.60 & 3.60 & 3.40 & off \\
\hline & & & 1.83 & 0.76 & 0.76 & 1.61 & $0 \pi$ \\
\hline & 1 side & $3450-4000$ & - & 3.60 & 3.60 & - & off \\
\hline & & & & 2.29 & 2.29 & & \\
\hline
\end{tabular}


The temperature profiles along the atrium height were calculated over a $200 \mathrm{sec}$ period of each steady condition and plotted in Figures 6-15 to 6-17. As these figures show, the big change in the vertical temperature profiles occurs from changing the opening arrangement from the 2-opposite side opening to the 2-adjacent sides opening. These figures also show that the change in temperature profiles for the $2 \mathrm{~m} / \mathrm{s}$ air velocity test is larger than the change in temperature profiles of the 1 and $1.5 \mathrm{~m} / \mathrm{s}$ air velocity tests.

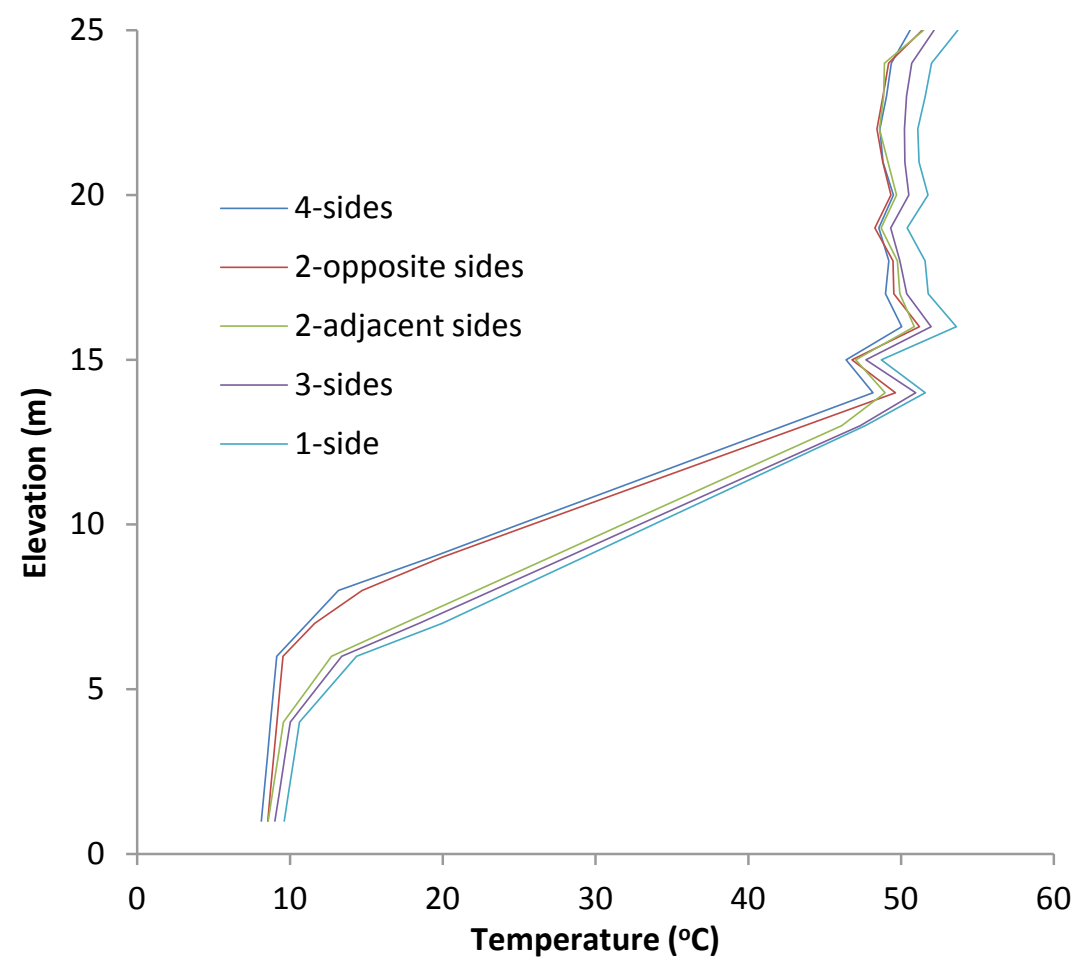

Figure 6-15 Vertical temperature profile for the $5 \mathrm{MW}$ fire test exposed to $1 \mathrm{~m} / \mathrm{s}$ air velocity 


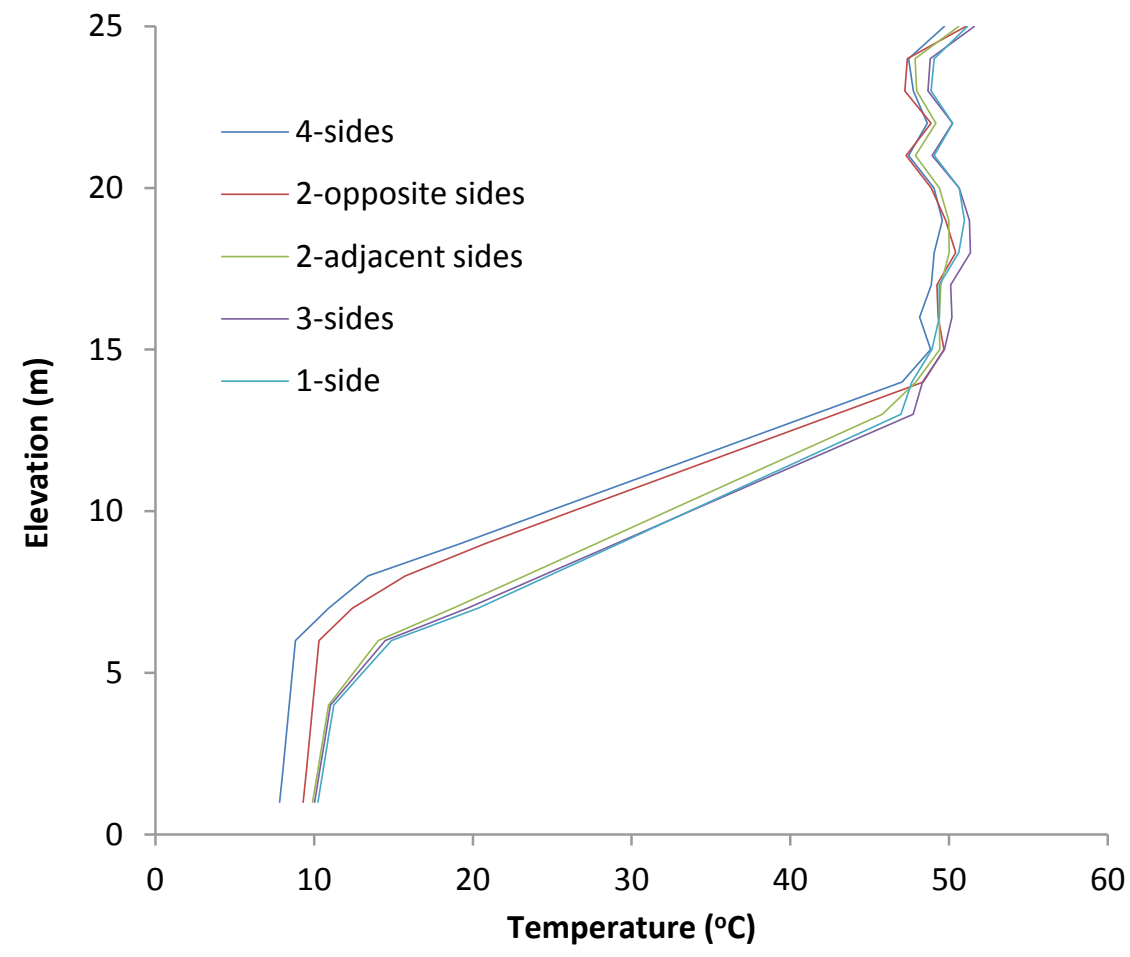

Figure 6-16 Vertical temperature profile for the $5 \mathrm{MW}$ fire test exposed to $1.5 \mathrm{~m} / \mathrm{s}$ air velocity

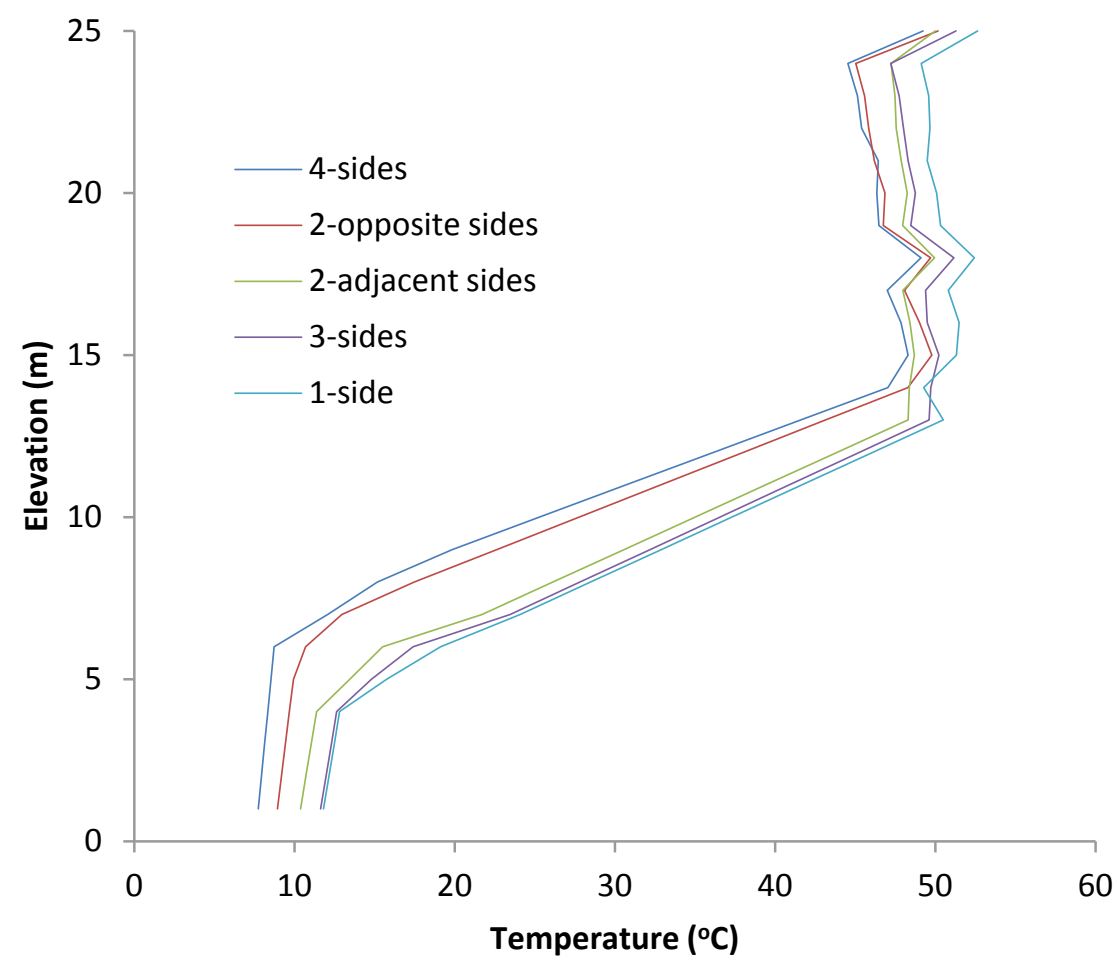

Figure 6-17 Vertical temperature profile for the $5 \mathrm{MW}$ fire test exposed to $2 \mathrm{~m} / \mathrm{s}$ air velocity 


\subsubsection{Discussion of Experimental Results}

The smoke layer height and the normalized values from the experimental data are listed in Table 6-8. This table shows the decrease in smoke layer height for the $5 \mathrm{MW}$ fire exposed to different make-up air velocities is very small. The values for the $1 \mathrm{~m} / \mathrm{s}$ and $1.5 \mathrm{~m} / \mathrm{s}$ air velocity tests are quite similar. For the $2 \mathrm{~m} / \mathrm{s}$ air velocity test the decrease is slightly larger than the decrease in the 1 and the $1.5 \mathrm{~m} / \mathrm{s}$ air velocity test. The smoke layer height is also shown in Figure 6-18. This figure shows that the smoke layer height is quite similar for the 4-side opening and the 2-opposite side opening arrangement. In addition, the difference between the results of the 2 -adjacent side test, the 3 -side and the 1 -side opening is very small. 
Table 6-8 Smoke Layer height in the $5 \mathrm{MW}$ fire test exposed to different opening arrangement

\begin{tabular}{|c|c|c|c|c|}
\hline \multicolumn{5}{|c|}{ Smoke layer height from Experiment } \\
\hline $\begin{array}{l}\text { Make-up air } \\
\text { velocity }\end{array}$ & $\begin{array}{l}\text { Opening } \\
\text { arrangement }\end{array}$ & $\begin{array}{l}\text { Visual } \\
\text { observation } \\
\text { (m) }\end{array}$ & $\begin{array}{l}\text { N-Percentage } \\
\text { Method } \\
\text { (m) }\end{array}$ & $\begin{array}{l}\text { Normalized } \\
\text { Value }\end{array}$ \\
\hline \multirow{5}{*}{$1 \mathrm{~m} / \mathrm{s}$} & Four sides & 8.5 & 8.57 & 1 \\
\hline & $\begin{array}{l}\text { Two-opposite } \\
\text { sides }\end{array}$ & 8.5 & 8.46 & 0.98 \\
\hline & $\begin{array}{l}\text { Two-adjacent } \\
\text { sides }\end{array}$ & 7 & 6.93 & 0.80 \\
\hline & Three sides & 7 & 6.84 & 0.79 \\
\hline & One side & 6.5 & 6.72 & 0.78 \\
\hline \multirow{5}{*}{$1.5 \mathrm{~m} / \mathrm{s}$} & Four sides & 8.5 & 8.48 & 1 \\
\hline & $\begin{array}{l}\text { Two-opposite } \\
\text { sides }\end{array}$ & 8.5 & 8.38 & 0.98 \\
\hline & $\begin{array}{l}\text { Two-adjacent } \\
\text { sides }\end{array}$ & 7 & 6.85 & 0.80 \\
\hline & Three sides & 6.5 & 6.71 & 0.79 \\
\hline & One side & 6.5 & 6.64 & 0.78 \\
\hline \multirow{5}{*}{$2 \mathrm{~m} / \mathrm{s}$} & Four sides & 8 & 8.18 & 1 \\
\hline & $\begin{array}{l}\text { Two-opposite } \\
\text { sides }\end{array}$ & 8 & 7.93 & 0.97 \\
\hline & $\begin{array}{l}\text { Two-adjacent } \\
\text { sides }\end{array}$ & 6.5 & 6.45 & 0.78 \\
\hline & Three sides & 6.5 & 6.35 & 0.77 \\
\hline & One side & 6 & 6.17 & 0.75 \\
\hline
\end{tabular}




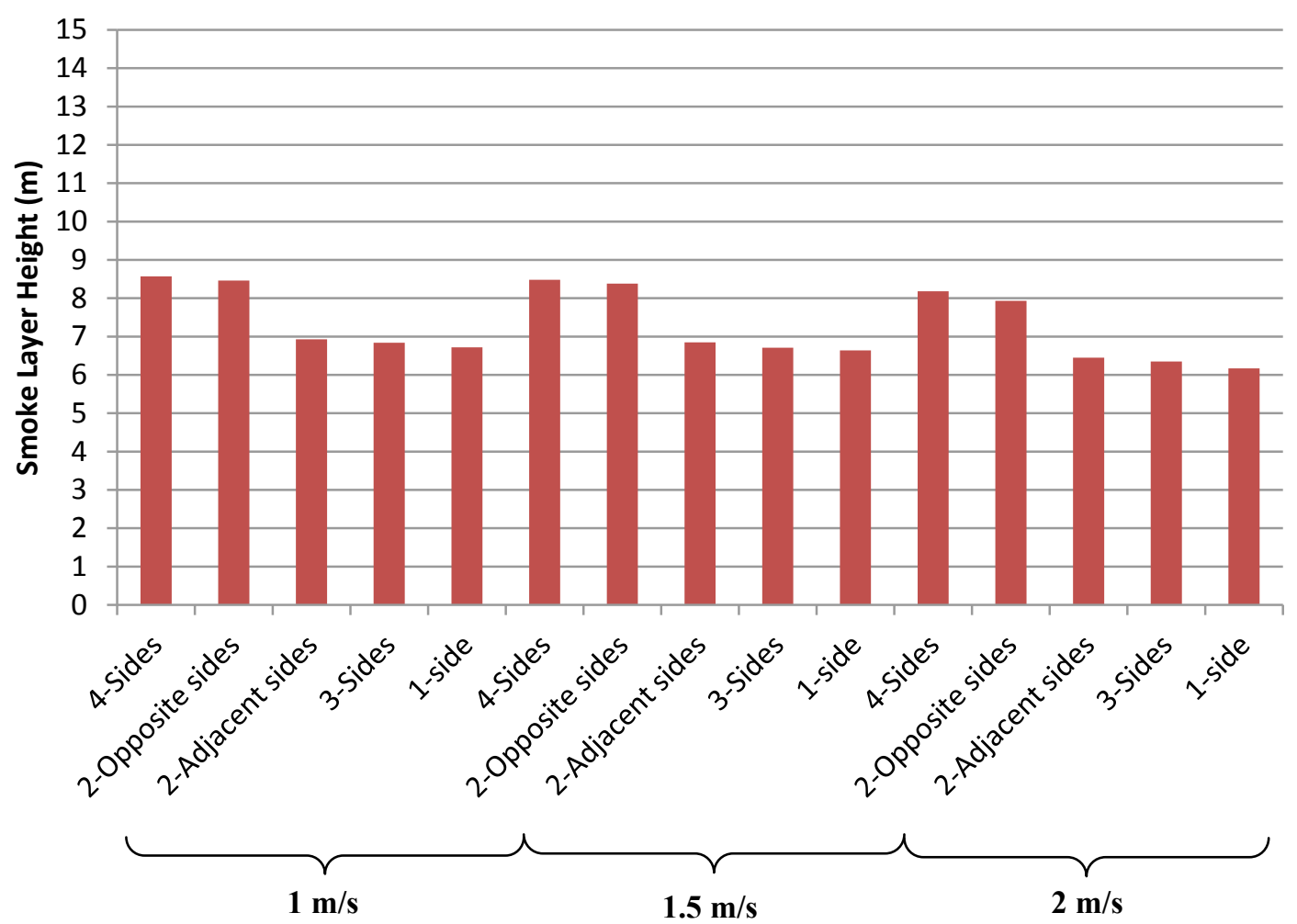

Figure 6-18 Smoke layer height in the 5 MW fire test exposed to different opening arrangement 


\subsection{2 $5 \mathrm{MW}$ Fire Test Simulation}

The $5 \mathrm{MW}$ fire tests have been modeled using FDS and each case was run for $600 \mathrm{sec}$ to ensure stable conditions in the atrium. The last $200 \mathrm{sec}$ of each case was used to obtain the average of the smoke layer height as shown in Table 6-9. The normalized values of the smoke layer height are also shown in this table. The normalized values show that the decrease of the smoke layer height for the $5 \mathrm{MW}$ fire is smaller than the simulation results of the 1 and the $2 \mathrm{MW}$ fire. The CFD model predicts well the decrease due to the opening arrangement change from 2-opposite side opening to 2adjacent side opening. In addition, the changes between the 4-side opening and the 2oposite side opening and also between the 2-adjacent side, the 3-sides and the 1-side opening are negligible. Figure 6-19 shows the smoke layer height in CFD modelling of the $5 \mathrm{MW}$ fire. 
Table 6-9 Smoke layer height from CFD modelling of the 5 MW fire test exposed to different opening arrangement

\begin{tabular}{|c|c|c|c|c|}
\hline \multicolumn{5}{|c|}{ Smoke layer height from CFD modelling } \\
\hline $\begin{array}{l}\text { Make-up air } \\
\text { velocity }\end{array}$ & $\begin{array}{l}\text { Opening } \\
\text { arrangement }\end{array}$ & $\begin{array}{l}\text { Design } \\
\text { (m) }\end{array}$ & $\begin{array}{l}\text { CFD Modeling } \\
\text { (m) }\end{array}$ & $\begin{array}{l}\text { Normalized } \\
\text { Value }\end{array}$ \\
\hline \multirow{5}{*}{$1 \mathrm{~m} / \mathrm{s}$} & Four sides & 9 & 7.42 & 1 \\
\hline & $\begin{array}{l}\text { Two-opposite } \\
\text { sides }\end{array}$ & 9 & 7.28 & 0.98 \\
\hline & $\begin{array}{l}\text { Two-adjacent } \\
\text { sides }\end{array}$ & 9 & 6.25 & 0.84 \\
\hline & Three sides & 9 & 6.04 & 0.81 \\
\hline & One side & 9 & 6.18 & 0.83 \\
\hline \multirow{5}{*}{$1.5 \mathrm{~m} / \mathrm{s}$} & Four sides & 9 & 7.11 & 1 \\
\hline & $\begin{array}{l}\text { Two-opposite } \\
\text { sides }\end{array}$ & 9 & 6.92 & 0.97 \\
\hline & $\begin{array}{l}\text { Two-adjacent } \\
\text { sides }\end{array}$ & 9 & 5.82 & 0.81 \\
\hline & Three sides & 9 & 5.52 & 0.77 \\
\hline & One side & 9 & 5.68 & 0.79 \\
\hline \multirow{5}{*}{$2 \mathrm{~m} / \mathrm{s}$} & Four sides & 9 & 6.71 & 1 \\
\hline & $\begin{array}{l}\text { Two-opposite } \\
\text { sides }\end{array}$ & 9 & 6.45 & 0.96 \\
\hline & $\begin{array}{l}\text { Two-adjacent } \\
\text { sides }\end{array}$ & 9 & 5.45 & 0.81 \\
\hline & Three sides & 9 & 5.21 & 0.77 \\
\hline & One side & 9 & 5.29 & 0.78 \\
\hline
\end{tabular}




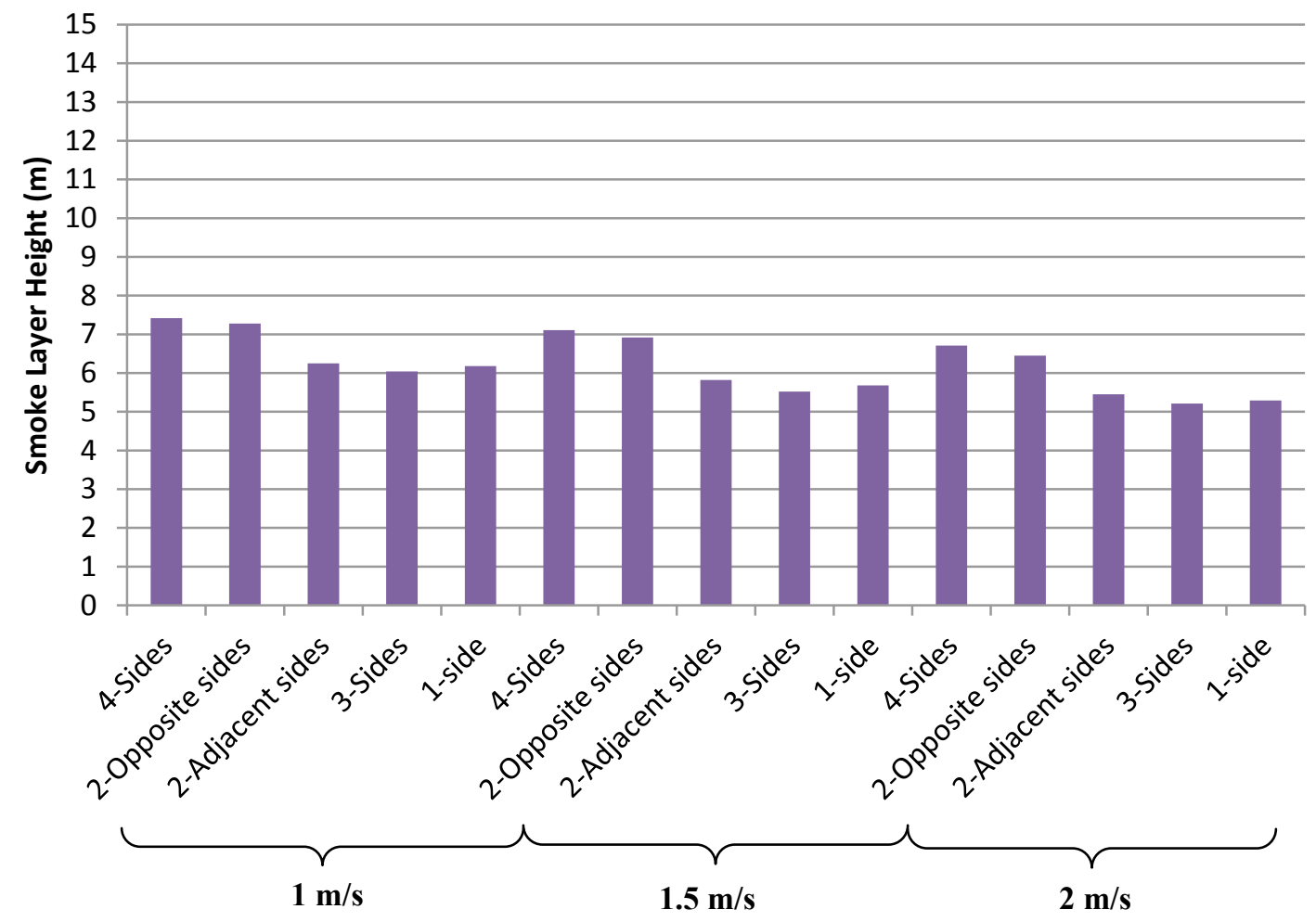

Figure 6-19 Smoke layer height from CFD modelling of the $5 \mathrm{MW}$ fire test exposed to different opening arrangement 


\subsection{Data Comparison}

A comparison of the experimental data with the correlation computed values is shown in Figures 6-20 to 6-22. It was assumed that the correlation values correspond to the 0 $\mathrm{m} / \mathrm{s}$ make-up air velocity, as the correlations were developed based on the a smoke plume not affected by air flows. The test data has been taken from the 4-side opening test, as the difference between the 4-sides and the 2-sides opening is very small. The points on the graph were taken from dividing the test data by the correlation predictions, which for $1 \mathrm{MW}$ fire has been previously calculated at $12.93 \mathrm{~m}$, for $2 \mathrm{MW}$ fire has been calculated at 11.2 and for $5 \mathrm{MW}$ fire has been calculated at $9 \mathrm{~m}$.

In order to develop a correlation to calculate the smoke layer height for different air velocities and different fire sizes, trend lines were determined to represent the impact of the make-up air velocity on the results of the 1,2 and $5 \mathrm{MW}$ fire tests shown in Figures 6-20 to 6-22. Due to the limited number of data points, the following assumptions were made for developing the trend lines:

1. The correlation estimations of smoke layer height correspond to a $0 \mathrm{~m} / \mathrm{s}$ make-up air velocity.

2. The trend lines for the ratio of experimental data to the correlation estimation must not be greater than 1.0 for any values of air velocity.

3. The trend lines must be monotonic.

4. The trend lines must decrease with increasing the air velocity. 
5. The order of the trend lines must be the same for the 1,2 and $5 \mathrm{MW}$ test results.

After several trials it was found that the best fit to the data was achieved by using a third order trend line.

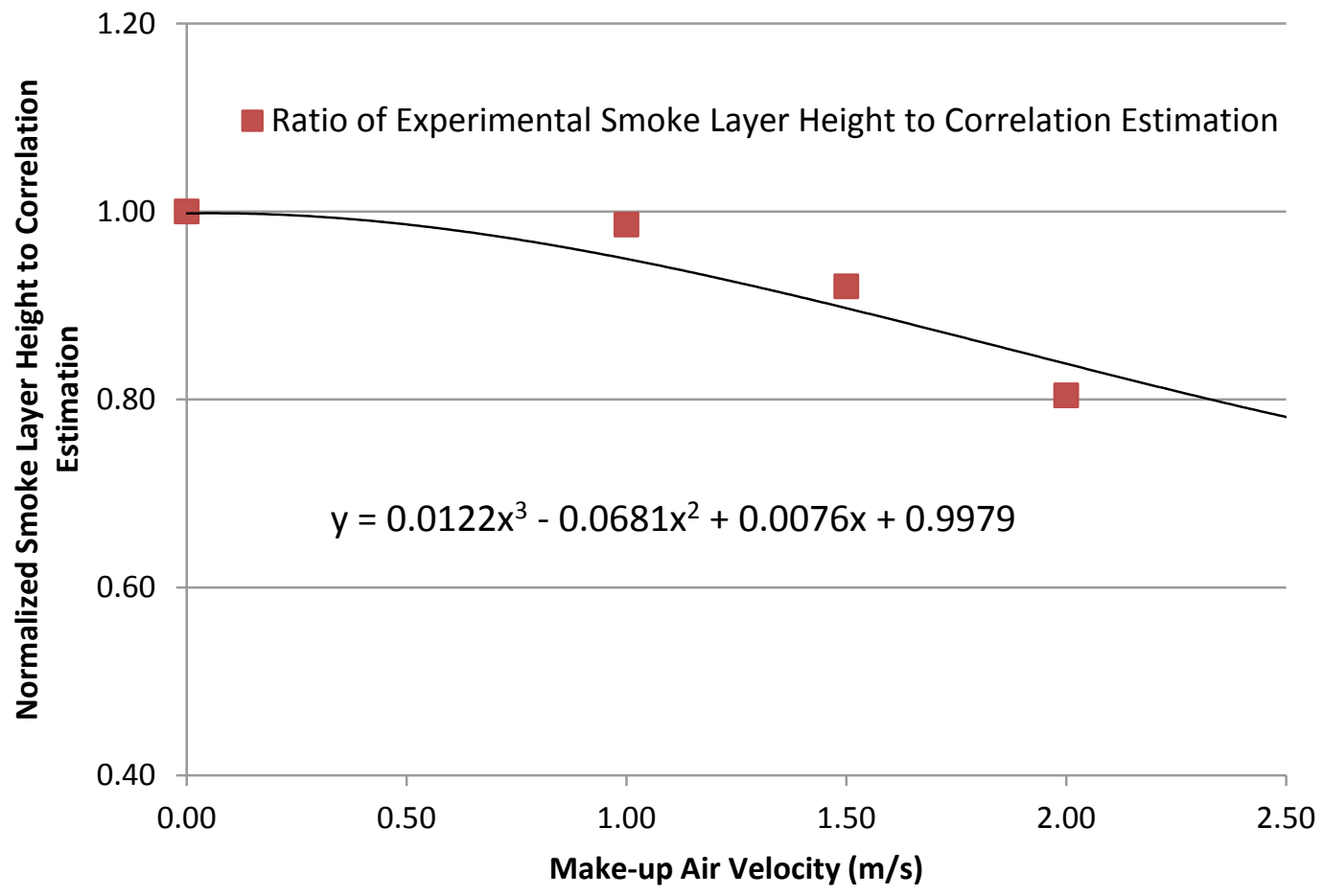

Figure 6-20 Comparison of smoke layer height with the correlations estimation for the $1 \mathrm{MW}$ fire 


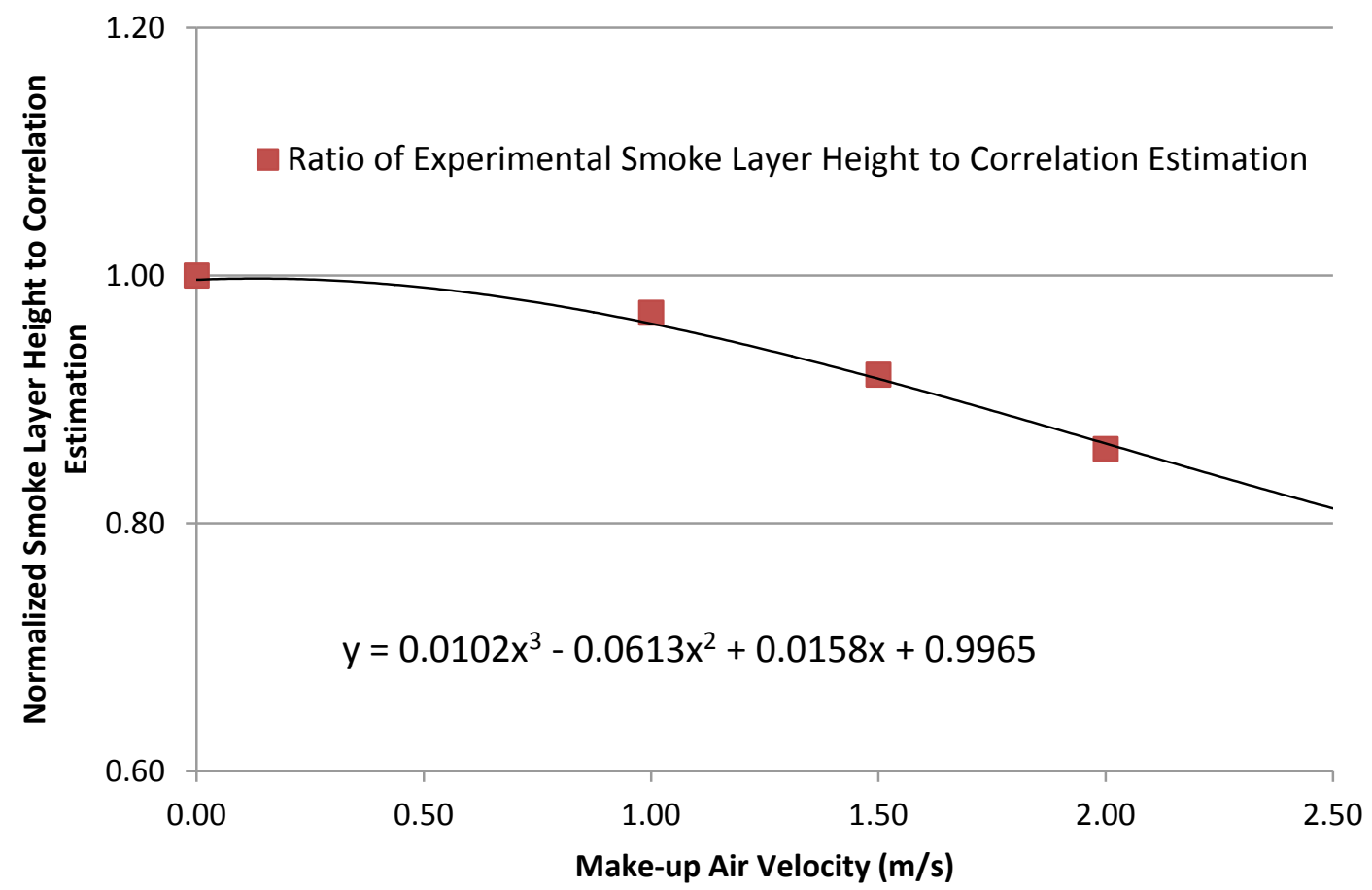

Figure 6-21 Comparison of smoke layer height with the correlations estimation for the 2 MW fire

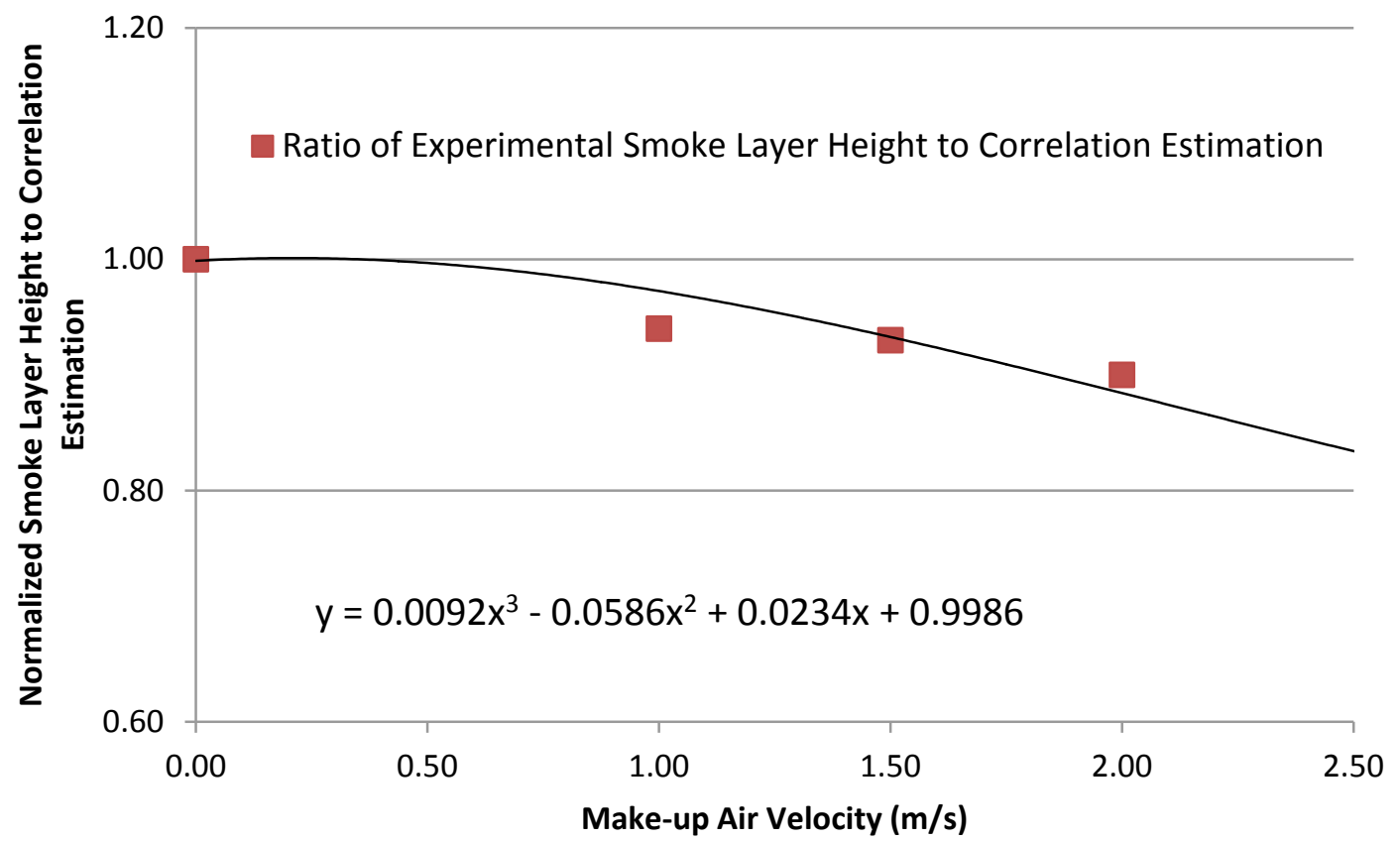

Figure 6-22 Comparison of smoke layer height with the correlations estimation for the $5 \mathrm{MW}$ fire 


\subsection{Conclusion}

In this chapter the effect of make-up air opening arrangements on the smoke layer height for 1, 2 and $5 \mathrm{MW}$ atrium fires was discussed. The exhaust rate was set to a

constant value of $33 \mathrm{~m}^{3} / \mathrm{sec}$ and the make-up air velocity was controlled by adjusting the opening area. The make-up air velocity has been monitored to ensure the required make-up air velocity was provided by the openings.

Providing fresh air from all four sides of the atrium resulted in good agreement between the correlation predictions and the experimental results. Asymmetric opening locations caused a drop of the smoke layer height. The one-side opening caused the largest drop of the interface height. The CFD modeling results had almost the same trend as the experimental data in estimating the smoke interface height for different opening configurations.

A comparison of smoke layer height from experiments and simulations is shown in Figures 6-23 to 6-25. Although both the experimental data and the simulation results showed that asymmetric openings in the atrium decrease the smoke interface height, the CFD model over predicts the smoke depth.

As discussed earlier, Kerber and Milke (2007) studied the effect of opening arrangement including four sides and two-adjacent sides opening with 1 and $2 \mathrm{~m} / \mathrm{s}$ make-up air velocity by conducting CFD modelling. This result is consistent with 
Kerber and Milke's conclusion (2007) that the asymmetric opening increases the smoke disturbance and decreases the smoke layer height in the atrium.

In addition, the smoke layer height decreases with increasing the make-up air velocity, however the changes are larger for the small fires than the big fires. The results show good agreement with the results of Chapter 5 that showed that the make-up air velocity of $1 \mathrm{~m} / \mathrm{s}$ is not too restrictive. For small fires the make-up air velocity of $1.5 \mathrm{~m} / \mathrm{s}$ yields approximately similar results as the $1 \mathrm{~m} / \mathrm{s}$ make-up air velocity and for big fires the smoke layer height starts to be affected at the $2 \mathrm{~m} / \mathrm{s}$ make-up air velocity.

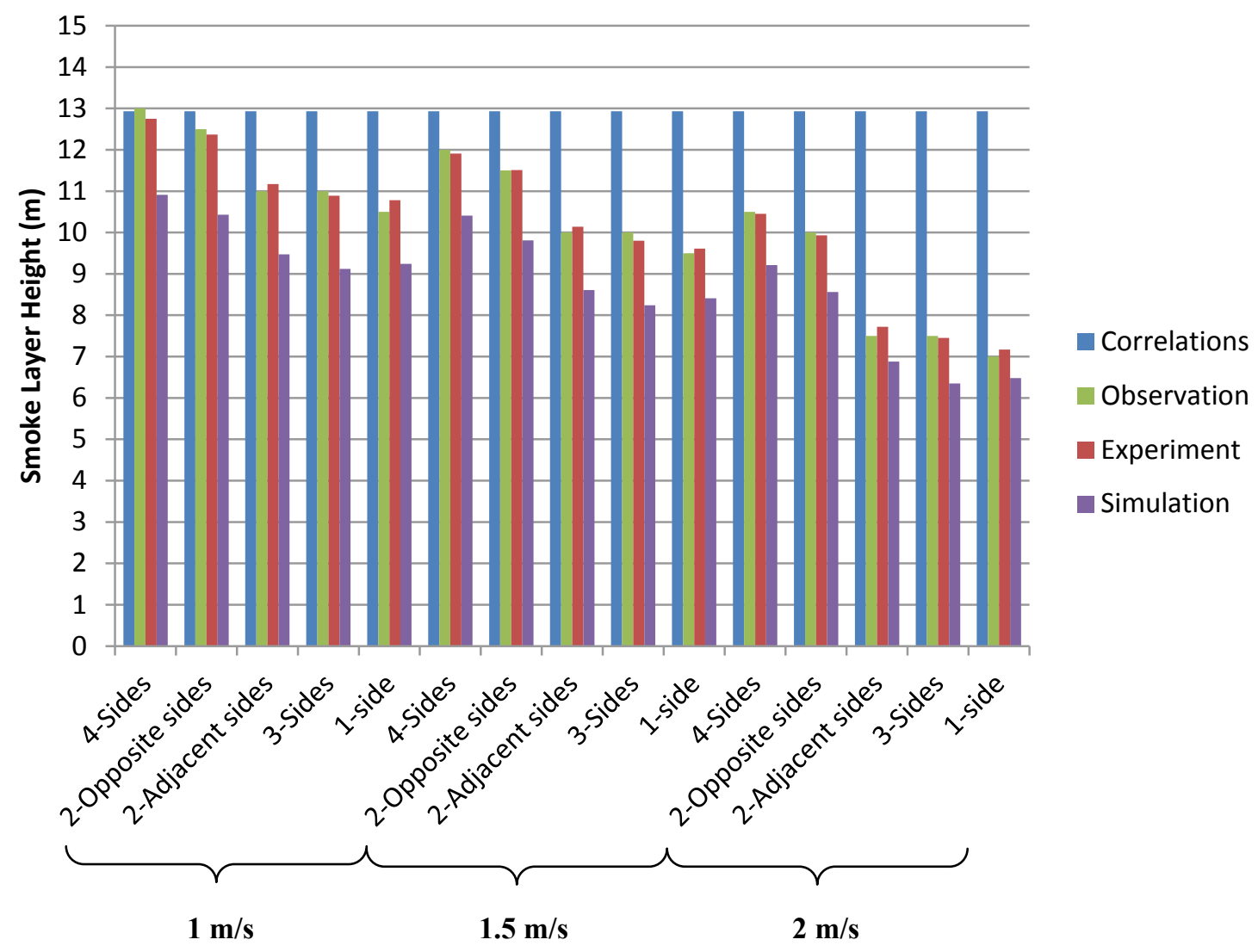

Figure 6-23 Comparison of smoke layer height for the 1 MW fire 


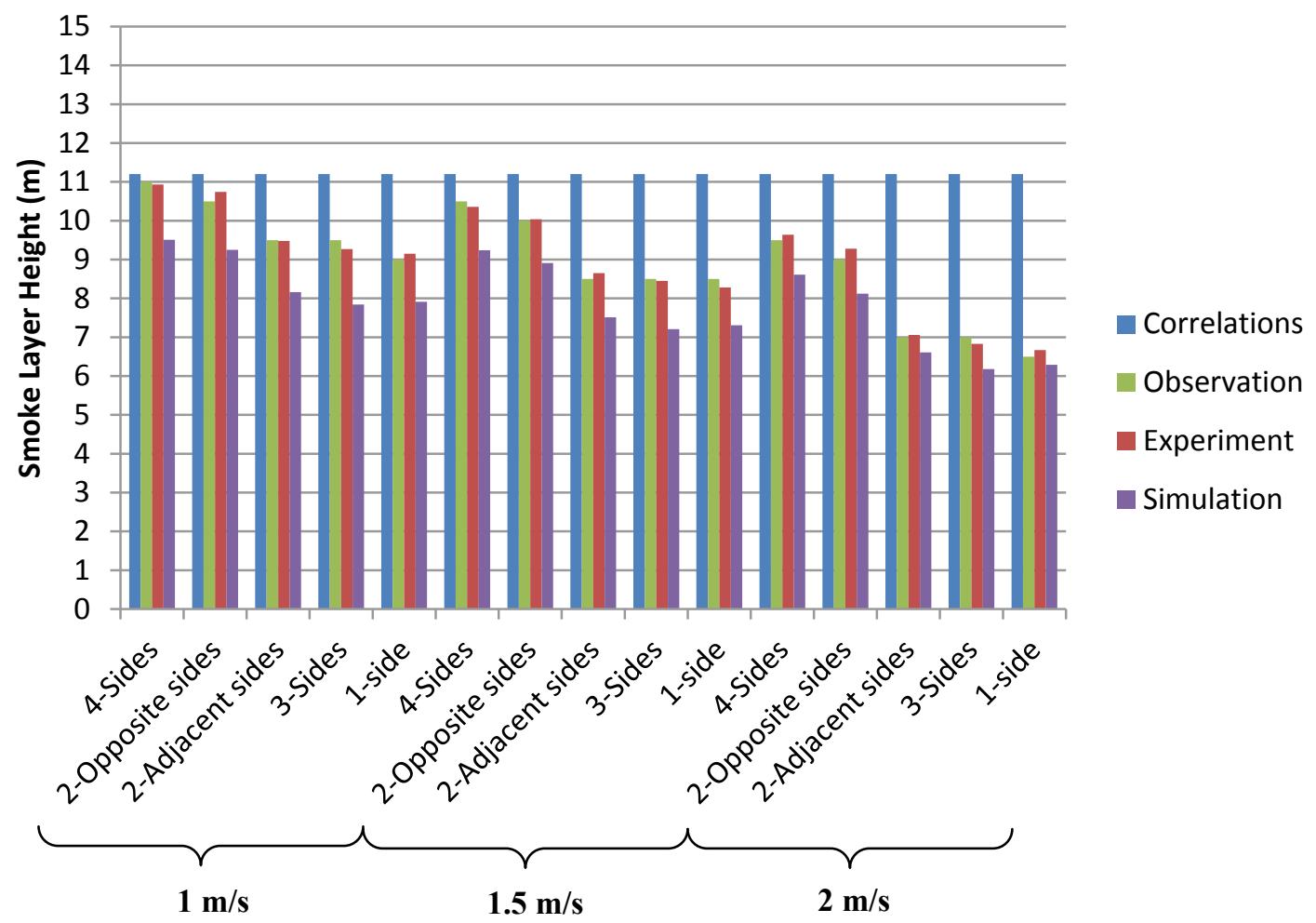

Figure 6-24 Comparison of smoke layer height for the $2 \mathrm{MW}$ fire

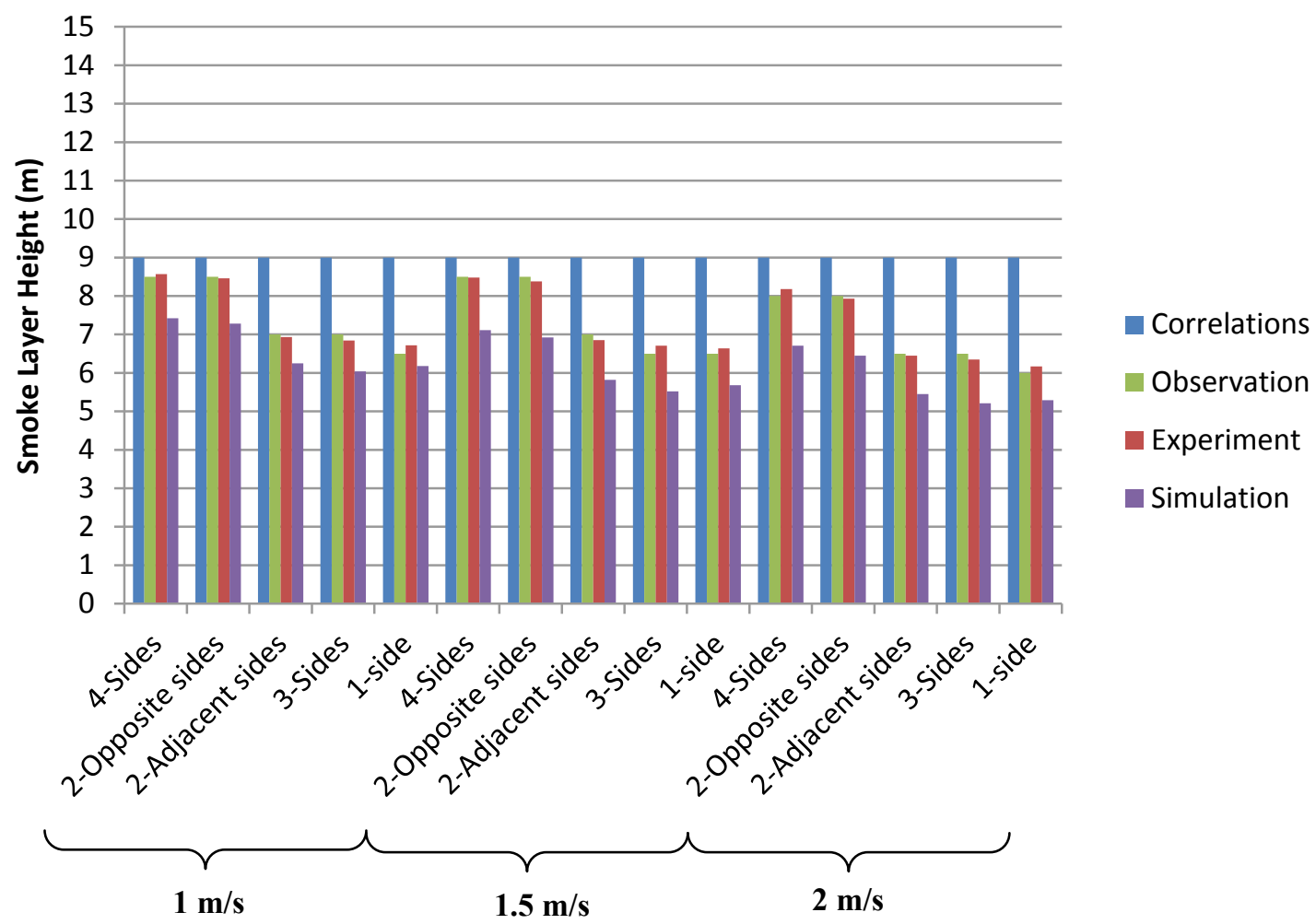

Figure 6-25 Comparison of smoke layer height for the 5 MW fire 
A correlation is proposed to estimate the effect of the make-up air velocity on the smoke conditions in the atrium after a trial and error process. This correlation calculates a reduction factor which should be applied to the predicted smoke interface height computed using the atrium correlations. Since the CFD modelling results follows a similar trend to the experimental data, the proposed correlation might be valid for the calculated smoke layer height from simulation.

$$
R F=\frac{1}{2.688 \dot{Q}_{c}^{\frac{1}{2}}} V^{3}-\frac{1}{1.2 \dot{Q}_{c}^{\frac{1}{3}}} V^{2}+\frac{1}{120} V+1
$$

Where:

$\mathrm{RF}=$ Reduction Factor

$\mathrm{V}=$ Air velocity, $\mathrm{m} / \mathrm{s}$

$\dot{Q}_{c}=$ Convective heat release rate, $\mathrm{kW}(0.65 \sim 0.7 \dot{Q})$

This correlation was developed from the trend line of the 4-side opening arrangement test results, as the test results from the 4-side opening arrangement and the 2 side opening arrangement show that the symmetric openings yield very similar heights for the smoke layer.

A comparison of the smoke layer height predicted by existing correlations, smoke layer height adjusted by the reduction factor correlation, the experimental results and the simulation estimations are shown in Figures 6-26 to 6-28. The experimental data and the simulation results are an average of the smoke layer height from the 4-side opening and 2-opposite side opening in each case. 


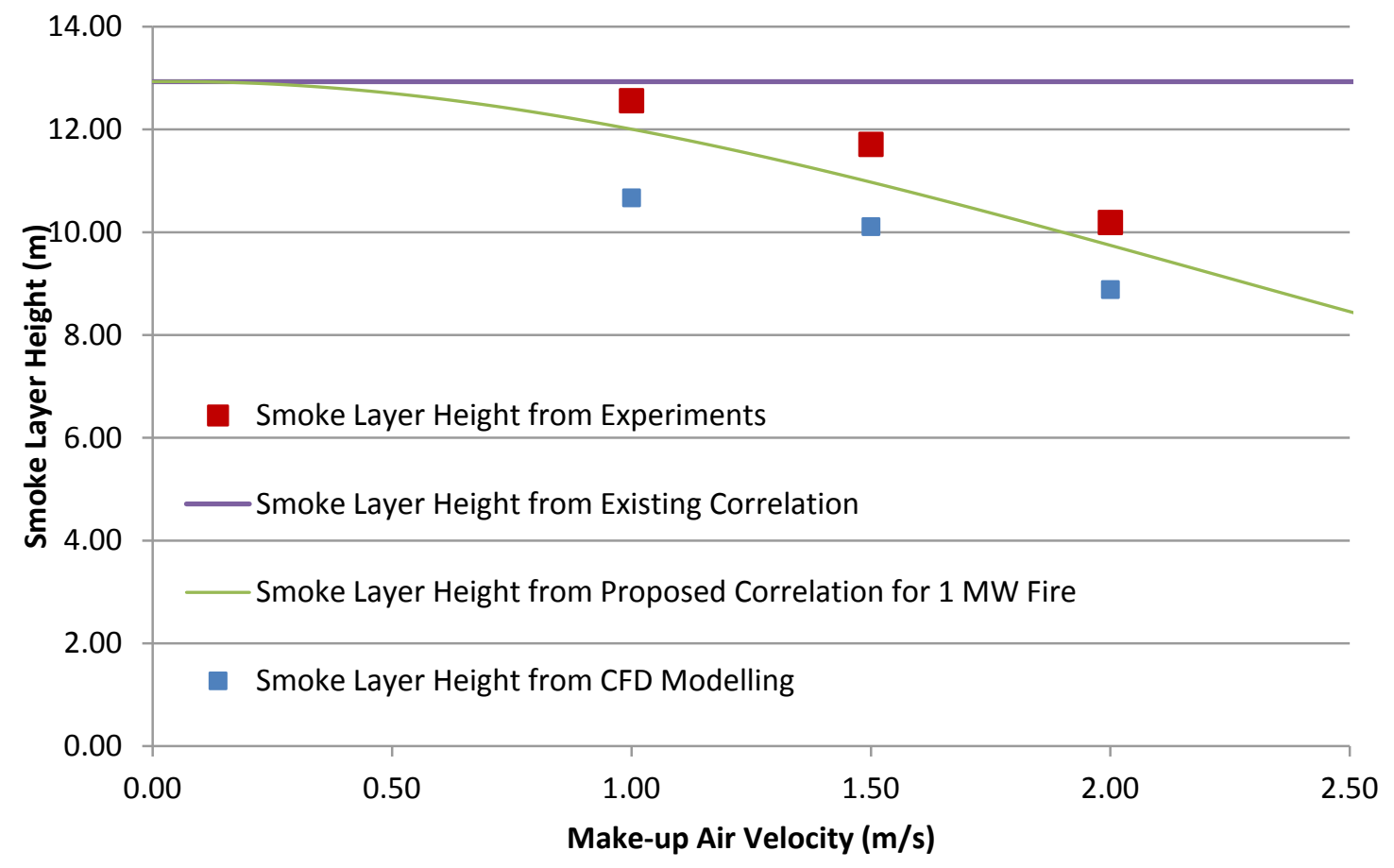

Figure 6-26 Proposed reduction factor correlation for the 1 MW fire with symmetric opening arrangement

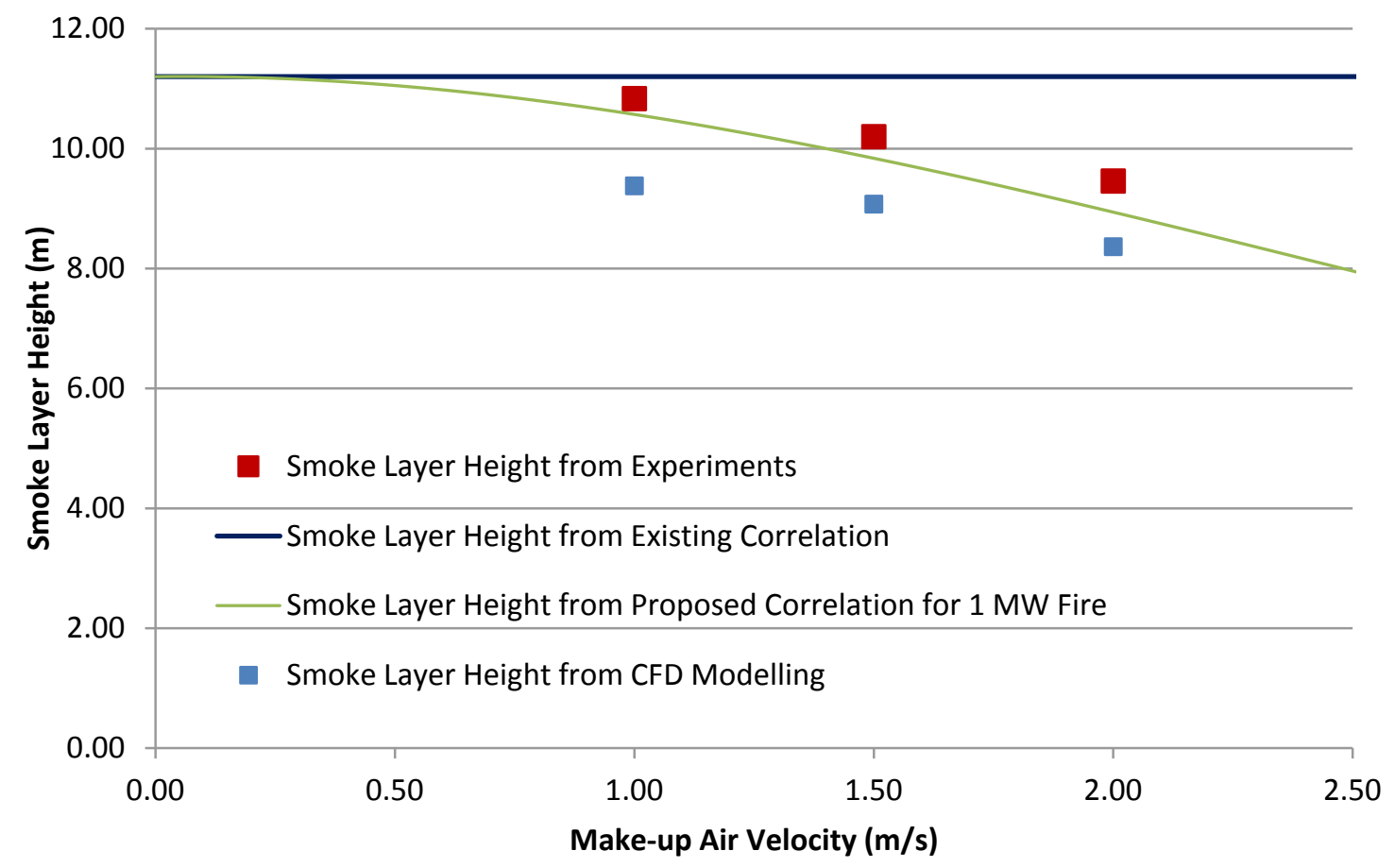

Figure 6-27 Proposed reduction factor correlation for the 2 MW fire with symmetric opening arrangement 


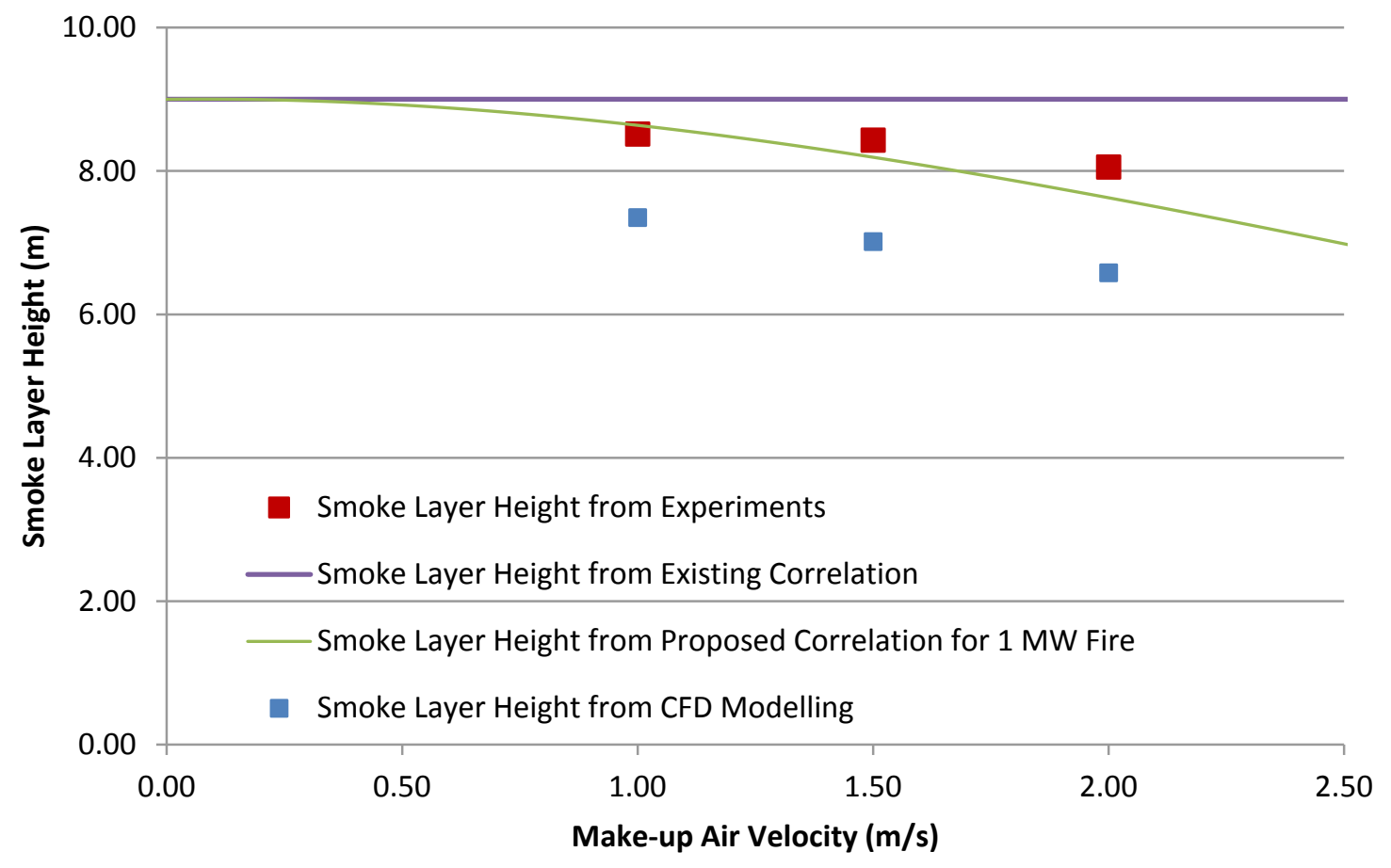

Figure 6-28 Proposed reduction factor correlation for the 5 MW fire with symmetric opening arrangement

The proposed correlation is valid for make-up air velocities in the range of $0 \mathrm{~m} / \mathrm{s}$ to 4 $\mathrm{m} / \mathrm{s}$ and for fire sizes larger than $600 \mathrm{~kW}$. The $600 \mathrm{~kW}$ fire is commonly the smallest design fire in the atrium which can activate the smoke management system.

To check the confidence level of the proposed correlation, the standard error was calculated using:

$$
\sigma_{e s t}=\sqrt{\frac{\sum\left(H_{e x p}-H_{\text {pro }}\right)^{2}}{n}}
$$


Where:

$\sigma_{e s t}=$ Standard error of the estimate

$\mathrm{H}_{\text {exp }}=$ Smoke layer height from the experiment, $\mathrm{m}$

$\mathrm{H}_{\text {pro }}=$ Smoke layer height from the proposed correlation, $\mathrm{m}$

$\mathrm{n}=$ Number of data in each series of test

Table 6-10 shows the standard error of the proposed correlation for the symmetric opening arrangement. The standard error indicates that the proposed correlation provides a good prediction of the smoke layer height in the case of symmetric opening arrangement. Moreover, it shows that the proposed correlation provides a better estimation of the smoke interface height for the big fires, as the standard error decreases with increasing the fire size.

Table 6-10 Standard error of the proposed correlation in the case of symmetric opening arrangement

\begin{tabular}{|c|c|c|c|c|c|}
\hline $\begin{array}{l}\text { Opening } \\
\text { arrangement }\end{array}$ & Fire size & $\begin{array}{l}\text { Make-up air } \\
\text { velocity }\end{array}$ & $\begin{array}{l}\text { Smoke layer } \\
\text { height from } \\
\text { experiment } \\
\text { (m) }\end{array}$ & $\begin{array}{l}\text { Smoke layer } \\
\text { height from } \\
\text { proposed } \\
\text { correlation } \\
\text { (m) }\end{array}$ & $\begin{array}{l}\text { Standard } \\
\text { error } \\
\left(\sigma_{\text {est }}\right)\end{array}$ \\
\hline \multirow{3}{*}{ Symmetric } & \multirow{3}{*}{$1 \mathrm{MW}$} & $1 \mathrm{~m} / \mathrm{s}$ & 12.56 & 12.01 & \multirow{3}{*}{0.5901} \\
\hline & & $1.5 \mathrm{~m} / \mathrm{s}$ & 11.71 & 10.97 & \\
\hline & & $2 \mathrm{~m} / \mathrm{s}$ & 10.19 & 9.74 & \\
\hline \multirow{3}{*}{ Symmetric } & \multirow{3}{*}{$2 \mathrm{MW}$} & $1 \mathrm{~m} / \mathrm{s}$ & 10.84 & 10.57 & \multirow{3}{*}{0.3972} \\
\hline & & $1.5 \mathrm{~m} / \mathrm{s}$ & 10.20 & 9.84 & \\
\hline & & $2 \mathrm{~m} / \mathrm{s}$ & 9.46 & 8.94 & \\
\hline \multirow{3}{*}{ Symmetric } & \multirow{3}{*}{$5 \mathrm{MW}$} & $1 \mathrm{~m} / \mathrm{s}$ & 8.52 & 8.64 & \multirow{3}{*}{0.2933} \\
\hline & & $1.5 \mathrm{~m} / \mathrm{s}$ & 8.43 & 8.19 & \\
\hline & & $2 \mathrm{~m} / \mathrm{s}$ & 8.06 & 7.63 & \\
\hline
\end{tabular}


It is also proposed to multiply the reduction factor correlation by an extra reduction factor to consider the effect of asymmetric opening.

$$
R F=f_{a}\left(\frac{1}{2.688 \dot{Q}_{c}^{\frac{1}{2}}} V^{3}-\frac{1}{1.2 \dot{Q}_{c}^{\frac{1}{3}}} V^{2}+\frac{1}{120} V+1\right)
$$

Where:

$f_{a}$ is the opening arrangement factor and is given by:

$$
f_{a}= \begin{cases}1 & \text { symmetric opening arrangement } \\ & \\ -0.13 V+1 & \text { asymmetric opening arrangement }\end{cases}
$$

Since the experimental data and CFD modelling results agree that the smoke layer height for the asymmetric opening arrangement including 3-side opening, 2-adjacent opening and 1-side opening are similar, the factor of asymmetric opening is applicable for all of the three asymmetric opening configurations. A comparison of the smoke layer height predicted by the existing correlations, smoke layer height adjusted by the reduction factor correlation for the asymmetric opening arrangement, the experimental results and the simulation estimations are shown in Figures 6-29 to 6-31. The experimental data and the simulation results are an average of the smoke layer height from the 3 -side opening, 2-adjacent opening and 1-side opening in each case. 


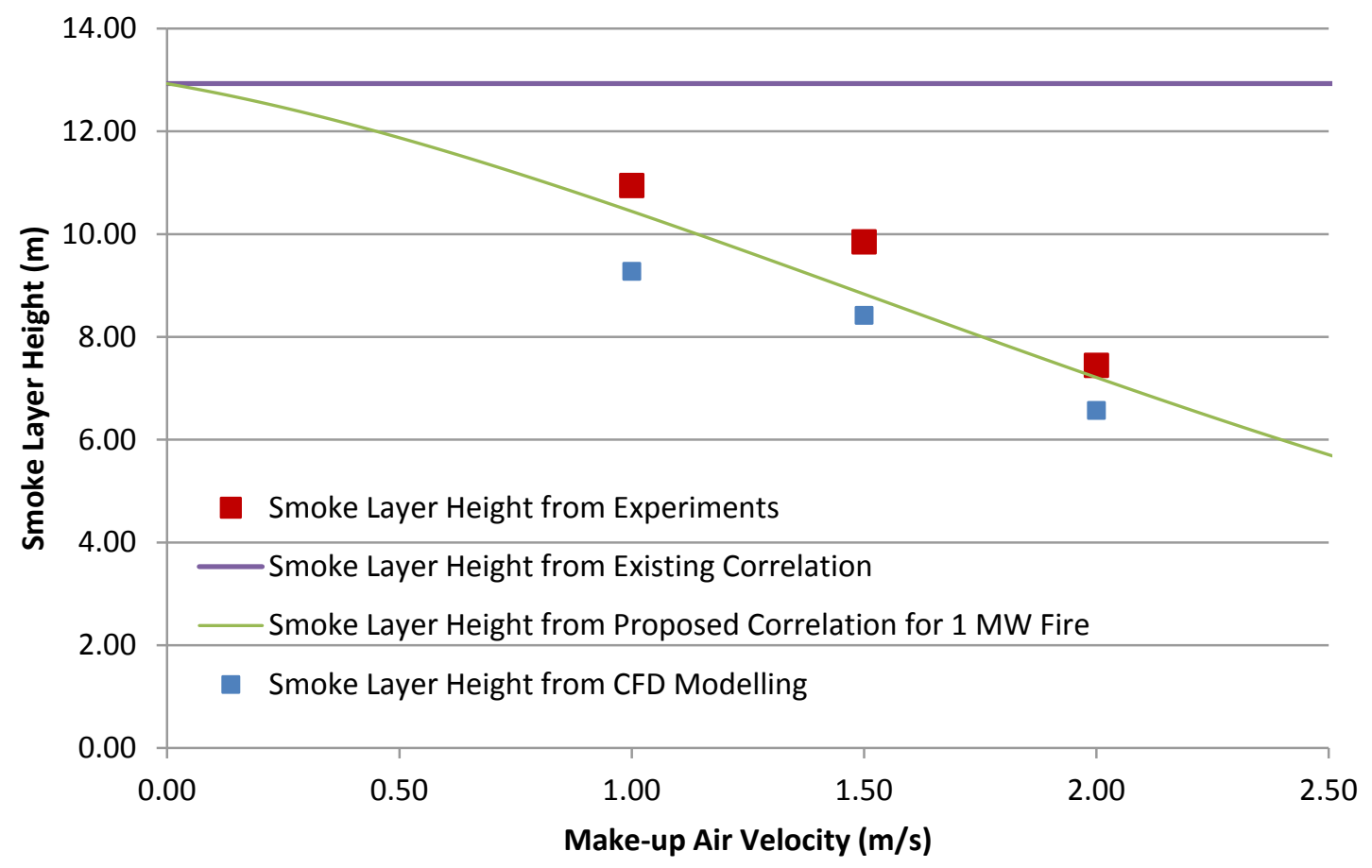

Figure 6-29 Proposed reduction factor correlation for the 1 MW fire with asymmetric opening arrangement

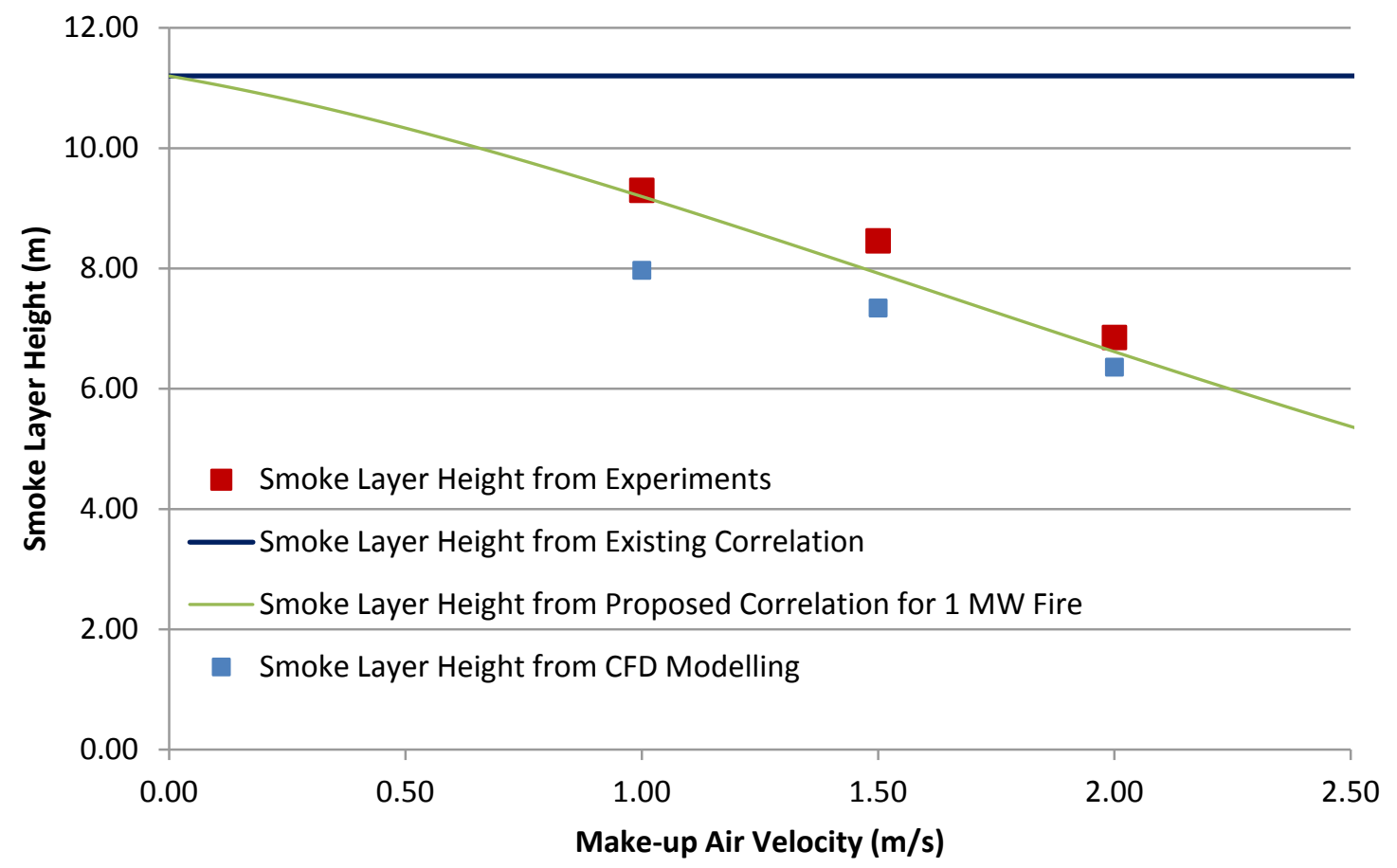

Figure 6-30 Proposed reduction factor correlation for the 2 MW fire with asymmetric opening arrangement 


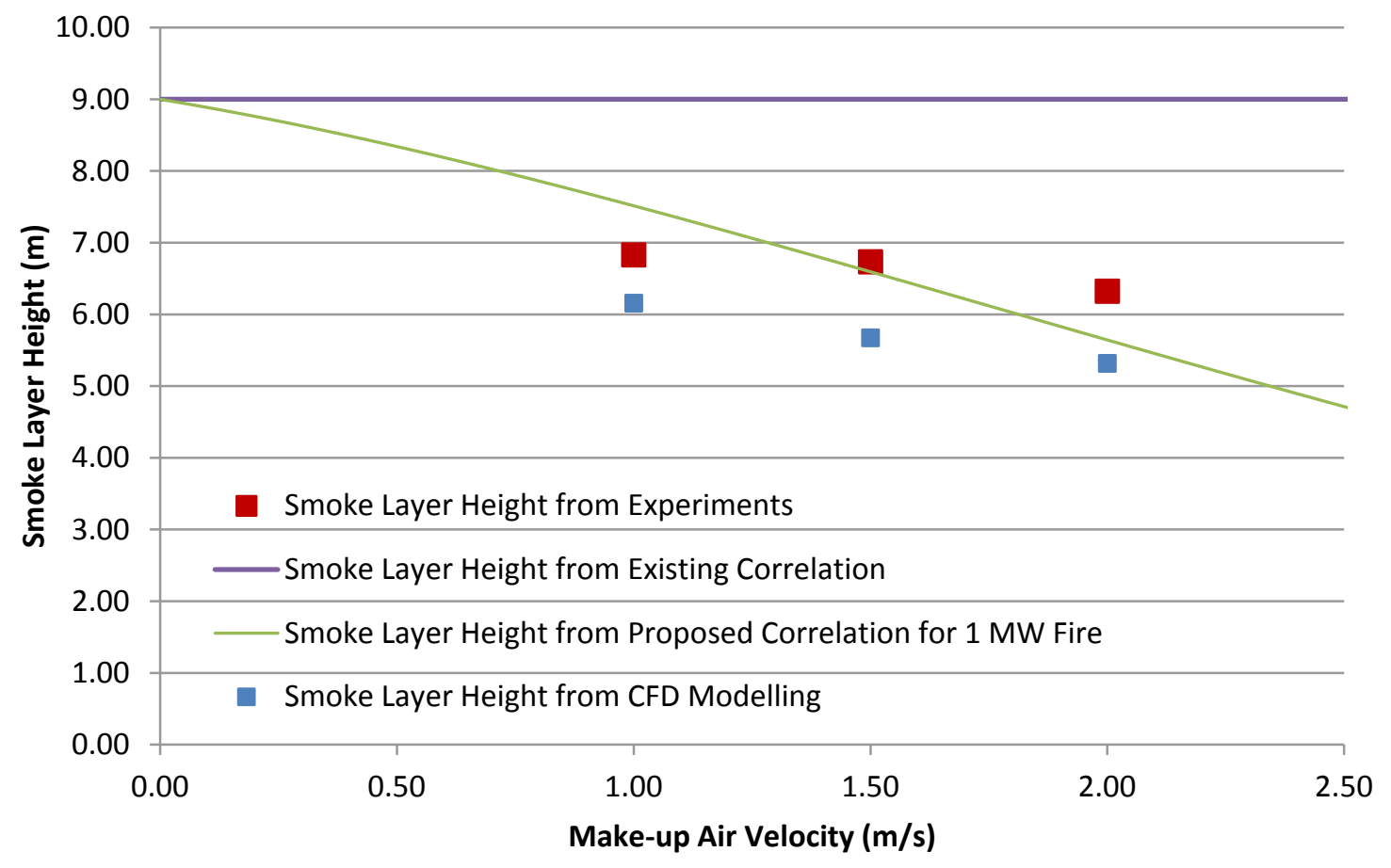

Figure 6-31 Proposed reduction factor correlation for the 5 MW fire with asymmetric opening arrangement

The standard error of the proposed correlation in the case of asymmetric opening arrangement is listed in Table 6-11. This table shows that the confidence level of the proposed correlation is acceptable. The smallest standard error for the asymmetric opening arrangement corresponds to the $2 \mathrm{MW}$ fire. . 
Table 6-11 Standard error of the proposed correlation in the case of asymmetric opening

\begin{tabular}{|c|c|c|c|c|c|}
\hline & & ari & gement & & \\
\hline \multirow[t]{2}{*}{$\begin{array}{l}\text { Opening } \\
\text { arrangement }\end{array}$} & Fire size & $\begin{array}{l}\text { Make-up air } \\
\text { velocity }\end{array}$ & $\begin{array}{l}\text { Smoke layer } \\
\text { height from } \\
\text { experiment }\end{array}$ & $\begin{array}{l}\text { Smoke layer } \\
\text { height from } \\
\text { proposed } \\
\text { correlation } \\
\text { (m) }\end{array}$ & $\begin{array}{l}\text { Standard } \\
\text { error } \\
\left(\sigma_{\text {est }}\right)\end{array}$ \\
\hline & \multirow{3}{*}{$1 \mathrm{MW}$} & $1 \mathrm{~m} / \mathrm{s}$ & 10.95 & 10.44 & \multirow{3}{*}{0.6689} \\
\hline \multirow[t]{3}{*}{ Asymmetric } & & $1.5 \mathrm{~m} / \mathrm{s}$ & 9.85 & 8.83 & \\
\hline & & $2 \mathrm{~m} / \mathrm{s}$ & 7.45 & 7.21 & \\
\hline & \multirow{3}{*}{$2 \mathrm{MW}$} & $1 \mathrm{~m} / \mathrm{s}$ & 9.30 & 9.20 & \multirow{3}{*}{0.3450} \\
\hline \multirow[t]{2}{*}{ Asymmetric } & & $1.5 \mathrm{~m} / \mathrm{s}$ & 8.46 & 7.92 & \\
\hline & & $2 \mathrm{~m} / \mathrm{s}$ & 6.85 & 6.61 & \\
\hline \multirow{3}{*}{ Asymmetric } & \multirow{3}{*}{$5 \mathrm{MW}$} & $1 \mathrm{~m} / \mathrm{s}$ & 6.83 & 7.51 & \multirow{3}{*}{0.5610} \\
\hline & & $1.5 \mathrm{~m} / \mathrm{s}$ & 6.73 & 6.59 & \\
\hline & & $2 \mathrm{~m} / \mathrm{s}$ & 6.32 & 5.64 & \\
\hline
\end{tabular}




\section{Chapter 7: Effects of Air Flow Direction on Atrium Smoke Conditions}

\subsection{Introduction}

This chapter presents the results of full-scale experiments and CFD modelling of atrium fires exposed to rotational make-up air with speed of $1,1.5$ and $2 \mathrm{~m} / \mathrm{s}$ and fire sizes of 1, 2 and $5 \mathrm{MW}$. The fire tests have been simulated with FDS5, and the results of the CFD modelling have been compared to the full-scale tests results and results from atrium correlations.

Kerber and Milke (2007) considered corner openings which are equally distributed along the height of the atrium and a make-up air velocity of $2 \mathrm{~m} / \mathrm{s}$. Locating openings at high elevations in the atrium causes the fresh air to enter directly into the smoke layer, mixing with the smoke and increases the thickness of the smoke layer. Placing the corner openings close to the level of first indication of smoke causes the rotational fresh air to mix with thin smoke and results in a larger transition zone. Figure 7-1 compares the effect of direct air flow and rotational make-up air in CFD modelling. 

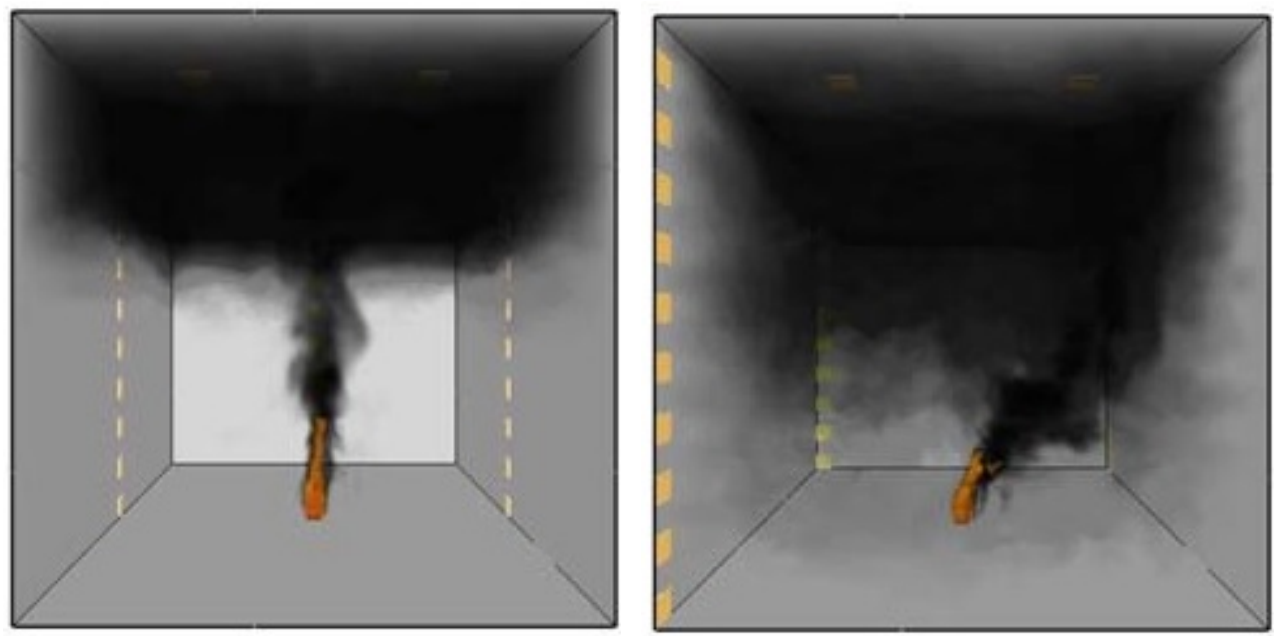

Figure 7-1 Effect of rotational make-up air on smoke layer height in CFD modeling [Kerber, S. and Milke, J. A. (2007)]

In this chapter, experiments have been conducted using two arrangements of the supply air with respect to the fire:

a. The make-up air blowing directly to the fire

b. The make-up air rotates around the fire 


\subsection{Atrium Set-up}

Figure 7-2 illustrates the atrium for directed air flow tests and Figure 7-3 shows the atrium set up for the rotational make-up air tests. The openings have been labelled with numbers.

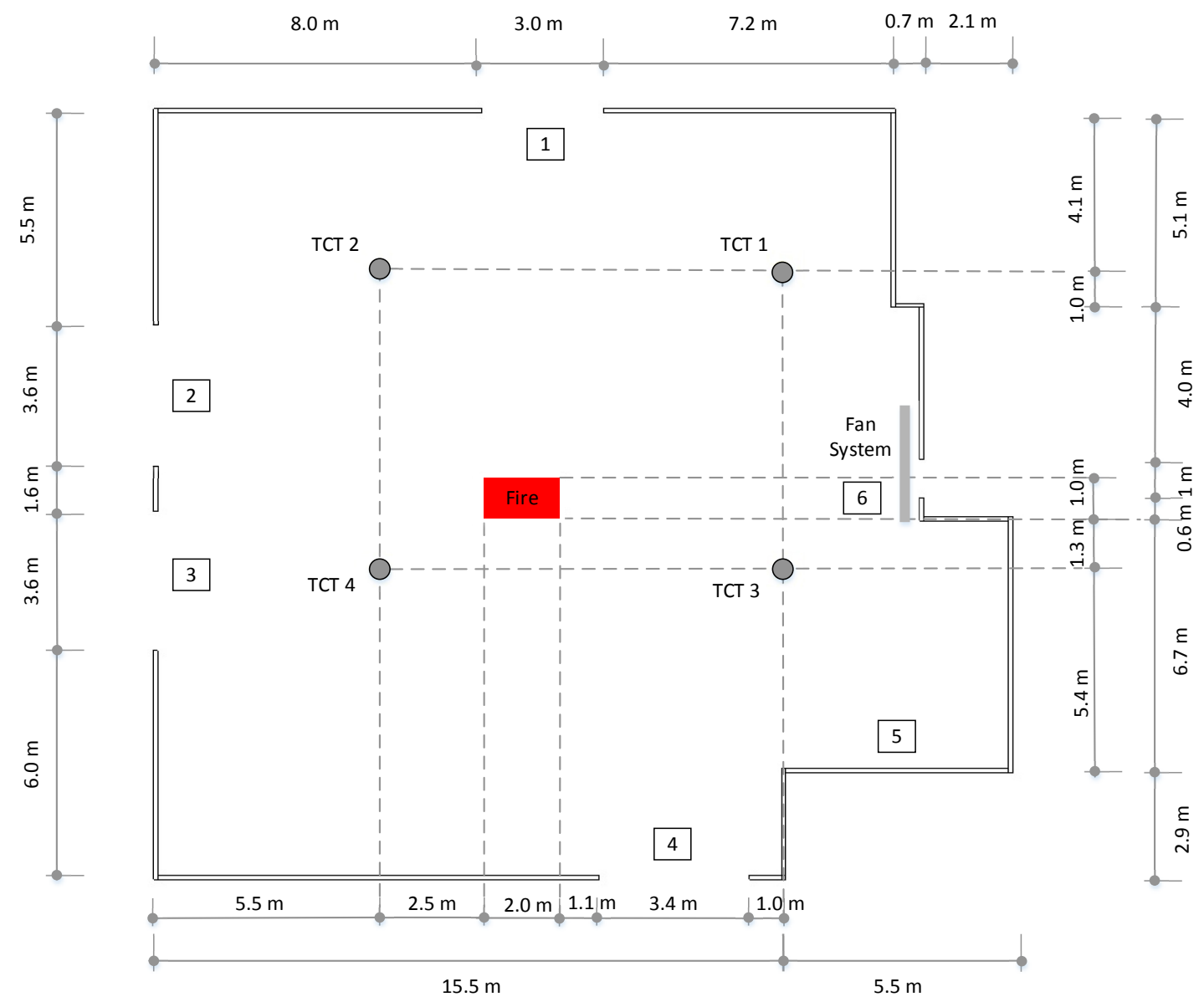

Figure 7-2 Atrium geometry for direct air flow test 


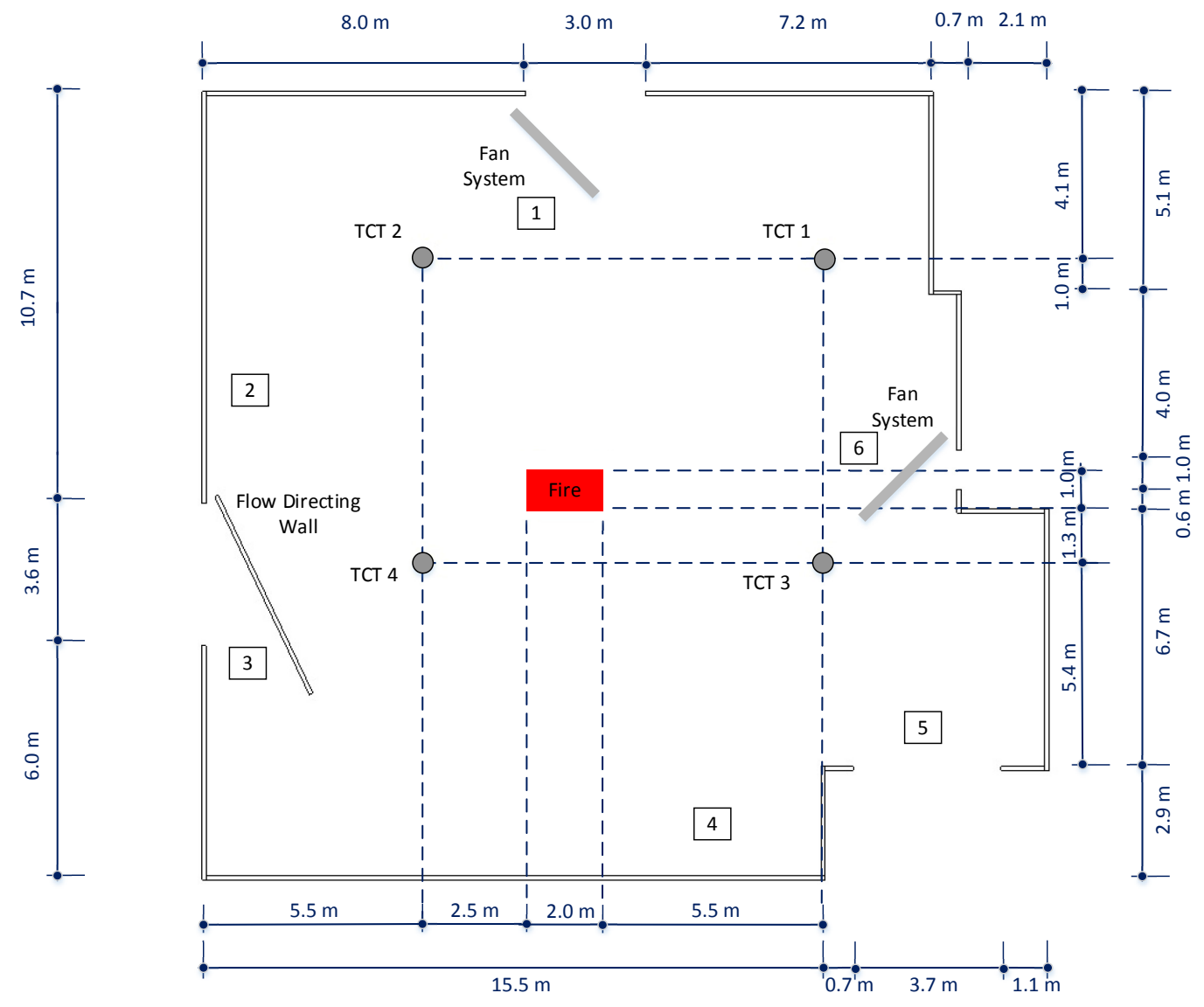

Figure 7-3 Atrium geometry for rotational make-up air test

\subsection{Full-Scale Tests}

Nine full-scale fire tests have been conducted to investigate the effect of $1,1.5$ and 2 $\mathrm{m} / \mathrm{s}$ rotational make-up air on the smoke conditions in the atrium, with 1, 2 and $5 \mathrm{MW}$ fires placed in the middle of the atrium. The atrium conditions were allowed to reach steady state and remain at steady state for about 900 to $1000 \mathrm{sec}$. The average temperature profile is calculated over a $200 \mathrm{sec}$ period of steady state conditions in each test.

Due to limitations of the openings in the corner of the atrium, two fan systems have been used to simulate two openings in the corners of the atrium for the rotational make- 
up air tests. The rotational make-up air velocity was monitored by air velocity measuring devices at several points close to the corners of the atrium before starting the test to ensure the required velocity was provided.

The rotational make-up air tests results are compared to the direct air flow test results. The direct air flow tests results are those obtained from the 4- side opening arrangement tests in Chapter 6. Figures 7-4 and 7-5 show photos of the test in the atrium.

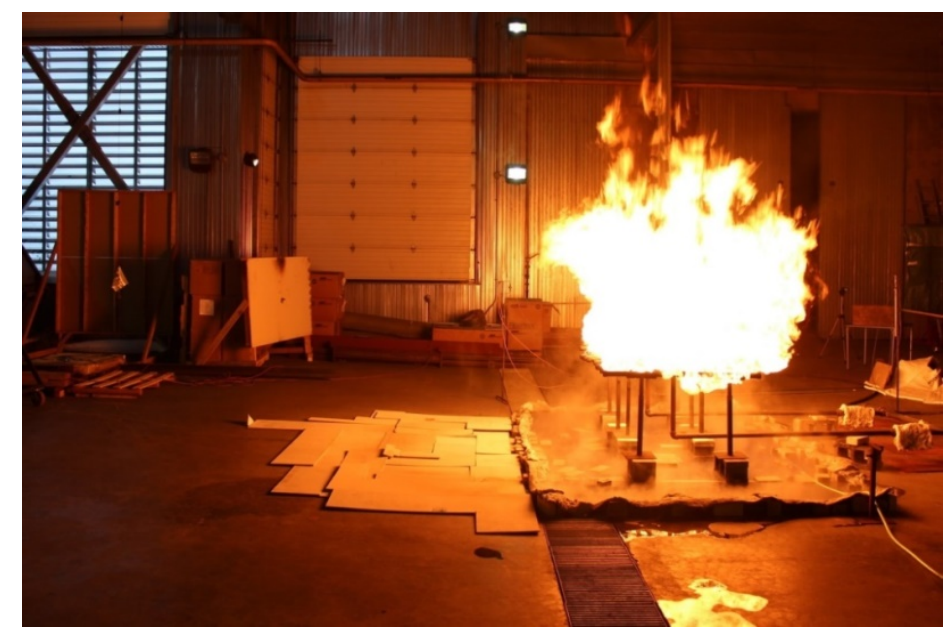

Figure 7-4 Rotational make-up air test in the atrium

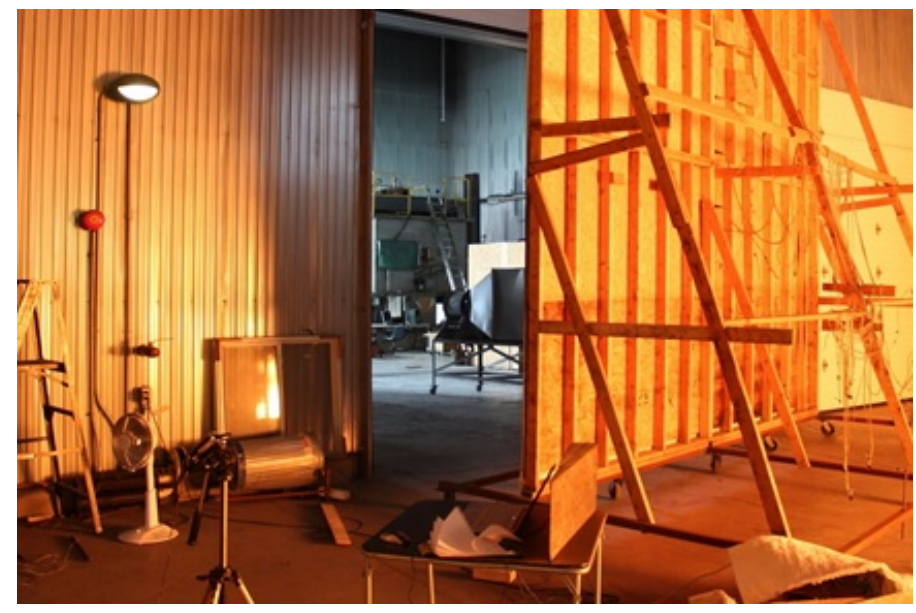

Figure 7-5 Blocking wall to orient the air flow in the atrium 


\subsection{MW Fire Test:}

The test started by turning on the smoke exhaust and the fan system for 10 min before starting the fire to reach steady state air flow conditions in the atrium. The exhaust system was set to $33 \mathrm{~m}^{3} / \mathrm{s}$ and atrium correlations estimate the smoke layer will be $12.93 \mathrm{~m}$ from the atrium floor.

\subsection{1 $1 \mathrm{~m} / \mathrm{s}$ Make-up Air Velocity:}

The smoke conditions have been monitored until steady state conditions at 600 sec. This test continued for $900 \mathrm{sec}$ and ended at $1500 \mathrm{sec}$. Table 7-1 shows the opening conditions for the rotational make-up air test and the direct air flow test. The ambient temperature has been measured at $3^{\circ} \mathrm{C}$ before starting the fire.

Table 7-1 Test characteristics for the $1 \mathrm{MW}$ fire exposed to the $1 \mathrm{~m} / \mathrm{s}$ rotational make-up air

\begin{tabular}{|c|c|c|c|c|c|c|c|}
\hline \multirow[t]{2}{*}{$\begin{array}{l}\text { Opening } \\
\text { arrangement }\end{array}$} & \multirow{2}{*}{$\begin{array}{l}\text { Time } \\
\text { duration } \\
\text { (Sec) }\end{array}$} & \multicolumn{3}{|c|}{ Opening conditions } & \multicolumn{3}{|c|}{$\begin{array}{l}\text { Width (m) } \\
\text { Height (m) }\end{array}$} \\
\hline & & 1 & 2 & 3 & 4 & 5 & 6 \\
\hline \multirow{2}{*}{ Direct Air } & From & 3.00 & 3.60 & 3.60 & 3.40 & \multirow{2}{*}{-} & \multirow[t]{2}{*}{ Fan } \\
\hline & Chapter 6 & 2.75 & 1.14 & 1.14 & 2.43 & & \\
\hline Rotational & \multirow{2}{*}{$600-1500$} & \multirow{2}{*}{ Fan } & \multirow{2}{*}{-} & 3.60 & \multirow{2}{*}{-} & 3.40 & \multirow[t]{2}{*}{ Fan } \\
\hline Make-Up Air & & & & 2.28 & & 2.43 & \\
\hline
\end{tabular}


A comparison of the average temperature profiles of the rotational make-up air test and the direct air flow test is shown in Figure 7-6. The average temperature profile has been calculated over the $200 \mathrm{sec}$ of steady state conditions of the test. This figure shows that the rotational make-up air causes a big change in the temperature profile along the atrium height.

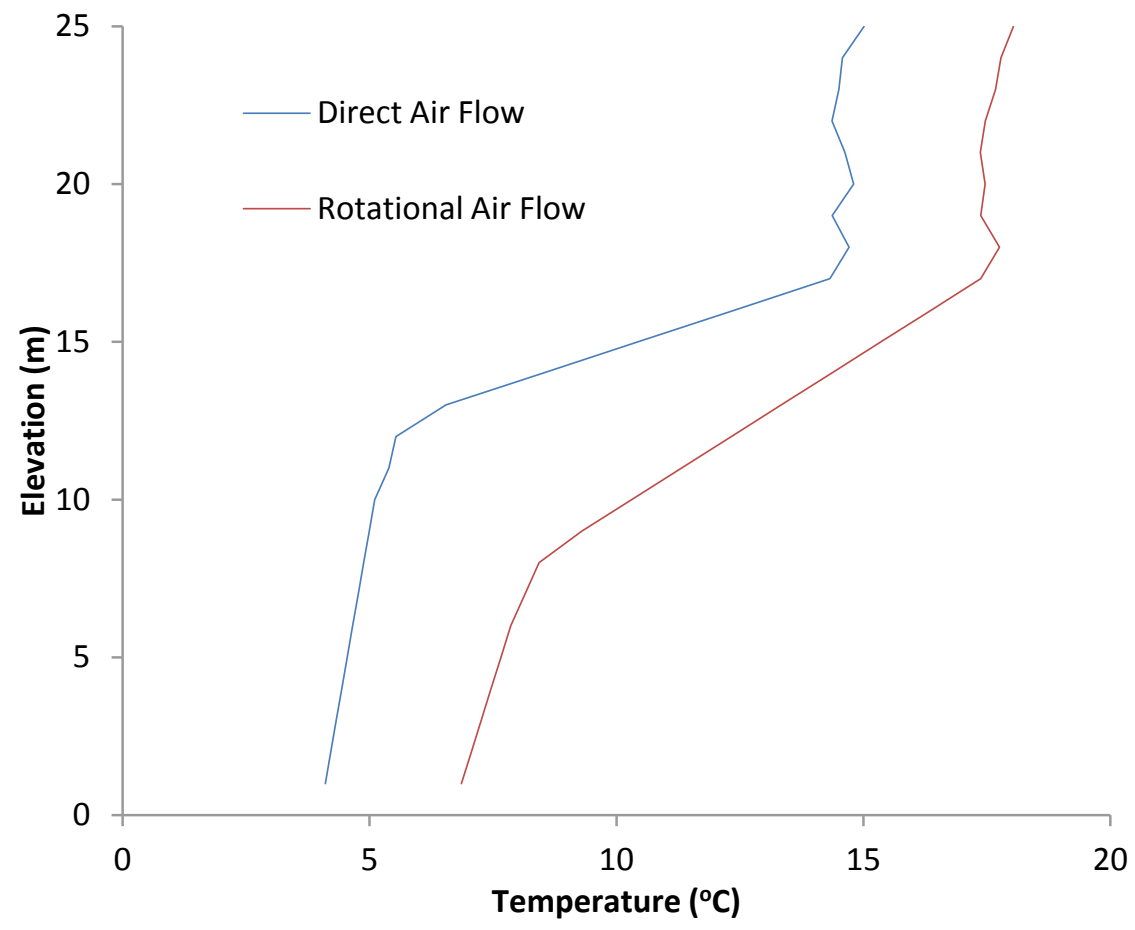

Figure 7-6 Vertical temperature profile for the $1 \mathrm{MW}$ fire test exposed to the $1 \mathrm{~m} / \mathrm{s}$ rotational make-up air velocity 


\subsection{2 $1.5 \mathrm{~m} / \mathrm{s}$ Make-up Air Velocity:}

The smoke condition in the atrium reached the stable condition at $500 \mathrm{sec}$ after starting the fire and it continued for $950 \mathrm{sec}$. The test ended at $1450 \mathrm{sec}$. The ambient temperature was at $1^{\circ} \mathrm{C}$ before starting the test. Table 7-2 shows the test characteristics for this test and the direct air flow test.

Table 7-2 Test characteristics for the $1 \mathrm{MW}$ fire exposed to the $1.5 \mathrm{~m} / \mathrm{s}$ rotational make-up air velocity

\begin{tabular}{|c|c|c|c|c|c|c|c|}
\hline \multirow[t]{2}{*}{$\begin{array}{l}\text { Opening } \\
\text { arrangement }\end{array}$} & \multirow{2}{*}{$\begin{array}{l}\text { Time } \\
\text { duration } \\
\text { (Sec) }\end{array}$} & \multicolumn{3}{|c|}{ Opening conditions } & \multicolumn{3}{|c|}{$\begin{array}{l}\text { Width (m) } \\
\text { Height (m) }\end{array}$} \\
\hline & & 1 & 2 & 3 & 4 & 5 & 6 \\
\hline \multirow{2}{*}{ Direct Air } & From & 3.00 & 3.60 & 3.60 & 3.40 & \multirow{2}{*}{-} & \multirow[t]{2}{*}{ Fan } \\
\hline & Chapter 6 & 1.83 & 0.76 & 0.76 & 1.62 & & \\
\hline Rotational & \multirow{2}{*}{$500-1450$} & \multirow{2}{*}{ Fan } & \multirow[b]{2}{*}{ - } & 3.60 & \multirow{2}{*}{-} & 3.40 & \multirow[t]{2}{*}{ Fan } \\
\hline Make-Up Air & & & & 1.52 & & 1.62 & \\
\hline
\end{tabular}


Figure 7-7 shows the average temperature profiles along the atrium height for the rational make-up air tests and the direct air flow test. This figure shows that the transition part of the profile starts at a lower height in the rotational make-up air test. This shows more turbulence in the smoke conditions for the rotational make-up air test than the direct air flow test.

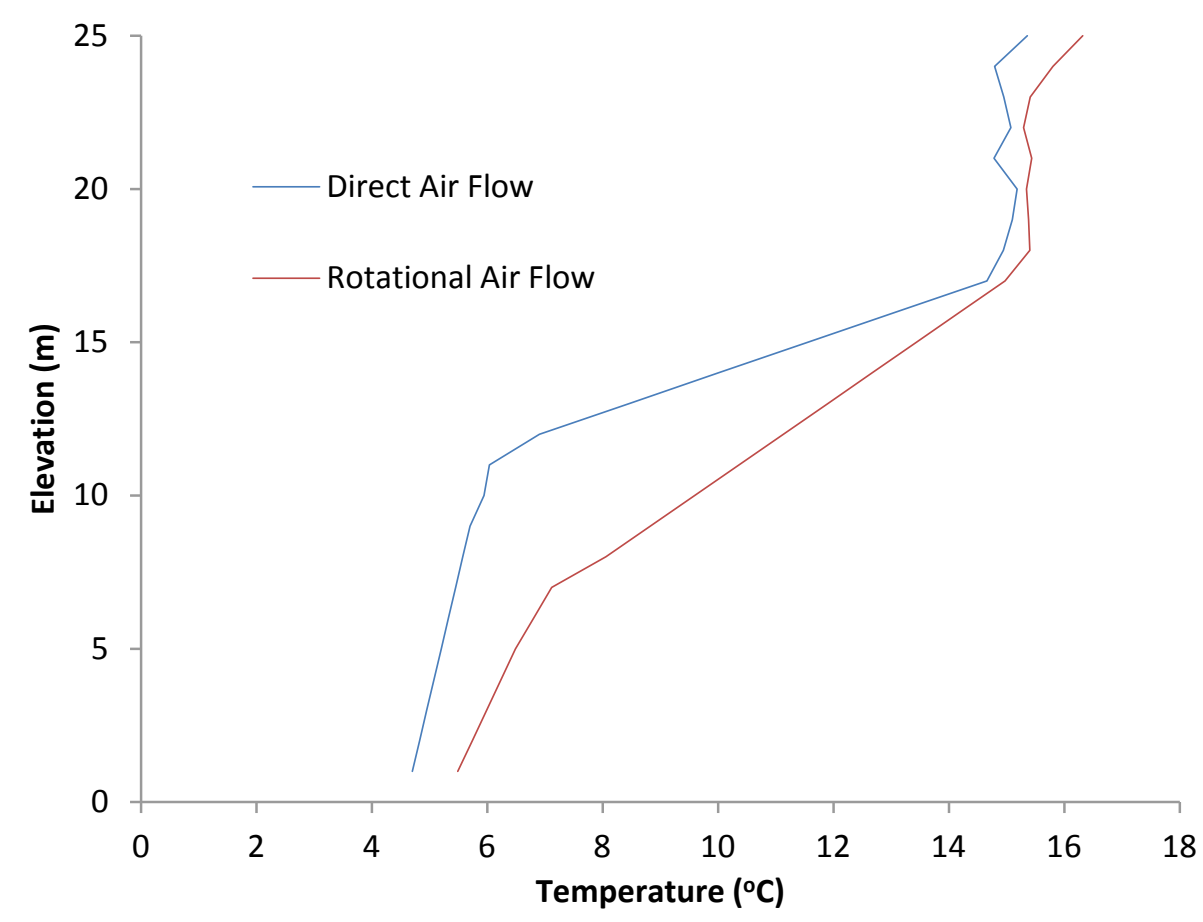

Figure 7-7 Vertical temperature profile for the $1 \mathrm{MW}$ fire test exposed to the $1.5 \mathrm{~m} / \mathrm{s}$ rotational make-up air velocity 


\subsection{3 $2 \mathrm{~m} / \mathrm{s}$ Make-up Air Velocity:}

The steady state condition started at $550 \mathrm{sec}$ for the rotational make-up air test with 2 $\mathrm{m} / \mathrm{s}$ air velocity. The test continued for $950 \mathrm{sec}$ and ended at $1500 \mathrm{sec}$. The ambient temperature was measured at $0^{\circ} \mathrm{C}$ before starting the test. Table 7-3 shows the opening conditions for the rotational make-up air test and the direct air flow test.

Table 7-3 Test characteristics for the $1 \mathrm{MW}$ fire exposed to the $2 \mathrm{~m} / \mathrm{s}$ rotational make-up air velocity

\begin{tabular}{|c|c|c|c|c|c|c|c|}
\hline \multirow[t]{2}{*}{$\begin{array}{l}\text { Opening } \\
\text { arrangement }\end{array}$} & \multirow{2}{*}{$\begin{array}{l}\text { Time } \\
\text { duration } \\
\text { (Sec) }\end{array}$} & \multicolumn{3}{|c|}{ Opening conditions } & \multicolumn{3}{|c|}{$\begin{array}{l}\text { Width (m) } \\
\text { Height (m) }\end{array}$} \\
\hline & & 1 & 2 & 3 & 4 & 5 & 6 \\
\hline \multirow{2}{*}{ Direct Air } & From & 3.00 & 3.60 & 3.60 & 3.40 & \multirow{2}{*}{-} & \multirow[t]{2}{*}{ Fan } \\
\hline & Chapter 6 & 1.37 & 0.57 & 0.57 & 1.21 & & \\
\hline Rotational & \multirow{2}{*}{$550-1500$} & \multirow{2}{*}{ Fan } & \multirow{2}{*}{-} & 3.60 & \multirow{2}{*}{-} & 3.40 & \multirow[t]{2}{*}{ Fan } \\
\hline Make-Up Air & & & & 1.14 & & 1.21 & \\
\hline
\end{tabular}


Figure 7-8 depicts the average temperature profile of direct air flow test and the rotational make-up air test. This figure shows that increasing the make-up air velocity to $2 \mathrm{~m} / \mathrm{s}$ causes a larger change in the temperature profile than for the temperature profile of 1 and $1.5 \mathrm{~m} / \mathrm{s}$ air velocity test.

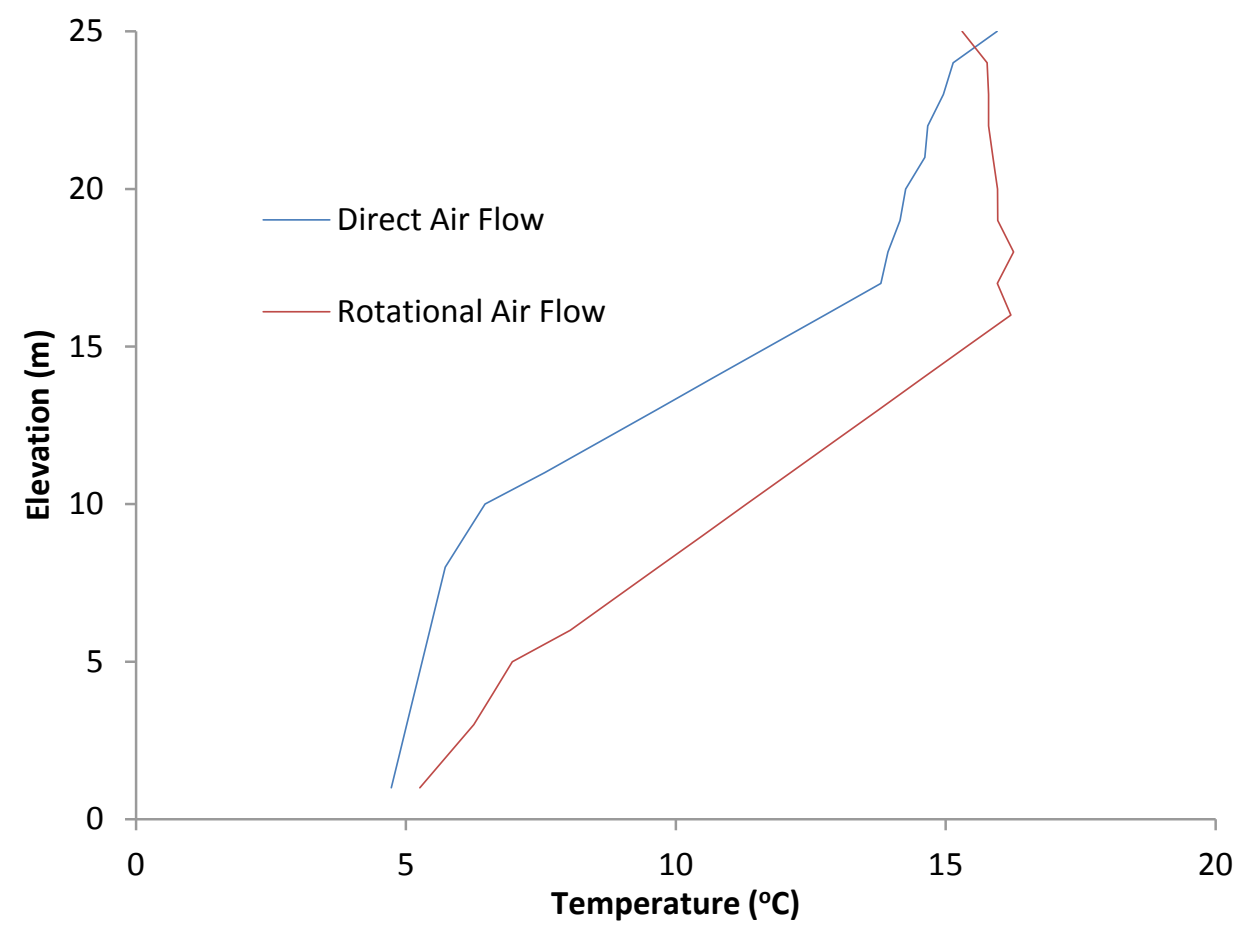

Figure 7-8 Vertical temperature profile for the $1 \mathrm{MW}$ fire test exposed to the $2 \mathrm{~m} / \mathrm{s}$ rotational make-up air velocity 


\subsubsection{Discussion of Experimental Results}

Table 7-4 shows the smoke layer height from the experimental data. This table shows that the rotational make-up air causes a big decrease of the smoke layer height in the atrium. For instance, it decreases from $12.75 \mathrm{~m}$ to $8.76 \mathrm{~m}$ for the $1 \mathrm{~m} / \mathrm{s}$ air velocity test. Also, increasing the rotational make-up air velocity decreases the smoke layer height. For instance, it decreases from $8.76 \mathrm{~m}$ for the $1 \mathrm{~m} / \mathrm{s}$ air velocity test to 5.27 for the 2 $\mathrm{m} / \mathrm{s}$ air velocity test. Also Table 7-4 includes the normalized value of the smoke layer height. The direct airflow test result is used as the reference value. The normalized values are used to find an appropriate reduction factor for the rotational make-up air effect on the smoke layer height. Figure 7-9 shows the smoke interface height in $1 \mathrm{MW}$ fire tests. 
Table 7-4 Smoke layer height in the 1 MW fire test exposed to different air flow directions

\begin{tabular}{|c|c|c|c|c|}
\hline \multicolumn{5}{|c|}{ Smoke layer height from Experiment } \\
\hline $\begin{array}{l}\text { Make-up air } \\
\text { velocity }\end{array}$ & $\begin{array}{l}\text { Air Flow } \\
\text { Direction }\end{array}$ & $\begin{array}{l}\text { Visual } \\
\text { observation } \\
\text { (m) }\end{array}$ & $\begin{array}{l}\text { N-Percentage } \\
\text { Method } \\
\text { (m) }\end{array}$ & $\begin{array}{l}\text { Normalized } \\
\text { Value }\end{array}$ \\
\hline \multirow[b]{2}{*}{$1 \mathrm{~m} / \mathrm{s}$} & Direct Air Flow & 13.0 & 12.75 & 1 \\
\hline & $\begin{array}{l}\text { Rotational Air } \\
\text { Flow }\end{array}$ & 8.5 & 8.76 & 0.69 \\
\hline \multirow[b]{2}{*}{$1.5 \mathrm{~m} / \mathrm{s}$} & Direct Air Flow & 12.0 & 11.91 & 1 \\
\hline & $\begin{array}{l}\text { Rotational Air } \\
\text { Flow }\end{array}$ & 7.5 & 7.57 & 0.63 \\
\hline \multirow[b]{2}{*}{$2 \mathrm{~m} / \mathrm{s}$} & Direct Air Flow & 10.5 & 10.45 & 1 \\
\hline & $\begin{array}{l}\text { Rotational Air } \\
\text { Flow }\end{array}$ & 5.5 & 5.27 & 0.50 \\
\hline
\end{tabular}

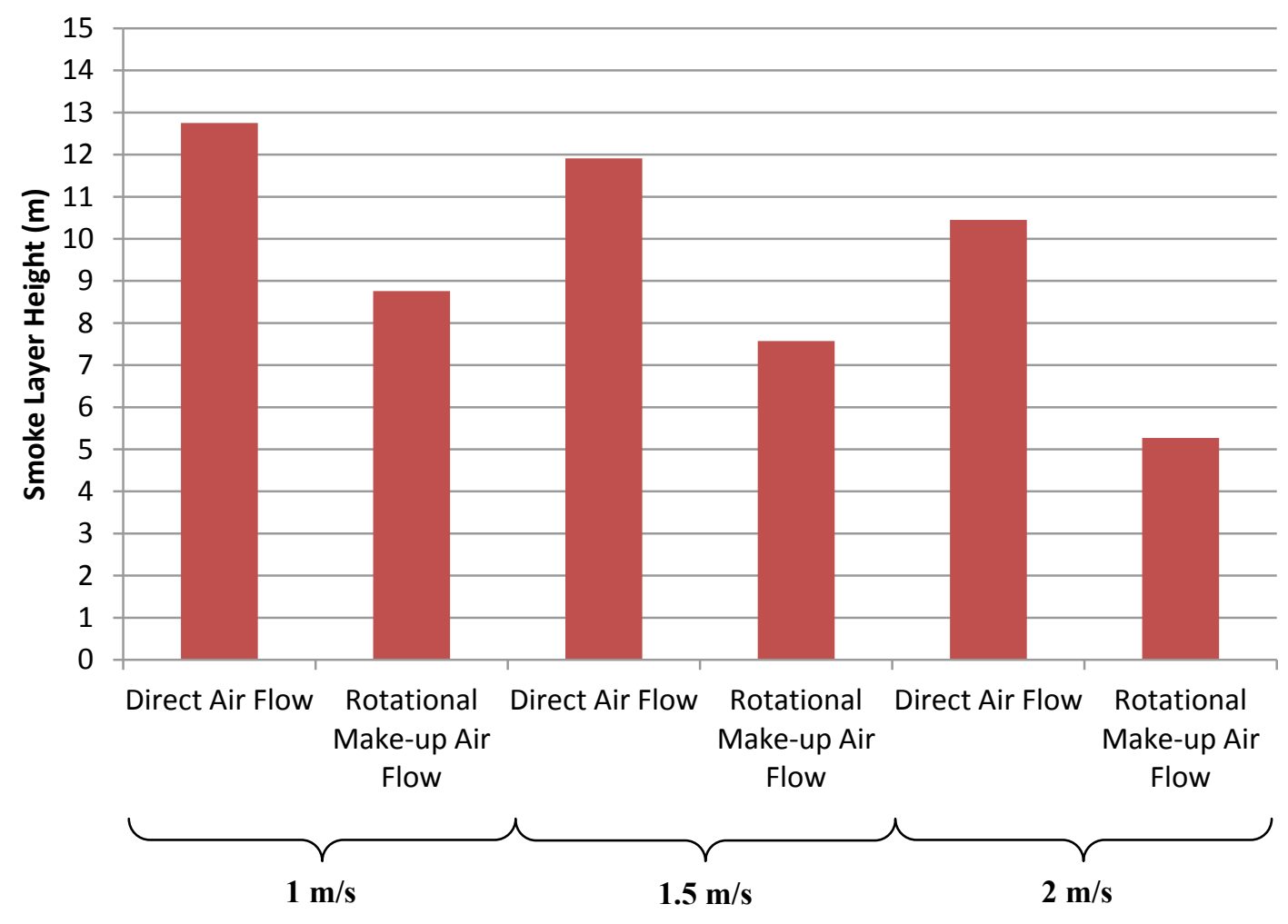

Figure 7-9 Smoke Layer height in the $1 \mathrm{MW}$ fire test exposed to different air flow directions 


\subsubsection{MW Simulation Results}

The fire tests in the atrium have been modelled with FDS5 in order to compare the simulation results with those obtained from full-scale experiments. The simulations considered the effect of rotational make-up air in the atrium. Instead of fan systems, which were used in the experiment, four openings have been located at the four corners of the atrium. Allowing make-up air to enter from the corners of the atrium causes a rotational air flow in the atrium. The exhaust rate and the ambient temperature have been modelled to be the same as in the experiment. A mesh side of $0.26 \times 0.26 \times 0.26 \mathrm{~m}$ was applied to the entire computational domain. The model was run for $600 \mathrm{sec}$ for each case separately to ensure a stable smoke condition was achieved in the atrium. The results of 4-side opening simulation from Chapter 6 were used for the direct air flow smoke layer height. The layer height feature of FDS5 was used to determine the smoke layer height. The layer height feature is based on the Janssens and Tran method. The predicted smoke layer height from CFD modelling and the normalized values are shown in Table 7-5. The smoke layer height is the average of smoke layer heights from four different locations in the atrium during the last $200 \mathrm{sec}$ of each test. The smoke layer height is shown in Figure 7-10. 
Table 7-5 Smoke layer height from CFD modelling of the $1 \mathrm{MW}$ fire test exposed to different air

flow directions

\section{Smoke layer height from CFD modelling}

\begin{tabular}{|c|c|c|c|c|}
\hline $\begin{array}{l}\text { Make-up air } \\
\text { velocity }\end{array}$ & $\begin{array}{l}\text { Air Flow } \\
\text { Direction }\end{array}$ & $\begin{array}{l}\text { Design } \\
\text { (m) }\end{array}$ & $\begin{array}{l}\text { CFD Modeling } \\
\text { (m) }\end{array}$ & $\begin{array}{l}\text { Normalized } \\
\text { Value }\end{array}$ \\
\hline \multirow[b]{2}{*}{$1 \mathrm{~m} / \mathrm{s}$} & Direct Air Flow & 12.93 & 10.91 & 1 \\
\hline & $\begin{array}{l}\text { Rotational Air } \\
\text { Flow }\end{array}$ & 12.93 & 7.35 & 0.67 \\
\hline \multirow[b]{2}{*}{$1.5 \mathrm{~m} / \mathrm{s}$} & Direct Air Flow & 12.93 & 10.41 & 1 \\
\hline & $\begin{array}{l}\text { Rotational Air } \\
\text { Flow }\end{array}$ & 12.93 & 6.12 & 0.58 \\
\hline \multirow[b]{2}{*}{$2 \mathrm{~m} / \mathrm{s}$} & Direct Air Flow & 12.93 & 9.21 & 1 \\
\hline & $\begin{array}{l}\text { Rotational Air } \\
\text { Flow }\end{array}$ & 12.93 & 4.15 & 0.45 \\
\hline
\end{tabular}

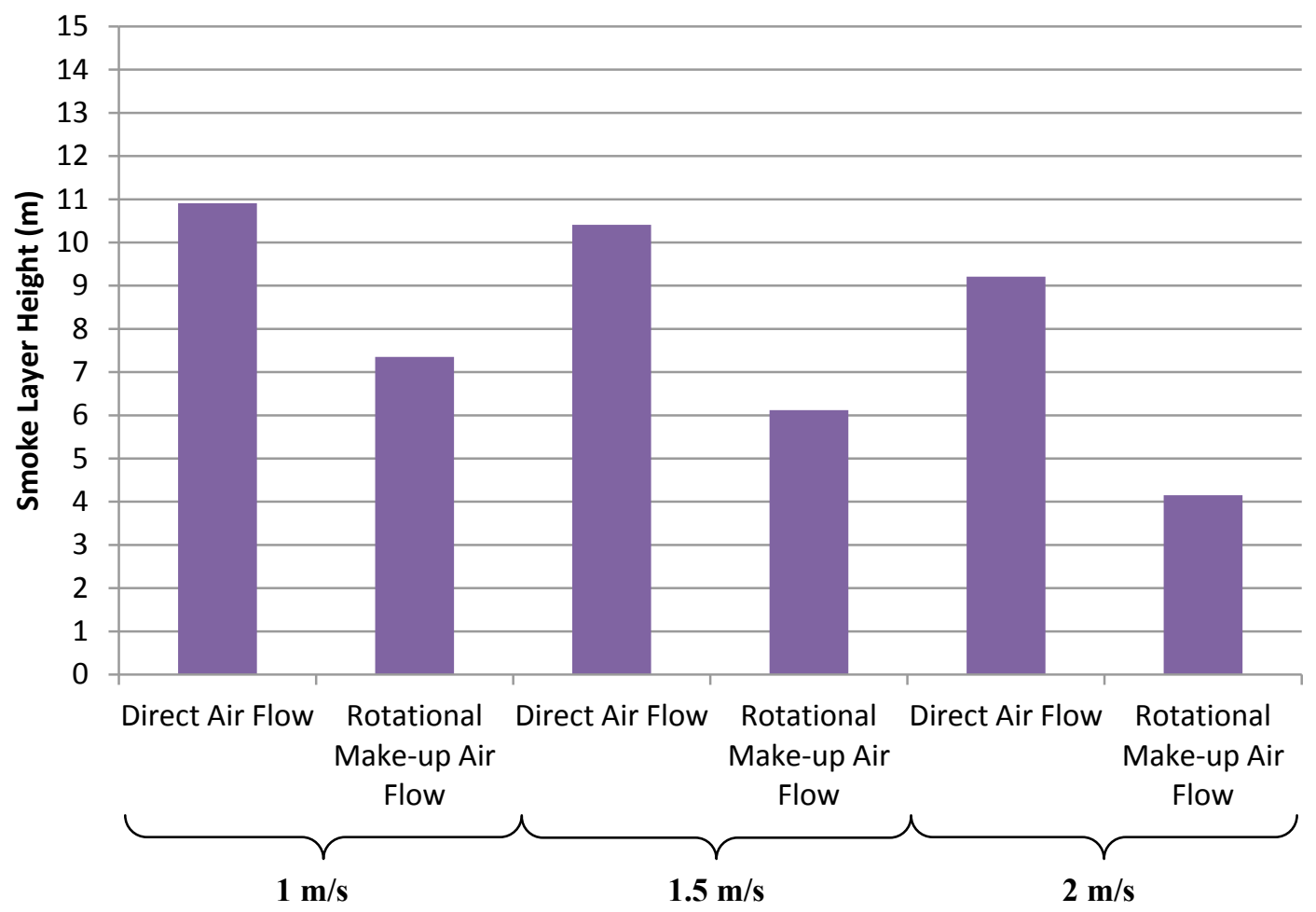

Figure 7-10 Smoke layer height from CFD modelling of the $1 \mathrm{MW}$ fire test exposed to different air flow directions 


\subsection{MW Fire Test}

In this series of tests, the effect of rotational make-up air velocity on the smoke conditions in a $2 \mathrm{MW}$ atrium fire and rotational make-up air velocities of $1,1.5$ and 2 $\mathrm{m} / \mathrm{s}$ was considered. The smoke management systems and the fan system in the atrium were turned on and allowed to work for $10 \mathrm{~min}$ before starting the fire. As with the previous test, the smoke management system was set to $33 \mathrm{~m}^{3} / \mathrm{s}$. The atrium correlations estimate the smoke layer at $11.2 \mathrm{~m}$ from the floor.

\subsection{1 $1 \mathrm{~m} / \mathrm{s}$ Air Velocity}

The smoke condition in the atrium reached stable conditions $450 \mathrm{sec}$ after starting the fire. This test ended at $1450 \mathrm{sec}$ after $1000 \mathrm{sec}$ of steady state conditions. The ambient temperature was at $2^{\circ} \mathrm{C}$ before starting the test. Table 7-6 shows the opening conditions in direct air flow test and the rotational make-up air test.

Table 7-6 Test characteristics for the $2 \mathrm{MW}$ fire exposed to the $1 \mathrm{~m} / \mathrm{s}$ rotational make-up air velocity

\begin{tabular}{|c|c|c|c|c|c|c|c|}
\hline \multirow[t]{2}{*}{$\begin{array}{l}\text { Opening } \\
\text { arrangement }\end{array}$} & \multirow{2}{*}{$\begin{array}{l}\text { Time } \\
\text { duration } \\
\text { (Sec) }\end{array}$} & \multicolumn{3}{|c|}{ Opening conditions } & \multicolumn{3}{|c|}{$\begin{array}{l}\text { Width }(\mathrm{m}) \\
\text { Height }(\mathrm{m})\end{array}$} \\
\hline & & 1 & 2 & 3 & 4 & 5 & 6 \\
\hline \multirow{2}{*}{ Direct Air } & From & 3.00 & 3.60 & 3.60 & 3.40 & \multirow{2}{*}{-} & \multirow[t]{2}{*}{ Fan } \\
\hline & Chapter 6 & 2.75 & 1.14 & 1.14 & 2.43 & & \\
\hline \multirow{2}{*}{$\begin{array}{l}\text { Rotational } \\
\text { Make-Up Air }\end{array}$} & \multirow{2}{*}{$450-1450$} & \multirow{2}{*}{ Fan } & \multirow{2}{*}{-} & 3.60 & \multirow{2}{*}{-} & 3.40 & \multirow[t]{2}{*}{ Fan } \\
\hline & & & & 2.28 & & 2.43 & \\
\hline
\end{tabular}


Figure 7-11 shows the average temperature profile along the atrium height for the rotational make-up air and the direct air flow test. The average temperature profile has been calculated over a $200 \mathrm{sec}$ of the steady state condition. The comparison of temperature profiles shows a big change between the direct air flow profile and the rotational air flow.

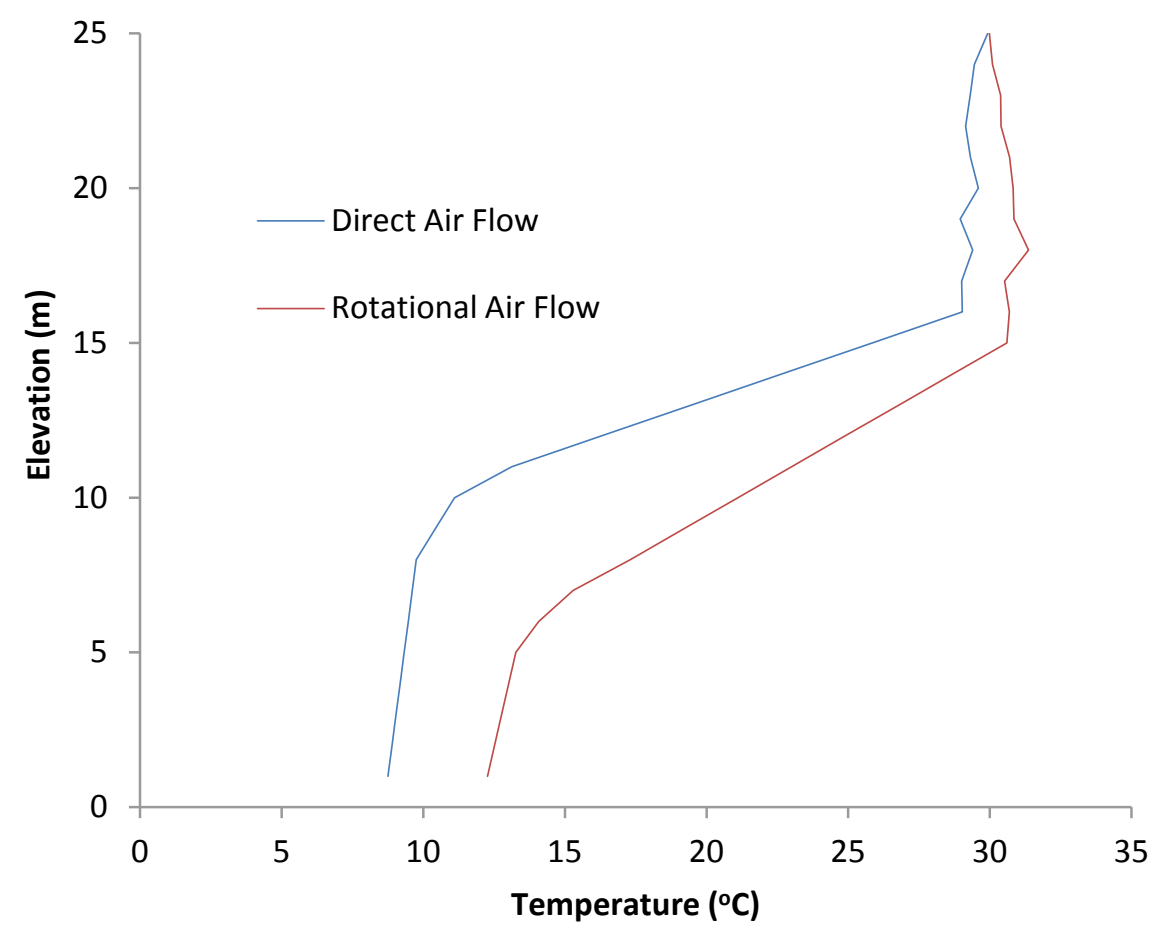

Figure 7-11 Vertical temperature profile for the $2 \mathrm{MW}$ fire test exposed to the $1 \mathrm{~m} / \mathrm{s}$ rotational make-up air velocity 


\subsection{2 $1.5 \mathrm{~m} / \mathrm{s}$ Air Velocity:}

The smoke conditions have been monitored until steady conditions at $550 \mathrm{sec}$. Then, the tests continued for $1000 \mathrm{sec}$ and ended at $1550 \mathrm{sec}$. Table 7-7 shows the test characteristics for the $1.5 \mathrm{~m} / \mathrm{s}$ rotational make-up air test and the direct air flow test. The ambient temperature was at $1{ }^{\circ} \mathrm{C}$ before starting the test.

Table 7-7 Test characteristics for the $2 \mathrm{MW}$ fire exposed to the $1.5 \mathrm{~m} / \mathrm{s}$ rotational make-up air

\begin{tabular}{|c|c|c|c|c|c|c|c|}
\hline \multirow[t]{2}{*}{$\begin{array}{l}\text { Opening } \\
\text { arrangement }\end{array}$} & \multirow{2}{*}{$\begin{array}{l}\text { Time } \\
\text { duration } \\
\text { (Sec) }\end{array}$} & \multicolumn{3}{|c|}{ Opening conditions } & \multicolumn{3}{|c|}{$\begin{array}{l}\text { Width }(\mathrm{m}) \\
\text { Height }(\mathrm{m})\end{array}$} \\
\hline & & 1 & 2 & 3 & 4 & 5 & 6 \\
\hline \multirow{2}{*}{ Direct Air } & From & 3.00 & 3.60 & 3.60 & 3.40 & \multirow{2}{*}{-} & \multirow[t]{2}{*}{ Fan } \\
\hline & Chapter 6 & 1.83 & 0.76 & 0.76 & 1.62 & & \\
\hline Rotational & \multirow{2}{*}{$550-1550$} & \multirow{2}{*}{ Fan } & \multirow{2}{*}{-} & 3.60 & \multirow{2}{*}{-} & 3.40 & \multirow[t]{2}{*}{ Fan } \\
\hline Make-Up Air & & & & 1.52 & & 1.62 & \\
\hline
\end{tabular}


The average temperature profile in the rotational make-up air test and the direct air flow test are shown in Figure 7-12. The average temperature profile has been calculated over the $200 \mathrm{sec}$ of steady state condition. Increasing the air velocity from $1 \mathrm{~m} / \mathrm{s}$ to $1.5 \mathrm{~m} / \mathrm{s}$ causes the transition part of the temperature profile to slightly decent to the lower layer.

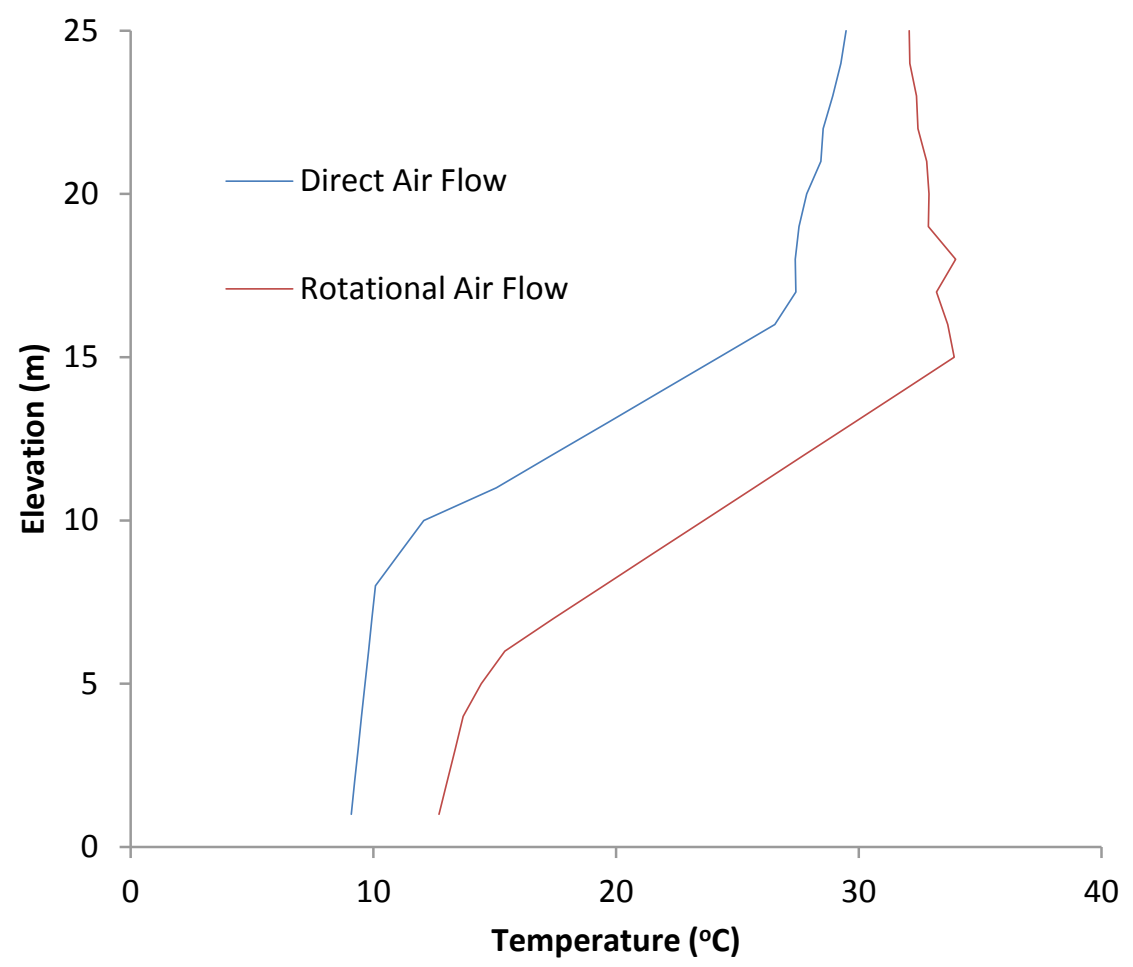

Figure 7-12 Vertical temperature profile for the $2 \mathrm{MW}$ fire test exposed to the $1.5 \mathrm{~m} / \mathrm{s}$ rotational make-up air velocity 


\subsection{3 $2 \mathrm{~m} / \mathrm{s}$ Air Velocity:}

Steady state smoke conditions in the atrium started $600 \mathrm{sec}$ after starting the fire in the atrium. The test ended at $1600 \mathrm{sec}$ after $1000 \mathrm{sec}$ of stable smoke conditions. The ambient temperature was at $3^{\circ} \mathrm{C}$ before starting the fire. Table $7-8$ shows the test characteristics for the rotational make-up air test and the direct air flow test.

Table 7-8 Test characteristics for the $2 \mathrm{MW}$ fire exposed to the $2 \mathrm{~m} / \mathrm{s}$ rotational make-up air

\begin{tabular}{|c|c|c|c|c|c|c|c|}
\hline \multirow[t]{2}{*}{$\begin{array}{l}\text { Opening } \\
\text { arrangement }\end{array}$} & \multirow{2}{*}{$\begin{array}{l}\text { Time } \\
\text { duration } \\
\text { (Sec) }\end{array}$} & \multicolumn{3}{|c|}{ Opening conditions } & \multicolumn{3}{|c|}{$\begin{array}{l}\text { Width (m) } \\
\text { Height (m) }\end{array}$} \\
\hline & & 1 & 2 & 3 & 4 & 5 & 6 \\
\hline \multirow{2}{*}{ Direct Air } & From & 3.00 & 3.60 & 3.60 & 3.40 & \multirow{2}{*}{-} & \multirow[t]{2}{*}{ Fan } \\
\hline & Chapter 6 & 1.37 & 0.57 & 0.57 & 1.21 & & \\
\hline \multirow{2}{*}{$\begin{array}{l}\text { Rotational } \\
\text { Make-Up Air }\end{array}$} & \multirow{2}{*}{$600-1600$} & \multirow{2}{*}{ Fan } & \multirow{2}{*}{-} & 3.60 & \multirow{2}{*}{-} & 3.40 & \multirow[t]{2}{*}{ Fan } \\
\hline & & & & 1.14 & & 1.21 & \\
\hline
\end{tabular}


Figure 7-13 shows the average temperature profile along the atrium height for the direct air flow test and the rotational make-up air test. The average temperature profile is calculated over the $200 \mathrm{sec}$ of the steady condition. As this figure shows, the difference between the temperature profiles of direct air flow and rotational air flow with $2 \mathrm{~m} / \mathrm{s}$ air velocity is more than the difference of the temperature profiles of direct air flow and rotational air flow in the test with 1 and $1.5 \mathrm{~m} / \mathrm{s}$ air velocity.

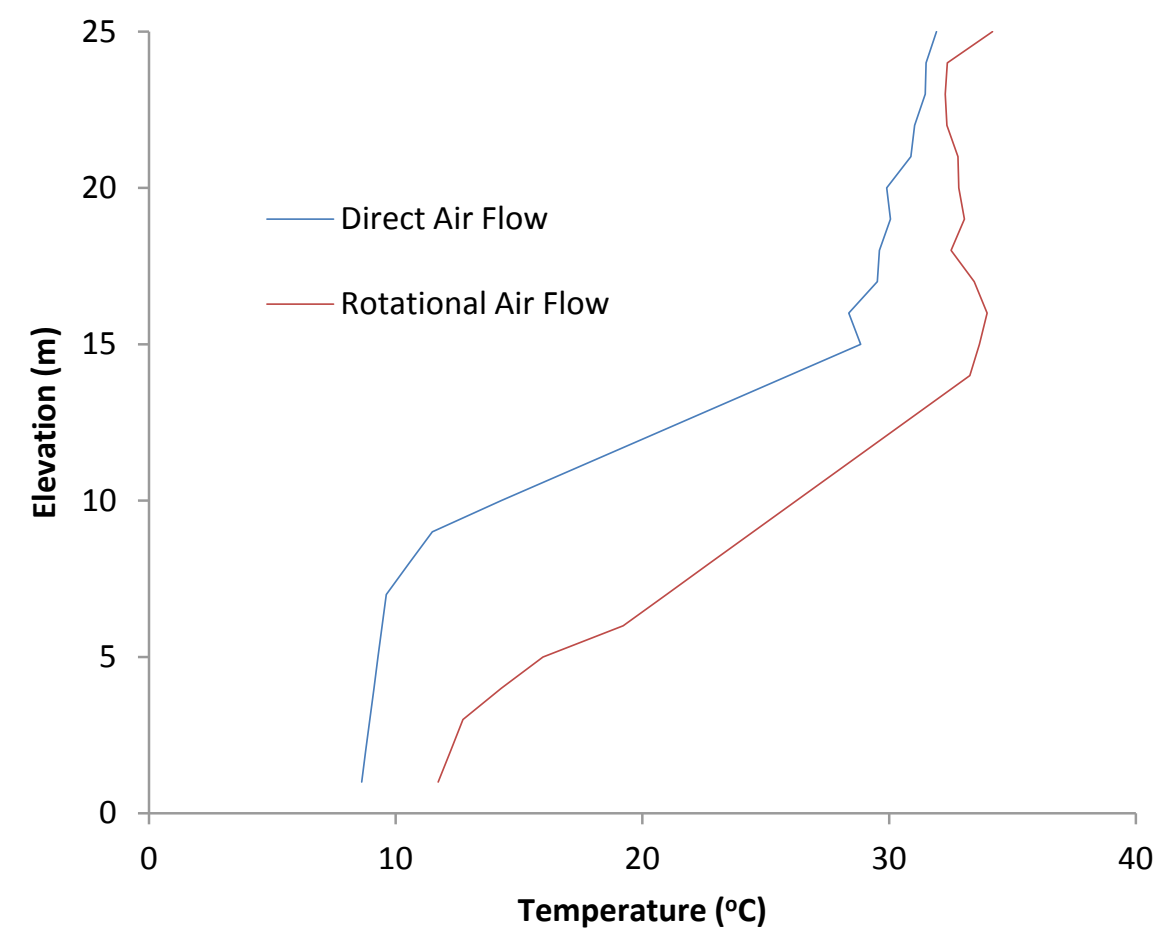

Figure 7-13 Vertical temperature profile for the $2 \mathrm{MW}$ fire test exposed to the $2 \mathrm{~m} / \mathrm{s}$ rotational make-up air velocity 


\subsubsection{Discussion of 2 MW Fire Experimental Results}

The average smoke layer heights in the atrium for the $2 \mathrm{MW}$ fire tests are listed in Table 7-9. This table shows that the rotational make-up air has a big effect on the smoke layer height, as it decreases from $10.93 \mathrm{~m}$ to $7.26 \mathrm{~m}$ for the $1 \mathrm{~m} / \mathrm{s}$ air velocity test. Also, increasing the velocity of the air flow causes the smoke layer height to decrease. For instance, the smoke interface height for the $1 \mathrm{~m} / \mathrm{s}$ air velocity is $7.26 \mathrm{~m}$ and for the $2 \mathrm{~m} / \mathrm{s}$ air velocity is $5.07 \mathrm{~m}$. In addition the normalized values are listed in Table 7-9. The normalized values are used to find a reduction factor that can be applied to the proposed correlation for predicting the smoke layer height. Figure 7-14 shows the smoke layer height in the $2 \mathrm{MW}$ fire tests. 
Table 7-9 Smoke layer height in the $2 \mathrm{MW}$ fire test exposed to different air flow directions

\begin{tabular}{|c|c|c|c|c|}
\hline \multicolumn{5}{|c|}{ Smoke layer height from Experiment } \\
\hline $\begin{array}{l}\text { Make-up air } \\
\text { velocity }\end{array}$ & $\begin{array}{l}\text { Air Flow } \\
\text { Direction }\end{array}$ & $\begin{array}{l}\text { Visual } \\
\text { observation } \\
\text { (m) }\end{array}$ & $\begin{array}{l}\text { N-Percentage } \\
\text { Method } \\
\text { (m) }\end{array}$ & $\begin{array}{l}\text { Normalized } \\
\text { Value }\end{array}$ \\
\hline \multirow[b]{2}{*}{$1 \mathrm{~m} / \mathrm{s}$} & Direct Air Flow & 11.0 & 10.93 & 1 \\
\hline & $\begin{array}{l}\text { Rotational Air } \\
\text { Flow }\end{array}$ & 7.5 & 7.26 & 0.66 \\
\hline \multirow[b]{2}{*}{$1.5 \mathrm{~m} / \mathrm{s}$} & Direct Air Flow & 10.5 & 10.36 & 1 \\
\hline & $\begin{array}{l}\text { Rotational Air } \\
\text { Flow }\end{array}$ & 6.5 & 6.58 & 0.63 \\
\hline \multirow[b]{2}{*}{$2 \mathrm{~m} / \mathrm{s}$} & Direct Air Flow & 9.5 & 9.64 & 1 \\
\hline & $\begin{array}{l}\text { Rotational Air } \\
\text { Flow }\end{array}$ & 5.0 & 5.07 & 0.53 \\
\hline
\end{tabular}

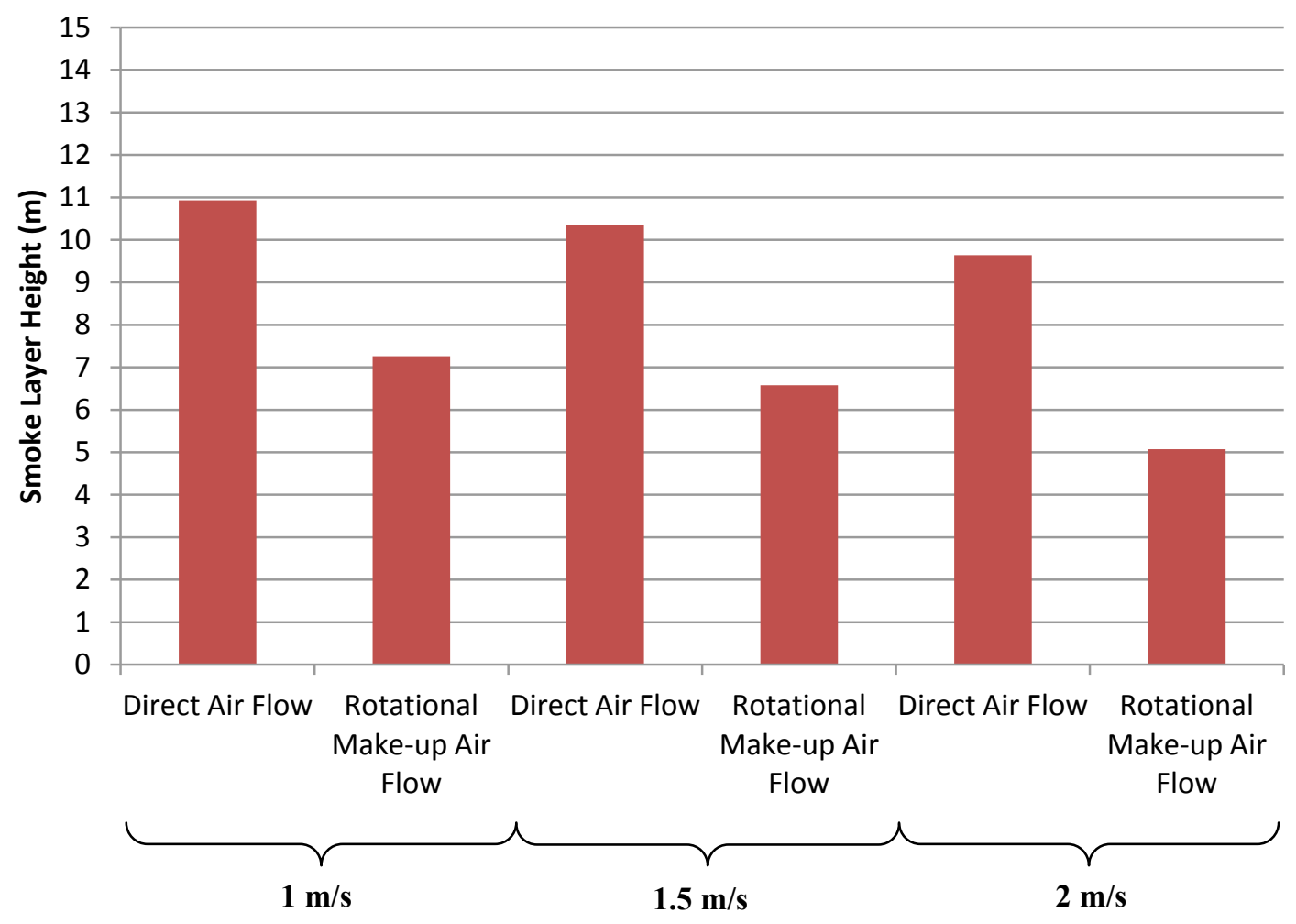

Figure 7-14 Smoke Layer height in the 2 MW fire test exposed to different air flow directions 


\subsubsection{MW Simulation Results}

The model has been set to run for $600 \mathrm{sec}$ for each make-up air velocity separately, and the last $200 \mathrm{sec}$ of simulation have been used to determine the smoke layer height in the atrium. The openings were modelled at the corners of the atrium to provide the rotational make-up air in the atrium. The exhaust rate was set to $33 \mathrm{~m}^{3} / \mathrm{sec}$ same as the test condition. The average of smoke layer height in the atrium is shown in Table 7-10. The smoke layer height is the average of smoke layer height in four different locations in the atrium. The 4-side opening simulation results, which were previously calculated in Chapter 6, were used as the direct air flow results. The modeling results are also shown in Figure 7-15. This figure shows that the decrease in the smoke layer height is larger when the air flow direction changes to rotational air flow. Also, the simulation results agree that increasing the make-up air velocity causes more disturbances in smoke movement and results in lower smoke interface height. 
Table 7-10 Smoke layer height from CFD modelling of the 2 MW fire test exposed to different air

flow directions

\section{Smoke layer height from CFD modelling}

\begin{tabular}{|c|c|c|c|c|}
\hline $\begin{array}{l}\text { Make-up air } \\
\text { velocity }\end{array}$ & $\begin{array}{l}\text { Air Flow } \\
\text { Direction }\end{array}$ & $\begin{array}{l}\text { Design } \\
\text { (m) }\end{array}$ & $\begin{array}{l}\text { CFD Modeling } \\
\text { (m) }\end{array}$ & $\begin{array}{l}\text { Normalized } \\
\text { Value }\end{array}$ \\
\hline \multirow[b]{2}{*}{$1 \mathrm{~m} / \mathrm{s}$} & Direct Air Flow & 11.2 & 9.51 & 1 \\
\hline & $\begin{array}{l}\text { Rotational Air } \\
\text { Flow }\end{array}$ & 11.2 & 6.01 & 0.63 \\
\hline \multirow[b]{2}{*}{$1.5 \mathrm{~m} / \mathrm{s}$} & Direct Air Flow & 11.2 & 9.24 & 1 \\
\hline & $\begin{array}{l}\text { Rotational Air } \\
\text { Flow }\end{array}$ & 11.2 & 5.26 & 0.57 \\
\hline \multirow[b]{2}{*}{$2 \mathrm{~m} / \mathrm{s}$} & Direct Air Flow & 11.2 & 8.61 & 1 \\
\hline & $\begin{array}{l}\text { Rotational Air } \\
\text { Flow }\end{array}$ & 11.2 & 4.06 & 0.47 \\
\hline
\end{tabular}

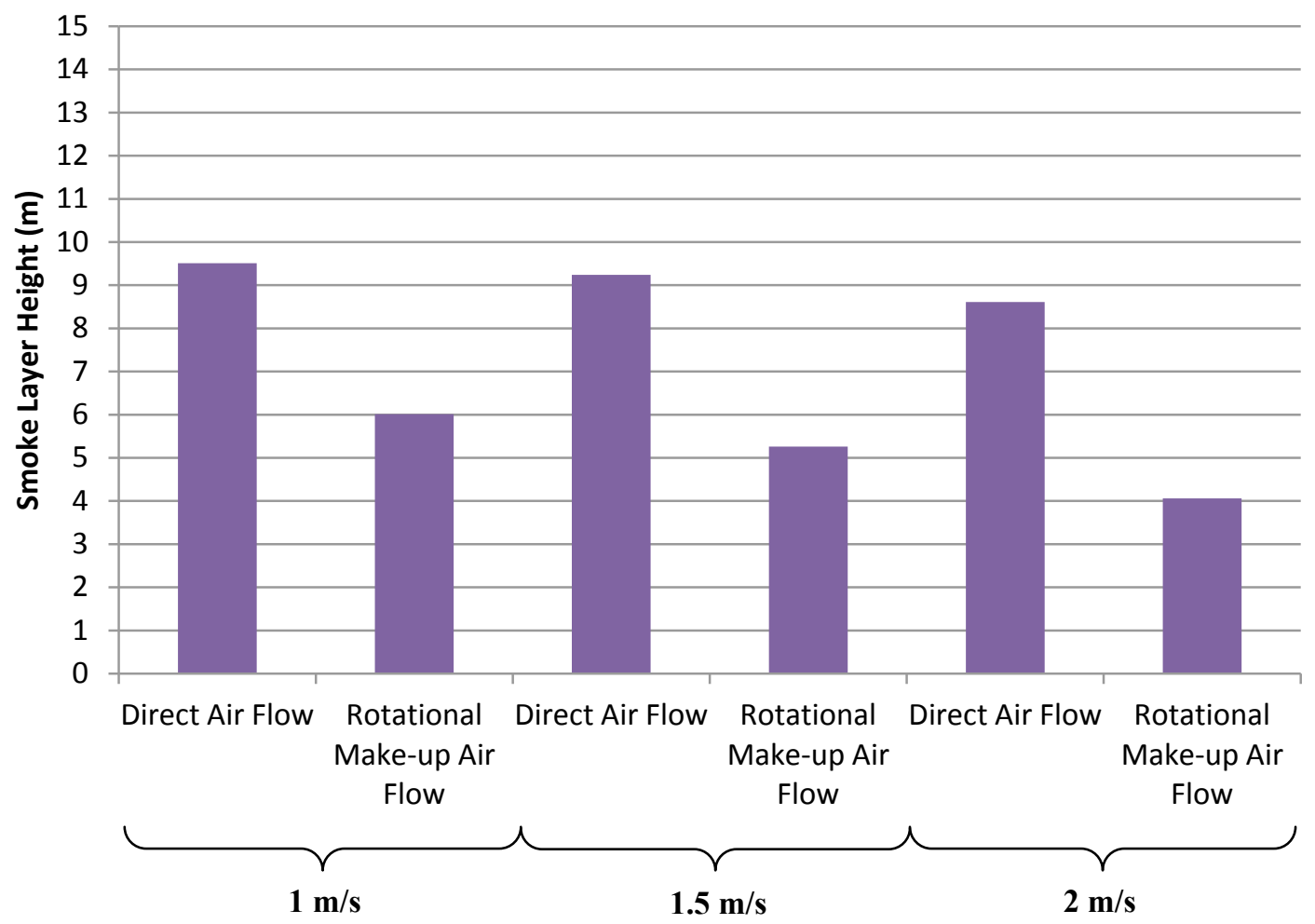

Figure 7-15 Smoke layer height from CFD modelling of the 2 MW fire test exposed to different air flow directions 


\subsection{MW Fire Test}

The effect of rotational air flow with $1,1.5$ and $2 \mathrm{~m} / \mathrm{s}$ air velocity has been studied on the smoke condition for a $5 \mathrm{MW}$ atrium fire. The exhaust system was set to run at 33 $\mathrm{m}^{3} / \mathrm{sec}$ and has been allowed to work for $10 \mathrm{~min}$ before starting the fire. The predicted smoke interface height using the correlations for the $5 \mathrm{MW}$ fire tests is $9 \mathrm{~m}$ from the floor.

\subsection{1 $1 \mathrm{~m} / \mathrm{s}$ Make-up Air Velocity:}

The smoke conditions in the atrium reached stable conditions $500 \mathrm{sec}$ after starting the fire. The test continued for $950 \mathrm{sec}$ and ended at $1450 \mathrm{sec}$. The ambient temperature was measured at $-4^{\circ} \mathrm{C}$ before starting the fire. Table $7-11$ shows the opening condition for the direct air flow and the rotational make-up air test.

Table 7-11 Test characteristics for the $5 \mathrm{MW}$ fire exposed to the $1 \mathrm{~m} / \mathrm{s}$ rotational make-up air

\begin{tabular}{|c|c|c|c|c|c|c|c|}
\hline \multirow[t]{2}{*}{$\begin{array}{l}\text { Opening } \\
\text { arrangement }\end{array}$} & \multirow{2}{*}{$\begin{array}{l}\text { Time } \\
\text { duration } \\
\text { (Sec) }\end{array}$} & \multicolumn{3}{|c|}{ Opening conditions } & \multicolumn{3}{|c|}{$\begin{array}{l}\text { Width (m) } \\
\text { Height (m) }\end{array}$} \\
\hline & & 1 & 2 & 3 & 4 & 5 & 6 \\
\hline \multirow{2}{*}{ Direct Air } & From & 3.00 & 3.60 & 3.60 & 3.40 & \multirow{2}{*}{-} & \multirow[t]{2}{*}{ Fan } \\
\hline & Chapter 6 & 2.75 & 1.14 & 1.14 & 2.43 & & \\
\hline \multirow{2}{*}{$\begin{array}{l}\text { Rotational } \\
\text { Make-Up Air }\end{array}$} & \multirow{2}{*}{$500-1450$} & \multirow{2}{*}{ Fan } & \multirow{2}{*}{-} & 3.60 & \multirow{2}{*}{-} & 3.40 & \multirow[t]{2}{*}{ Fan } \\
\hline & & & & 2.28 & & 2.43 & \\
\hline
\end{tabular}


Figure 7-16 compares the average temperature profiles of the rotational make-up air test with the direct air flow test. The temperature profile is based on the average temperature over the $200 \mathrm{sec}$ of steady conditions in the atrium from the average temperature of the four thermocouple trees. This figure shows that the rotational makeup air causes a considerable change in the smoke interface height even with a $1 \mathrm{~m} / \mathrm{s}$ air velocity.

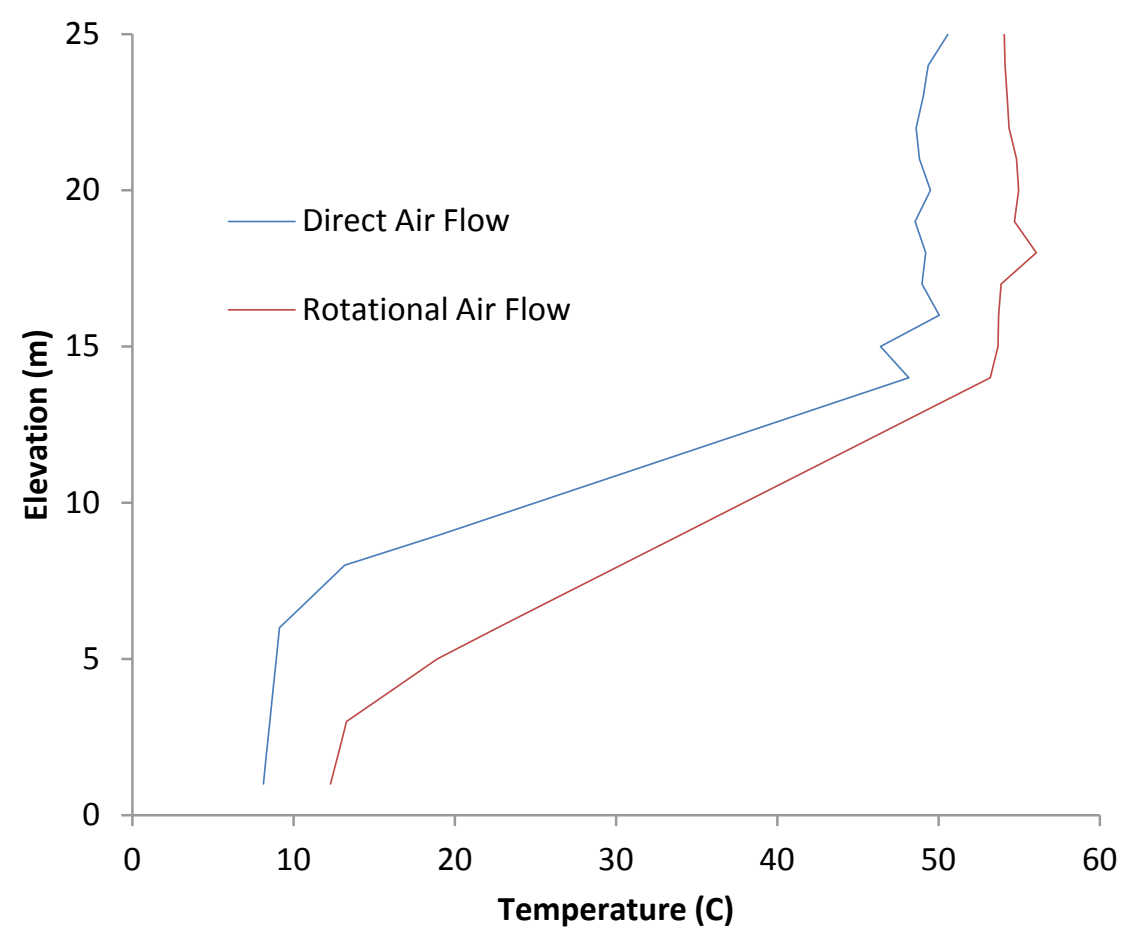

Figure 7-16 Vertical temperature profile for the $5 \mathrm{MW}$ fire test exposed to the $1 \mathrm{~m} / \mathrm{s}$ rotational make-up air velocity 


\subsection{2 $\quad 1.5 \mathrm{~m} / \mathrm{s}$ Make-up Air Velocity}

Stable smoke conditions in the atrium for this test were reached $550 \mathrm{sec}$ after starting the fire. This test ended at $1500 \mathrm{sec}$ after $950 \mathrm{sec}$ of steady state conditions. The ambient temperature was measured at $-2^{\circ} \mathrm{C}$ before starting the test. Table $7-12$ shows the tests characteristics for the direct air flow and the rotational air flow tests.

Table 7-12 Test characteristics for the $5 \mathrm{MW}$ fire exposed to the $1.5 \mathrm{~m} / \mathrm{s}$ rotational make-up air

\begin{tabular}{|c|c|c|c|c|c|c|c|}
\hline \multirow[t]{2}{*}{$\begin{array}{l}\text { Opening } \\
\text { arrangement }\end{array}$} & \multirow{2}{*}{$\begin{array}{l}\text { Time } \\
\text { duration } \\
\text { (Sec) }\end{array}$} & \multicolumn{3}{|c|}{ Opening conditions } & \multicolumn{3}{|c|}{$\begin{array}{l}\text { Width (m) } \\
\text { Height (m) }\end{array}$} \\
\hline & & 1 & 2 & 3 & 4 & 5 & 6 \\
\hline \multirow{2}{*}{ Direct Air } & From & 3.00 & 3.60 & 3.60 & 3.40 & \multirow{2}{*}{-} & \multirow[t]{2}{*}{ Fan } \\
\hline & Chapter 6 & 1.83 & 0.76 & 0.76 & 1.62 & & \\
\hline \multirow{2}{*}{$\begin{array}{l}\text { Rotational } \\
\text { Make-Up Air }\end{array}$} & \multirow{2}{*}{$550-1500$} & \multirow{2}{*}{ Fan } & \multirow{2}{*}{ - } & 3.60 & \multirow{2}{*}{-} & 3.40 & \multirow[t]{2}{*}{ Fan } \\
\hline & & & & 1.52 & & 1.62 & \\
\hline
\end{tabular}


The average temeprature profiles along the atrium height are shown in Figure 7-17 for the direct air flow test and the rotational make-up air test. This figure shows that the diference between the temperature profile of the direct air flow and the temperature profile of the rotational make-up air is considearble.

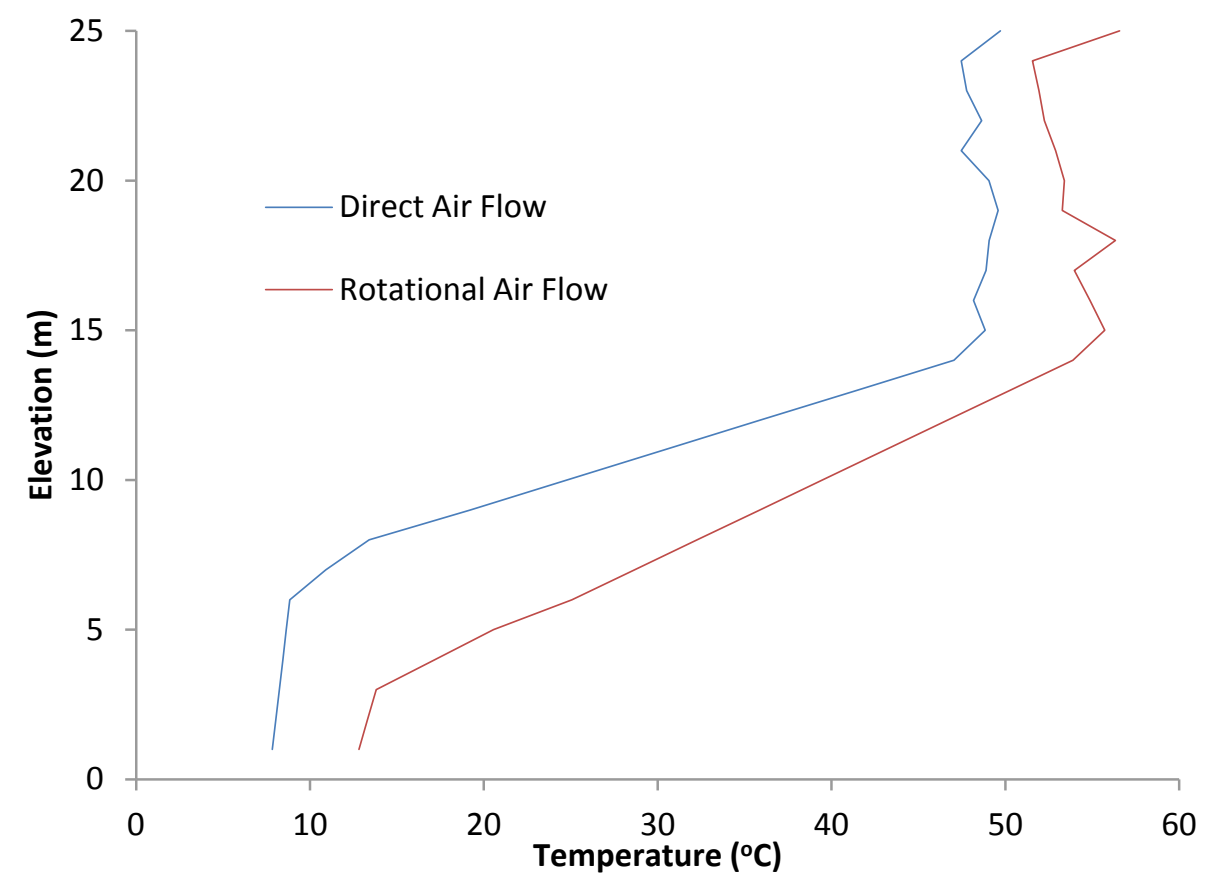

Figure 7-17 Vertical temperature profile for the $5 \mathrm{MW}$ fire test exposed to the $1.5 \mathrm{~m} / \mathrm{s}$ rotational make-up air velocity 


\subsection{3 $2 \mathrm{~m} / \mathrm{s}$ Make-up Air Velocity:}

The smoke conditions have been monitored until steady state conditions occurred at $600 \mathrm{sec}$. The $2 \mathrm{~m} / \mathrm{s}$ rotational make-up air velocity test continued for $950 \mathrm{sec}$ and ended at 1550 sec. Table 7-13 shows the opening conditions for the direct air flow test and the rotational make-up air test. The ambient temperature was at $0^{\circ} \mathrm{C}$ before starting the test.

Table 7-13 Test characteristics for the $5 \mathrm{MW}$ fire exposed to the $2 \mathrm{~m} / \mathrm{s}$ rotational make-up air

\begin{tabular}{|c|c|c|c|c|c|c|c|}
\hline \multicolumn{8}{|c|}{ velocity } \\
\hline \multirow[t]{2}{*}{$\begin{array}{l}\text { Opening } \\
\text { arrangement }\end{array}$} & \multirow{2}{*}{$\begin{array}{l}\text { Time } \\
\text { duration } \\
\text { (Sec) }\end{array}$} & \multicolumn{3}{|c|}{ Opening conditions } & \multicolumn{3}{|c|}{$\begin{array}{l}\text { Width }(m) \\
\text { Height }(m)\end{array}$} \\
\hline & & 1 & 2 & 3 & 4 & 5 & 6 \\
\hline \multirow{2}{*}{ Direct Air } & From & 3.00 & 3.60 & 3.60 & 3.40 & \multirow{2}{*}{ - } & \multirow[t]{2}{*}{ Fan } \\
\hline & Chapter 6 & 1.37 & 0.57 & 0.57 & 1.21 & & \\
\hline Rotational & \multirow{2}{*}{$600-1550$} & \multirow{2}{*}{ Fan } & \multirow[b]{2}{*}{-} & 3.60 & & 3.40 & \multirow[t]{2}{*}{ Fan } \\
\hline Make-Up Air & & & & 1.14 & & 1.21 & \\
\hline
\end{tabular}


A comparison of the average temperature profiles along the atrium height is show in Figure 7-18. As the temperature profile shows, increasing the rotational make-up air velocity causes a decrease in the height of the transition part of the temperature profile, which causes a decrease of the hot layer.

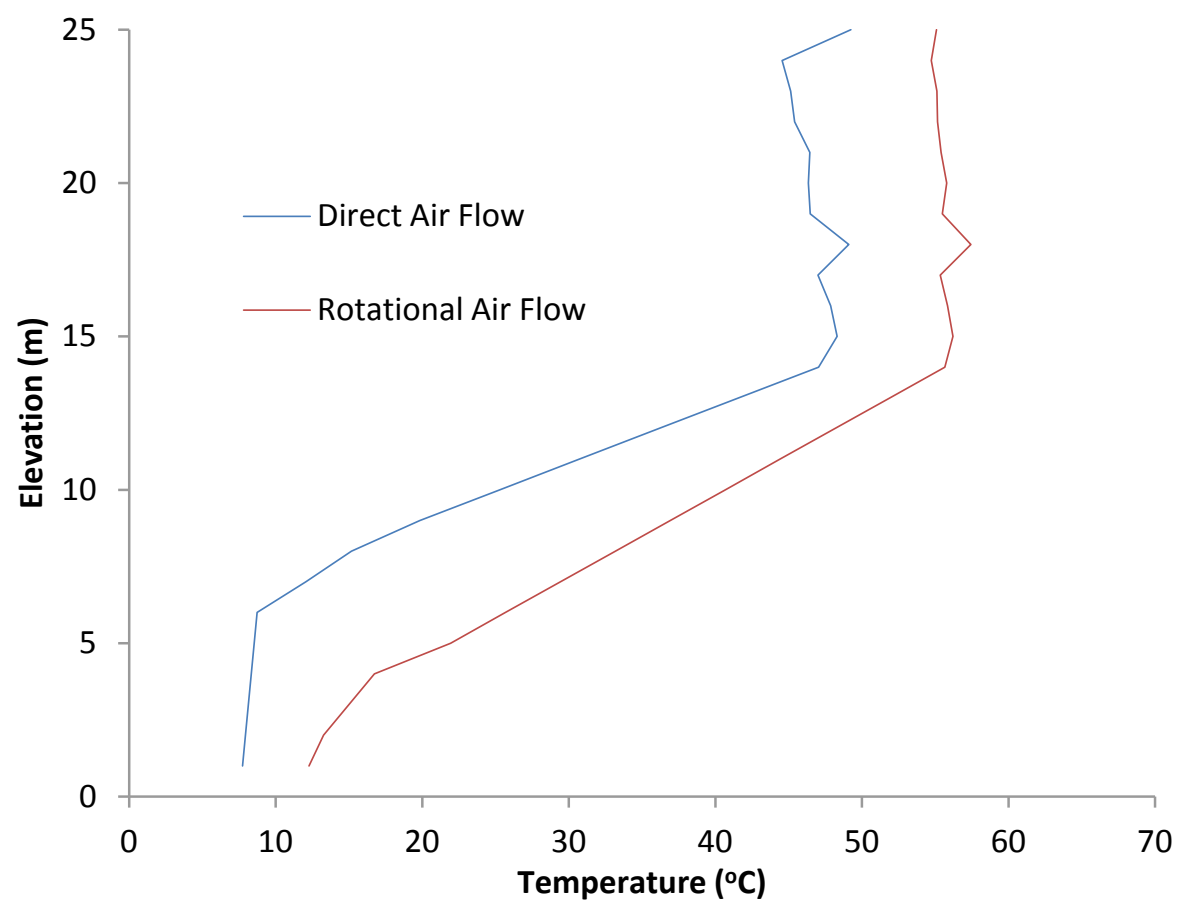

Figure 7-18 Vertical temperature profile for the $5 \mathrm{MW}$ fire test exposed to the $2 \mathrm{~m} / \mathrm{s}$ rotational make-up air velocity 


\subsubsection{Discussion of 5 MW Fire Test Results}

Table 7-14 shows the smoke layer height of the $5 \mathrm{MW}$ atrium fire tests exposed to 1 , 1.5 and $2 \mathrm{~m} / \mathrm{s}$ air velocities. A comparison between the direct air flow and the rotational air flow results shows that the rotational air flow causes a big decrease of the smoke layer height. For instance, the smoke layer heigt drops from $8.57 \mathrm{~m}$ to $5.46 \mathrm{~m}$ in the 1 $\mathrm{m} / \mathrm{s}$ air velocity test. Also, the normalized values for the smoke interface heights are listed in Table 7-14. Although the normalized value shows the smoke layer height decrease with increasing the make-up air velocity, the reduction rate is less than the reduction rate in the 1 and $2 \mathrm{MW}$ fire tests. This might be because of the less effect of air velocities on the plume and smoke conditions in big fires than in small fires. Figure 7-19 shows the smoke layer height of the $5 \mathrm{MW}$ fire tests. 
Table 7-14 Smoke layer height in the $5 \mathrm{MW}$ fire test exposed to different air flow directions

\begin{tabular}{|c|c|c|c|c|}
\hline \multicolumn{5}{|c|}{ Smoke layer height from Experiment } \\
\hline $\begin{array}{l}\text { Make-up air } \\
\text { velocity }\end{array}$ & $\begin{array}{l}\text { Air Flow } \\
\text { Direction }\end{array}$ & $\begin{array}{l}\text { Visual } \\
\text { observation } \\
\text { (m) }\end{array}$ & $\begin{array}{l}\text { N-Percentage } \\
\text { Method } \\
\text { (m) }\end{array}$ & $\begin{array}{l}\text { Normalized } \\
\text { Value }\end{array}$ \\
\hline \multirow[b]{2}{*}{$1 \mathrm{~m} / \mathrm{s}$} & Direct Air Flow & 8.5 & 8.57 & 1 \\
\hline & $\begin{array}{l}\text { Rotational Air } \\
\text { Flow }\end{array}$ & 5.5 & 5.46 & 0.63 \\
\hline \multirow[b]{2}{*}{$1.5 \mathrm{~m} / \mathrm{s}$} & Direct Air Flow & 8.5 & 8.48 & 1 \\
\hline & $\begin{array}{l}\text { Rotational Air } \\
\text { Flow }\end{array}$ & 5.5 & 5.22 & 0.61 \\
\hline \multirow[b]{2}{*}{$2 \mathrm{~m} / \mathrm{s}$} & Direct Air Flow & 8 & 8.18 & 1 \\
\hline & $\begin{array}{l}\text { Rotational Air } \\
\text { Flow }\end{array}$ & 5.0 & 4.78 & 0.58 \\
\hline
\end{tabular}

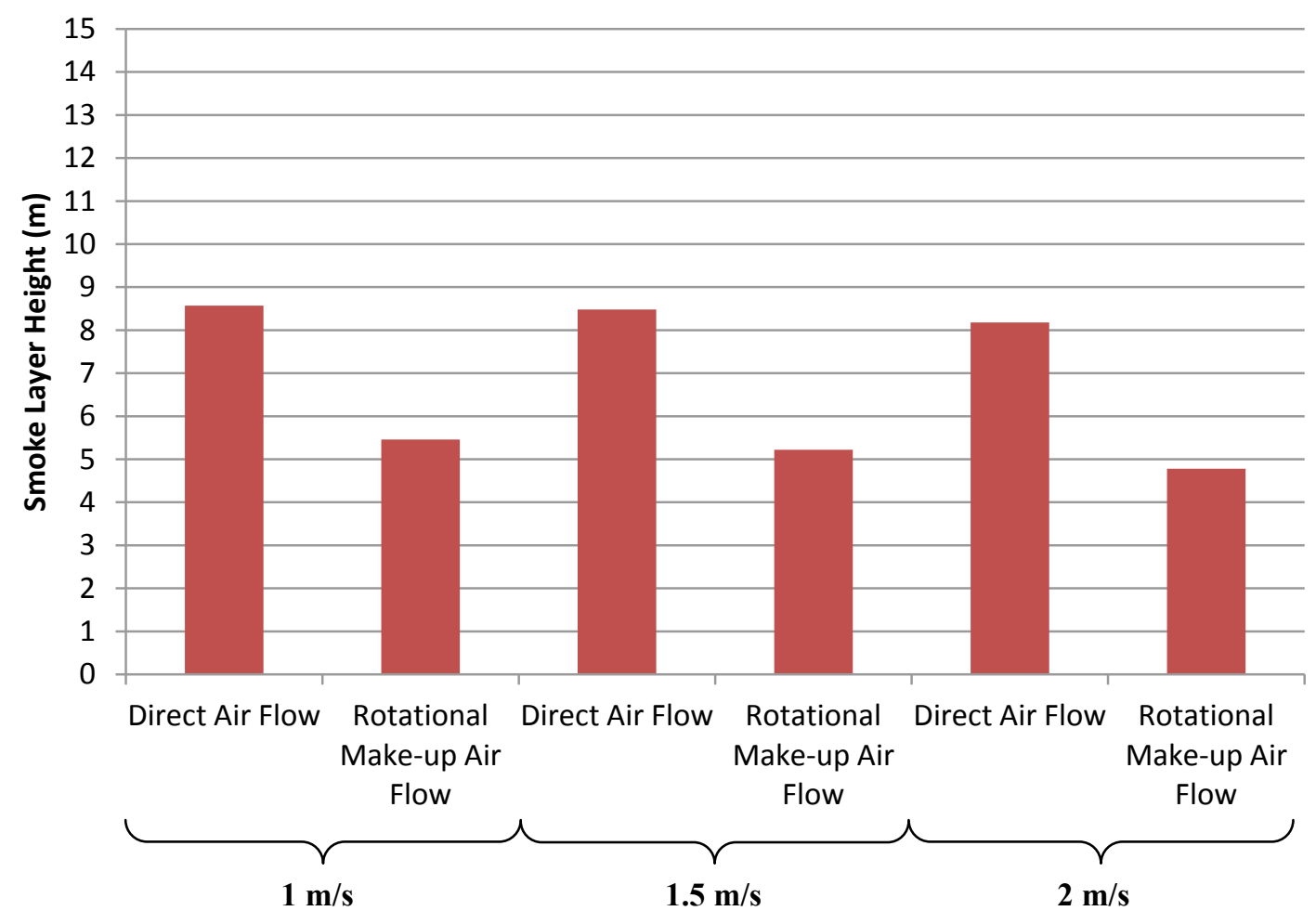

Figure 7-19 Smoke layer height in the $5 \mathrm{MW}$ fire test exposed to different air flow directions 


\subsubsection{MW Simulation Results}

Table 7-15 shows the smoke layer heights and the normalized values from the CFD modelling of the $5 \mathrm{MW}$ fire tests. The smoke layer height is the average of the four layer height detectors in the atrium. The rotational make-up air modelling with $1,1.5$ and $2 \mathrm{~m} / \mathrm{s}$ air velocity has been modeled separately, and the simulation was set to run for $600 \mathrm{sec}$ to ensure steady state conditions. The results of the last $200 \mathrm{sec}$ of modelling were used to calculate the average smoke layer height. The smoke layer height of the direct air flow is obtained from the results of the 4-side opening from Chapter 6. The normalized values are also listed in Table 7-15. Based on the normalized values, increasing the make-up air velocity does not make a big effect on the smoke layer height in the $5 \mathrm{MW}$ fire, as it is 0.59 for $1 \mathrm{~m} / \mathrm{s}$ air velocity and its 0.54 for $2 \mathrm{~m} / \mathrm{s}$ air velocity, however; a comparison between the smoke layer height from direct air flow and the rotational air flow shows that the rotational make-up air decreases the smoke layer height from $7.42 \mathrm{~m}$ to $4.41 \mathrm{~m}$ for the $1 \mathrm{~m} / \mathrm{s}$ air velocity test and decreases from $6.71 \mathrm{~m}$ to $3.62 \mathrm{~m}$ for the $2 \mathrm{~m} / \mathrm{s}$ air velocity test. The smoke layer heights from the CFD modelling of $5 \mathrm{MW}$ fire are shown in Figure 7-20. 
Table 7-15 Smoke layer height from CFD modelling of the $5 \mathrm{MW}$ fire test exposed to different air

flow directions

\section{Smoke layer height from CFD modelling}

\begin{tabular}{|c|c|c|c|c|}
\hline $\begin{array}{l}\text { Make-up air } \\
\text { velocity }\end{array}$ & $\begin{array}{l}\text { Air Flow } \\
\text { Direction }\end{array}$ & $\begin{array}{l}\text { Design } \\
\text { (m) }\end{array}$ & $\begin{array}{l}\text { CFD Modeling } \\
\text { (m) }\end{array}$ & $\begin{array}{l}\text { Normalized } \\
\text { Value }\end{array}$ \\
\hline \multirow[b]{2}{*}{$1 \mathrm{~m} / \mathrm{s}$} & Direct Air Flow & 9 & 7.42 & 1 \\
\hline & $\begin{array}{l}\text { Rotational Air } \\
\text { Flow }\end{array}$ & 9 & 4.41 & 0.59 \\
\hline \multirow[b]{2}{*}{$1.5 \mathrm{~m} / \mathrm{s}$} & Direct Air Flow & 9 & 7.11 & 1 \\
\hline & $\begin{array}{l}\text { Rotational Air } \\
\text { Flow }\end{array}$ & 9 & 4.15 & 0.58 \\
\hline \multirow[b]{2}{*}{$2 \mathrm{~m} / \mathrm{s}$} & Direct Air Flow & 9 & 6.71 & 1 \\
\hline & $\begin{array}{l}\text { Rotational Air } \\
\text { Flow }\end{array}$ & 9 & 3.62 & 0.54 \\
\hline
\end{tabular}

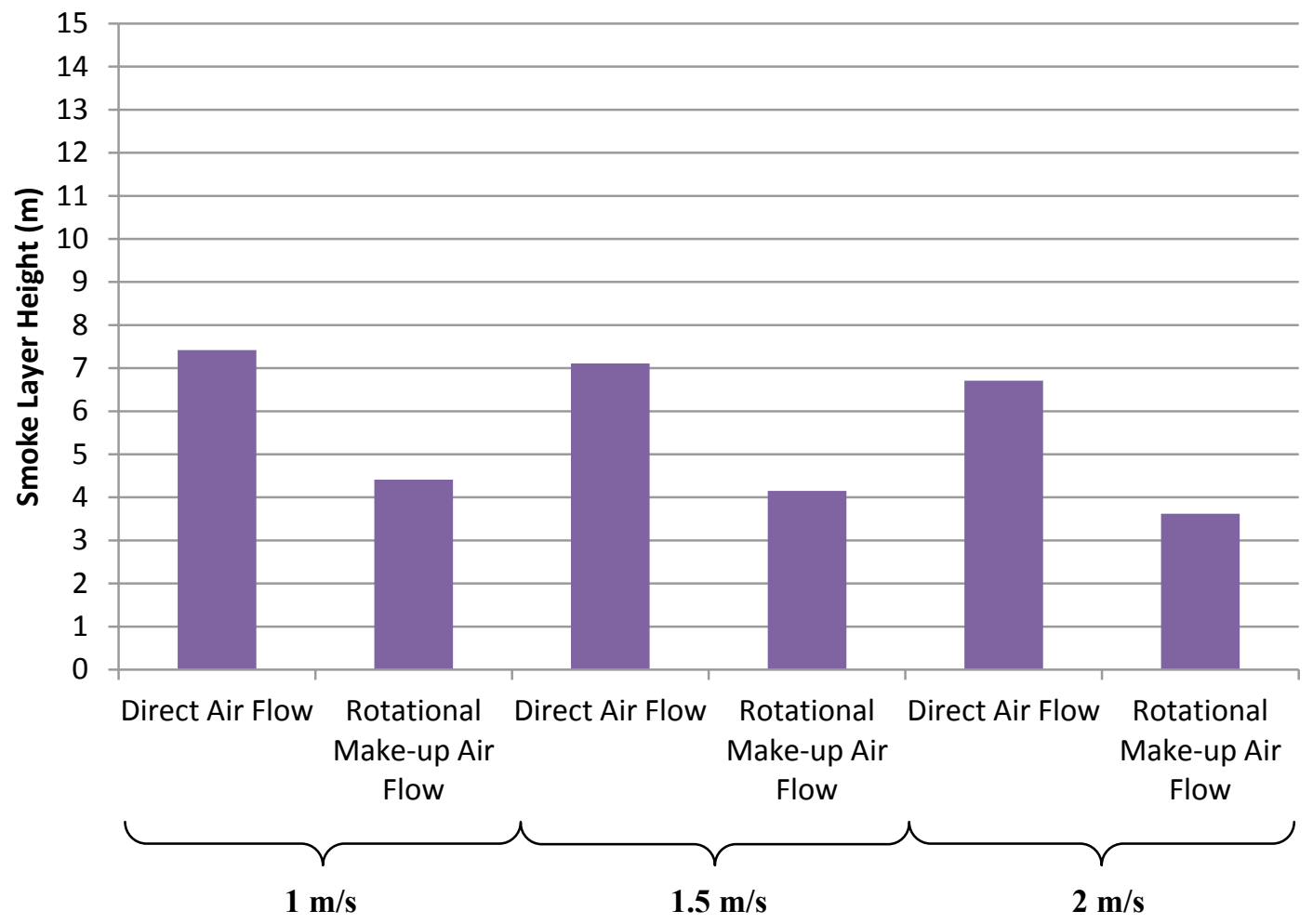

Figure 7-20 Smoke layer height from CFD modelling of the $5 \mathrm{MW}$ fire test exposed to different air

flow directions 


\subsection{Conclusion}

In this chapter the effect of rotational make-up air on the smoke conditions in the atrium has been discussed. Locating the openings in the corners of the atrium causes rotational make-up air. The results of rotational make-up air with velocities of $1,1.5$ and $2 \mathrm{~m} / \mathrm{s}$ and fire sizes of $1 \mathrm{MW}$ to $2 \mathrm{MW}$ and $5 \mathrm{MW}$ have been compared with the results of direct air flow. Figures 7-21 to 7-23 show the results of direct air flow and rotational make-up air tests from different methods.

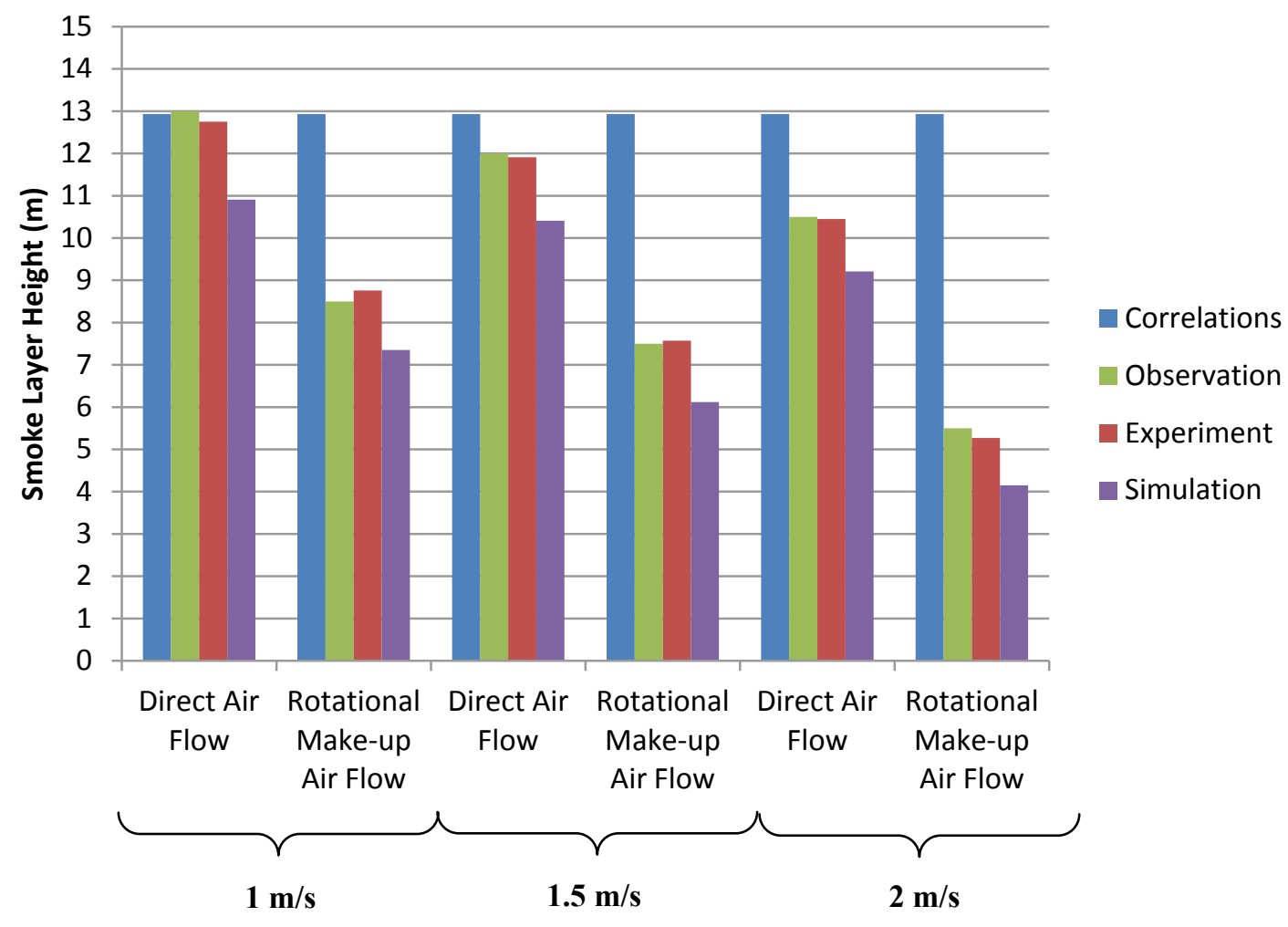

Figure 7-21 Comparison of smoke layer height for the $1 \mathrm{MW}$ fire 


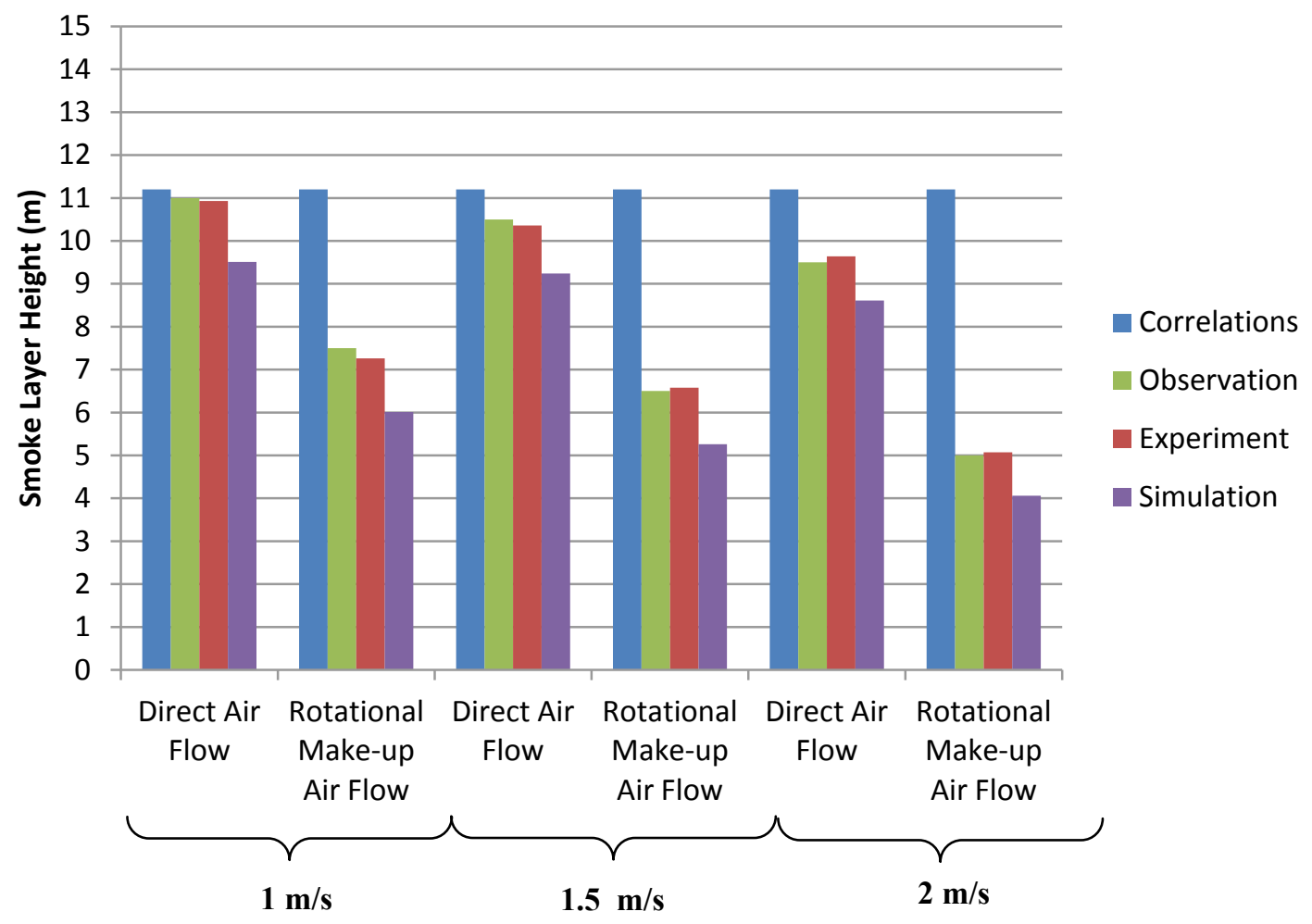

Figure 7-22 Comparison of smoke layer height for the 2 MW fire

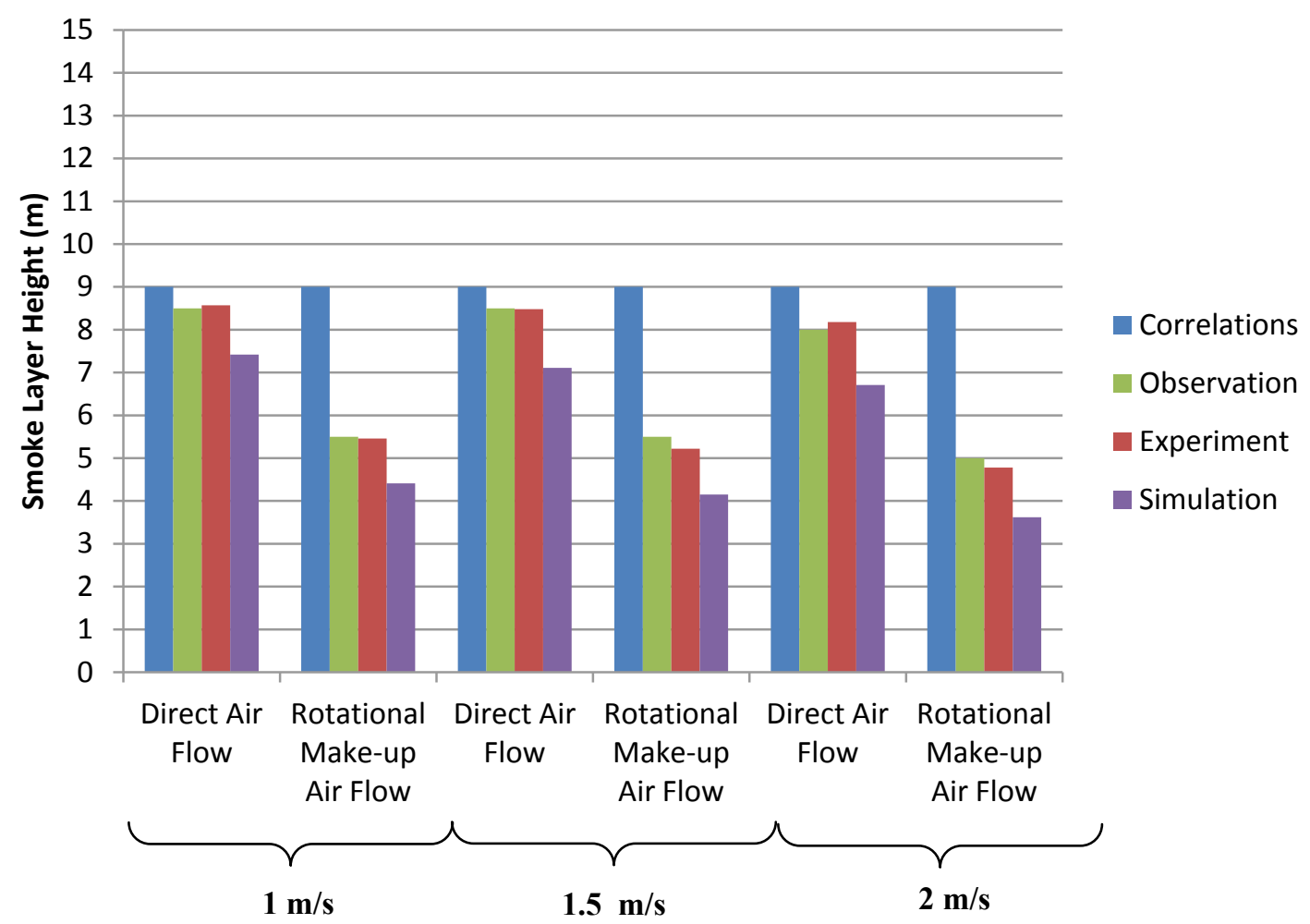

Figure 7-23 Comparison of smoke layer height for the $5 \mathrm{MW}$ fire 
The experimental data and simulation results show that the rotational make-up air decreases the smoke layer height considerably. Also, increasing the rotational make-up air velocity causes more turbulence in the smoke conditions and decreases the smoke interface height.

A comparison of the normalized smoke layer height from the experimental data and the CFD modelling results agree that in most cases the smoke layer height in rotational make-up air test decreases to $55 \%-65 \%$ of the value of the smoke layer height in the direct air flow.

Experimental data and CFD modeling results agree that increasing the make-up air velocity causes a lower ratio of decrease in the smoke layer height of big fires compared to the ratio of decrease in smoke layer height in small fires.

This result is consistent with the results of Kerber and Milke (2007) indicating that the rotational make-up air decreases the smoke layer height considerably. They reported a major turbulence and a large decrease in the smoke interface height, as they considered corner openings which were located along the atrium height and a make-up air velocity that was set to $2 \mathrm{~m} / \mathrm{s}$. These opening arrangements are considered to be the worst case scenario, as the make-up air is allowed to enter the smoke layer and decrease the smoke layer height. 
Although locating openings at the corners of the atrium is strongly not recommended, in case of architectural design restrictions, it is recommended to decrease the proposed reduction factor correlation by an extra factor to ensure that people are not affected by the smoke.

$$
R F=f_{r} f_{a}\left(\frac{1}{2.688 \dot{Q}_{c}^{\frac{1}{2}}} V^{3}-\frac{1}{1.2 \dot{Q}_{c}^{\frac{1}{3}}} V^{2}+\frac{1}{120} V+1\right)
$$

$f_{r}$ is the rotational make-up air factor and is equal to:

$$
f_{r}=\left\{\begin{array}{lr}
1 & \text { direct make }- \text { up air } \\
& \\
-0.26 V+1 & \text { rotational make - up air }
\end{array}\right.
$$

A comparison of the smoke layer height predicted by existing correlations, smoke layer height adjusted by the reduction factor correlation for the rotational make-up air, the experimental results and the simulation estimations are shown in Figures 6-24 to 6-26. 


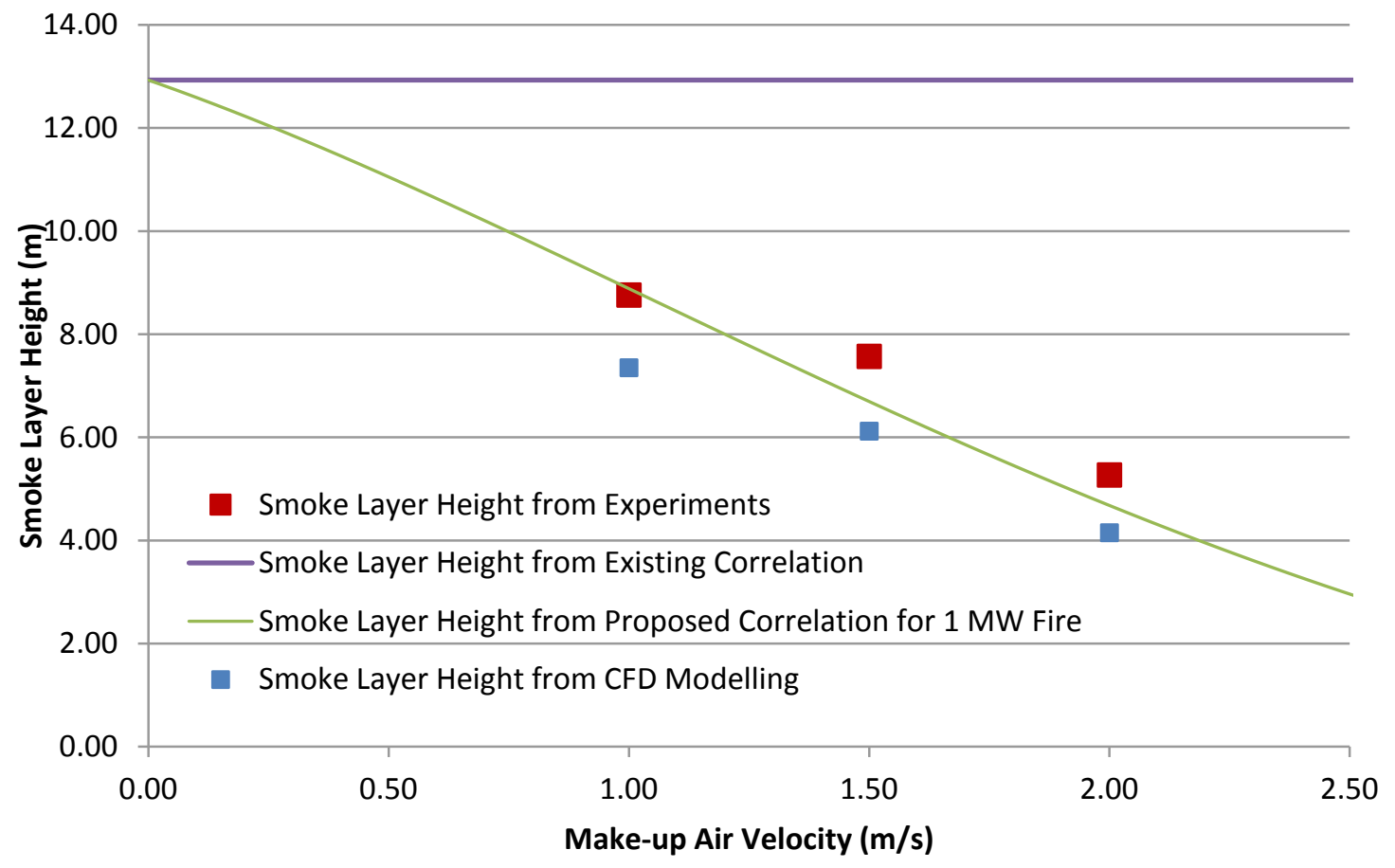

Figure 7-24 Proposed reduction factor correlation for the 1 MW fire exposed to rotational make-up air

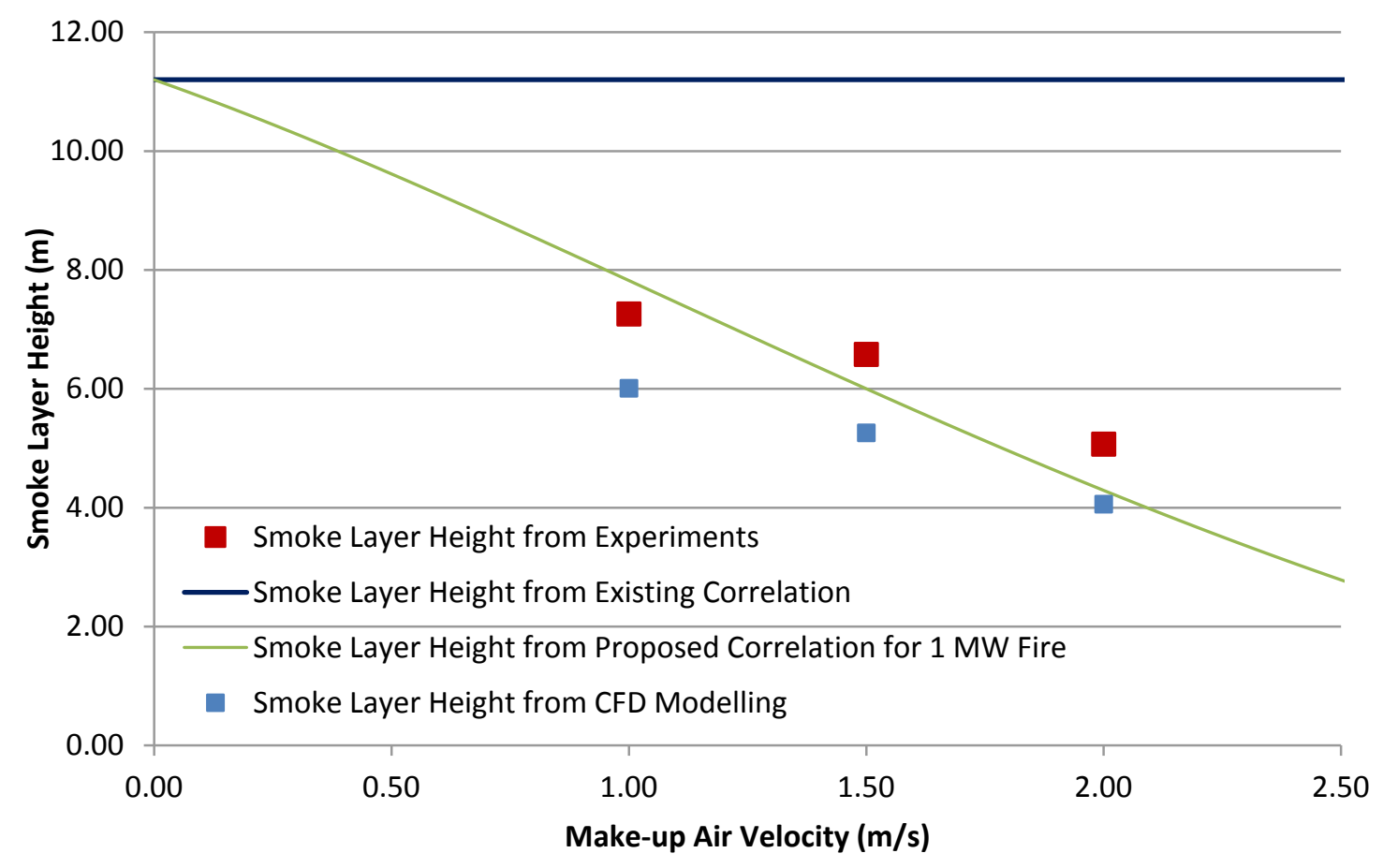

Figure 7-25 Proposed reduction factor correlation for the $2 \mathrm{MW}$ fire exposed to rotational make-up air 


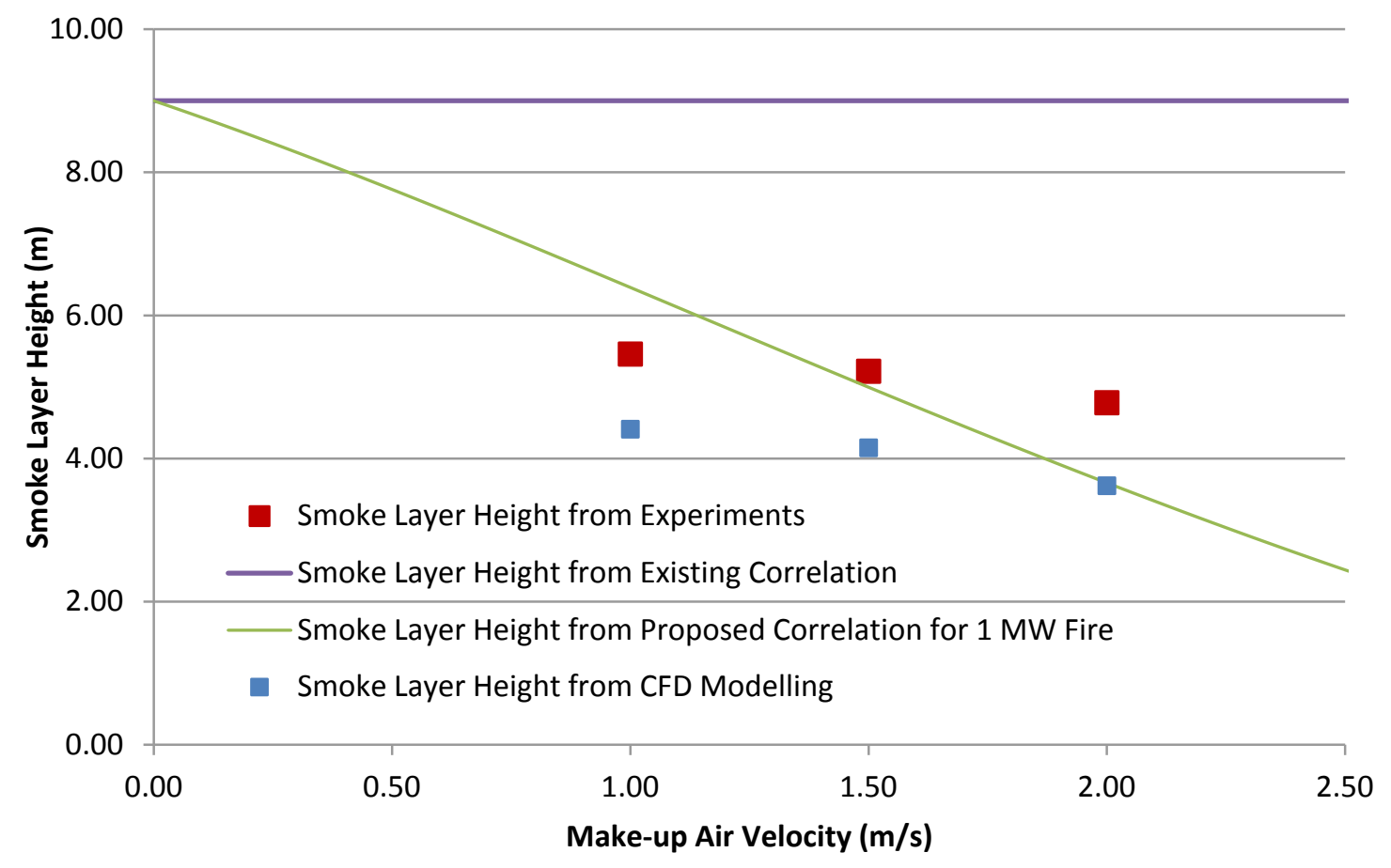

Figure 7-26 Proposed reduction factor correlation for the $5 \mathrm{MW}$ fire exposed to rotational make-up air

Table 7-16 shows the standard error of the proposed correlation in the case of rotational make-up air in the atrium. The standard error shows a good agreement between the results of the full-scale tests and the estimate of the proposed correlation. Also, the table shows that the standard error increases with increasing the fire size in the case of rotational air flow. 
Table 7-16 Standard error of the proposed correlation in the case of rotational air flow

\begin{tabular}{|c|c|c|c|c|c|}
\hline $\begin{array}{l}\text { Air flow } \\
\text { direction }\end{array}$ & Fire size & $\begin{array}{l}\text { Make-up air } \\
\text { velocity }\end{array}$ & $\begin{array}{l}\text { Smoke layer } \\
\text { height from } \\
\text { experiment } \\
\text { (m) }\end{array}$ & $\begin{array}{l}\text { Smoke layer } \\
\text { height from } \\
\text { proposed } \\
\text { correlation } \\
\text { (m) }\end{array}$ & $\begin{array}{l}\text { Standard } \\
\text { error } \\
\left(\sigma_{\text {est }}\right)\end{array}$ \\
\hline \multirow{3}{*}{$\begin{array}{l}\text { Rotational air } \\
\text { flow }\end{array}$} & \multirow{3}{*}{$1 \mathrm{MW}$} & $1 \mathrm{~m} / \mathrm{s}$ & 8.76 & 8.88 & \multirow{3}{*}{0.6143} \\
\hline & & $1.5 \mathrm{~m} / \mathrm{s}$ & 7.57 & 6.69 & \\
\hline & & $2 \mathrm{~m} / \mathrm{s}$ & 5.27 & 4.68 & \\
\hline \multirow{3}{*}{$\begin{array}{l}\text { Rotational air } \\
\text { flow }\end{array}$} & \multirow{3}{*}{$2 \mathrm{MW}$} & $1 \mathrm{~m} / \mathrm{s}$ & 7.26 & 7.82 & \multirow{3}{*}{0.6472} \\
\hline & & $1.5 \mathrm{~m} / \mathrm{s}$ & 6.58 & 6.00 & \\
\hline & & $2 \mathrm{~m} / \mathrm{s}$ & 5.07 & 4.29 & \\
\hline \multirow{3}{*}{$\begin{array}{l}\text { Rotational air } \\
\text { flow }\end{array}$} & \multirow{3}{*}{$5 \mathrm{MW}$} & $1 \mathrm{~m} / \mathrm{s}$ & 5.46 & 6.39 & \multirow{3}{*}{0.8506} \\
\hline & & $1.5 \mathrm{~m} / \mathrm{s}$ & 5.22 & 4.99 & \\
\hline & & $2 \mathrm{~m} / \mathrm{s}$ & 4.78 & 3.66 & \\
\hline
\end{tabular}




\section{Chapter 8: Design Guidelines}

\subsection{Design Recommendations}

Based on the results of the research reported earlier, the following procedure for calculating the smoke layer height is proposed:

1. Select a safe height for the smoke layer to ensure people on the highest floor will not be affected by the smoke in the event of a fire in the atrium (normally 2 $\mathrm{m}$ above the highest floor).

2. Select a design fire as required by the building codes.

3. Determine the opening area where the make-up air can enter into the atrium.

4. Calculate the exhaust rate for the smoke management system to maintain the smoke layer at the required height using the atrium correlations.

5. Calculate the make-up air velocity by dividing the exhaust rate by the opening area in the atrium.

6. Calculate the reduction factor from the proposed correlation for the design $Q_{c}$ and the calculated make-up air velocity from step 5 .

$$
R F=f_{r} f_{a}\left(\frac{1}{2.688 \dot{Q}_{c}^{\frac{1}{2}}} V^{3}-\frac{1}{1.2 \dot{Q}_{c}^{\frac{1}{3}}} V^{2}+\frac{1}{120} V+1\right)
$$

Where, 
$f_{a}$ is the opening arrangement factor and is equal to:

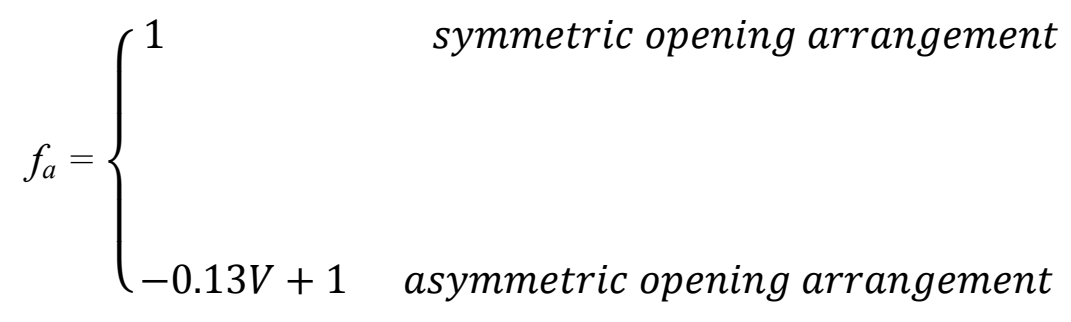

And $f_{r}$ is the rotational make-up air factor and is equal to:

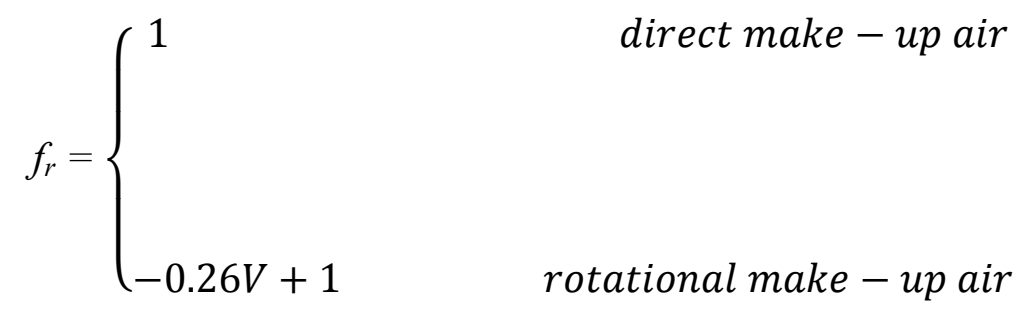

7. Multiply the calculated reduction factor to the estimated smoke layer height from the atrium correlations.

One of the $f_{a}$ and $f_{r}$ factors is always equals to 1.0 , as the case of rotational make-up air and the case of asymmetric opening arrangement will not occur simultaneously. 
The proposed reduction factor correlation provides more flexibility in the design of smoke management system by estimating the effect of higher make up air velocities on the smoke propagation in the atrium. The higher range of make-up air velocity will cover the air velocities higher than $1 \mathrm{~m} / \mathrm{s}$ which are prohibited by the existing regulations.

\subsection{Design Procedure}

Figure 8-1 illustrates the design flowchart for the smoke management system design. 


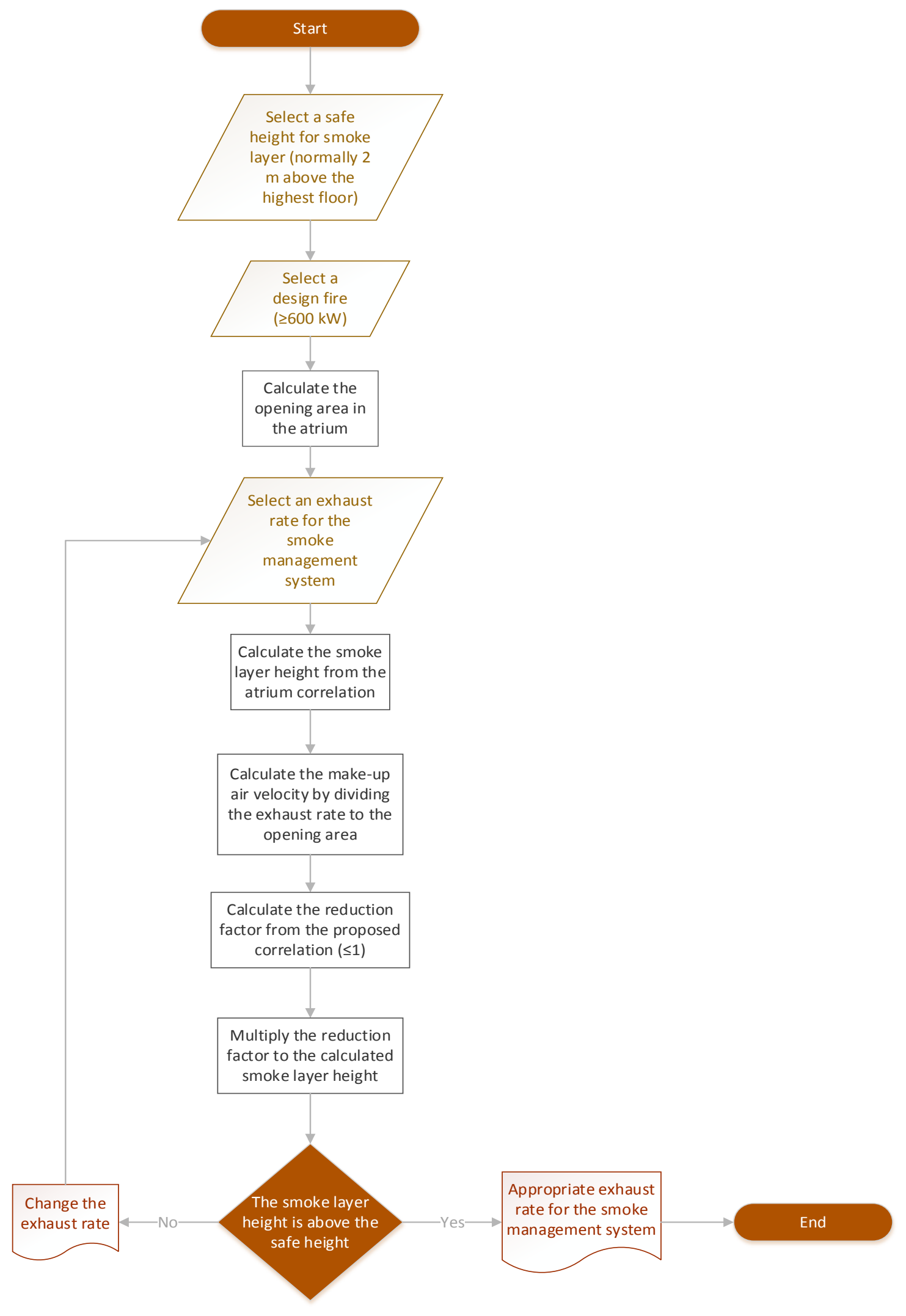

Figure 8-1 Design flowchart 
The following examples explain the design of smoke management system by using of atrium correlations and the proposed reduction factor.

\section{Example 1: Symmetric Opening Arrangement}

Design the smoke management system for a $30 \mathrm{~m}$ high atrium with the highest floor located at $22 \mathrm{~m}$. The atrium has $100 \mathrm{~m}^{2}$ opening area at the floor level and the design fire is assumed to be $2 \mathrm{MW}$. The convective heat release rate is $1.4 \mathrm{MW}$ assuming 0.7 for the convection factor from total heat release rate.

Since the highest floor is located at $22 \mathrm{~m}$, the minimum height for the smoke layer should be $24 \mathrm{~m}$ with respect to the $2 \mathrm{~m}$ height for the height of occupants in the highest floor.

The standards restrict the make-up air velocity to $1 \mathrm{~m} / \mathrm{s}$. Therefore the maximum exhaust rate for the smoke management system will be limited to $100 \mathrm{~m}^{3} / \mathrm{s}$. This exhaust rate cause the smoke layer to descend to $20.3 \mathrm{~m}$ in the atrium which is below the safe height at $24 \mathrm{~m}$.

\section{First try:}

Increasing the exhaust rate to $150 \mathrm{~m}^{3} / \mathrm{s}$ causes the smoke layer height to increase to 26 $\mathrm{m}$ based on the atrium correlations. Dividing this exhaust rate by the $100 \mathrm{~m}^{2}$ opening area results in a make-up air velocity of $1.5 \mathrm{~m} / \mathrm{s}$. The reduction factor from the 
correlations for the $1.4 \mathrm{MW}$ convective heat release rate and $1.5 \mathrm{~m} / \mathrm{s}$ air velocity is 0.88 . Multiplying the reduction factor to the estimated smoke layer height gives a smoke layer of $22.8 \mathrm{~m}$ which is still below the safe height.

\section{Second try:}

The exhaust rate of the smoke management system is increased to $180 \mathrm{~m}^{3} / \mathrm{s}$. Therefore the smoke layer increases to $29 \mathrm{~m}$ based on the atrium correlations. Dividing this exhaust rate by the $100 \mathrm{~m}^{2}$ opening area gives a make-up air velocity of $1.8 \mathrm{~m} / \mathrm{s}$. The reduction factor is now 0.83 for the $1.4 \mathrm{MW}$ convective heat release rate and $1.8 \mathrm{~m} / \mathrm{s}$ air velocity. Multiplying the reduction factor to $29 \mathrm{~m}$ decreases the smoke layer height to $24.2 \mathrm{~m}$ which is above the safe height.

\section{Example 2: Asymmetric Opening Arrangement}

Design the smoke management system for a $40 \mathrm{~m}$ high atrium with the highest floor located at $23 \mathrm{~m}$. The atrium has $190 \mathrm{~m}^{2}$ opening area at the floor level and the design fire is assumed to be $3 \mathrm{MW}$. The convective heat release rate is $2.1 \mathrm{MW}$ assuming 0.7 for the convection factor.

Since the highest floor is located at $23 \mathrm{~m}$, the minimum height for the smoke layer should be $25 \mathrm{~m}$.

The maximum exhaust rate for the smoke management system that will have a $1 \mathrm{~m} / \mathrm{s}$ make-up air velocity is $190 \mathrm{~m}^{3} / \mathrm{s}$. This flow rate gives a layer height of $27.6 \mathrm{~m}$ which is 
above the safe height. The reduction factor for the case of asymmetric opening arrangement is 0.82 for the $2.1 \mathrm{MW}$ convective heat release rate and $1 \mathrm{~m} / \mathrm{s}$ air velocity. Multiplying the reduction factor to the smoke layer height gives a smoke layer height of $22.8 \mathrm{~m}$ which is below the safe height at $25 \mathrm{~m}$.

\section{First try:}

Increasing the exhaust rate to $220 \mathrm{~m}^{3} / \mathrm{s}$ increases the smoke layer height to $30.2 \mathrm{~m}$ based on the atrium correlations, which results in a make-up air velocity of $1.15 \mathrm{~m} / \mathrm{s}$. The reduction factor for asymmetric opening arrangement is 0.79 for the $2.1 \mathrm{MW}$ convective heat release rate and $1.15 \mathrm{~m} / \mathrm{s}$ air velocity. Multiplying the reduction factor to the estimated smoke layer height, gives a smoke layer of $24 \mathrm{~m}$ which is still below the safe height.

\section{Second try:}

The exhaust rate of the smoke management system is increased to $320 \mathrm{~m}^{3} / \mathrm{s}$, which gives a smoke layer of $37.9 \mathrm{~m}$ and a make-up air velocity of $1.67 \mathrm{~m} / \mathrm{s}$. The reduction factor becomes 0.68 and the smoke layer height $25.7 \mathrm{~m}$ which is above the safe height.

Figure 8-2 shows the reduction factor graph for different fire sizes. These lines correspond to $600,1000,2500,5000$ and $10000 \mathrm{~kW}$ heat release rates. The lowest curve shows the reduction factor for the $600 \mathrm{~kW}$ fire, and the highest curve shows the reduction factor for the $10000 \mathrm{~kW}$ fire. 
Figure 8-2 shows that the effect of lower make-up air velocities with different fire sizes on the smoke conditions in symmetric opening arrangements is very small. For example, a $0.5 \mathrm{~m} / \mathrm{s}$ air velocity makes a very small change in the reduction factor of different fire sizes. Therefore the values of the reduction factor for different atrium fires exposed to make-up air velocities less than $1 \mathrm{~m} / \mathrm{s}$ in the case of symmetric opening arrangement is very close to 1.00 .

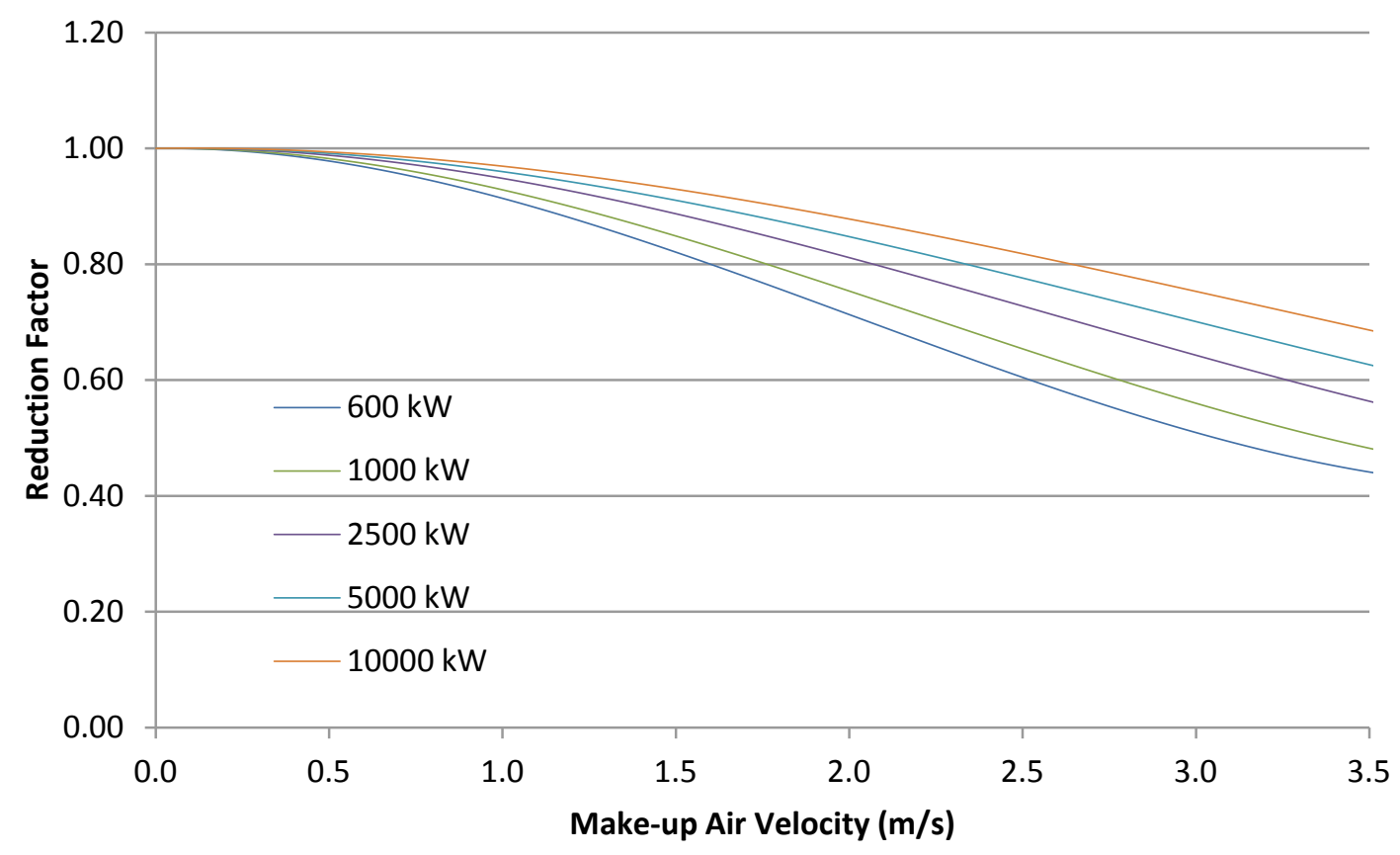

Figure 8-2 Proposed reduction factor graph for different fire sizes in symmetric opening arrangement

The proposed correlation is not valid for fires smaller than $600 \mathrm{~kW}$. Also make-up air velocities higher than $3.5 \mathrm{~m} / \mathrm{s}$ are strongly not recommended for a symmetric opening arrangement. 
Figure 8-3 shows the proposed reduction factor for the asymmetric opening arrangement corresponding $600 \mathrm{~kW}, 1000 \mathrm{~kW}, 2500 \mathrm{~kW}, 5000 \mathrm{~kW}$ and $10000 \mathrm{~kW}$ fire. The make-up air velocities higher than $3 \mathrm{~m} / \mathrm{s}$ are strongly not recommended in the case of asymmetric opening arrangement.

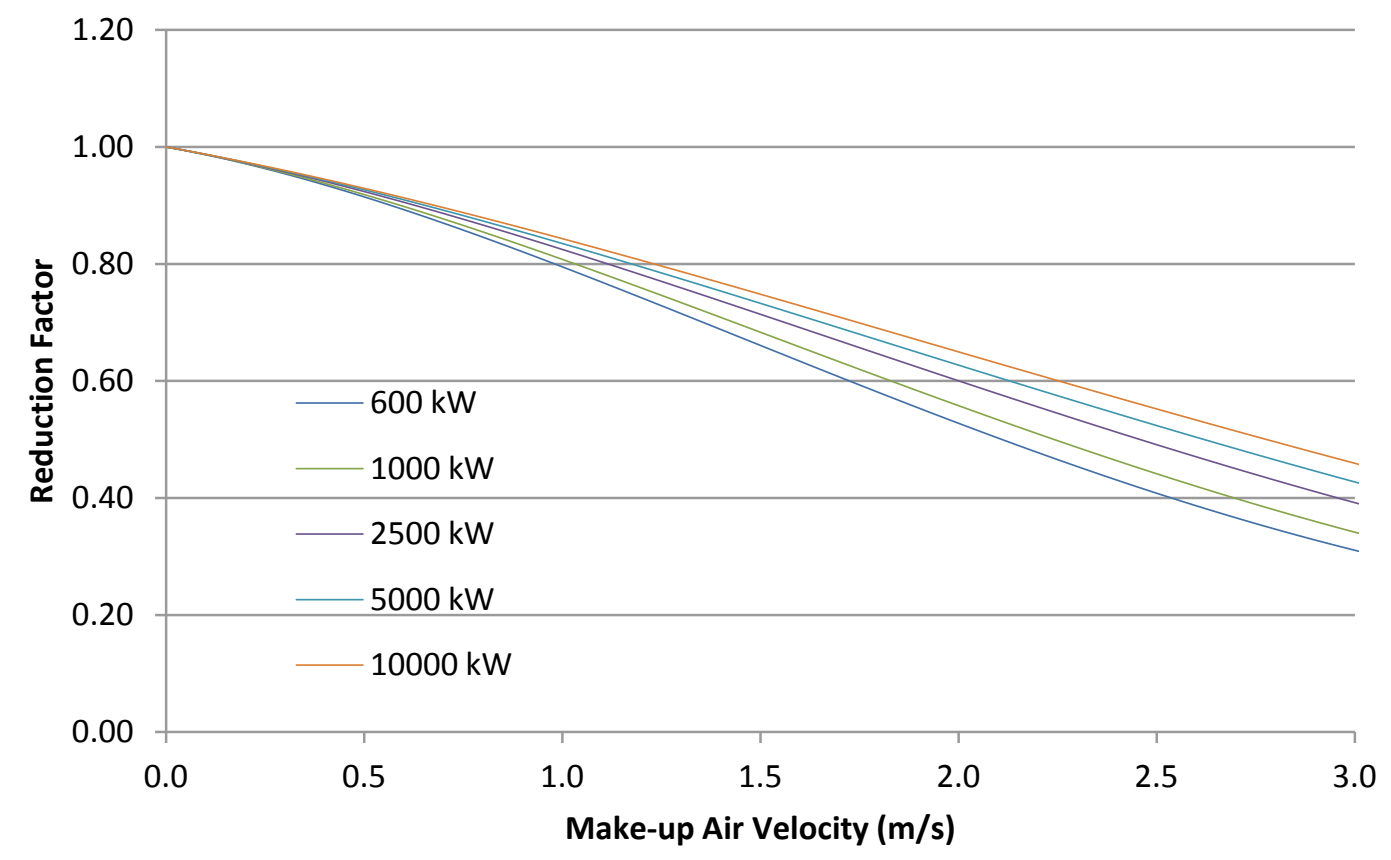

Figure 8-3 Proposed reduction factor graph for different fire sizes in asymmetric opening arrangement

Figure 8-4 shows the reduction factor correlation for atrium fires exposed to rotational make-up air. The reduction factor correlation is plotted for fires in the range of $600 \mathrm{~kW}$ to $10000 \mathrm{~kW}$. The reduction factor corresponding to $600 \mathrm{~kW}$ fire is the lowest line and the $10000 \mathrm{~kW}$ fire is the highest line in Figure 8-4. The make-up air velocities higher than $2 \mathrm{~m} / \mathrm{s}$ are strongly not recommended in case of rotational make-up air in the atrium. 


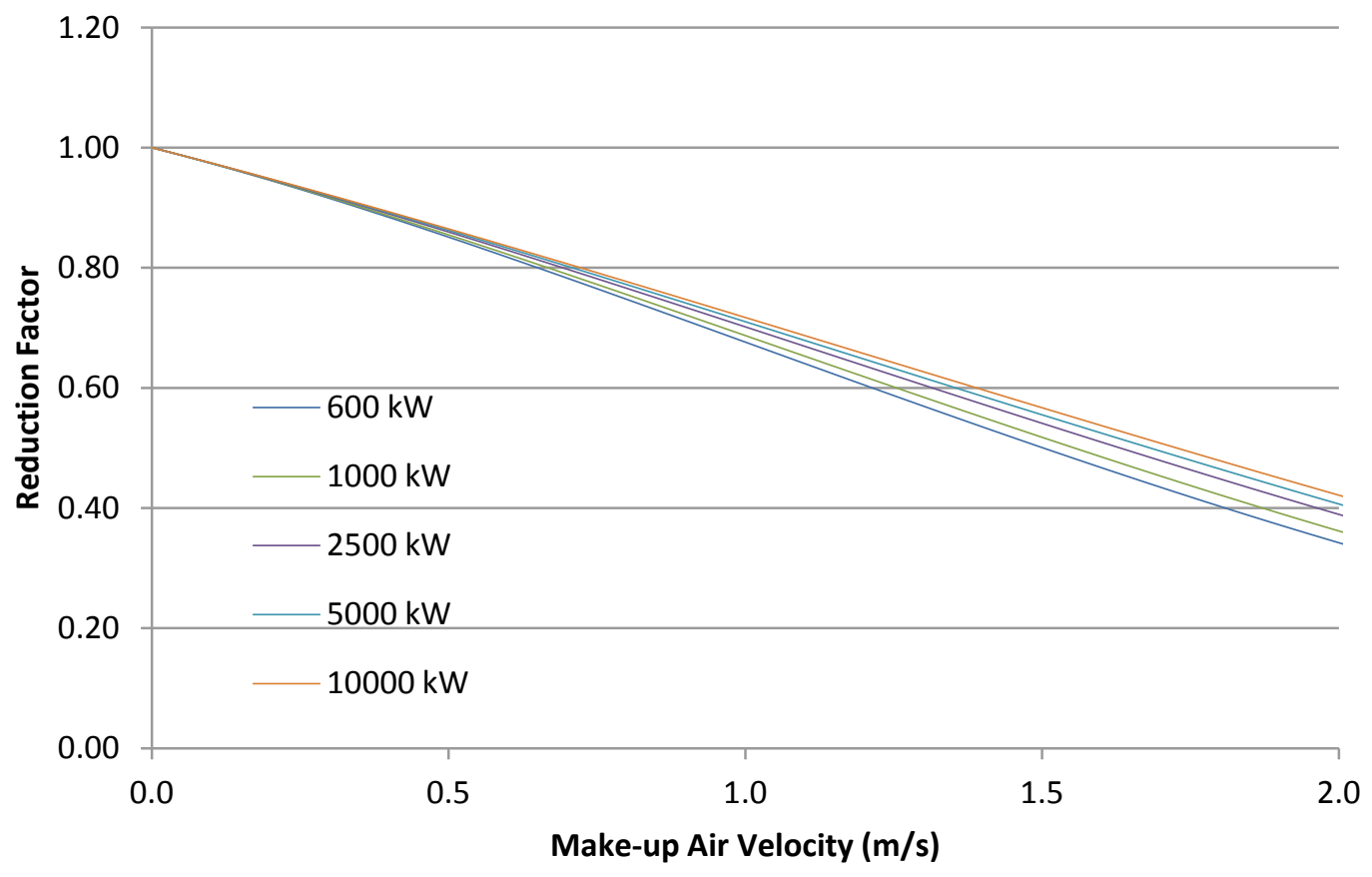

Figure 8-4 Proposed reduction factor graph for different fire sizes exposed to rotational make-up air velocity

According to Figures 8-2 to 8-4, the reduction factor decreases with increasing the make-up air velocity. Also, increasing the size of the fire results in an increase in the reduction factor. This is consistent with the theory of turbulence, as thick buoyant plumes caused by big fires are more resistant to be disturbed than thin plumes from small fires. In other words, the impact of make-up air velocity on the smoke conditions in the atrium decrease with increasing the fire size due to the increased thickness and buoyancy of fire plume.

In addition, a comparison between Figures 8-2 to 8-4 shows that the effect of fire size on the reduction factor correlation decreases by changing the symmetric opening arrangement to asymmetric opening arrangement and exposing the atrium fire to the 
rotational make-up air. In other words, the smoke and fire plume will be easily affected by the make-up air flow when the air flow is not symmetric and directed to the fire regardless of the fire size. 


\section{Chapter 9: Conclusions}

\subsection{Conclusion}

CFD modelling gives a good visual understanding and allows comparisons between different fire tests in the atrium but the predicted smoke layer height is lower than the one obtained from the experiments. The lower interface height predicted by the CFD model indicates that the simulation plume entrains more air, which also explains why the model predicts lower temperatures in the hot layer than the experiments and the correlations.

The atrium correlations predict the smoke layer height approximately close to the experimental values for the symmetric opening arrangement with direct air flow and not very high velocity in the atrium. Although, the make-up air velocity of $1 \mathrm{~m} / \mathrm{s}$ is not too restrictive, the air velocity of 1.5 might be acceptable depending on the other conditions in the atrium design such as the opening arrangement. The opening configuration is an essential input in the design of the atrium exhaust system as the asymmetric opening arrangement increases smoke turbulence and decreases the smoke layer height. In addition, it is pivotal to consider the air flow direction in the atrium, as rotational makeup air increases the smoke disturbance and causes a large descent of the smoke interface height.

The difference between the effects of make-up air on the smoke layer height between the 4-sides and 2-opposite sides symmetric opening arrangements is very small. Also, 
the change in the smoke layer height of the different types of asymmetric opening arrangements, which include 3-sides opening, 2-adjacent side opening and one side opening is negligible. However, the effect of changing the opening arrangement from symmetric to asymmetric opening arrangement is considerable. Based on a comparison between the results of symmetric and asymmetric opening arrangement, it is recommended to decrease the reduction factor by an additional factor, $f_{a}$, in the presence of asymmetric opening arrangement.

Locating openings at the corners of the atrium results in rotational make up air which increases the smoke disturbance in the atrium. A comparison between the results of the direct air flow and the results of rotational make-up air show that the rotational makeup air causes a big decrease of the smoke interface height. Therefore, it is recommended to reduce the proposed reduction factor to by an additional factor, $f_{r}$, in order to consider the effect of rotational make-up air.

The effect of opening distance to the fire has been studied indirectly, as the opening has been located at $8 \mathrm{~m}$ from the fire in the 1-side opening arrangement case in Chapter 6 and the tunnel was located at $5 \mathrm{~m}$ far from the fire in the Chapter 5 experiments and simulations. The results show that the impact of opening distance to the fire is not considerable when the air is blowing from one side of the opening. This result is consistent with the results of Zhou and Hadjisophocleous (2006). 
Theoretically, the impact of make-up air should decrease with increasing the opening distance to the fire in an atrium. However, the results show that for the short distances such as $2.5 \mathrm{~m}, 5 \mathrm{~m}$ and $8 \mathrm{~m}$ in a relatively small atrium and when the air is blowing from one side of the atrium, decreasing the distance of the opening to the fire causes relatively less turbulence than the turbulence caused by increasing the air velocity and changing the opening arrangement.

\subsection{Recommendations for Future Work}

In order to achieve an accurate reduction factor correlation, it is recommended to perform additional experiments and CFD modelling to consider several air velocities in the range of $0 \mathrm{~m} / \mathrm{s}$ to $4 \mathrm{~m} / \mathrm{s}$. Therefore, plotting a trend line with more points will result in an optimized correlation which will guarantee a safe and economical engineering tool for atrium designers.

The reduction factor correlation is proposed based on axisymmetric fire plumes. Therefore, there is still a need to conduct research for other types of plumes such as corner plume, balcony plume, window plume and etc. This research should include both CFD modelling and full-scale tests to validate the simulation results. Such research might update the proposed reduction factor correlation to consider the effect of other types of plumes. 
In order to investigate the effect of opening distance to the fire on the smoke conditions in the atrium, it is recommended to consider atria with several sizes of floor area. Also, it is recommended to consider the symmetric opening arrangement as well as the asymmetric opening arrangement in the evaluation of the opening distance to the fire. The best scenario might be to simulate an atrium fire which is fixed in the middle of the atrium and changing the size of floor area of the atrium. The experimental study of evaluating the effect of opening distance to the fire is very limited due to the availability of atria with different area section.

The height of the opening is not considered in the correlations and it does not theoretically have any effect on the smoke layer height. But, depending on the opening height, it may increase the smoke turbulence if the smoke descends to the opening height and mixes with the make-up air. In general, the best place for the opening is below the smoke interface height and ideally at the floor. In these series of tests, it was not possible to increase the size of the fire to more than $5 \mathrm{MW}$ and maintain the makeup air velocity at $1 \mathrm{~m} / \mathrm{s}$ due to the facility restrictions. Therefore, in order to perform CFD modelling, it is very important to consider a tall atrium which has enough height to evaluate the smoke layer decent without a direct effect of fresh air to the smoke layer. 


\section{References}

American Gas Association (AGA). (1974). LNG safety program interim report on phase II work. Report IS 3-1, Battelle Columbus Laboratories, Arlington, VA, July.

Ayala, P., Cantizano, A., Gutiérrez-Montes, C., \& Rein, G. (2013). Influence of atrium roof geometries on the numerical predictions of fire tests under natural ventilation conditions. Energy and Buildings, 65, 382-390.

Bukowski, R. W. (1991). Fire Models, the Future is Now. NFPA Journal, No. 85, Vol. 2, pp. 60-69.

Chow, W. K. (1993). Smoke Development and Engineering Aspects of Smoke Extraction Systems for Atria in Hong Kong. Fire and Materials, Vol. 17, pp. 71-77.

CIBSE. (1995). Relationships for Smoke Control Calculations. Technical Memoranda TM19:1995., London: Chartered Institute of Building Services Engineers.

Cooper, L. Y., Harkleloard, M., Quintiere, J. and Rinkinen, W. (1982). An Experimental Study of upper hot Layer Stratification in Full-scale Multi-room Fire Scenarios. Journal of Heat Transfer, Vol. 104, pp. 741-749.

Doheim, R. M., Yohanis, Y. G., Nadjai, A., \& Elkadi, H. (2014). The impact of atrium shape on natural smoke ventilation. Fire Safety Journal, 63, 9-16.

Forney, G. P. (2010). User's Guide for Smokeview (Version 5), National Institute of Standards and Technology, NIST, Special Publication 1017 1. Gaithersburg, MD.

Gutiérrez-Montes, C., Sanmiguel-Rojas, E., Viedma, A., \& Rein, G. (2009). Experimental data and numerical modelling of 1.3 and $2.3 \mathrm{MW}$ fires in a $20 \mathrm{~m}$ cubic atrium. Building and Environment, 44(9), 1827-1839. 
Hadjisophocleous, G. V. and McCartney, C. J. ( 2005). Guidelines for the use of CFD simulations for fire and smoke modeling, ASHRAE symposium paper, ASHRAE meeting, Denver.

Hadjisophocleous, G. V., Fu, Z. and Lougheed, G. (2002). Experimental Study and Zone Modeling of Smoke Movement in a Model Atrium, ASHRAE Transactions, 108, pt. 2, pp. $868-874$.

Hagglund, B. and Werling, P. (1985). Smoke Filling Experiments in a $6 \times 6 \times 6$ meter enclosure. National Defense Research Institute of Sweden.

Hansell, G. O. and Morgan, H. P. (1994). Design approaches for smoke control in atrium building, BR-258, Building Research Establishment, Garston, UK.

Heskestad, G. (1984). Engineering Relations for Fire Plumes, Fire Safety Journal, Vol. 7, pp. 25-32.

Heskestad, G. (1986). Fire Plume Air Entrainment According to Two Competing Assumptions, Twenty-first Symposium (International) on Combustion, Combustion Institute, Pittsburgh, Pa, pp.111-120.

Hinckley, P. L. (1995). Smoke and Heat Venting, SFPE Handbook of Fire Protection Engineering, National Fire Protection Association, Quincy, MA, pp. 3-160 to 3-173.

Janssens, M. and Tran, H. C. (1992). Data Reduction of Room Tests for Zone Model Validation, Journal of Fire Science, 10, No. 6, pp. 528-555.

Jones, W. W. (1983). A Review of Compartment Fire Models. Nat. Bur. Of Stand. (US), NBSIR 83-2684.

Kerber, S. and Milke, J. A. (2007). Using FDS to Simulate Smoke Layer Interface Height in a Simple Atrium, Fire Technology, 43, 45-75. 
Klote, J. H., Ferreira, M. J., Kashef, A., Turnbull, P. G., \& Milke, J. A. (2012). Handbook of smoke control engineering. American Society of Heating Refrigerating and Air-Conditioning Engineers.

LabVIEW 2012 user manual. (2012). National Instruments, Austin, Texas.

Law, M. (1986). A note on smoke plumes from fires in multi-level shopping malls. Fire Safety Journal 10:197.

Lougheed, G. D. (2000). Considerations in the Design of Smoke Management Systems for Atriums. Institute for Research in Construction, National Research Council of Canada, Ottawa, ON.

Lougheed, G. D. and Hadjisophocleous, G. V. (1997). Investigation of atrium smoke exhaust effectiveness, ASHRAE Transactions, Vol. 103, pt. 2, pp. 519-533.

Lougheed, G. D., Hadjisophocleous, G. V. and Cao, S. (1999). Numerical Study of the Effectiveness of Atrium Smoke Exhaust Systems, ASHRAE Transactions, Vol. 105, pt. 1, pp. 1-17.

Lougheed, G. D., Hadjisophocleous, G. V., McCartney, C. and Taber, B. C. (1999). Large-scale Physical Model Studies for an Atrium Smoke Exhaust System. ASHRAE Transactions, Vol. 105, pt. 1, pp. 676-698.

McGrattan, K. , Hostikka, S. , Floyd, J. , Baum, H. and Rehm, R. (2007). Fire Dynamic Simulator (version 5) Technical reference guide. National Institute of Standard and Technology.

McGrattan, K., McDermott, R., Hostikkia, S. and Floyd, J. (2010). Fire Dynamics Simulator (Version 5) User's Guide, NIST Special Publication 1019-5, National Institute of Technology and Standards, Gaithersburg. 
Mudan, K. S. and Croce P. A. (2002). Fire hazard calculation for large open hydrocarbon fires. SFPE Handbook of Fire Protection Engineering, NFPA, Quincy, MA, pp. 3-71.

Mudan, K. S. and Croce, P. A. (1998). Fire hazard calculation for large open hydrocarbon fires, SFPE Handbook of Fire Protection Engineering, NFPA, Quincy, MA.

Mudan, K. S., and Croce, P. A. (1995). Fire Hazard Calculations for large Open Hydrocarbon Fires, The SFPE Handbook of Fire Protection Engineering ( $2^{\text {nd }}$ ed.), P.J. DiNenno (ed.), national Fire Protection Association, Quincy, MA, Vol. 3, pp. 197- 240. Mulholland, G., Handa, T., Sugawa, O., and Yamamoto, H. (1981). Smoke filling in an enclosure. Fire Science and Technology, 1(1), pp. 1-31.

NFPA 92B. (2009). Guide for smoke management systems in malls, atria and large areas, NFPA, National Fire Protection Association, Quincy, MA.

Nowler, S. P. (1987). Enclosure Environment Characterization Testing for the Baseline Validation of Computer Fire Simulation Codes. Sandia National Laboratories.

Souza, V. T. D. (2004). and Milke J.A., Modeling smoke layer interface height as a function of make-up air supply velocity for atrium design. Fire safety Journal 6.

Thomas, P. H. (1962). The Size of Flame from Natural Fires, $9^{\text {th }}$ Symposium (International) on Combustion, The Combustion Institute, Pittsburgh, pp. 844-859.

W. K. Chow. (2009). Determination of the Smoke Layer Interface Height for Hot Smoke Tests in Big Halls, Journal of Fire Science, VOL. 27.

Wong, L.T. (2001). Scale Modeling Studies of Smoke Filling. International Journal on Engineering Performance-Base Fire Codes, No. 3, Vol. 3, pp.118-127. 
Yi, L., Chow, W.K., Li, Y.Z. and Huo, R. (2004). A Sample Two-layer Zone Model on Mechanical Exhaust in an Atrium. Building and Environment, Vol. 8.

Zhou, J. (2006). Evaluation of Atrium Smoke Exhaust Make-up Air Velocity, Civil Engineering Department, Carleton University, Ottawa, ON.

Zukoski, E. E. (1995). Properties of Fire Plumes, Combustion Fundamentals of Fire, Cox, G., ED., Academic Press, London. 